\title{
Idaho National Engineering and Environmental Laboratory Site Environmental Report for Calendar Year 1998
}

Troy R. Saffle

Russell $G$. Mitchell
Roy B. Evans

Don B. Martin

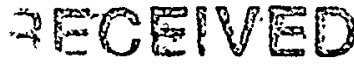

DEC 272000

OSTI

Environmental Science and Research Foundation, Inc.

Doyle Markham, Executive Director

Betsy Jonker

U.S. Department of Energy-ldaho Operations Office

July 2000

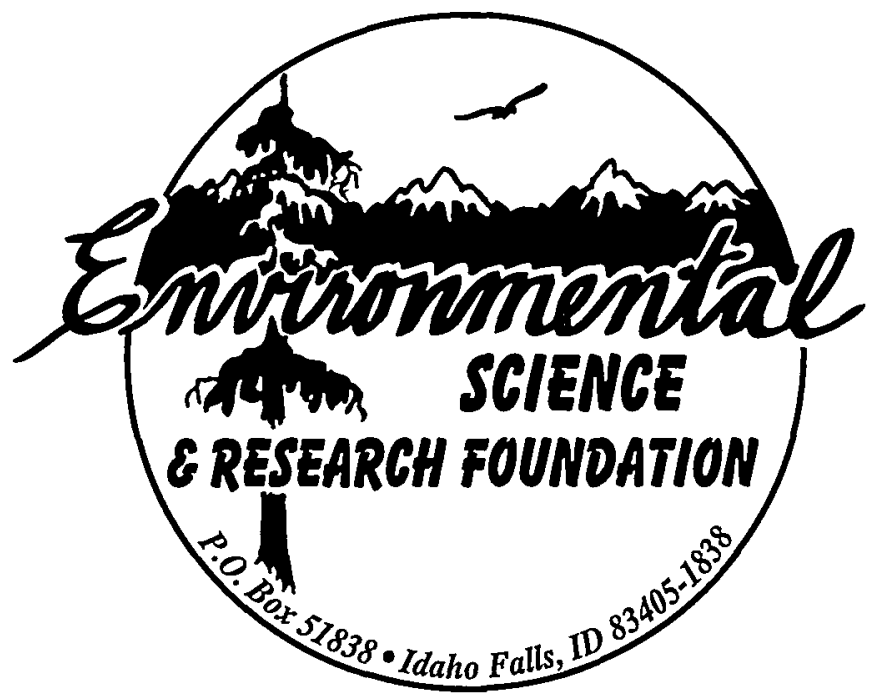

Report was prepared for the U.S. Department of Energy-Idaho Operations Office under Contract DE-AC07-94ID13268 by the

Environmental Science and Research Foundation, Inc.

101 S. Park Avenue, Suite 2; PO Box 51838

Idaho Falls, Idaho 83405-1838 


\section{U.S. Department of Energy \\ Idaho National Engineering and Environmental Laboratory \\ June, 1998}

Environmental Policy

The mission of the INEEL as a national laboratory has always necessitated a partnership between our work and our environmental surroundings. As such, we are both a National Laboratory and a National Research Park. The 890 square miles of unique ecosystem that is home to the INEEL has been kept relatively undeveloped and unoccupied throughout our history. These conditions have provided an opportunity to maintain the quality of this unique ecosystem while conducting valuable scientific research in both energy and environmental areas.

In continuing this legacy, it is the policy of the INEEL that:

\section{We conduct business and operations in a manner that protects human health and the environment and complies with environmental laws and regulations.}

In support of this policy we:

- $\quad$ Develop, use, and refine environmental management systems for the planning and execution of work.

- $\quad$ Establish documented environmental objectives and targets, and update them as necessary to reflect the changing needs, missions, and goals of the INEEL.

- Continuously improve our activities through critical self-assessment and corrective action.

- $\quad$ Conduct our operations in full compliance with applicable laws, codes and regulations.

- $\quad$ Reduce environmental impacts, costs and compliance liabilities through pollution prevention and recycling.

- $\quad$ Ensure all employees understand the environmental impacts of their work.

- Work openly with regulators and stakeholders to build and maintain an atmosphere of trust.

- $\quad$ Care for the natural resources of the INEEL.

This policy was developed and issued jointly by the Department of Energy field elements for the Idaho National Engineering and Environmental Laboratory. 


\section{DISCLAIMER}

This report was prepared as an account of work sponsored by an agency of the United States Government. Neither the United States Government nor any agency thereof, nor any of their employees, make any warranty, express or implied, or assumes any legal liability or responsibility for the accuracy, completeness, or usefulness of any information, apparatus, product, or process disclosed, or represents that its use would not infringe privately owned rights. Reference herein to any specific commercial product, process, or service by trade name, trademark, manufacturer, or otherwise does not necessarily constitute or imply its endorsement, recommendation, or favoring by the United States Government or any agency thereof. The views and opinions of authors expressed herein do not necessarily state or reflect those of the United States Government or any agency thereof. 


\section{DISCLAIMER}

Portions of this document may be illegible in electronic image products. Images are produced from the best available original document. 



\section{Preface}

Every person in the world is exposed to ionizing radiation - radiant energy that produces ions as it passes through cells. There are three general types of radiation sources: those of natural origin unaffected by human activities, those of natural origin but enhanced by human activities, and those produced by human activities (anthropogenic).

The first group includes terrestrial radiation from natural radiation sources in the ground, cosmic radiation from outer space, and radiation from radionuclides naturally present in the body. Exposures to natural sources may vary depending on the geographical location, and even the altitude, at which a person resides. When such exposures are substantially higher than the average, they are considered to be elevated.

The second group includes a variety of natural sources from which the radiation has been increased by human actions. For example, radon exposures in a given home may be elevated because of natural radionuclides in the soil and rock on which the house is built; however, the radon exposures of occupants may be enhanced by characteristics of the home, such as extensive insulation. Another example is the increased exposure to cosmic radiation that airplane passengers receive when traveling at high altitudes.

The third group includes a variety of exposures from human-made materials and devices such as medical $x$-rays, radiopharmaceuticals used to diagnose and treat disease, and consumer products containing minute quantities of radioactive materials. Exposures may also result from radioactive fallout from nuclear weapons testing, accidents at nuclear power plants, and other such episodic events caused by human activities in the nuclear industry. Except for major nuclear accidents, such as the one that occurred at Chernobyl in 1986, exposures to workers and members of the public from activities at nuclear industries are very small compared to exposures from natural sources [Reference P-1].

To verify that exposures resulting from operations at Department of Energy (DOE) nuclear facilities remain very small, each site at which nuclear activities are conducted operates an environmental surveillance program to monitor the air, water, and any other pathway whereby radionuclides from operations might conceivably reach workers and members of the public. Environmental surveillance and monitoring results are reported annually to DOE's headquarters.

This report presents a compilation of data collected in 1998 for the routine environmental surveillance programs conducted on and around the DOE's Idaho National Engineering and Environmental Laboratory (INEEL). During 1998, the offsite surveillance program was conducted by the Environmental Science and Research Foundation. Onsite surveillance was performed by the INEEL management and operations contractor (Lockheed Martin Idaho Technologies Company during the period of this report, referred to below as the M\&O contractor). Effluent monitoring and facility monitoring were conducted by the contractor responsible for operating each facility. The U.S. Geological Survey performed groundwater monitoring both on and offsite, and the INEEL M\&O contractor conducted facility and onsite ground-water monitoring. Air pathways were characterized by the National Oceanic and Atmospheric Administration.

This report, prepared in accordance with the requirements in DOE Order 5400.1, is not intended to cover the numerous special environmental research programs being conducted at the INEEL by the Environmental Science and Research Foundation, the INEEL M\&O contractor, the U. S. Geological Survey, and others [Reference P-2]. 
Section 9.g of DOE Order 5400.1 exempts the Naval Nuclear Propulsion Program's Naval Reactors Facility (NRF) from the provisions of this order and preparation of the Annual Site Environmental Report. The Naval Nuclear Propulsion Program separately maintains an environmental protection program to assure compliance with all applicable environmental laws and regulations. Monitoring data and information specific to NRF are provided in a separate annual environmental report issued by NRF. For completeness, however, some infor- mation from onsite monitoring programs at NRF is included in this report.

The Idaho National Engineering and Environmental Laboratory Site Environmental Report for Calendar Year 1998 was prepared by the Environmental Science and Research Foundation under DOE Contract DE-ACO794ID13268. Funding for this contract was provided by the Department of Energy Idaho Operations Office, with additional support provided by Argonne National Laboratory-West. 


\section{Executive Summary}

The results of the various monitoring programs for 1998 indicated that radioactivity from the DOE's Idaho National Engineering and Environmental Laboratory (INEEL) operations could generally not be distinguished from worldwide fallout and natural radioactivity in the region surrounding the INEEL. Although some radioactive materials were discharged during INEEL operations, concentrations in the offsite environment and doses to the surrounding population were far less than state of Idaho and federal health protection guidelines.

Chapter 2 of the report summarizes INEEL activities related to compliance with environmental regulations and laws, describes various environmental issues and activities, and summarizes INEEL permits for 1998 . Chapter 3 provides a description of major activities and milestones in waste management, environmental restoration, and other environmental programs.

Chapter 4 discusses results from radiological environmental surveillance programs conducted by the Environmental Science and Research Foundation (an independent nonprofit organization), and the INEEL's management and operations contractor. As part of these programs, samples of air, water, and foodstuffs were collected at distant locations, INEEL boundary locations and onsite locations. Environmental radiation measurements were also made at these locations.

Gross alpha and gross beta measurements, used as a screening technique for air filters, were investigated by making statistical comparisons between onsite or boundary location concentrations and the distant community group concentrations. Gross alpha activities were generally higher at distant locations than at boundary and onsite locations.

Foundation data indicated statistically significant differences in gross beta activities in 11 percent of comparisons of monthly means of onsite locations with the monthly distant group means. Comparisons of monthly mean gross beta activities measured onsite by the INEEL M\&O contractor with the monthly means measured by the INEEL M\&O contractor at distant locations found statistically significant differences in 10 percent of cases. At least some of these statistical differences may have been related to operations at the INEEL, but no source could be identified.

Air samples were also analyzed for specific radionuclides. Some human-made radionuclides were detected at offsite locations, but most were near the minimum detectable concentration and their presence was attributable to natural sources, worldwide fallout, and statistical variations in the analytical results rather than to INEEL operations.

The annual concentrations of all specific nuclides detected at all locations were well below the DOE's derived concentration guides for radiation protection.

Tritium was detected in some atmospheric moisture and precipitation samples, but concentrations were similar at distant, boundary, and onsite locations indicating that these detections were likely due to natural production in the upper atmosphere rather than to INEEL activities.

Gross alpha and gross beta activities were measured in offsite drinking and surface water samples. Concentrations were within the range expected for natural radioactivity. One offsite water sample contained a tritium concentration just above the minimum detectable concentration, attributable to fallout sources or statistical variations in the analytical results.

No milk samples contained ${ }^{131}$. Tritium was not detected in any milk sample in 1998. Seven samples contained detectable concentrations of ${ }^{90} \mathrm{Sr}$. These concentrations were consistent with levels seen in samples nationwide, 
as reported by the Environmental Protection Agency (EPA). Some food samples (lettuce, wheat, and potatoes) contained small amounts of ${ }^{137} \mathrm{Cs}$ and ${ }^{90} \mathrm{Sr}$, two radionuclides deposited by worldwide fallout which are found in soil.

Low concentrations of ${ }^{137} \mathrm{Cs}$ were found in muscle tissue and liver of some game animals and sheep. These levels were mostly consistent with background concentrations measured in animals sampled onsite and offsite in recent years. Anthropogenic radionuclides were also found in above-background concentrations in waterfowl and doves collected near the Test Reactor Area and in marmots collected near the RWMC. The potential dose to a hunter consuming game with the highest concentration of radionuclides was calculated to be approximately 0.03 mrem.

lonizing radiation) measured simultaneously at the INEEL boundary and distant locations using environmental dosimeters were similar and showed only background levels.

Both the Environmental Science and Research Foundation and the INEEL M\&O contractor also perform environmental surveillance for nonradiological substances. Chapter 5 presents a summary of air and storm water sampling results from the INEEL and offsite locations.

As in most previous years, total suspended particulate concentrations in air were generally higher at distant and boundary locations than at onsite locations. Agricultural activities are generally considered to be the major source of particulates in eastern Idaho. Annual onsite particulate concentrations were lower than in other recent years.

Fine particulates, nitrogen dioxide, and sulfur dioxide measured on and in the vicinity of the INEEL were all well within air quality standards. Levels of one or more parameters in storm water were above the corresponding EPA benchmarks at three monitoring points. How- ever, no storm water discharge from INEEL facilities reached any permanent surface streams.

Ground-water monitoring was performed at the INEEL by the USGS using over 125 wells that tap the Snake River Plain Aquifer, as described in Chapter 6. Results of a number of special studies of the properties of the aquifer and the water within it were published during 1998. Several purgeable organic compounds (POCs) continue to be found in wells at the INEEL. One well used for drinking water contained POCs. At all but two wells, concentrations of organic compounds were below the USEPA maximum contaminant levels (MCLs) for these compounds. In one production well at the Radioactive Waste Management Complex (RWMC), concentrations of carbon tetrachloride slightly exceeded the MCL. At one USGS monitoring well (not used for drinking water) concentrations of four POCs exceeded the corresponding MCLs. (Throughout this report, measured concentrations of contaminants in ground water and surface water are compared to the corresponding USEPA drinking water standards as benchmarks. The EPA drinking water MCLs apply only to water being consumed by at least 25 people on a non-transient basis. For any other water source, the MCLs are cited for comparison purposes only).

Routine monitoring of ground water was also conducted by contractors operating facilities at the INEEL. An effective dose equivalent of 0.5 $\mathrm{mrem} / \mathrm{yr}, 13$ percent of the EPA standard for community drinking water, was calculated for INEEL workers at the Central Facilities Area, the location with the highest tritium concentration in drinking water. Production wells in the vicinity of the Idaho Nuclear Technology and Engineering Center (formerly the Idaho Chemical Processing Plant) did not contain detectable levels of ${ }^{90} \mathrm{Sr}$ in 1998.

Water samples, taken from the wellhead at one Test Area North (TAN) well in 1987, showed purgeable organic compounds were above the maximum contaminant level for trichlorethylene. 
An aerating system known as a sparger was subsequently installed at TAN to volatilize the trichloroethylene and remove it prior to the water entering the distribution system. This has resulted in concentrations of organic compounds remaining less than drinking water standards in the distribution system.

Chapter 7 presents a description of the monitoring of airborne and liquid effluents released from INEEL facilities during 1998. An estimated total of 5,995 curies of radioactivity, primarily in the form of noble gases, were released as airborne effluents. Approximately 79 curies of radioactivity, mostly tritium, were released to onsite disposal ponds during the year.

Non-radiological pollutants, including sulfur and nitrogen dioxide were monitored at INEEL facilities. Nitrogen dioxide and sulfur dioxide concentrations, calculated for the INEEL boundary using meteorological models and measured at onsite locations, were well below air quality regulatory limits. Monitoring of liquid effluent streams indicated all were below applicable guidelines.

Chapter 8 describes the potential dose to members of the public from INEEL activities. The calculated hypothetical maximum individual effective dose equivalent of 0.008 mrem $\left(8 \times 10^{-5} \mathrm{mSv}\right)$ was found to occur near Mud Lake, Idaho. This calculation was performed with MDIFF, a computer model developed to evaluate dispersion of pollutants from INEEL facilities. The calculation considered continuous submersion in and inhalation of radioactivity in air, ingestion of radioactivity in leafy vegetables and milk, and exposure to radioactive particulates deposited on the ground surface at that location on a continuous, year-round basis. This calculated dose is about 0.002 percent of the background radiation dose in this area from all sources, including cosmic radiation, radioactive material in soil, natural radioactive potassium in the body, and exposure to radon.
The 1998 effective dose equivalent to the maximally exposed individual, calculated using the CAP-88 computer code required for demonstration of compliance with EPA regulations, was 0.007 mrem (0.002 percent of background). The model predicted the maximally exposed individual resided at Frenchman's Cabin, located at the INEEL's southern boundary. This location is currently inhabited only during portions of the year. The section entitled "Maximum Individual Dose - Airborne Emissions Pathway" includes a discussion of the two different computer models used. The maximum calculated dose to an individual by either of the methods was in compliance with the applicable radiation protection standards of 10 mrem per year.

The maximum potential population dose from submersion, ingestion, inhalation; and deposition to the approximately 121,500 people residing within an $80-\mathrm{km}(50-\mathrm{mi})$ radius from the geographical center of the INEEL was estimated to be 0.08 person-rem $\left(8 \times 10^{-4}\right.$ personSv) using the MDIFF air dispersion model. This population dose is less than 0.0002 percent of the estimated 43,700 person-rem (437 personSv) population dose from background radioactivity.

In Chapter 9, the methods used to ensure the quality of data generated by contractors performing environmental monitoring at the INEEL are described. Data from quality control samples, including duplicate samples (two similar samples collected at the same time) and spiked samples (samples containing a known amount of a contaminant) are provided. Comparisons are also provided between data collected by the Environmental Science and Research Foundation, the INEEL M\&O contractor, and the state of Idaho INEEL Oversight Program at locations where the three groups conduct similar sampling. 


\section{Helpful Information}

\section{Scientific Notation}

Scientific notation is used to express numbers which are very small and very large. A very small number will be expressed with a negative exponent, for example, $1.3 \times 10^{-6}$. To convert this number to the more commonly used form, the decimal point must be moved left by the number of places equal to the exponent $(6$, in this case). The number thus becomes 0.0000013 .

For large numbers, those with a positive exponent, the decimal point is moved to the right by the number of places equal to the exponent. The number $1,000,000$ (or one million) can be written as $1.0 \times 10^{6}$.

\section{Unit Prefixes}

Units for very small and very large numbers are commonly expressed with a prefix. One example is the prefix kilo (abbreviated $\mathrm{k}$ ), which means 1,000 of a given unit. A kilometer is therefore equal to 1,000 meters. Other prefixes used in this report are: radium-226, of which one gram decays at the rate of 37 billion nuclear disintegrations per second. For any other radionuclide, one curie is the amount of the radionuclide that decays at this same rate.

Radiation exposure is expressed in terms of the Roentgen $(R)$, the amount of ionization produced by gamma radiation in air. Dose is given in units of "Roentgen equivalent man" or rem, which takes into account the effect of radiation on tissues. For the types of environmental radiation generally encountered, the unit of Roentgen is approximately numerically equal to the unit of rem. A person-rem is the sum of the doses received by all individuals in a population.

Concentration of radioactivity in air samples and liquid samples such as water and milk is expressed in units of microcuries per milliliter $(\mu \mathrm{Ci} / \mathrm{mL})$ of air or liquid. Radioactivity in foodstuffs is expressed in microcuries per gram $(\mu \mathrm{Ci} / \mathrm{g})$. Annual human radiation exposure, measured by environmental dosimeters, is expressed in units of milliRoentgens (mR). This is sometimes expressed in terms of dose as

\begin{tabular}{|ccc|}
\hline & \multicolumn{2}{c|}{ Unit Prefixes Used in this Report } \\
Prefix & Abbreviation & Meaning \\
Mega- & $M$ & $1,000,000\left(=1 \times 10^{6}\right)$ \\
centi- & $\mathrm{c}$ & $1 / 100\left(=1 \times 10^{-2}\right)$ \\
milli- & $\mathrm{m}$ & $1 / 1,000\left(=1 \times 10^{-3}\right)$ \\
micro- & $\mu$ & $1 / 1,000,000\left(=1 \times 10^{-6}\right)$ \\
nano- & $\mathrm{n}$ & $1 / 1,000,000,000\left(=1 \times 10^{-9}\right)$ \\
pico- & $\mathrm{p}$ & $1 / 1,000,000,000,000\left(=1 \times 10^{-12}\right)$ \\
\hline
\end{tabular}

\section{Units of Radioactivity, Radiation Exposure and Dose}

The basic unit of radioactivity used in this report is the curie (abbreviated $\mathrm{Ci}$ ). The curie was historically based on the radionuclide millirem (mrem), after being multiplied by an appropriate dose equivalent conversion factor.

The Système International is also used to express units of radioactivity and radiation dose. The basic unit of radioactivity is the Becquerel $(\mathrm{Bq})$, which is equivalent to one nuclear disintegration per second. The number of curies must be multiplied by $3.7 \times 10^{10}$ to obtain the equivalent number of Becquerels. Doses may also be expressed using the Système International unit Sievert (Sv), where 1 Sievert equals 100 rem. 


\section{Uncertainty of Measurements}

There is always an uncertainty associated with the measurement of environmental contaminants. For radioactivity, the predominant source of uncertainty is the inherent statistical nature of radioactive decay events, particularly at the low activity levels encountered in environmental samples. The uncertainty of a measurement is denoted by following the result with a " \pm " (uncertainty) term. This report follows convention in reporting the uncertainty as a 95 percent confidence limit (or interval). That means there is about 95 percent confidence that the real concentration in the sample lies somewhere between the measured concentration minus the uncertainty term and the measured concentration plus the uncertainty term.

\section{Negative Numbers as Results}

Negative values occur when the measured result is less than a preestablished average background level for the particular counting system and procedure used. These values are reported as negative, rather than as "not detectable" or "zero," are reported to better enable statistical analyses and observe trends or bias in the data.

\section{Radionuclide Nomenclature}

Radionuclides are frequently expressed with the one- or two-letter chemical symbol for the element. Radionuclides may have many different isotopes, which are shown by a superscript to the left of the symbol. This number is the atomic weight of the isotope (the number of protons and neutrons in the nucleus of the atom). Radionuclide symbols used in this report are shown in the following table.

\section{Radionuclide \\ Tritium \\ Beryllium-7 \\ Carbon-14}

Radionuclide

Sodium-24

Potassium-40

Argon-41

Scandium-46

Chromium-51

Manganese-54

Iron-55

Manganese-56

Cobalt-57

Cobalt-58

Iron-59

Cobalt-60

Zinc-65

Krypton-85

Krypton-87

Krypton-88

Rubidium-88

Strontium-90

Yttrium-90

Niobium-94

Niobium-95

Zirconium-95

Technetium-99

Ruthenium-103

Ruthenium-106

Antimony-125

lodine-129

lodine-131

lodine-132

lodine-133

Xenon-133

Cesium-134

Xenon-135

Cesium-137

Cesium-138

Xenon-138

Barium-140

Cerium-144

Europium-152

Hafnium-181

Radium-226

Radium-228

Thorium-232

Uranium-234

Uranium-238
Symbol

${ }^{24} \mathrm{Na}$

${ }^{40} \mathrm{~K}$

${ }^{41} \mathrm{Ar}$

${ }^{46} \mathrm{SC}$

${ }^{51} \mathrm{Cr}$

${ }^{54} \mathrm{Mn}$

${ }^{55} \mathrm{Fe}$

${ }^{56} \mathrm{Mn}$

${ }^{57} \mathrm{Co}$

${ }^{58} \mathrm{Co}$

${ }^{59} \mathrm{Fe}$

${ }^{60} \mathrm{Co}$

${ }^{65} \mathrm{Zn}$

${ }^{85} \mathrm{Kr}$

${ }^{87} \mathrm{Kr}$

${ }^{88} \mathrm{Kr}$

${ }^{88} \mathrm{Rb}$

${ }^{90} \mathrm{Sr}$

${ }^{90} \mathrm{Y}$

${ }^{94} \mathrm{Nb}$

${ }^{95} \mathrm{Nb}$

${ }^{95} \mathrm{Zr}$

${ }^{99} \mathrm{Tc}$

${ }^{103} \mathrm{Ru}$

${ }^{106} \mathrm{Ru}$

${ }^{125} \mathrm{Sb}$

129

131 |

132

${ }^{133} \mathrm{I}$

${ }^{134} \mathrm{Cs}$

${ }^{135} \mathrm{Xe}$

${ }^{137} \mathrm{Cs}$

${ }^{138} \mathrm{Cs}$

${ }^{138} \mathrm{Xe}$

${ }^{140} \mathrm{Ba}$

${ }^{144} \mathrm{Ce}$

${ }^{152} \mathrm{Eu}$

${ }^{181} \mathrm{Hf}$

${ }^{226} \mathrm{Ra}$

${ }^{228} \mathrm{Ra}$

${ }^{232} \mathrm{Th}$

${ }^{234} U$

${ }^{238} \mathrm{U}$ 


\section{Radionuclide}

Plutonium-238

Plutonium-239/240

Americium-241

Curium-244

Symbol

${ }^{238} \mathrm{Pu}$

${ }^{239 / 240} \mathrm{Pu}$

${ }^{241} \mathrm{Am}$

${ }^{244} \mathrm{Cm}$ 


\section{Acronyms}

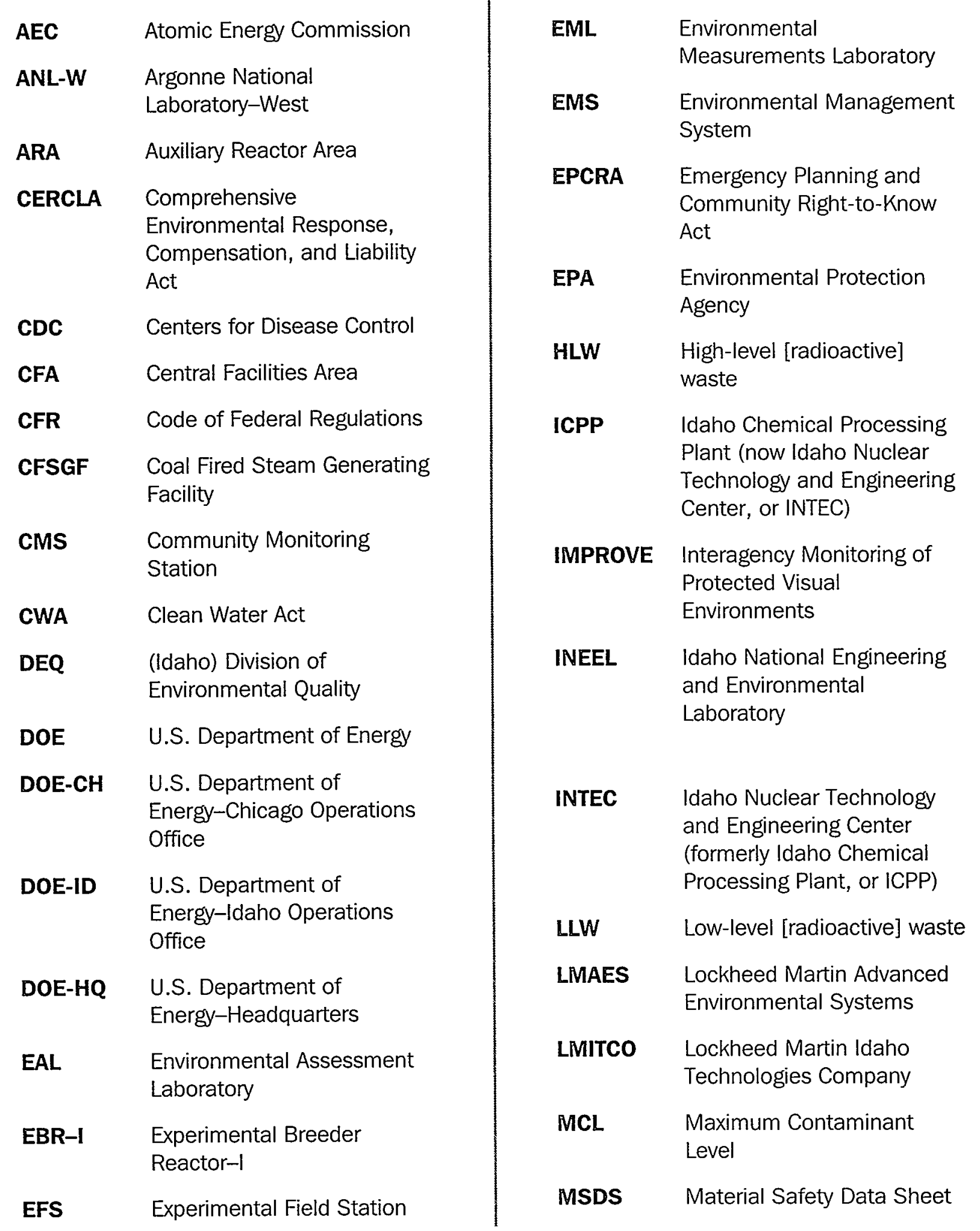




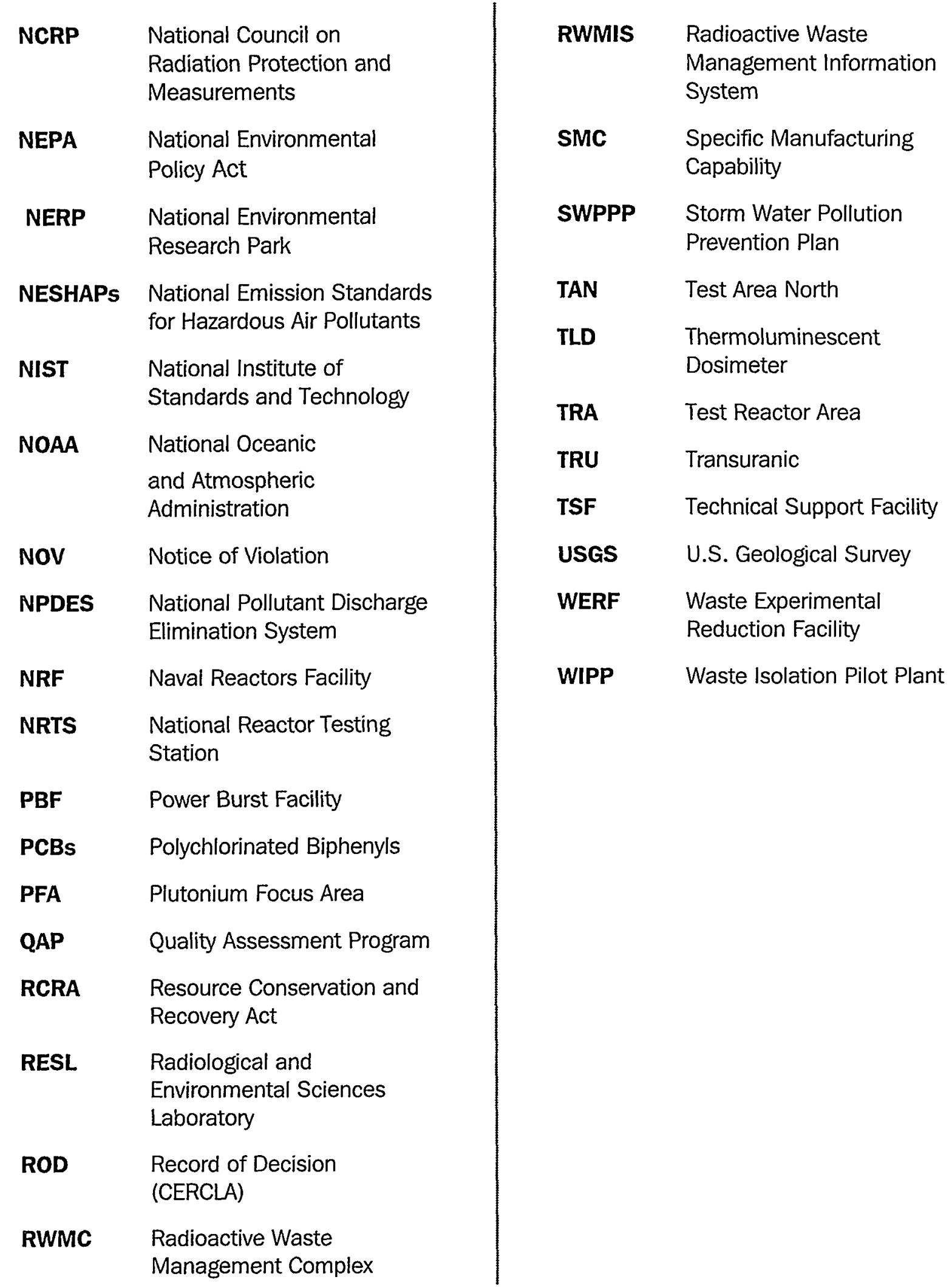




\section{Contents}

INEEL Environmental Policy $\ldots \ldots \ldots \ldots \ldots \ldots \ldots \ldots \ldots \ldots \ldots \ldots \ldots$ ii

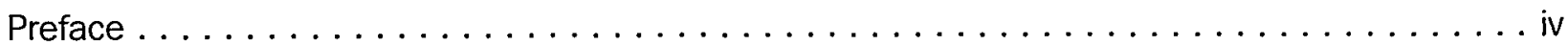

Executive Summary $\ldots \ldots \ldots \ldots \ldots \ldots \ldots \ldots \ldots \ldots \ldots \ldots \ldots \ldots \ldots \ldots$

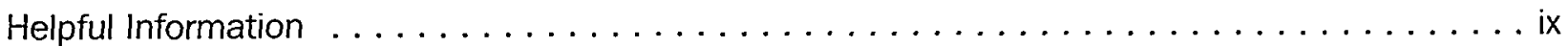

Acronyms $\ldots \ldots \ldots \ldots \ldots \ldots \ldots \ldots \ldots \ldots \ldots \ldots \ldots \ldots \ldots \ldots \ldots \ldots \ldots \ldots \ldots \ldots \ldots$

List of Contributors $\ldots \ldots \ldots \ldots \ldots \ldots \ldots \ldots \ldots \ldots \ldots \ldots \ldots \ldots \ldots \ldots \ldots$

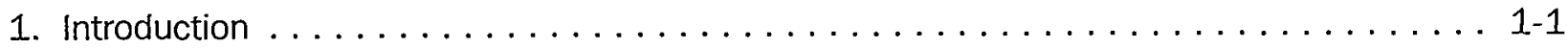

1.1 Location and Description of the Idaho National Engineering and

Environmental Laboratory $\ldots \ldots \ldots \ldots \ldots \ldots \ldots \ldots \ldots \ldots \ldots$

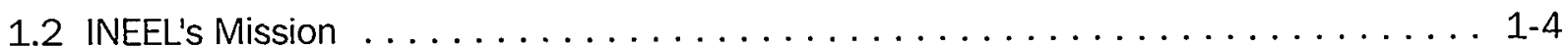

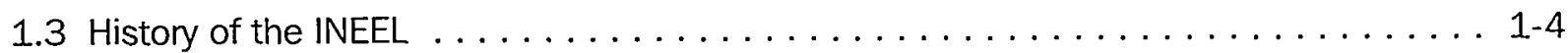

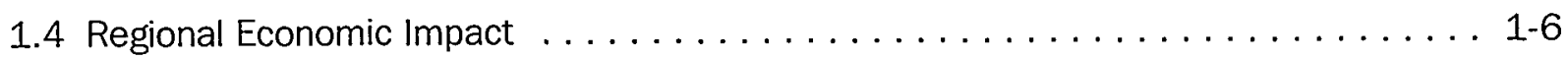

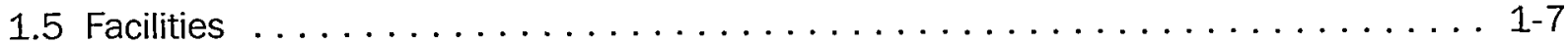

Argonne National Laboratory-West (ANL-W) $\ldots \ldots \ldots \ldots \ldots \ldots \ldots \ldots \ldots \ldots \ldots$

Idaho Nuclear Technology and Engineering Center (INTEC) . . . . . . . . . . . 1-7

Test Area North (TAN) . . . . . . . . . . . . . . . . . . . . . . . . . 1-7

Test Reactor Area (TRA) $\ldots \ldots \ldots \ldots \ldots \ldots \ldots \ldots \ldots \ldots \ldots \ldots \ldots$. . . . . . . . . . . . . .

Waste Reduction Operations Complex/Power Burst Facility (PBF) $\ldots \ldots \ldots \ldots \ldots$ 1-7

Naval Reactors Facility (NRF) . . . . . . . . . . . . . . . . . . . . 1-8

Radioactive Waste Management Complex $(\mathrm{RWMC}) \ldots \ldots \ldots \ldots \ldots \ldots \ldots \ldots \ldots$

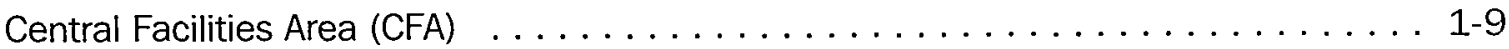

Idaho Falls . . . . . . . . . . . . . . . . . . . . . . .

2. Environmental Compliance Summary . . . . . . . . . . . . . . . 2-1

2.1 Compliance Status . . . . . . . . . . . . . . . . . . . . . . 2-3

Comprehensive Environmental Response, Compensation and Liability Act (CERCLA) . . 2-3

Emergency Planning and Community Right-to-Know Act (EPCRA) . . . . . . . . . 2-3

Natural Resource Trusteeship \& Natural Resources Damage Assessment . . . . . . . . 2-4

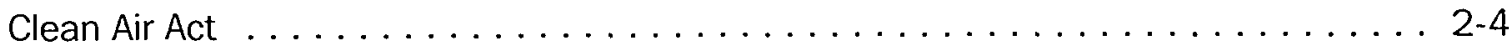

National Emission Standards for Hazardous Air Pollutants $\ldots \ldots \ldots \ldots \ldots \ldots$ 


\section{Contents (Cont.)}

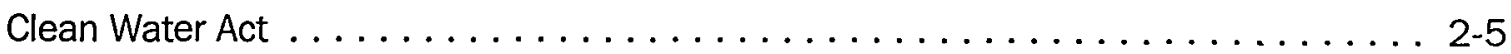

National Pollutant Discharge Elimination System Point Source Discharge Permits . . . 2-6

Executive Order 11990-Protection of Wetlands . . . . . . . . . . . . . . 2-6

Executive Order 11988-Floodplain Management . . . . . . . . . . . . . . . . . 2-7

State of Idaho Wastewater Land Application Permits . . . . . . . . . . . . . . 2-7

Resource Conservation and Recovery Act (RCRA) . . . . . . . . . . . . . . . 2-7

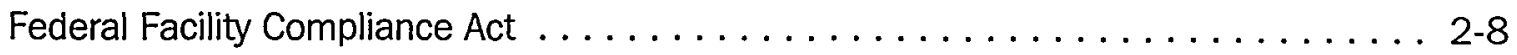

National Environmental Policy Act (NEPA) . . . . . . . . . . . . . . . 2-8

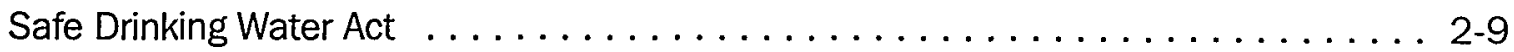

Toxic Substances Control Act . . . . . . . . . . . . . . . . . . . . . . 2-9

Federal Insecticide, Fungicide, and Rodenticide Act (FIFRA) . . . . . . . . . 2-9

National Historic Preservation Act $\ldots \ldots \ldots \ldots \ldots \ldots \ldots \ldots \ldots \ldots . \ldots \ldots$. . . . . . . . . . . . . . . . . . . . .

Native American Grave Protection and Repatriation Act . . . . . . . . . . . 2-10

Endangered Species Act . . . . . . . . . . . . . . . . . .

2.2 Other Major Environmental Issues and Activities $\ldots \ldots \ldots \ldots \ldots \ldots \ldots \ldots$ 2-11

Litigation Issues . . . . . . . . . . . . . . . . . . . . . . . .

Ground Water Monitoring Program Activities . . . . . . . . . . . . . . 2-12

Health Studies . . . . . . . . . . . . . . . . . . . . . . . . 2-13

Environmental Occurrences . . . . . . . . . . . . . . . . . . . 2-14

Environmental Oversight and Monitoring Agreement $\ldots \ldots \ldots \ldots \ldots \ldots \ldots$ 2-14

Citizens Advisory Board . . . . . . . . . . . . . . . . . . . 2-15

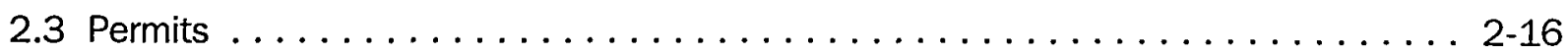

3. Environmental Program Information $\ldots \ldots \ldots \ldots \ldots \ldots \ldots \ldots \ldots \ldots \ldots \ldots$

3.1 Environmental Management System $\ldots \ldots \ldots \ldots \ldots \ldots \ldots \ldots \ldots \ldots \ldots$

3.2 Environmental Restoration Program $\ldots \ldots \ldots \ldots \ldots \ldots \ldots \ldots \ldots \ldots \ldots \ldots$

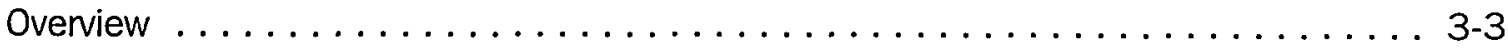

Waste Area Group $1-$ Test Area North (TAN) . . . . . . . . . . . . . . . 3-4

Waste Area Group 2-Test Reactor Area (TRA) . . . . . . . . . . . . . . 3-5

Waste Area Group 3-Idaho Nuclear Technology and Engineering Center (INTEC) . . 3-6

Waste Area Group $4-$ Central Facilities Area (CFA) . . . . . . . . . . . . . . 3-6

Waste Area Group 5-Power Burst Facility(PBF)/Auxiliary Reactor Area (ARA) . . . . . . 3-7

Waste Area Group 6-Boiling Water Reactor Experiment . . . . . . . . . . . . 3-7

Waste Area Group 7-Radioactive Waste Management Complex (RWMC) . . . . . . . 3-8

Waste Area Group 8 -Naval Reactors Facility (NRF) . . . . . . . . . . . . . 3-9

Waste Area Group 9-Argonne National Laboratory-West (ANL-W) . . . . . . . . . . 3-9

Waste Area Group 10-Miscellaneous Sites/Snake River Plain Aquifer . . . . . . . . . 3-9

3.3 Waste Management Program $\ldots \ldots \ldots \ldots \ldots \ldots \ldots \ldots \ldots \ldots \ldots$ 3-10 


\section{Contents (Cont.)}

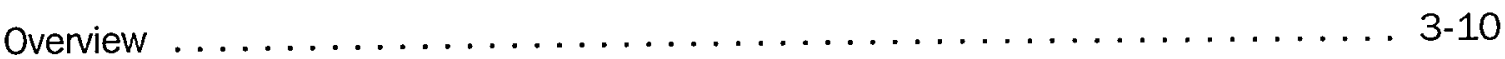

Idaho Settlement Agreement . . . . . . . . . . . . . . . . . . . . . 3-15

Waste-related Research and Development . . . . . . . . . . . . .

3.4 Environmental Risk Reduction . . . . . . . . . . . . . . . . . . . 3-19

Decontamination \& Dismantlement (D\&D)/Demolition Activities . . . . . . . . . 3-19

3.5 National Programs Managed at DOE-ID $\ldots \ldots \ldots \ldots \ldots \ldots \ldots \ldots \ldots \ldots \ldots$

3.6 Additional Environmental Programs $\ldots \ldots \ldots \ldots \ldots \ldots \ldots \ldots \ldots \ldots \ldots$ 3-22

3.7 Environmental Monitoring . . . . . . . . . . . . . . . . . . 3-25

Purpose and Organization of Monitoring Programs . . . . . . . . . . . . $3-25$

Effluent Monitoring Programs . . . . . . . . . . . . . . . . . . . . 3-25

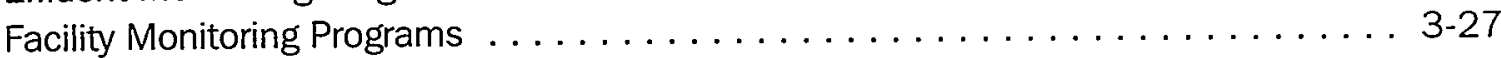

Drinking Water Programs . . . . . . . . . . . . . . . . . . . . . 3-27

Storm Water Monitoring Program . . . . . . . . . . . . . . . . . . . 3-28

Site Environmental Surveillance Program . . . . . . . . . . . . . . . . 3-28

Offsite Environmental Surveillance Program . . . . . . . . . . . . . . . . 3-30

USGS Ground-water Monitoring Program $\ldots \ldots \ldots \ldots \ldots \ldots \ldots \ldots . \ldots \ldots$ 3-34

Meteorological Monitoring Program .................... 3-35

INEEL Oversight Program . . . . . . . . . . . . . . . . . . . .

4. Environmental Radiological Program Results $\ldots \ldots \ldots \ldots \ldots \ldots \ldots \ldots \ldots \ldots \ldots$. . . .

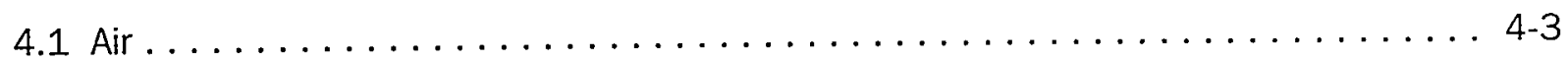

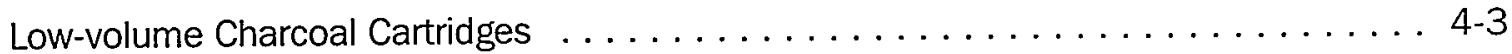

Low-volume Gross Alpha . . . . . . . . . . . . . . . . . . . . . 4-3

Low-volume Gross Beta $\ldots \ldots \ldots \ldots \ldots \ldots \ldots \ldots \ldots \ldots \ldots \ldots \ldots \ldots \ldots$

Statistical Comparisons . . . . . . . . . . . . . . . . . . . . . 4-3

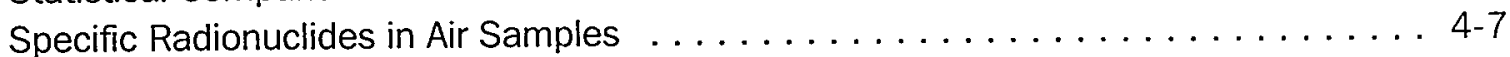

Atmospheric Moisture . . . . . . . . . . . . . . . . . . . . 4-7

Precipitation . . . . . . . . . . . . . . . . . .

4.2 Water $\ldots \ldots \ldots \ldots \ldots \ldots \ldots \ldots \ldots \ldots \ldots \ldots \ldots \ldots \ldots \ldots \ldots \ldots \ldots \ldots$

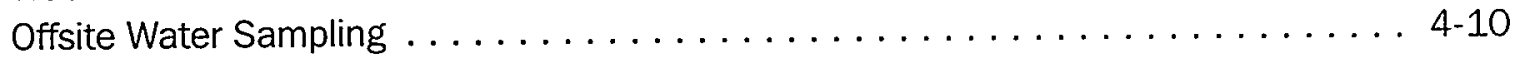

Storm Water Sampling . . . . . . . . . . . . . . . . . . . 4-10

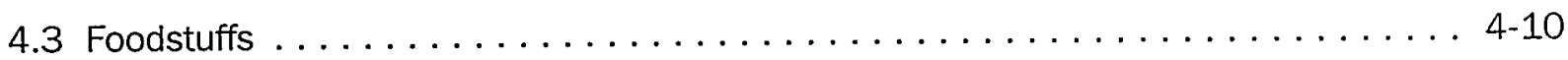

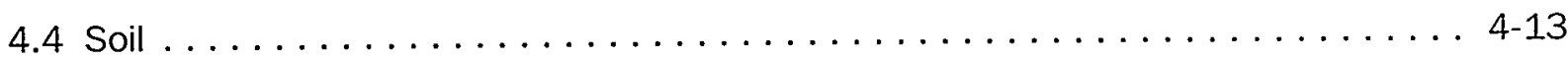

4.5 Environmental Dosimeters $\ldots \ldots \ldots \ldots \ldots \ldots \ldots \ldots \ldots \ldots \ldots \ldots \ldots$. $\ldots \ldots$ 


\section{Contents (Cont.)}

5. Nonradiological Environmental Monitoring Results . . . . . . . . . . . . . . 5-1

5.1 Total Suspended Particulates $\ldots \ldots \ldots \ldots \ldots \ldots \ldots \ldots \ldots \ldots \ldots \ldots$

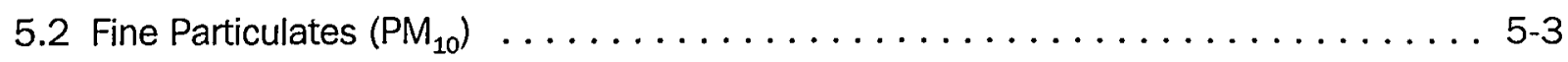

5.3 Nitrogen Dioxide $\ldots \ldots \ldots \ldots \ldots \ldots \ldots \ldots \ldots \ldots \ldots \ldots \ldots \ldots \ldots \ldots \ldots \ldots$

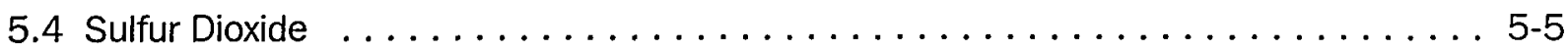

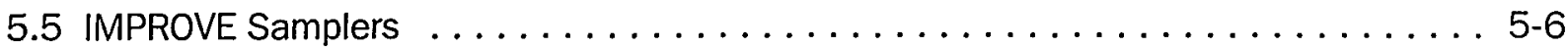

5.6 Storm Water Monitoring $\ldots \ldots \ldots \ldots \ldots \ldots \ldots \ldots \ldots \ldots \ldots \ldots \ldots$

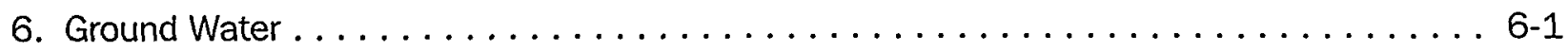

6.1 Aquifer Studies . . . . . . . . . . . . . . . . . . . . . .

Program Information . . . . . . . . . . . . . . . . . . . . .

Summary of USGS Special Studies $\ldots \ldots \ldots \ldots \ldots \ldots \ldots \ldots \ldots \ldots \ldots \ldots$

6.2 Non-Radiological Monitoring . . . . . . . . . . . . . . . . . 6-8

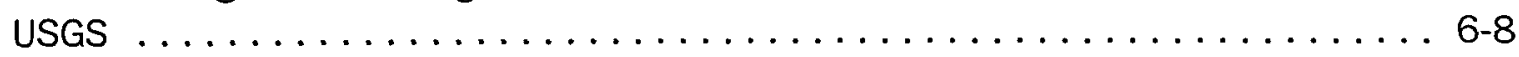

M\&O Contractor . . . . . . . . . . . . . . . . . . . . . . 6-9

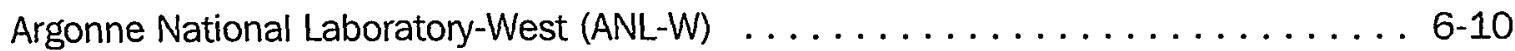

Naval Reactors Facility (NRF) . . . . . . . . . . . . . . . . . 6-10

6.3 Radiochemical Monitoring . . . . . . . . . . . . . . . . . . . . . 6-10

USGS: Contaminant Plumes . . . . . . . . . . . . . . . . . . . . .

M\&O Contractor . . . . . . . . . . . .

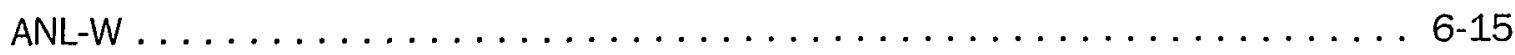

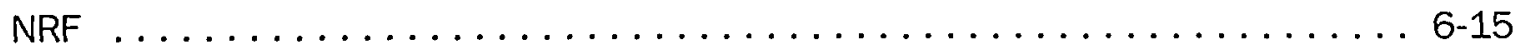

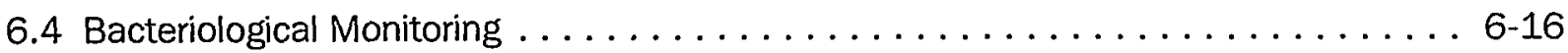

M\&O Contractor .......................... 6.16

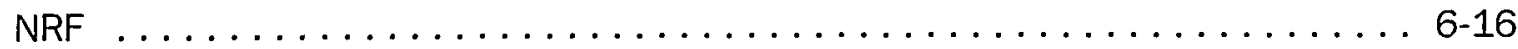

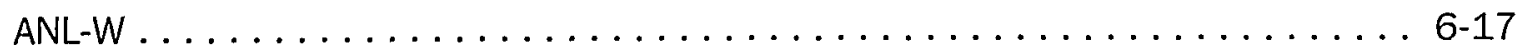

7. Effluent Monitoring $\ldots \ldots \ldots \ldots \ldots \ldots \ldots \ldots \ldots \ldots \ldots \ldots \ldots \ldots \ldots \ldots \ldots$

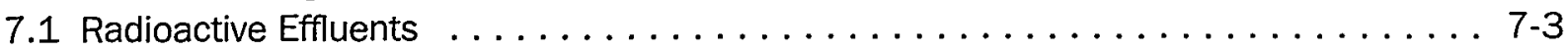

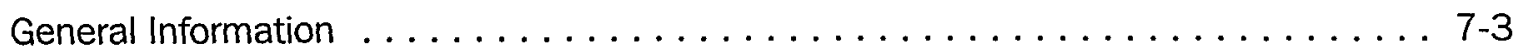

Airborne Effluents . . . . . . . . . . . . . . . . .

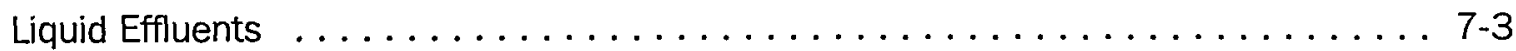




\section{Contents (Cont.)}

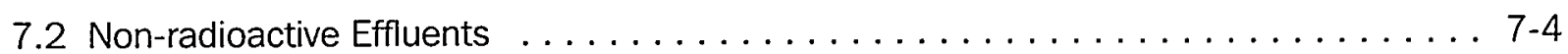

Airborne Effluents . . . . . . . . . . . . . . . . . . . . . . . $7-4$

Liquid Effluents $\ldots \ldots \ldots \ldots \ldots \ldots \ldots \ldots \ldots \ldots \ldots \ldots \ldots \ldots \ldots \ldots$

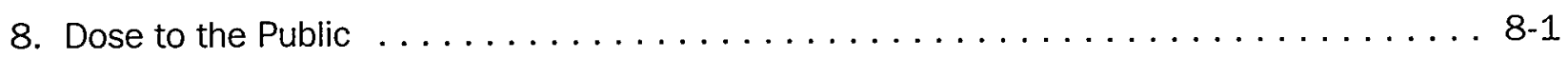

8.1 General Information $\ldots \ldots \ldots \ldots \ldots \ldots \ldots \ldots \ldots \ldots \ldots$

8.2 Maximum Individual Dose - Airborne Emissions Pathway . . . . . . . . . . . 8-3

Summary of Models . . . . . . . . . . . . . . . . . . . . . .

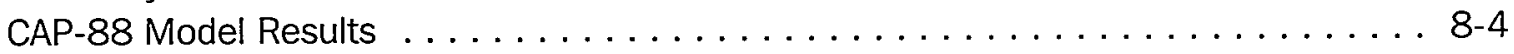

MDIFF Model Results $\ldots \ldots \ldots \ldots \ldots \ldots \ldots \ldots \ldots \ldots \ldots \ldots \ldots$

8.3 Maximum Individual Dose - Game Ingestion Pathway $\ldots \ldots \ldots \ldots \ldots$

8.480 -Kilometer Population Dose $\ldots \ldots \ldots \ldots \ldots \ldots \ldots \ldots \ldots$

8.5 Summary $\ldots \ldots \ldots \ldots \ldots \ldots \ldots \ldots \ldots \ldots \ldots \ldots \ldots \ldots \ldots$

9. Quality Assurance . . . . . . . . . . . . . . . . . . . . 9 -1

9.1 Quality Assurance Programs $\ldots \ldots \ldots \ldots \ldots \ldots \ldots \ldots \ldots \ldots$

9.2 Laboratory Intercomparison Programs $\ldots \ldots \ldots \ldots \ldots \ldots \ldots \ldots \ldots \ldots \ldots$

General Information . . . . . . . . . . . . . . . . . . . . $9-3$

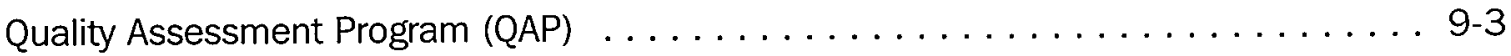

National Institute of Standards and Technology (NIST) . . . . . . . . . . . . 9-4

EPA Intercomparison Studies Program . . . . . . . . . . . . . . . . 9-4

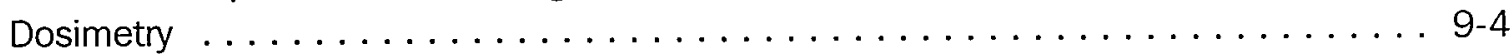

Blind Spikes . . . . . . . . . . . . . . . . . . . . . . 94

Other Programs $\ldots \ldots \ldots \ldots \ldots \ldots \ldots \ldots \ldots \ldots \ldots \ldots \ldots \ldots \ldots$

9.3 Data Precision and Verification $\ldots \ldots \ldots \ldots \ldots \ldots \ldots \ldots \ldots \ldots \ldots$

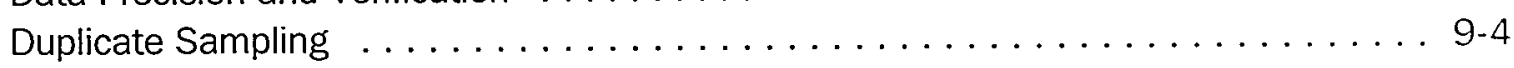

Appendix $A$ - Environmental Standards and Regulations $\ldots \ldots \ldots \ldots \ldots \ldots \ldots$

Appendix B — Statistical Methods Used for the Environmental Surveillance Program . . . . . . B-1

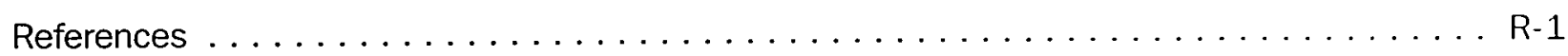




\section{Figures}

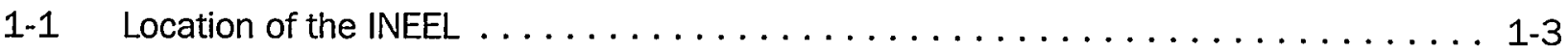

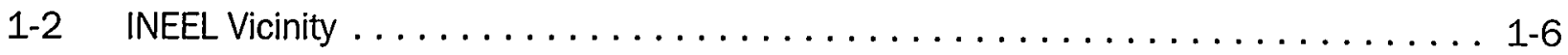

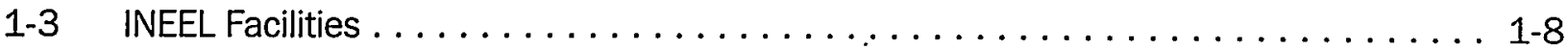

3-1 Potential Pathways from the INEEL to Humans $\ldots \ldots \ldots \ldots \ldots \ldots \ldots \ldots \ldots . \ldots \ldots$

3-2 Low-volume Air Sampler Locations . . . . . . . . . . . . . . . . . 3-32

3-3 Offsite Foodstuff Sampling and Environmental Dosimeter Locations . . . . . . . . . . 3-34

4-1 Weekly Gross Beta Concentrations in Air (1998) . . . . . . . . . . . . . . . . 4-6

4-2 Radionuclides in Offsite Surface Soils $(1975-1998) \ldots \ldots \ldots \ldots \ldots \ldots$. . . . . . . . .

4-3 Environmental Dosimeter Measurements at ANL-W (1998) . . . . . . . . . . . . 4-19

4-4 Environmental Dosimeter Measurements at ARA (1998) ... . . . . . . . . . . . 4-19

4-5 Environmental Dosimeter Measurements at CFA (1998) . . . . . . . . . . . 4-20

4-6 Environmental Dosimeter Measurements at INTEC (1998) . . . . . . . . . . . . . . . 4-20

4-7 Environmental Dosimeter Measurements at NRF (1998) . . . . . . . . . . . 4-21

4-8 Environmental Dosimeter Measurements at PBF (1998) . . . . . . . . . . . . 4-21

4-9 Environmental Dosimeter Measurements at RWMC (1998) . . . . . . . . . . . 4-22

4-10 Environmental Dosimeter Measurements at TAN (1998) . . . . . . . . . . . . . 4-22

4-11 Environmental Dosimeter Measurements at TRA (1998) . . . . . . . . . . . . . . 4-23

4-12 Environmental Dosimeter Measurements along Lincoln Blvd. and US Highway $20(1998) \ldots \ldots \ldots \ldots \ldots \ldots \ldots \ldots \ldots \ldots . \ldots . . .23$

5-1 Nitrogen Oxides and Sulfur Dioxide Monitoring Locations $\ldots \ldots \ldots \ldots \ldots \ldots \ldots$. $\ldots \ldots$

5-2 Nitrogen Dioxide and Sulfur Dioxide Concentrations at the INEEL (1990-1998) . . . . 5 5-5

5-3 Very Fine Mass $\left(\mathrm{PM}_{2.5}\right)$ Concentrations at Craters of the Moon and CFA (1992-1998) . 5-7 


\section{Figures (Cont.)}

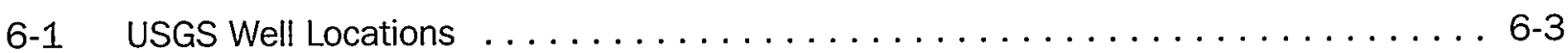

$6-2$ USGS Well Locations at INTEC, TRA and RWMC $\ldots \ldots \ldots \ldots \ldots \ldots$

6-3 Monitoring Wells around $\mathrm{NRF} \ldots \ldots \ldots \ldots \ldots \ldots \ldots \ldots \ldots \ldots$

6-4 Distribution of Tritium in the Snake River Plain Aquifer on the INEEL (1995) $\ldots . \ldots 6-14$

6-5 Distribution of ${ }^{90} \mathrm{Sr}$ in the Snake River Plain Aquifer on the INEEL (1995) $\ldots \ldots$. . 6-16

6-6 Tritium Concentrations in INEEL Production Wells and Distribution Systems $(1987-1998) \ldots \ldots \ldots \ldots \ldots \ldots$. . . . . . . . . .

7-1 INEEL Airborne Radioactive Effluent $\ldots \ldots \ldots \ldots \ldots \ldots \ldots \ldots \ldots \ldots \ldots \ldots$

8-1 Average Mesoscale Dispersion Isopleths of Air Concentrations at Ground Level, Normalized to Unit Release Rate for TRAIINTEC . . . . . . . . . . . . . . . 8-5

8-2 Radionuclides Contributing to Maximum Individual Dose $(1998) \ldots \ldots \ldots$. . . . . 8-6 


\section{Tables}

2-1 INEEL 1998 Emergency Planning and Community Right-to-Know Act (EPCRA) Update . 2-4

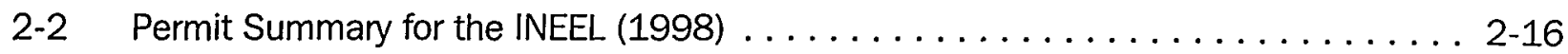

3-1 LMITCO Environmental Surveillance Radiological Program Summary (1998) . . . . . 3-29

3-2 Environmental Science and Research Foundation Environmental Surveillance

Radiological Monitoring Program Summary (1998) . . . . . . . . . . . . 3-31

3-3 USGS Ground-water Monitoring Program Summary $\ldots \ldots \ldots \ldots \ldots \ldots$

4-1 Gross Alpha Activity in Air (1998) . . . . . . . . . . . . . . . . 4-4

4-2 Gross Beta Activity in Air (1998) $\ldots \ldots \ldots \ldots \ldots \ldots \ldots \ldots \ldots \ldots$

4-3 Statistical Comparison of Gross Beta Concentrations in Air at Distant, Boundary and INEEL Locations $(1998) \ldots \ldots \ldots \ldots \ldots \ldots \ldots$. . . . . . . .

4-4 Human-made Radionuclides in Foundation and LMITCO Air Samples (1998) . . . . . 4-9

4-5 Strontium-90 Concentrations in Garden Lettuce (1994-1998) . . . . . . . . . . . . 4-11

4-6 Strontium-90 Concentrations in Wheat $(1994-1998) \ldots \ldots \ldots \ldots$. . . . . . 4-12

4-7 Human-made Radionuclides in Breast Meat of Mourning Doves Collected on the INEEL (1998) . . . . . . . . . . . . . . 4-13

4-8 Human-made Radionuclides Detected in Edible Portions of Waterfowl (1998) . . . . 4-14

4-9 Human-made Radionuclides Detected in Edible Portions of Yellow-Bellied Marmots (1998) . . . . . . . . . . . . . . 4-15

4-10 Environmental Exposures $(1995-1998) \ldots \ldots \ldots \ldots \ldots \ldots \ldots$. . . . . . . . . . . . .

4-11 Estimated Natural Background Effective Dose Equivalent (1998) . . . . . . . . 4 4-18

5-1 Particulate Concentrations in Air (1998) $\ldots \ldots \ldots \ldots \ldots \ldots \ldots \ldots \ldots \ldots$

5-2 Ten-Year Summary of Particulate Matter Concentrations $(1989-1998) \ldots \ldots \ldots$. . . 5 5

5-3 Data for IMPROVE Samplers at CFA and Craters of the Moon (May 1992-November 1998) . . . . . . . . . . . . . . . . . . . 5-6 


\section{Tables (Cont.)}

5-4 Non-radiological Storm Water Monitoring Data (1998) . . . . . . . . . . . . 5-9

6-1 Purgeable Organic Compounds in USGS Well Samples (1998) . . . . . . . . . . . . 6-9

6-2 Purgeable Organic Compounds in INEEL Drinking Water (1998) . . . . . . . . 6-11

6-3 Inorganic Chemicals in INEEL Potable Production Wells (1998) . . . . . . . . 6-12

6-4 Tritium Concentrations in INEEL Production Wells and Distribution Systems (1998 . . 6-15

7-1 Radionuclide Composition of INEEL Airborne Effluents (1998) $\ldots \ldots \ldots \ldots \ldots$. . . 7-4

7-2 Radionuclide Composition of Liquid Effluent Released Onsite (1998) . . . . . . . . 7-5

7-3 INTEC Service Waste Inorganic Monitoring Data (1998) . . . . . . . . . . . 7-6

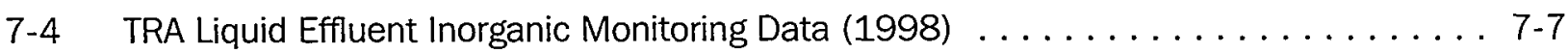

8-1 Maximum Individual Effective Dose Equivalent (1998) . . . . . . . . . . . 8-6

8-2 Maximum Potential Committed (50 yr) Effective Dose Equivalents from Ingestion of Muscle Tissue of Waterfowl Using INEEL Waste Disposal Ponds in 1998 (mrem) . . . . 8-7

8-3 Maximum Potential Committed (50 yr) Effective Dose Equivalents from Ingestion of Muscle Tissue of Mourning Doves Using INEEL Waste Ponds in 1998 (mrem) . . . . . 8-8

8-4 Dose to Population within 80 kilometers (50 miles) of INEEL Center (1998) . . . . . 8-9

8-5 Summary of Annual Effective Dose Equivalents Due to INEEL Operations (1998) . . . 8-10

9-1 Environmental Measurements Laboratory (EML) Quality Assessment Program Results for the Environmental Assessment Laboratory (EAL) (1998) . . . . . . . . 9 9-5

9-2 Environmental Measurements Laboratory (EML) Quality Assessment Program Results for General Engineering Labs (GEL) (1998) . . . . . . . . . . . . . . 9-6

9-3 Environmental Measurements Laboratory (EML) Quality Assessment Program Results for LMITCO (1998) . . . . . . . . . . . . . . . . . . . . . . . . . . 9 9-7

9-4 Environmental Measurements Laboratory (EML) Quality Assessment Program Results for Paragon Analytics, Inc. (1998) . . . . . . . . . . . . . . . . . . . . 9-9

9-5 Environmental Measurements Laboratory (EML) Quality Assessment Program Results 


\section{Tables (Cont.)}

for Quanterra, Inc. (1998). . . . . . . . . . . . . . . . . . . . . 9-11

9-6 Comparison of Duplicate Air Monitoring Results (1998) . . . . . . . . . . . 9-13

9-7 Comparison of Foundation, LMITCO and State of Idaho Air Monitoring Results (1998)-Gross Alpha . . . . . . . . . . . . . . . . . . . . . . . 9 9-14

9-8 Comparison of Foundation, LMITCO and State of Idaho Air Monitoring Results (1998)-Gross Beta . . . . . . . . . . . . . . . . . . . . . . . 9-15

9-9 Comparison of Foundation and State of Idaho Water Monitoring Results (1998) . . . 9-14

A-1 Derived Concentration Guides for Radiation Protection $\ldots \ldots \ldots \ldots \ldots \ldots \ldots$

A-2 Radiation Standards for Protection of the Public in the Vicinity of DOE Facilities . . . . A-3

A-3 EPA Ambient Air Quality Standards $\ldots \ldots \ldots \ldots \ldots \ldots \ldots \ldots \ldots \ldots \ldots$

A-4 EPA Maximum Contaminant Levels for Nontransient Noncommunity Drinking Water Systems . . . . . . . . . . . . . . . . . A 4 


\section{List Of Contributors}

Brad Andersen

W.G. Bass

Roy Bartholomay

Bob Bates

Mike Bennett

Bryan Borsella

Teresa Brock

Lori Fritz

John Gill

Katie Hain

Rosemary Haines

Carol Hathaway

Neil Hukari

Talley Jenkins

Nolan Jensen

Alan Jines

Patti Kroupa

Chuck Ljungberg

Amy Luft

Stacey Madsen

Christopher Martin

Teresa Meachum

John Medema

Maria Miles
Patty Natoni

Joan Neff

R.D.E. Newbry

Kevin O'Neill

Brennon Orr

Don Rasch

Tim Reynolds

Paul Ritter

Woody Russell

Jerry Sagendorf

Mark Shaw

Chris Staley

Leah Street

Karen Taylor

Jim Thompson

Jim Tkachyk

Betty Tucker

Roger Twitchell

Dennis Walker

Ron Warren

Dave Wessman

Roger Wilhelmsen

Mary Willcox 


\section{Chapter 1 \\ Introduction}

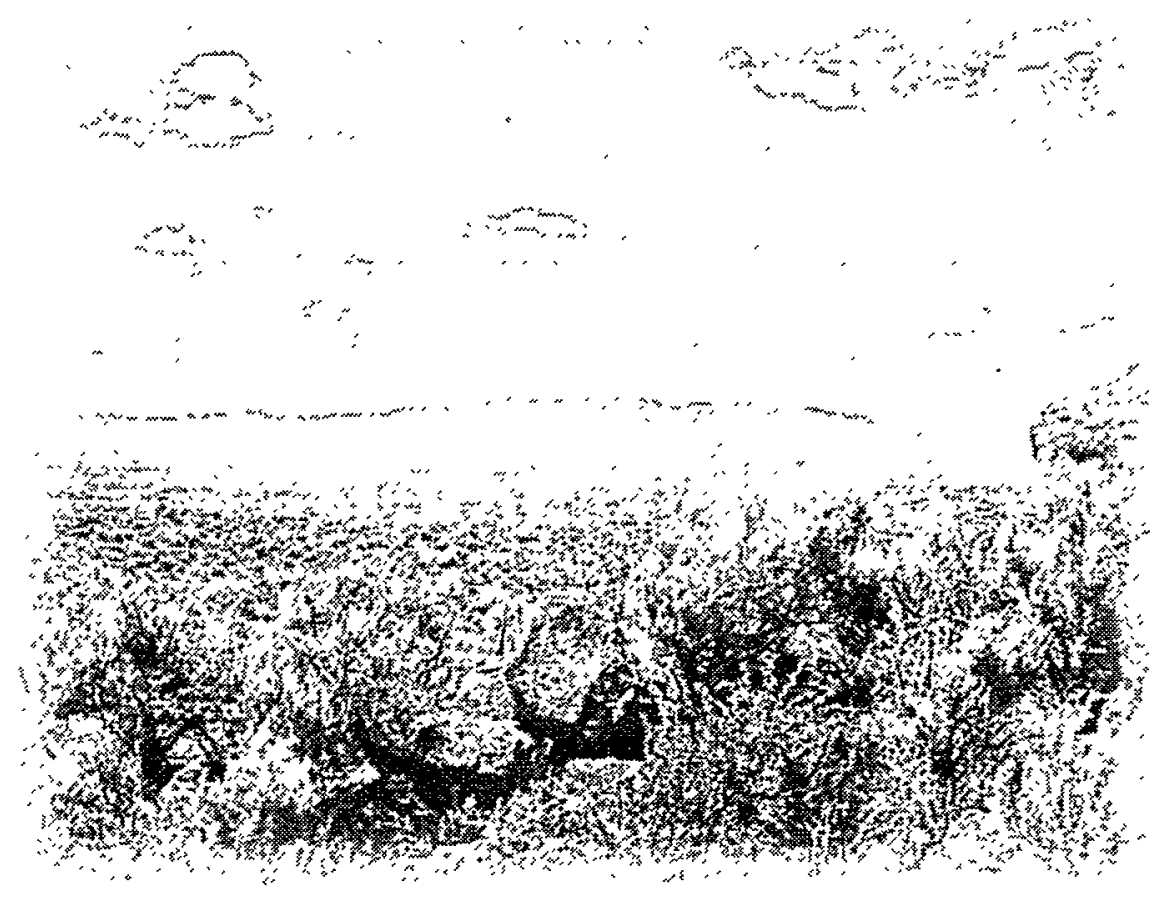




\section{INTRODUCTION}

\subsection{LOCATION AND DESCRIPTION OF THE IDAHO NATIONAL ENGINEERING AND ENVIRONMENTAL LABORATORY}

The U.S. Department of Energy (DOE) owns and administers the Idaho National Engineering and Environmental Laboratory (INEEL). Located in the southeastern portion of the state of Idaho, the INEEL occupies approximately 2,300 $\mathrm{km}^{2}$ (890 square miles) of the upper Snake River Plain and covers an important and relatively undisturbed expanse of the sagebrushsteppe ecosystem [Reference 1-1]. The INEEL extends $63 \mathrm{~km}$ (39 miles) from north to south and is about $58 \mathrm{~km}$ (36 miles) wide at its broadest east-west portion (Figure 1-1). The average elevation on the INEEL is approximately $1,500 \mathrm{~m}(4,900$ feet $)$ above sea level. The Site is bordered on the north and west by mountain ranges and on the south by three volcanic buttes. Lands immediately beyond the boundaries of the INEEL are desert, foothills, and agricultural fields. Most of the nearby farming is concentrated northeast of the INEEL. Large areas of agricultural land are farmed adjacent to the Snake River, but these regions are more distant from the INEEL.

The altitude, intermountain setting, and latitude of the INEEL combine to produce a semiarid climate [Reference 1-2]. Prevailing weather patterns are from the southwest, moving up the Snake River Plain. Air masses, which gather moisture over the Pacific Ocean, traverse several hundred miles of mountainous land prior to reaching southeastern Idaho. The result is frequently dry air and little cloud cover. Solar heating can be intense with extreme dayto-night temperature fluctuations.

The climate of the cold desert environment of the INEEL is characterized by sparse precipitation, hot summers, and cold winters. The climate and mostly alkaline soils support plant communities and animal populations able to cope with both dryness and temperature

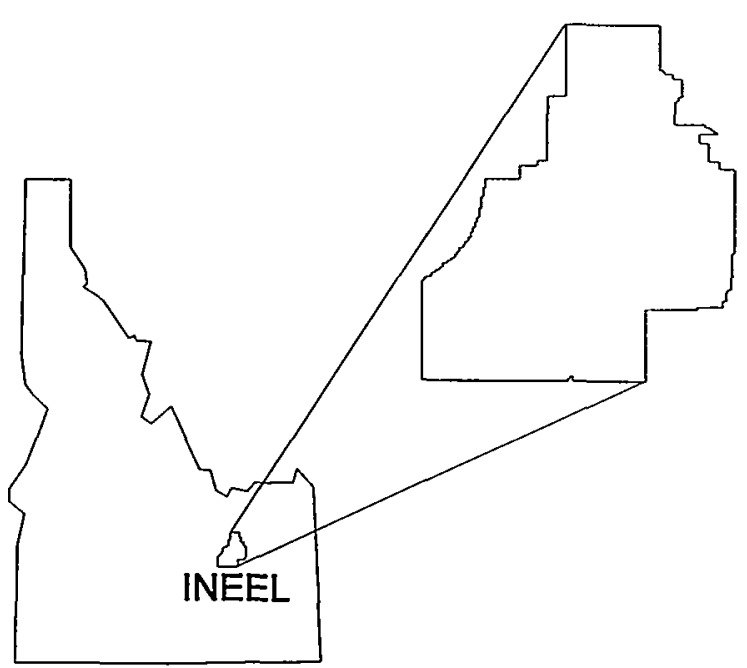

Figure 1-1. Location of the INEEL

extremes. Most of the plain is covered by basalt flows, which produce a rolling topography. Vegetation is visually dominated by big sagebrush. Beneath these shrubs are grasses and flowering plants, most adapted to the harsh climate. A recent inventory counted 409 plant species on the INEEL [Reference 1-3]. Vertebrate animals found on the INEEL include small burrowing mammals, snakes, birds, and several game species. Published species counts include six fishes, two amphibians, 11 reptiles, 224 birds and 44 mammals [Reference 1-4]. Sixty percent of the INEEL is open to livestock grazing.

Within the plain, and its ample basalt flows interspersed with sedimentary deposits, is a productive aquifer. The eastern Snake River Plain Aquifer, which passes under the INEEL and stretches over $270 \mathrm{~km}$ (165 miles) from St. Anthony, ID to Bliss, ID, stores one of the most bountiful supplies of ground water in the nation. An estimated 200 to 300 million acrefeet of water are stored in the aquifer's upper portions. Significant recharge of the aquifer beneath the INEEL comes from waters of the Henry's Fork and the South Fork of the Snake 
River, as well as the Big Lost River, the Little Lost River, and Birch Creek. In this century, irrigation recharge accounted for as much as 60 percent of the water returning to the aquifer. The Big Lost River and Birch Creek flow onto the INEEL during wet periods. There, they sink into porous soils. Beneath the INEEL, the aquifer moves laterally to the southwest at a rate of $1.5 \mathrm{~m}$ to $6 \mathrm{~m}$ per day (5 to 20 feet per day). The eastern Snake River Plain Aquifer emerges in springs along the Snake River between Milner and Bliss, ID. On the Snake River Plain the main use of both surface water and ground water is for crop irrigation.

The INEEL consists of several primary facility areas located on an expanse of otherwise undeveloped terrain. Most buildings and structures on the INEEL are situated within facilities, leaving about 94 percent of the INEEL open, undeveloped land [Reference 1-5].

\subsection{INEEL'S MISSION}

The present mission of the INEEL is "to develop, demonstrate, deploy, and transfer advanced engineering technology and systems to private industry to improve U.S. competitiveness and security, the efficient production and use of energy, and the quality of life and the environment worldwide" [Reference 1-6].

In addition to this stated mission, the Department of Energy - Idaho Operations Office (DOE-ID) is committed to providing a safe and healthy workplace for its employees, protecting public health and safety, and protecting the environment.

The INEEL was designated the second of seven National Environmental Research Parks (NERPs) in 1975. NERPs were established to evaluate the environmental consequences of energy use and development, as well as the strategies to mitigate such effects [Reference 1-7].
About 60 percent of the INEEL's funding is devoted to environmental restoration and waste management activities. The INEEL's environmental program is laid out over the next 40 years through the Idaho Settlement Agreement for spent nuclear fuel and radioactive waste, the Site Treatment Plan for Mixed Wastes, and a cleanup agreement among the DOE, the state of Idaho, and the Environmental Protection Agency. These legally enforceable agreements are geared toward assessing and remediating past contamination of the Site and putting wastes now stored at the INEEL in more stable forms that are ready for disposal when permanent repositories become available.

The other 40 percent of the INEEL budget funds ongoing programs like the Advanced Test Reactor and research into a wide range of fields, including energy efficiency, renewable energy, technology development, systems engineering, and other areas.

\subsection{HISTORY OF THE INEEL}

The geologic events that have shaped the modern Snake River Plain on and near the INEEL took place during the last two million years [References 1-8 and 1-9]. The plain, which arcs across eastern Oregon and southern Idaho, marks the passage of the earth's crust over a dome of mantle material pressing up from the super-heated center of the planet. The resultant lava flows are oldest in the west and youngest at the Yellowstone Plateau, where the thermal upwelling is most evident today. The plain is a $650 \mathrm{~km}$ (400 mile) trail made by the passage of the continent over this "hot spot."

Human use of the upper Snake River Plain, and especially of the lands of the INEEL, has been sporadic since humans appeared in the area 10,000 to 12,000 years ago. The Shoshone and Bannock peoples lived in socially fluid groups that traveled among the mountains, plains, and river bottoms as their 
seasonal needs changed. From the plain, game animals were taken in late summer. Obsidian and other useful stones were quarried at Big Southern Butte. Plants, from camas to dogbane, were gathered. A prime route between the Fort Hall area and the Camas Prairie passed across the plain near the three buttes, and across what became the INEEL.

The earliest exploratory visits by European descendants came in the 1810s, '20s, and '30s. Trappers ranged over the plain seeking new supplies of beavers for pelts. Their impressions discouraged potential settlers, and the pioneers using the Oregon Trail avoided lingering in the high desert. The second half of the 1800 s saw valuable ores mined in the surrounding mountains and the beginning of cattle and sheep grazing in the valleys. More lines of transportation - stock trails and stage routes - pressed across the plain. A railroad opened between Blackfoot and Arco in 1901. There was by then sufficient enticement for homesteaders to attempt to win a section of land on the plain. The Carey Land Act of 1894 and the Desert Reclamation Act of 1902 are credited as setting the stage for Idaho's irrigation-based farming economy. The heart of the plain remained immune to irrigation. The porosity of its soils could not be overcome, and water drained out of the bottom of newly-built canals faster than it could be carried to crops and stock. A broad swath of the eastern plain is still sparsely inhabited.

World War II brought the U.S. Naval Ordnance Station to Pocatello, ID. At this station, one of just two such installations in the U.S., large guns from the U.S. Navy ships were retooled. This facility was located inland for fear of being too enticing of a target for enemy bombs along a coast. The retooled guns needed to be tested, and the nearby, uninhabited plain was put to use as a gunnery range, called the Naval Proving Ground. In the aftermath of the war, as the nation moved to learn how to tame the newly-released powers within atoms, the Naval Proving Ground caught the eye of the Atomic Energy Commission (AEC). On the AEC's drawing boards were plans for an isolated facility with an ample water supply at which to build, test, and perfect nuclear reactors. The plain was chosen as the best location.

The Naval Proving Ground became the National Reactor Testing Station (NRTS) in 1949, under the Atomic Energy Commission, predecessor to the DOE. The NRTS technological mission required both of the defining characteristics of the Snake River Plain: desert land and ample ground water. The station's administrative offices were situated in Idaho Falls, then a city of less than 20,000 . By the end of 1951, a reactor at the NRTS produced useful electricity. The facility evolved into an assembly of 52 reactors, associated research centers, and waste handling areas. Only three reactors are operable today. The NRTS was renamed the Idaho National Engineering Laboratory in 1974 and Idaho National Engineering and Environmental Laboratory in January, 1997 [Reference 1-10].

The human population, based on 1990 census figures, living within $80 \mathrm{~km}$ (50 miles) of the INEEL's operational center is 121,500 [Reference 1-11]. There are no permanent residents within $16 \mathrm{~km}$ (10 miles) of that center (Figure 1-2). Atomic City (population 25 ) is the closest community to the INEEL's center. Other boundary communities include Arco (population 1,106), Howe (population 20), Monteview (population 10), Mud Lake (population 179), and Terreton (population 100). The larger population centers of Idaho Falis (population 49,928), Blackfoot (population 10,769), and Pocatello (population $50,588)$ are at least $35 \mathrm{~km}$ (22 miles) from the nearest INEEL boundary. 


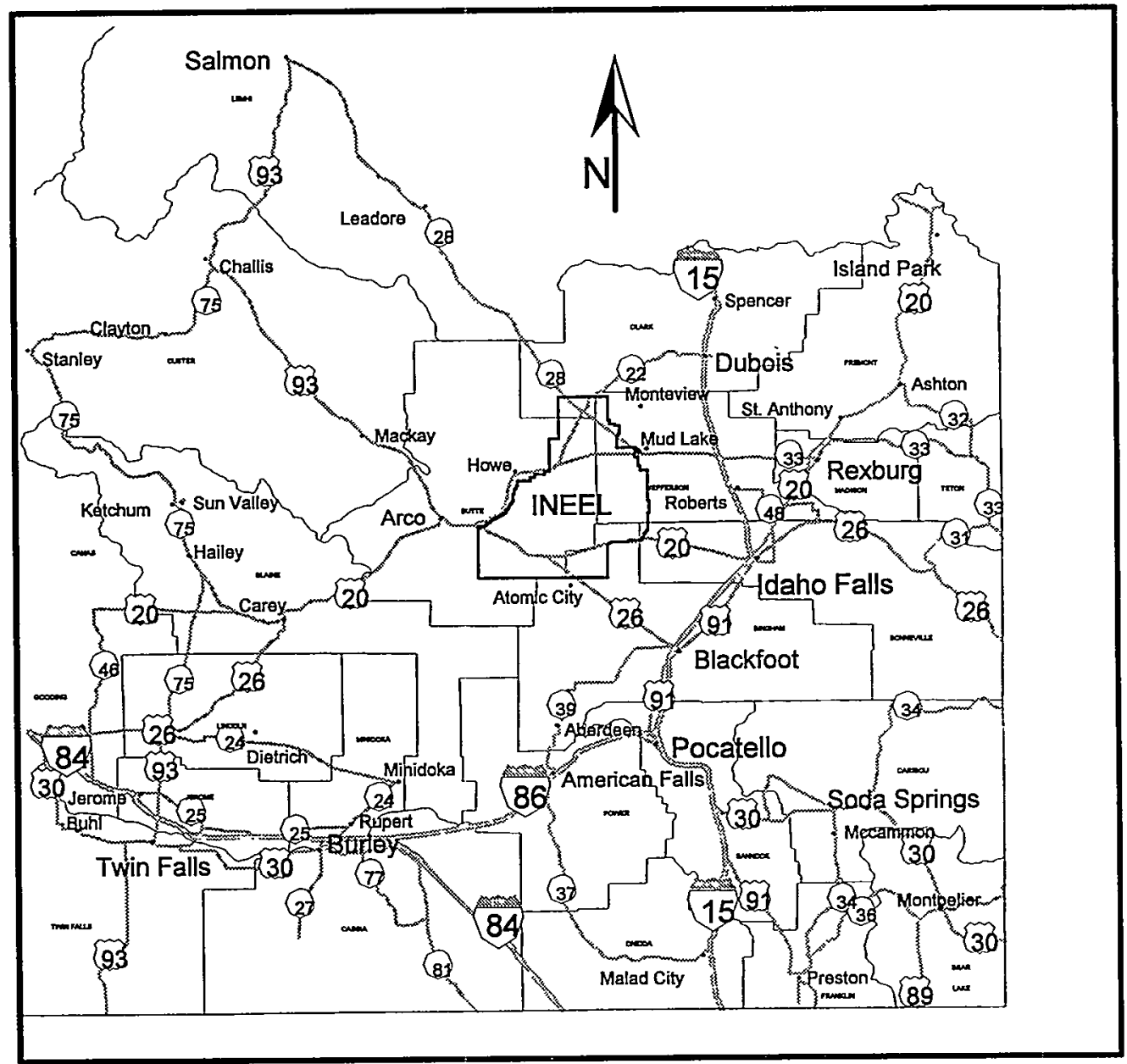

Figure 1-2. INEEL Vicinity

\subsection{REGIONAL ECONOMIC IMPACT}

Approximately 8,100 people work at the INEEL, making it the largest employer in eastern Idaho and the second largest employer in the state. This number includes about 400 federal employees, most of whom work for DOE-ID. In 1998, the majority of the other 7,700 worked for Lockheed Martin Idaho Technologies Company (LMITCO). Others worked for contractors such as Bechtel Bettis, Inc. and the University of Chicago's Argonne National Laboratory.

The INEEL has a tremendous economic impact on eastern Idaho. The following statistics demonstrate why the INEEL is an integral component of Idaho's economy and society [Reference 1-10]. 
- The INEEL generated approximately 16,000 jobs and accounted for almost half a billion dollars in economic activity for Idaho.

- Nearly $\$ 100$ million worth of goods and services were purchased by the INEEL from Idaho businesses. Nearly 81 percent were purchased from businesses in southeastern Idaho.

- Altogether, INEEL families paid $\$ 132.6$ million in taxes.

- DOE and INEEL contractors consistently give their time and income to the community through various civic activities. In 1998, INEEL employees gave over \$1 million back to their communities. Countless hours were contributed to community concerns, church affiliations, educational activities, political and issue-related causes, youth, and other areas of interest.

\subsection{FACILITIES}

In 1998, the Idaho National Engineering and Environmental Laboratory was operated for the U.S. Department of Energy by Lockheed Martin Idaho Technologies Company (LMITCO). Additional facilities were operated by Bechtel Bettis, Inc. and the University of Chicago's Argonne National Laboratory. Facilities are located in the city of Idaho Falls and at eight operating areas on the INEEL (Figure 1-3). Major facilities, and their current missions, are listed in the following sections.

\section{Argonne National Laboratory-West (ANL-W)}

This facility is operated by the University of Chicago's Argonne National Laboratory under contract to the DOE-Chicago Operations Office. The present mission of the laboratory is research into spent nuclear fuel, nuclear proliferation, and waste reduction and cleanup technologies.

\section{Idaho Nuclear Technology and Engineering Center (INTEC)}

The Idaho Nuclear Technology and Engineering Center (INTEC) receives and stores nuclear fuels from the U.S. Navy and other agencies. Technologies for treatment and disposal of high-level waste are being developed at the plant. High-level wastes are being treated and will ultimately be prepared for disposal in a permanent repository.

\section{Test Area North (TAN)}

Located at the north end of the INEEL, TAN was built to house the program to develop a nuclear-powered airplane during the 1950s. Facilities include one of the world's largest "hot shops," which, from 1986 to 1990, also supported research into the Three Mile Island accident. The largest program currently at TAN, the Specific Manufacturing Capability Project, produces armor for the M1A2 Abrams tank for the U.S. Army.

\section{Test Reactor Area (TRA)}

The TRA has studied the effects of radiation on materials, fuels, and equipment for over 40 years. The Advanced Test Reactor at TRA is currently used for the production of important isotopes used in medicine, research, and industry.

\section{Waste Reduction Operations Complex / Power Burst Facility (PBF)}

The PBF area contains the Waste Experimental Reduction Facility, which processes lowlevel waste to reduce waste volume through sizing of metallic waste, compaction, and incineration. 


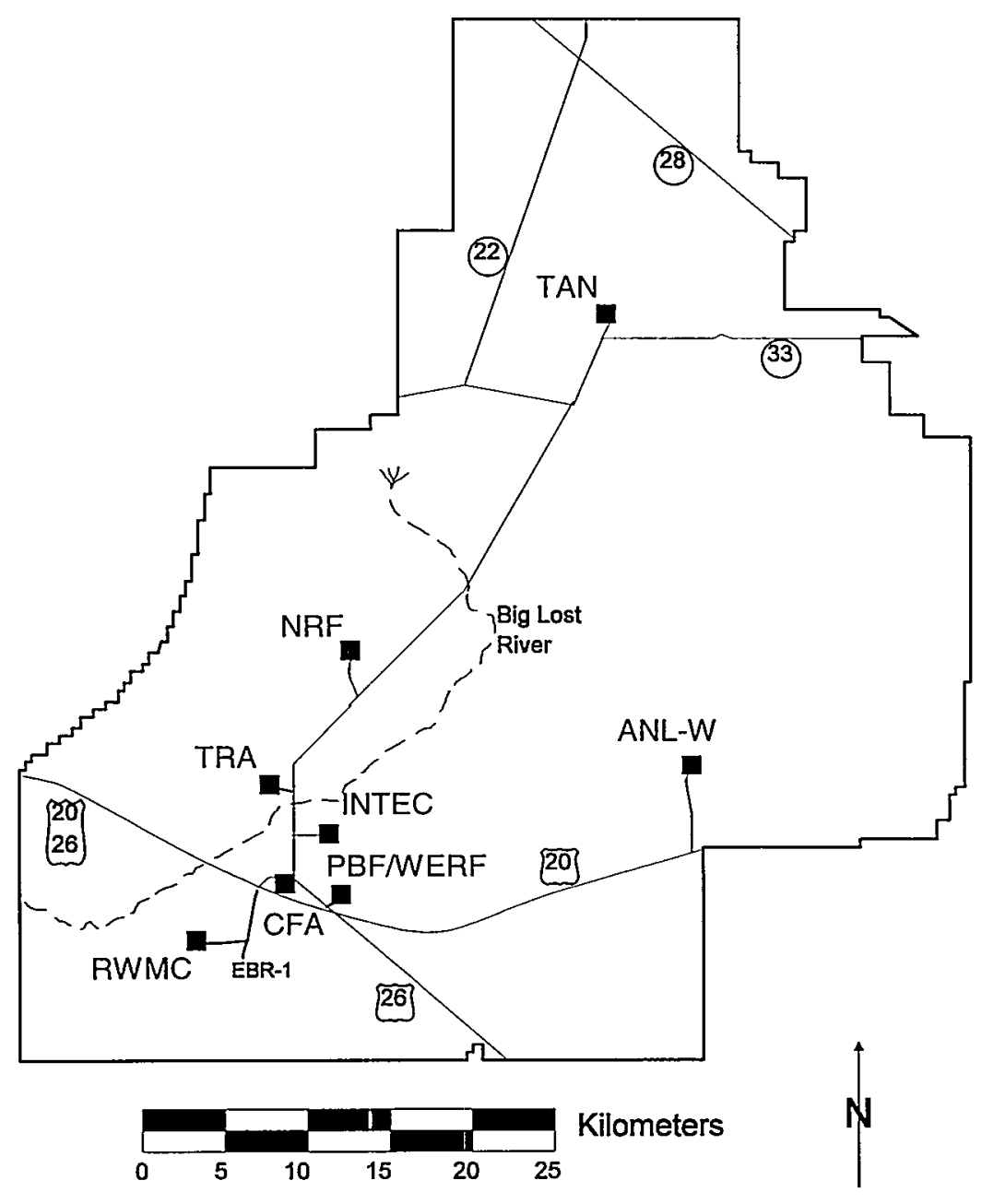

Figure 1-3. INEEL Facilities

\section{Naval Reactors Facility (NRF)}

The NRF is operated by Bechtel Bettis, Inc. for DOE's Pittsburgh Naval Reactors Office. From 1953 through May 1995, NRF prototypeswere used to train Navy personnel who serve aboard nuclear-powered submarines and warships. At the Expended Core Facility, NRF tests and examines naval reactor fuel components to improve current designs and to monitor the performance of existing reactors.

\section{Radioactive Waste Management Complex (RWMC)}

The RWMC's mission is to manage the disposal of low-level radioactive waste and to temporarily store transuranic waste in an environmentally sound manner. The facility studies various strategies for storing, processing, and disposing of radioactive wastes. The Stored Waste Examination Pilot Plant is used to nondestructively examine waste before it can be sent to the Waste Isolation Pilot Plant in New Mexico. 


\section{Central Facilities Area (CFA)}

The CFA is the headquarters for services at the INEEL. The area contains environmental monitoring, radiochemistry, radiation protection, quality assurance, and calibration laboratories; vehicle and equipment pools; a cafeteria; fire and emergency medical facilities; warehouses; various craft shops; and a security facility.

\section{Idaho Falls}

Idaho Falls facilities include the INEEL Research Center, which features programs in materials science, physical science, biotechnology, environmental science, and geotechnology. The Engineering Research Office Building, Willow Creek Building, two DOE buildings, and other buildings house support personnel for the facilities at the INEEL. 


\section{Chapter 2 \\ Environmental Compliance Summary}

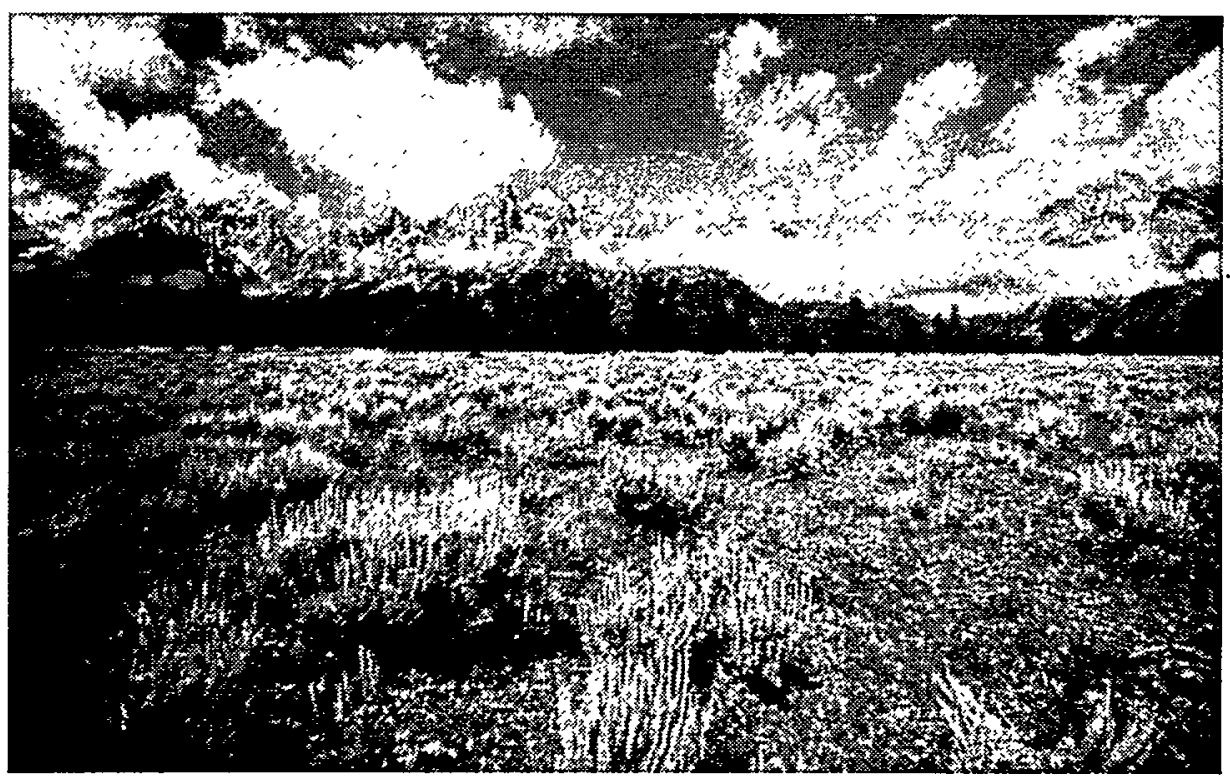


- 


\section{ENVIRONMENTAL COMPLIANCE SUMMARY}

\subsection{COMPLIANCE STATUS}

\section{Comprehensive Environmental Response, Compensation and Liability Act (CERCLA)}

CERCLA provides the specific procedures to assess and remediate inactive waste sites where the release of hazardous substances has occurred. The INEEL was placed on the National Priorities List under CERCLA on November 29, 1989. Environmental restoration activities at the INEEL are being conducted in accordance with the Federal Facility Agreement and Consent Order (Agreement) signed in December 1991 by DOE-ID, the state of Idaho, and EPA Region 10.

During 1998, investigations under the processes outlined in the Agreement continued to be streamlined. Limited field investigations, termed either Track 1 or Track 2, were used to aid in evaluation of many potential release sites. A Track 1 designation is used for potential release sites where existing data are expected to demonstrate that a site needs no further action. Track 2 denotes limited field data collection is necessary. After each limited investigation is completed, a determination is made by the Consent Order Project Managers that no further action is necessary, or that either proceeding with an interim cleanup action or further investigation under a remedial investigation/feasibility study is appropriate. Most currently scheduled Track 1 and Track 2 field investigations have been completed.

Cleanup milestones scheduled in the Agreement were all met during 1998. All Waste Area Groups (WAGs) identified in the Agreement have initiated a Comprehensive Remedial Investigation/Feasibility Study (R//FS) which was intended as the last major investigation at each WAG.

\section{Emergency Planning and Community Right- to-Know Act (EPCRA)}

The purpose of EPCRA is to provide the public with information about hazardous chemicals on the INEEL and to establish emergency planning and notification procedures to protect the public from chemical releases. This act also contains requirements for periodic reporting on hazardous chemicals stored and/or used at the facilities. Executive Order 12856, "Federal Compliance with Right-to-Know Laws and Pollution Prevention Requirements," requires all federal facilities to comply with the provisions of this act. INEEL EPCRA status is summarized in Table 2-1.

311 Report. Quarterly 311 reports were submitted to local emergency planning committees, the State Emergency Response Commission, and to local fire departments by January 1, April 1, July 1, and October 1 in 1998. These quarterly reports satisfy the 90-day notice requirement for new chemicals brought onsite.

312 Report. The Emergency and Hazardous Chemical Inventory (Tier II) Report for 1998 was transmitted to the planning and response agencies before March 1, 1999. This report identified the types, quantities, and locations of hazardous and extremely hazardous chemicals stored at INEEL facilities that exceed CERCLA and Threshold Planning Quantities within EPCRA.

313 Report. The Toxic Chemical Release Inventory Report was transmitted to the EPA and the state of Idaho by July 1,1998 . The report identified quantities of toxic chemicals released to the environment by the INEEL during calendar year 1998. Reports were prepared for three toxic chemicals in 1998: lead, nitric acid, and nitrate compounds. 
Table 2-1. INEEL 1998 EMERGENCY PLANNING AND COMMUNITY RIGHT-TO-KNOW ACT (EPCRA) UPDATE

\begin{tabular}{ll}
\hline EPCRA 302-303: Planning Notification & Yes [ ] No [ ] Not Required $[X]$ \\
EPCRA 304: EHS Release Notification & Yes [ ] No [ ] Not Required $[X]$ \\
EPCRA 311-312: MSDS $/$ Chemical Inventory & Yes $[X]$ No [ ] Not Required [ ] \\
EPCRA 313: Toxic Release Inventory Reporting & Yes [X] No [ ] Not Required [ ] \\
\hline${ }^{a}$ Extremely Hazardous Substances & \\
${ }^{b}$ Material Safety Data Sheet & \\
\hline
\end{tabular}

\section{Natural Resource Trusteeship \& Natural Resources Damage Assessment}

Executive Order 12580, Section 2(d), appoints the Secretary of Energy as the primary Federal Natural Resource Trustee for natural resources located on, over, and under land administered by DOE. Natural resource trustees act on behalf of the public when natural resources may be injured, destroyed, lost, or threatened as a result of the release of hazardous substances. In the case of the INEEL, other potential natural resource trustees with possible jurisdiction over trust resources are the state of Idaho, Department of Interior (Bureau of Land Management and U.S. Fish and Wildlife Service), and the ShoshoneBannock Tribes.

Past releases of hazardous substances resulted in the INEEL's placement on the National Priorities List. These same releases created the potential for injury to natural resources. DOE is liable under CERCLA for damages to natural resources resulting from releases of hazardous substances to the environment. The Environmental Restoration Program is attempting to coordinate with DOE-ID co-trustees on any INEEL Natural Resource Damage Assessment issues arising as a result of the comprehensive RI/FS study for each WAG.

In April 1995, the INEEL management and operations (M\&O) contractor and the Environmental Science and Research Foundation wrote a guidance manual for conducting screening level ecological risk assessments [Reference 2-1]. The manual was developed to streamline and standardize the ecological assessment process at the INEEL. It supports DOE schedules and milestones in the Federal Facility Agreement and Consent Order for carrying out RI/FS activities at the INEEL.

Although the ecological risk assessment is a separate effort from the Natural Resources Damage Assessment, it is anticipated that the ecological assessment performed for CERCLA remedial actions can be used to help resolve many natural resource issues among trustees as well. The regulation allows for this substitution [Reference 2-2].

\section{Clean Air Act}

The Clean Air Act set standards for ambient air quality and for emission of hazardous air pollutants. EPA is the federal regulatory agency of authority, but States may administer and enforce provisions of the Act by obtaining EPA approval of a State Implementation Plan. Idaho has been delegated such authority.

The Idaho air quality program is primarily administered through the permitting process. Potential sources of air pollutants are evaluated against regulatory criteria to determine if the source is specifically exempt from permitting requirements, and if the source's emissions are significant or insignificant. If emissions are 
determined to be significant, several actions may occur:

- self-certification that emissions are below any trigger level necessitating action by a regulatory agency;

- request for a permit applicability determination from the regulatory agency;

- request for a Permit to Construct; and

- request for a Permit to Construct for sources of significant emissions through a Prevention of Significant Deterioration analysis.

Permitting actions for potential sources of air pollutants are discussed in Section 2.3.

Title V Operating Permit. Title V of the 1990 Clean Air Act Amendments required the EPA to develop a federally-enforceable operating permit program for air pollution sources to be administered by the state and/or local air pollution agencies. The EPA promulgated regulations in July 1992 that defined the requirements for state programs. Idaho has promulgated regulations and EPA has given interim approval of the Idaho Title V Operating Permit program.

The INEEL Title V Air Operating Permit Application was submitted to the Idaho Division of Environmental Quality on July 28, 1995. The permit application was declared "administratively complete" on December 22, 1995. The regulatory technical review of the application is not anticipated to begin until spring of 2001. An updated application is to be scheduled in October of 2000. An emission inventory of sources of air pollutants is conducted annually and submitted to the regulatory agency. In addition, the INEEL prepared an addendum to the Title $\mathrm{V}$ application that updates emission sources.

Efforts are ongoing to evaluate release points and to ensure such sources are adequately described in existing permits and in the Title $V$ application. A database which identifies all applicable air quality requirements was developed in 1997. The database will support the Title V Operating Permit, helping to identify requirements and to develop strategies for ensuring compliance.

\section{National Emission Standards for Hazardous Air Pollutants}

In June 1999, DOE-ID submitted the 1998 INEEL National Emission Standards for Hazardous Air Pollutants - Radionuclides report to EPA, DOE-Headquarters, and state of Idaho officials. Using the CAP-88 computer model, the hypothetical maximum individual effective dose equivalent to a member of the public resulting from 1998 INEEL airborne radionuclide emissions (monitored, unmonitored, and diffuse sources) was $0.007 \mathrm{mrem} / \mathrm{yr}$. This dose was 0.08 percent of the regulatory standard of $10 \mathrm{mrem} / \mathrm{yr}$. The 1998 calculations with this code are discussed further in Chapter 8 , Dose to the Public.

In addition to the radiological program, the M\&O contractor operates an asbestos program. All renovations or demolitions of structures that involve asbestos must satisfy requirements of 40 CFR 61, Subpart M. During 1998, 22 non-scheduled renovation operations were carried out involving amounts less than the EPA threshold. There were 54 scheduled renovation or demolition operations that required EPA notifications (amounts above the EPA threshold); of these, 43 were $M \& O$ contractor operations, and 11 were operations of subcontractors.

\section{Clean Water Act}

The Clean Water Act, passed in 1972, established goals to control pollutants discharged to U.S. surface waters. Among the main elements of the Act are effluent limitations set by the EPA for specific industry categories and water quality standards set by states. The Clean Water Act also provided for the National Pollutant Discharge Elimination System (NPDES) permit program, requiring permits for discharges from a point source into surface waters. DOE was issued NPDES storm 
water general permits for - the discharge of storm water from industrial and construction activities at the INEEL in 1993.

Clean Water Act Section 404 Permits. In October 1994, the U.S. Army Corps of Engineers granted a 10-year Section 404 permit that authorizes DOE-ID to discharge dredge and fill material associated with the excavation of soil material in Spreading Area B. Borrow activities have ceased in this area since then. Currently, Spreading Area B is undergoing restoration activities including recontouring and revegetation.

Spill Prevention, Control, and Countermeasure Plans. Only the Test Area North, Idaho Nuclear Technology and Engineering Center (INTEC), and Radioactive Waste Management Complex require Spill Prevention, Control, and Countermeasure Plans. The INEEL facilities were evaluated in 1998 in accordance with 40 CFR 112 . The determination was made that all other facilities remain exempt. The plans were reviewed and updated as necessary.

\section{National Pollutant Discharge Elimination System (NPDES) Point Source Discharge Permits}

A NPDES permit application is on file with EPA Region 10 for minor discharges from INTEC production wells to the Big Lost River. INTEC is required to comply with Idaho water quality standards for these discharges.

Storm Water Discharge Permits for Industrial Activity. A modified NPDES storm water multi-sector general permit for industrial activities was published in 1998. The INEEL Storm Water Pollution Prevention Plan (SWPPP) for Industrial Activities [DOE/ID-10431] was implemented in 1993. The plan provides for baseline and tailored controls and measures to prevent pollution of storm water. Annual evaluations are conducted by the SWPPP team to determine compliance with the plans and the need for revision.
The Environmental Monitoring Unit of the M\&O contractor monitors storm water in accordance with the permit requirements and with DOE Orders. Results from this monitoring in 1998 are provided in Chapters 4 and 5.

The National Oceanic and Atmospheric Administration (NOAA) Air Resources Laboratory provides identification and notification of storm events. Storm water pollution prevention training is provided to INEEL personnel in accordance with the permit requirements.

Storm Water Discharge Permit for Construction Activity. INEEL's General Permit for Storm Water Discharges from Construction Sites was issued in June 1993. The permit was issued for five years and was set to expire on May 18, 1998. DOE-ID and the M\&O contractor submitted a Notice of Intent to EPA on May 12, 1998 in order to renew the permit for another five years. The INEEL Storm Water Pollution Prevention Plan for Construction Activities (DOE/ID-10425) was distributed in January 1994. The plan provides for measures and controls to prevent pollution of storm water. Worksheets are completed for construction projects and are appended to the plan. Inspections of construction sites are performed in accordance with permit requirements. The NOAA Air Resources Laboratory provides identification and notification of storm events. Under the permit for construction activities, storm water monitoring is not a requirement.

\section{Executive Order 11990 - Protection of Wet- lands}

The Big Lost River Sinks are the only area of the INEEL identified as jurisdictional wetlands. The U.S. Fish and Wildlife Service National Wetlands Inventory map is used to identify potential jurisdictional wetlands and non-regulated sites with ecological, environmental, and future development significance. Currently, there are no identified operations at the INEEL that have a significant impact on jurisdictional wetlands. However, cattle grazing is 
conducted by private parties in the Big Lost River Sinks area under Bureau of Land Management permits.

\section{Executive Order 11988 - Floodplain Man- agement}

During 1998, the U. S. Geological Survey completed "Preliminary Water-Surface Elevations and Boundary of the 100-Year Peak Flow in the Big Lost River at the Idaho National Engineering and Environmental Laboratory." This report presents simulated water-surface elevations for a hypothetical 100-year peak flow (USGS Water Resources Investigations Report 98-4065) [Reference 6-4].

\section{State of Idaho Wastewater Land Applica- tion Permits}

DOE-ID has applied for state of Idaho Wastewater Land Application Permits for all existing land application facilities (e.g., percolation ponds and sewage treatment irrigation systems), and four permits have been issued. Applications for Wastewater Land Application Permits have been submitted to the Idaho Division of Environmental Quality for the Water Reactor Research Test Facility Sewage and Process Ponds at Test Area North (TAN) and the Test Reactor Area (TRA) Chemical Waste and Cold Waste Ponds. The Argonne National Laboratory-West (ANL-W) Industrial Waste Pond and Conveyance Ditches application was submitted by DOE-Chicago Operations Office to the state of Idaho. An application for the Naval Reactors Facility Industrial Waste Ditch has also been submitted to the state for review.

\section{Resource Conservation and Recovery Act (RCRA)}

RCRA establishes regulatory standards for generation, transportation, storage, treatment, and disposal of hazardous waste. The state of Idaho is authorized by EPA to regulate hazardous waste and the hazardous component of mixed waste at the INEEL. Mixed wastes contain both radioactive and hazardous materials. Radioactive wastes not containing hazardous materials are regulated by the Atomic Energy Act as administered through DOE Orders.

Notice of Violation (NOV). On August 21, 1997, DOE received an NOV from the Idaho Division of Environmental Quality. The alleged violations stem from a November 18, 1996 inspection and cover four main areas: 1) releases of hazardous waste at TRA, 2) mismanagement of hazardous waste with the mercury retort, 3) waste determinations at the Auxiliary Reactor Area and 4) waste determination and management at INTEC. DOE-ID and the M\&O contractor received a draft NOV consent order in July 1998, which is currently under negotiation. A final NOV consent order is expected in early 1999.

Closure Plans. The state of Idaho approved the closure plans of the following units for eventual removal from the Part A permit (verification of closures is pending):

- Certified and Segregated Building at the Radioactive Waste Management Complex (RWMC), August 1998; and

- Air Support Building II at RWMC, August 1998.

Reports. As required by the state of Idaho, INEEL submitted the Idaho Hazardous Waste Generator Annual Report for 1998. The report contains information on waste generation, treatment, recycling, and disposal activities at INEEL facilities for 1998.

DOE-ID submitted the INEEL 1998 Affirmative Procurement Report to EPA by December 1,1998 , as required by Section 6002 of RCRA and Executive Order 13101 . This report provides information on the INEEL's procurement of products with recycled content.

The INEEL RCRA permit for the Hazardous Waste Storage Facility at CFA and some areas at ANL-W requires submittal of an annual certification to the Idaho Division of Environmental 
Quality (DEQ) that the INEEL has a waste minimization program in place to reduce the volume and toxicity of hazardous waste. The certification was submitted on July 1, 1998.

A 45-day Notification for 1998 Treatability Studies was submitted to the DEQ in January 1998 in lieu of the notification normally provided in the DOE Annual Report on Treatability Studies due to planned start dates. In October 1998, a similar notification was submitted for treatability studies planned for 1999. Treatability Studies, as defined by the regulation [Reference 2-3], are those in which a hazardous waste is subjected to a treatment process to determine:

- Whether the waste is amenable to the treatment process;

- what pretreatment, if any, is required;

- The optimal process conditions needed to achieve the desired treatment;

- The efficiency of a treatment process for a specific waste or wastes; and

- The characteristics and volumes of residuals from a particular treatment process.

The notifications briefly describe the types of studies performed on both hazardous waste and mixed waste, and the quantities of waste used in the studies. A "Treatability Study" is not a means to commercially treat or dispose of hazardous waste.

\section{Federal Facility Compliance Act}

The Federal Facility Compliance Act, which amends RCRA, requires the preparation of site treatment plans for the treatment of mixed wastes at DOE facilities that store or generate mixed wastes. Mixed waste contains both hazardous and radioactive components. The INEEL Site Treatment Plan (STP) was published on October 31, 1995. DOE and DEQ developed a consent order that provides the legal framework for implementing the STP. By November 1, 1995, both DOE and DEQ had signed the consent order, thereby implementing the STP. See Section 3.2 for more information.

In November 1998, the annual STP report was submitted to the state for review, public review, and final approval. In January 1999, the state approved the report. In 1998, the INEEL treated 79 cubic meters of mixed waste from offsite sources.

\section{National Environmental Policy Act (NEPA)}

NEPA requires federal agencies to consider and analyze potential environmental impacts of proposed actions and explore appropriate alternatives to mitigate those impacts, including a "no action" alternative. Agencies are required to inform the public of the proposed actions, impacts, and alternatives and consider public feedback in selecting an alternative. DOE implements NEPA according to procedures in 10 CFR 1021 and assigns authorities and responsibilities according to DOE Order 451.1. Processes specific to DOE-ID are set forth in its NEPA Internal Scoping Procedures, Quality Program Plan, and Public Participation Plan. The DOE-ID NEPA Compliance Officer and NEPA Planning Board implement the process.

\section{Environmental Impact Statements (EIS)}

Advanced Mixed Waste Treatment Project Environmental Impact Statement. The Draft EIS was published in July 14, 1998 . Three public meetings were held - one in Idaho Falls on August 18, 1998 and two in Twin Falls on August 20 and 21, 1998. The comment period on the Draft EIS, originally scheduled to end September 11, 1998 was extended to September 26,1998 . The Final EIS is expected to be published in early February 1999. For more information, refer to Section 3.2 of this report.

High-Level Waste Treatment and Facilities Disposition. A Notice of Intent was published and public scoping was conducted in 1997. The current schedule is to issue a Draft EIS in 
April 1999 and a Final EIS in November 1999. See Section 3.2 of this report for more information.

\section{DOE-ID Application for Nuclear Regulatory Commission (NRC) Licensing of an Inde- pendent Spent Fuel Storage Installation} (ISFSI). The reactor core debris from the Three Mile Island (TMI) nuclear reactor accident is currently stored under water at an INEEL TAN facility. DOE-ID prepared an Environmental Assessment (EA) titled "Test Area North Pool Stabilization Project." The EA analyzed removal of the core debris from current storage, construction of an interim dry storage facility on the INEEL at INTEC, the associated transportation of the core debris from TAN to INTEC, and closure of the storage pool. After public review of the EA, a Finding of No Significant Impact (FONSI) was issued May 6, 1996. In 1997, the proposed action analyzed in the $1996 \mathrm{EA}$ was modified to include a drying process for the core debris. An "update" EA was prepared and, after public review, a second FONSI was issued August 25, 1997. DOE-ID applied to the NRC for a license to construct and operate an ISFSI for the interim dry storage of the TMI core debris. Under NRC's NEPA implementing procedures an EIS must be prepared to license an ISFSI. In accordance with its procedures, NRC prepared and issued a Final EIS "For the Construction and Operation of an Independent Spent Fuel Storage Installation to Store the Three Mile Island Unit 2 Spent Fuel at the Idaho National Engineering and Environmental Laboratory (Docket No. 72-20)." The notice of availability for this EIS was published March 17, 1998.

\section{Safe Drinking Water Act}

The INEEL operates 12 active public water systems, two of which serve NRF and ANL-W. All INEEL facilities performed sampling of drinking water as required by the state and EPA.
The Safe Drinking Water Act was reauthorized on August 6, 1996. It establishes primary standards for drinking water delivered by systems supplying drinking water to 15 or more connections or 25 individuals for at least 60 days per year. The INEEL drinking water supplies meet those criteria and are classified as either nontransient noncommunity or transient noncommunity systems.

\section{Toxic Substances Control Act}

The Toxic Substances Control Act, which is administered by EPA, requires testing and regulation of chemical substances that enter the environment. The Act supplements sections of the Clean Air Act, the Clean Water Act, and the Occupational Safety and Health Act. Compliance with the Act at the INEEL is primarily directed toward management of polychlorinated biphenyls (PCBs).

Storage of PCB-Contaminated Materials. DOE-ID continues to store radioactively contaminated PCBs at the INEEL. Negotiations between DOE and EPA resulted in a complexwide agreement (May 8, 1996) for storage longer than one year. DOE-ID and EPA Region 10 are in the process of resolving issues associated with one-year storage of these materials.

\section{Federal Insecticide, Fungicide, and Rodenticide Act (FIFRA)}

FIFRA governs the registration and use of pesticides (i.e. fungicides, herbicides, insecticides, and rodenticides). The INEEL complies with the Act's requirements pertaining to storage and application of pesticides. A review of the INEEL FIFRA program was conducted in June 1998, during which two regulatory inspectors from the state of Idaho Department of Agriculture visited the Site at the invitation of DOE-ID in order to assist in the program review. The purposes of the visit were to open a dialogue between INEEL personnel and the regula- 
tory authority for FIFRA; to review pesticide storage areas and proper management protocols; to ask professional opinions about using a restricted-use pesticide at Test Area North; and to evaluate the pesticide management program at the INEEL. The visit was beneficial both for INEEL and the inspectors. The inspectors found that program documentation, procurement processes, and pesticide controls are in order and complete.

The inspectors returned to the Site in December 1998 to investigate the potential misapplication of a pesticide in June 1998 that appeared to result in the death of a large number of evergreen trees. The inspectors interviewed INEEL personnel, took soil and tree needle samples, and photographed the dead trees. A report is expected in 1999.

\section{National Historic Preservation Act}

Preservation of historic properties on lands managed by DOE is mandated under Section 106 of the National Historic Preservation Act. The Act requires that when any federal undertaking will have an adverse effect on historic property, the cognizant federal agency must enter into an agreement with the State Historical Preservation Officer for the purpose of mitigating those adverse effects.

A comprehensive draft Historic Context of the INEEL was prepared in 1997 and is currently under review by the State Historical Preservation Officer. This Historic Context contains a historic evaluation of all properties built on the INEEL under the DOE-ID's authority, and provides the background with which to assess their historic significance. It will be used to guide a more comprehensive approach to managing the preservation and documentation of buildings scheduled to be modified or dismantled.

Draft Tribal Consultation Procedures were developed in partnership with the ShoshoneBannock Tribes. These procedures provide clarity and guidance to ensure continued good communication between the Tribes, DOE, and the $M \& O$ contractor regarding cultural resource management on the INEEL. The Procedures are an integral component of the two-year Agreement-in-Principle between DOE-ID and the Tribes, signed in June 1998. DOE-ID also organized and hosted a first of its kind Cultural Resource training course. The course was specifically organized to allow for participation and representation of tribal representatives from several tribes in the Northwest, government agencies, contractor personnel.

\section{Native American Grave Protection and Repatriation Act (NAGPRA)}

The INEEL is located on the aboriginal territory of the Shoshone people. The ShoshoneBannock Tribes are major stakeholders in INEEL activities. They are particularly concerned with how the remains of their ancestors and culture are treated by DOE-ID and its contractors. NAGPRA provides for the protection of Native American remains and the repatriation of human remains and associated burial objects. Repatriation refers to the formal return of human remains and cultural objects to the tribes with whom they are culturally affiliated.

In 1998, the Department of Interior released the Annual Report to Congress on Federal Archeological Activities for Calendar Year 1994-95. The Report addresses the archeological activities of all federal agencies. The Report features an article written by the DOE-ID Cultural Resources program highlighting the INEEL's successful management of an unanticipated discovery of human remains at the Power Burst Facility in 1994-95. The article, "Tribes and DOE Find Road to Cooperation," is the feature piece of the section of the report dealing with NAGPRA. The article was written in partnership with archeologists of the M\&O contractor and the ShoshoneBannock Tribes' cultural resource specialists. 


\section{Endangered Species Act}

The Environmental Science and Research Foundation conducts ecological research, field surveys, and NEPA evaluations regarding ecological resources. Particular emphasis is given threatened and endangered species and species of special concern identified by the U.S. Fish and Wildlife Service. Although sightings of wolves (Canis lupus), an endangered species, on the INEEL have been sporadically reported since 1993 , none were reported during 1998. Nor were any Ute's ladies tresses (Spiranthes diluvialis) reported. It is unlikely suitable habitat (wet meadows) exists on the INEEL long enough each year to support this threatened species. Research and monitoring continued on several species of special biological, economic, and social concern, including Townsend's big-eared bat (Corynorhinus townsendii), pygmy rabbit (Brachylagus idahoensis), burrowing owl (Speotyto cunicuilaria), sage grouse (Centrocercus urophasianus), elk (Cervus elaphus) and pronghorn antelope (Antilocapra americana). Summaries of these and other research projects can be found in Reference 2-4.

\subsection{OTHER MAJOR ENVIRONMENTAL ISSUES AND ACTIVITIES}

\section{Litigation Issues}

Fort St. Vrain Litigation. On February 9, 1996, DOE and the Public Service Company of Colorado signed an out-of-court settlement that allows continued safe storage of spent nuclear fuel from the Fort St. Vrain power reactor near Platteville, Colorado, until a permanent repository becomes available. The agreement meets one of the requirements of the October 1995 spent fuel agreement between DOE, the state of Idaho, and the U.S. Navy. Under the agreement, spent nuclear fuel from Fort St. Vrain can only be shipped to the INEEL if a permanent repository or interim storage facility located outside Idaho has been opened and is accepting fuel from the INEEL. In that case, spent nuclear fuel from Fort St. Vrain could be shipped to the INEEL for the purpose of preparing it for disposal or storage out-of-state. The Nuclear Regulatory Commission (NRC) transferred the NRC license from Public Service Company to DOE in June of 1999.

The out-of-court settlement between DOE and the Public Service Company resolves the company's claims against DOE emanating from a 1965 cooperative agreement among the DOE, Gulf General Atomic, and the Public Service Company under which DOE was to receive and dispose of Fort St. Vrain spent fuel. The Public Service Company claimed the contract obligated DOE to receive spent nuclear fuel from the Fort St. Vrain reactor for storage. However, DOE was unable to fulfill the contract because of the legal challenges to spent nuclear fuel storage at the INEEL. The utility company subsequently constructed and now operates a NRC-licensed fuel storage facility located adjacent to the former Fort St. Vrain power plant.

In lieu of accepting the spent nuclear fuel for storage in Idaho, DOE has taken title to the spent fuel and has paid the Public Service Company $\$ 16$ million to settle the claim. Public Service Company personnel continued to manage the fuel for DOE under its NRC license until the NRC license was transferred to DOE in June of 1999. Title to the real estate was transferred to DOE in July of 1999.

Pit 9 Project. In the summer of 1997, Lockheed Martin Advanced Environmental Systems (LMAES) and Lockheed Martin Corporation began work slowdown on the Pit 9 project. On February 27, 1998 Lockheed Martin Idaho Technologies Company (LMITCO) issued a cure notice to LMAES, the subcontractor chosen in 1994 for the Pit 9 Comprehensive Demonstration Project. The Pit 9 project was intended to provide information about methods for retrieval and treatment of buried transuranic waste and information on the status of contaminant migration and waste 
characteristics. LMAES responded to the cure notice on April 13, 1998. On June 1, 1998 the subcontract with LMAES was terminated for default after LMITCO's review of LMAES's response to the cure notice. After consideration of the points presented by LMAES in its response, LMITCO determined that LMAES had not met the requirements of the cure notice. LMITCO then took action to execute the work outlined in the Record of Decision on Pit 9 in accordance with an alternative plan submitted to the state of Idaho on September 30, 1997. At the time of termination, LMITCO had paid LMAES $\$ 54 \mathrm{M}$ under the subcontract. LMITCO requested return of the $\$ 54 \mathrm{M}$ due to LMAES default on the subcontract.

In late 1998, LMAES and its parent company, Lockheed Martin Corporation, filed a claim in Federal court against the United States government, requesting, among other things, that the subcontract default termination be converted to a convenience termination, thereby allowing LMAES to retain the $\$ 54 \mathrm{M}$ paid under the subcontract. A Department of Justice response to the claim is expected to be filed in early 1999. LMAES and Lockheed Martin Corporation also filed claim against LMITCO for over $\$ 211 \mathrm{M}$, including the $\$ 54 \mathrm{M}$ already paid. This claim was based upon alleged constructive changes to the subcontract terms, commercial impracticability of the project, unreasonable delay in the project, failure to cooperate with LMAES, misrepresentation or failure to disclose information, and mutual mistake. LMAES requested that LMITCO "sponsor" the claim to DOE. LMITCO is in the process of analyzing the claim in order to respond.

\section{Ground-Water Monitoring Program Activities}

The INEEL Ground-water Monitoring Plan establishes a programmatic framework for ensuring compliance with all state, federal, and DOE ground-water-related standards. In accordance with DOE Order 5400.1, the plan documents local and regional hydrologic regimes, known and potential sources of ground-water contamination at the INEEL, and the monitoring networks and sampling programs necessary to evaluate the effects of the INEEL's activities on the local and regional ground-water resources.

The INEEL Ground-water Monitoring Program was designed using a three-tiered approach which integrates "Regional," "Areaspecific," "Facility-specific," and "Unit-specific" monitoring networks. These networks are being installed and ground-water monitoring schedules are being implemented using a phased approach. The regional monitoring network is mostly in place and is being implemented by the United States Geological Survey (USGS) as part of their ongoing program, which has been conducted since 1949. The development of area-specific monitoring networks was initiated in 1993 and networks have been completed at the Auxiliary Reactor Area, Special Training Facility, PBF, and INTEC. Area-specific monitoring networks are being installed in accordance with the INEEL Ground-water Monitoring Plan implementation schedule. Unit- and facility-specific monitoring networks were designed to provide leak detection. These wells are designed, installed, and monitored on an as-needed basis.

In 1998, compliance ground-water monitoring was conducted at TAN and INTEC as required by the Wastewater Land Application Permit. Observational ground-water monitoring was conducted by the USGS in accordance with its Memorandum of Agreement with DOE-ID (see Section 6), and ground-water monitoring and characterization were conducted by the Environmental Restoration program in accordance with the INEEL Federal Facility Agreement and Consent Order. 


\section{Health Studies}

DOE and the INEEL have a medical surveillance program to monitor the health of current workers. The program is based on routinely collected health data, such as recordable injuries and illnesses specified by the Occupational Health and Safety Administration. The program will help identify emerging health issues at the INEEL.

A medical surveillance program for former workers at the INEEL was initiated in 1997. The program, required by Section 3162 of Public Law 102-484, will evaluate the long-range health conditions of former employees who may have been subject to significant health risks from exposure to hazardous substances as a result of their employment at the INEEL. A Phase I pilot project was completed in October 1998 by a group of investigators consisting of the Paper, Allied-Industrial, Chemical, and Energy Workers International Union; Mt. Sinai School of Medicine; the University of Massachusetts at Lowell; and Alice Hamilton College. The pilot project resulted in findings that former INEEL workers have had significant exposure to pulmonary toxins, carcinogens, renal toxins, neurotoxins, hepatotoxins, and noise; epidemiological studies at INEEL are lacking; and that workers are concerned about previous exposures and are interested in a medical screening and education program. The findings support a targeted medical surveillance program that will be mounted in Phase II beginning in 1999.

Researchers from the Boston University School of Public Health, in cooperation with the National Institute of Occupational Safety and Health (NIOSH), are investigating the effects of workforce restructuring (downsizing) in the nuclear weapons industry. The health of displaced workers will also be studied.

In August 1996, DOE and the Department of Health and Human Services revised their Memorandum of Understanding under which the Department of Health and Human Services conducts and manages all epidemiological studies at DOE facilities. Two study areas, dose reconstruction and worker epidemiology, are discussed below.

The Centers for Disease Control and Prevention (CDC) have established a public advisory group, the INEEL Health Effects Subcommittee. The Subcommittee meets four times a year, usually in different cities in Idaho. This group will provide recommendations to the CDC and to the Agency for Toxic Substances and Disease Registry (ATSDR) regarding INEEL health studies performed under two Memorandums of Understanding.

INEEL Dose Reconstruction Study. The INEEL Environmental Dose Reconstruction Project is being conducted by the National Center for Environmental Health of the CDC. Phase 2 began in 1996 with the start of a task to determine the feasibility of estimating doses to the offsite public from toxic chemicals released from the INEEL. A similar task for radionuclides began near the end of 1997 and continued in 1998.

Epidemiological Study of Workers at the INEEL. The INEEL Epidemiological Study of Workers, which will evaluate patterns of mortality in all workers at the INEEL since 1949, is being conducted by NIOSH of CDC. NIOSH is conducting an all-cause cohort mortality study and will evaluate the feasibility of a prospective cancer incidence study among INEEL employees. Exposures of interest are external ionizing radiation and a variety of chemicals. The first phase of the study, analysis of standardized mortality ratios, is planned for completion by 1999.

Phase 1 of the Paper, Allied-Industrial, Chemical, and Energy Workers International Union (PACE) Worker Protection Program "medical surveillance of former INEEL workers" was completed in October 1998. Phase I (needs assessment) indicated the need to initiate Phase II of the program which includes medical 
examinations and educational workshops, as well as gathering additional health risk data. Under a NIOSH cooperative agreement, the epidemiological evaluation of childhood leukemia and paternal exposure to ionizing radiation now includes the INEEL, as well as other DOE sites.

CERCLA Health Assessment. The ATSDR began a Health Assessment of the INEEL as required by CERCLA for all sites listed on the National Priorities List. The focus of the Health Assessment is to provide information that would further the goal of preventing and mitigating exposures to hazardous substances released to the environment. The majority of the Health Assessment is expected to be completed in 1999 and is funded by DOE.

\section{Environmental Occurrences}

Several small spills occurred at the INEEL during 1998 that were not reportable under environmental regulations. These included small releases of diesel fuel, transmission fluid, sulfuric acid, nitric acid, ethylene glycol, and oil.

During calendar year 1998 , there were four reportable releases. Notifications were made in accordance with DOE and CERCLA requirements. At CFA, 110 gallons of oil were released due to an improperly secured nozzle. The other releases occurred at TRA: 15 gallons of wastewater containing RCRA constituents from a dewatering line dislodged from a sump; 120 gallons of PCB-contaminated water from a damaged valve on a mobile trailer tank; and 240 pounds of the herbicide Diuron accidentally applied too close to trees.

\section{Environmental Oversight and Monitoring Agreement (EOMA)}

The Environmental Oversight and Monitoring Agreement between DOE-ID, DOE-Naval Reactors Idaho Branch Office, and the state of Idaho maintains the state's program of independent oversight and monitoring established under the first agreement creating the INEEL State
Oversight Program (Oversight Program). The main objectives as established under the second five-year agreement are to

- assess the potential impacts of present and future DOE activities in Idaho;

- assure citizens of Idaho that all present and future activities in Idaho are protective of the health and safety of Idahoans and the environment; and

- communicate the findings to the citizens of Idaho in a manner that provides them the opportunity to evaluate potential impacts of present and future DOE activities in Idaho.

Oversight Program activities produced many accomplishments in 1998, due in large part to a well-coordinated working relationship with DOE, INEEL contractors, the Shoshone-Bannock Tribes, USGS, NOAA, and Idaho State University.

Monitoring and Surveillance Committee (MSC). The INEEL MSC was formed in March 1997 and holds monthly meetings to coordinate activities between groups involved in INEEL-related onsite and offsite environmental monitoring. This standing committee brings together representatives of DOE (Idaho, Chicago, and Naval Reactors), the M\&O contractor, ANL-W, INEEL contractors, ShoshoneBannock Tribes, DEQ, Oversight Program, NOAA, USGS, and the Environmental Science and Research Foundation. The MSC has served as a valuable forum to review monitoring, analytical, and quality assurance methodologies, to coordinate efforts, and to avoid unnecessary duplication.

Environmental Surveillance Program. The Environmental Surveillance Program is intended to verify and supplement existing surveillance programs operated by INEEL contractors. The program's approach is designed to accomplish environmental verification.

In 1998, the Oversight Program targeted improved coverage, efficiency, and reliability of sampling by installing atmospheric tritium 
samplers at Craters of the Moon National Monument and Fort Hall. It also focused on more rigorous estimates of radiological and non-radiological background in order to enhance the understanding of possible INEEL impacts. Enhanced collaborative efforts between the surveillance group and other Oversight Program groups, such as impact assessment and emergency response, were also pursued in order to develop and promote new avenues of data applications.

\section{Emergency Response and Preparedness}

Program. The EOMA requires emergency preparedness assistance to local authorities. DOE has assisted the Oversight Program in establishing a statewide Interagency Planning Group. The group provides a process for coordinating emergency preparedness issues and concerns among the various state agencies as well as increased communication among the organizations. A five-phase radiological emergency response plan and emergency response training has been cooperatively established with the State Oversight Program to assist the local governments to meet local emergency response needs. The community monitoring stations have helped enhance the monitoring parameters and locations of meteorological conditions for use in emergency planning as well as emergency response. This information is available to the state of Idaho as well as the local emergency response personnel for use in actual emergencies and for use in drills and exercises.

Impact Assessments Program. The Impacts Assessment Program produces scientific validation through independent risk assessment of current and future operations specific to idaho. A collaborative effort improves and scientifically validates DOE's processes. The activity allows the state and DOE to more effectively and efficiently plan future needs in surveillance and emergency response.

\section{Citizens Advisory Board}

The INEEL Citizens Advisory Board, formerly called the Site Specific Advisory Board, was formed in March 1994. Its charter is to provide input and recommendations on environmental management strategic decisions that impact future use, risk management, economic development, and budget prioritization activities.

The Board has produced 65 recommendations to date. In 1998, 20 recommendations were made including:

- Fiscal Years 1999 and 2000 Budget Requests

- Implementation of CERCLA at INEEL

- Proposed Plan for WAG 1 (TAN)

- Draft Accelerating Cleanup: Paths to Closure

- Notice of Intent to conduct an analysis of policy regarding disposal of LLW and MLLW at commercial facilities under DOE Order $5820.2 \mathrm{~A}$

- Draft EIS for the Advanced Mixed Waste Treatment Project

- Comments and suggestions on the draft Plutonium Fact Sheet

- Draft RCRA Part B Permit for the Waste Isolation Pilot Plant

- Integration of Shoshone-Bannock Tribes' Perspectives Regarding Risk Assessment

- Recommendation Extensions to DOE Public Comment Periods

- Intermodal Transport of LLW to the Nevada Test Site

- Transfer of Heat Source/Radioisotope Thermoelectric Generator Assembly and Test Operations EIS

- Proposed Production of Plutonium-238 for Use in Advanced Radioisotope Power Systems for Future Space Missions EIS

- Draft Request for Proposal for Managing and Operating the INEEL 
- Proposed Plan for Remedial Actions at WAG 3 (INTEC)

- Proposed Soils Repository at INEEL

- Surplus Plutonium Disposition Draft ElS

- Proposed Strategy for Remedial Actions at WAG 3 (INTEC)

- Proposed Plan for WAG 8 (Naval Reactors
Facility)

- Proposed Plan for WAG 9 (ANL-W)

\subsection{Permits}

Permits granted to the INEEL in 1998 and those for which applications have been submitted are summarized in Table 2-2.

Table 2.2 Permit Summary for the INEEL (1998)

\begin{tabular}{|c|c|c|c|}
\hline Media/Permit Type & Issuing Agency & Granted & Pending \\
\hline \multicolumn{4}{|l|}{ Air } \\
\hline Self-Certify & None & 16 & 0 \\
\hline Permit to Construct & $D E Q$ & 3 & 1 \\
\hline Exempt/PADa & $D E Q$ & 8 & 4 \\
\hline NESHAPS ${ }^{\circ}$ & EPA Region 10 & 0 & 1 \\
\hline Operating Permit & $D E Q$ & 0 & 1 \\
\hline \multicolumn{4}{|l|}{ Ground Water } \\
\hline Injection Well & Dept of Water Resources & 8 & 0 \\
\hline Well Construction & Dept of Water Resources & 1 & 0 \\
\hline \multicolumn{4}{|l|}{ Surface Water } \\
\hline NPDES - Point Source & EPA Region 10 & 0 & 1 \\
\hline NPDES - Storm Water & EPA Region 10 & 2 & 1 \\
\hline Wastewater Land Application & $D E Q$ & 4 & 5 \\
\hline 404 Permit & Corps of Engineers & 1 & $O$ \\
\hline Industrial Waste Acceptance & City of Idaho Falls & 16 & 1 \\
\hline \multicolumn{4}{|l|}{ RCRA } \\
\hline Part A & State of Idaho & 1 & $O$ \\
\hline Part $B^{c}$ & State of Idaho & $8^{c}$ & $36^{6}$ \\
\hline
\end{tabular}




\section{Chapter 3 \\ Environmental Program Information}

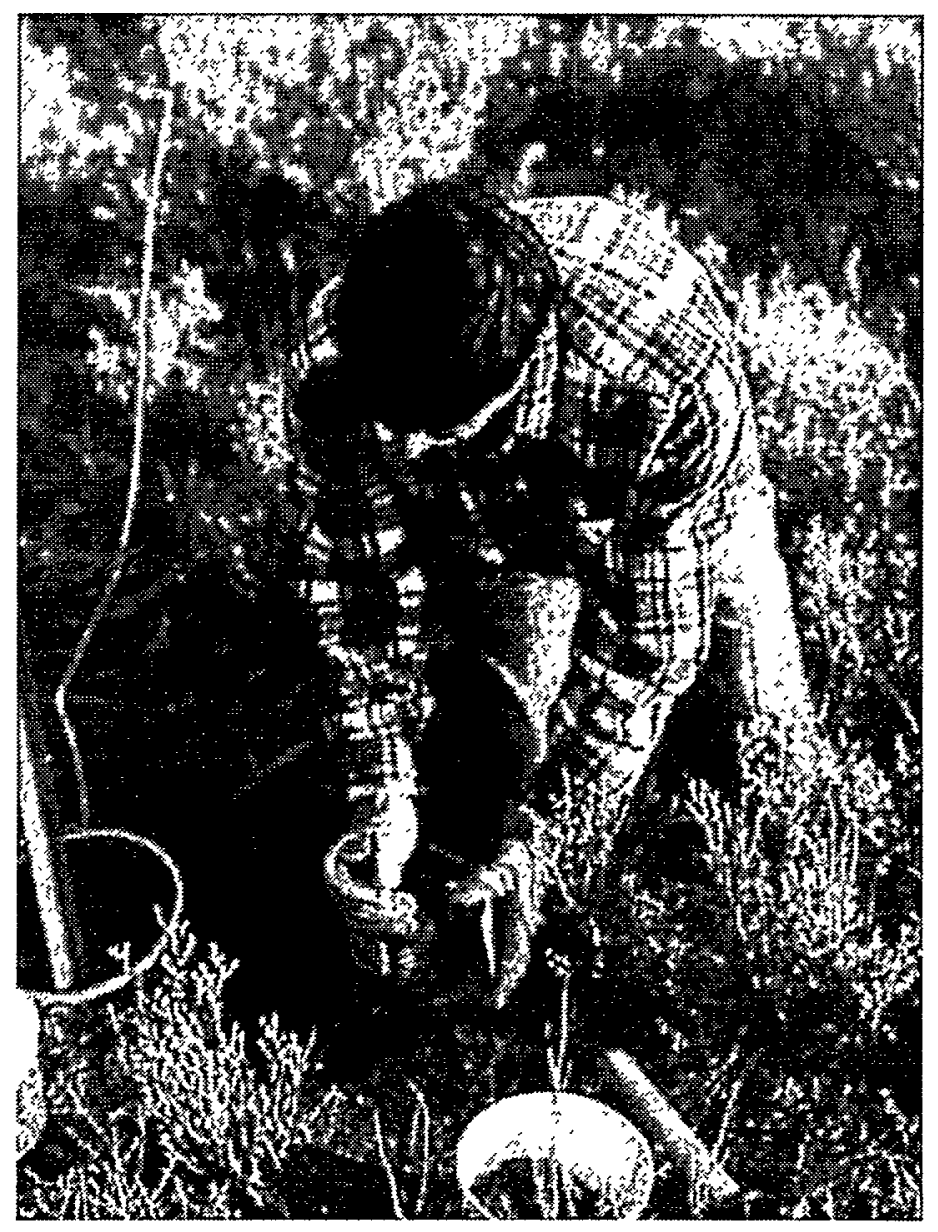




\section{ENVIRONMENTAL PROGRAM INFORMATION}

\subsection{ENVIRONMENTAL MANAGEMENT SYSTEM}

The DOE Idaho Operations Office (DOE-ID) and the INEEL management and operating (M\&O) contractor continued to make progress on the effort initiated in 1997 to develop and implement an INEEL-wide Environmental Management System (EMS). The EMS will meet the requirements of ISO 14001, an international voluntary standard for environmental management systems. This standard is being vigorously embraced worldwide and within the DOE complex. INEEL's goal for certification under ISO14001 demonstrates continued commitment to improved environmental performance to regulators, the public, and the international business community.

An EMS provides an underlying structure to make the management of environmental activities more systematic and predictable. The EMS focuses on three core concepts: pollution prevention, environmental compliance, and continuous improvement. The primary system components are (1) Environmental Policy, (2) Planning, (3) Implementation and Operation, (4) Checking and Corrective Action, and (5) Management Review

In 1998, considerable progress was made toward the goal on joint DOE-ID/M\&O contractor IS014001 certification. Project development was initiated in July 1998 with the formation of a Steering Board and Core Team. Training and benchmarking were conducted and work was initiated on a project plan that will be completed in 2000. Environmental aspects were identified and ranked according to a newly created procedure and evaluations of records management and document control as they relate to EMS were initiated. All of this information as well as the EMS implementation schedule and other documents will be published on the INEEL web page in 1999.
This effort is being developed as part of the Integrated Safety Management System (ISMS) currently being implemented by DOE-ID and the $M \& O$ contractor. Both the EMS and ISMS are based on the "plan, do, check, act" concept; both involve work planning, analysis of hazards and impacts, operational controls, feedback, and continuous improvement. DOE-ID and the M\&O contractor already have in place many ISMS/EMS systems. A primary goal of both DOE-ID and the M\&O contractor is for work planning and execution to proceed with full consideration of environmental, safety, and health implications.

\subsection{ENVIRONMENTAL RESTORATION PROGRAM}

\section{Overview}

A common perception of environmental restoration investigative and remedial activities at DOE and other government sites is that all parts of the process are expensive and timeconsuming. However, during recent years, streamlining environmental restoration activities at the INEEL by DOE, the Environmental Protection Agency (EPA), and the state of Idaho has saved millions of dollars. This streamlining was possible due to the flexibility and management principles established under the Federal Facility Agreement and Consent Order (Agreement) such as:

- Making cleanup decisions as soon as sufficient data are present;

- Using existing data whenever possible;

- Avoiding duplication of analyses and documentation; and

- Matching the level of investigation to the level of complexity of each release site.

The Agreement was signed in December 1991 and since then, the INEEL has cleaned 
up sites containing asbestos, petroleum products, acids and bases, radionuclides, unexploded ordnance and explosive residues, polychlorinated biphenyls (PCBs), heavy metals, and other hazardous wastes. The INEEL Environmental Restoration Program has maintained significant progress in accomplishing its goals. As of December 1998, a tally of environmental restoration activities at the INEEL showed:

- 17 Records of Decision have been signed;

- 21 removal actions were completed;

- 5 major investigations were in progress;

- 4 interim actions were completed; and

- 8 final actions were completed or fully operational.

Comprehensive remedial investigation/ feasibility studies (RI/FS) are under way in Waste Area Groups 4, 7, and 10. The comprehensive investigations, which take an average of forty months to complete, accomplish the following:

- Determine the cumulative risks for an entire Waste Area Group by assessing the combined impact of all release sites within that group;

- Review assumptions used in each previous investigation, including "No Further Action" sites, Track 1 and 2 limited field investigations, Rl/FS, and interim actions;

- Identify data gaps and recommend actions such as field sampling or historical document research to resolve questions;

- Perform a feasibility study to evaluate remedial alternatives for the entire Waste Area Group;

- Develop a proposed plan presenting the alternatives and recommending a preferred alternative; and

- Develop a record of decision selecting the alternative and resolving public comments.

The general procedure for all comprehensive investigations begins with developing a
Work Plan outlining potential data gaps and release sites that may require more field sampling. When the investigation is complete, DOE, EPA and the State hold public comment meetings on the proposed cleanup alternative. During 1998, three comprehensive investigations were completed: Test Area North, Idaho Nuclear Technology and Engineering Center, and Power Burst Facility/Auxiliary Reactor Area. A summarized status of each Waste Area Group is published annually in the INEEL Report Supplement, "Annual Progress Report," available on the Internet at http://www.inel.gov/environment/em/or by calling 1-800-708-2680.

\section{Waste Area Group 1 - Test Area North}

Ground-water Remediation. Cleanup of the Test Area North (TAN) injection well began in 1993. The well was used from 1953 until 1972 to inject liquid wastes into the fractured basalt of the Snake River Plain Aquifer. The wastes included organic and inorganic compounds and low-level radioactive wastes combined with industrial and sanitary wastewaters. The resulting plume contaminated some of the drinking water wells used by TAN workers. The drinking water has been treated to meet drinking water standards, and untreated water is not accessible.

The final Rl/FS addressing the entire contamination plume was completed in 1994. The TAN groundwater final remedial action Record of Decision was approved in August 1995. The Groundwater Treatment Facility designed and constructed under a 1994 interim action has been in continuous operation since November 1996 and has since treated over 120.5 million liters (31.7 million gallons) of water. The remedy selected under the Record of Decision calls for containing the contamınated groundwater and reducing contamınation levels to below maximum contaminant levels withın 100 years. The decision also calls for the evaluation of new, innovative technologies, such as in situ 
bioremediation and in situ chemical oxidation, as enhancements to the current pump and treat operation.

A field test of bioremediation using a native microbe present in the subsurface was initiated in 1998. Lactate is injected into the ground to the microbes that break down trichloroethene (TCE). The test will be completed in 1999. Work was also started on a natural attenuation treatability study that will continue in 1999. A Field Evaluation Work Plan for in situ chemical oxidation was submitted to the State and EPA for review in 1998, with plans to start work in 1999 if the in situ bioremediation test fails.

Waste Area Group 1 Comprehensive RI/FS. This investigation began during 1995 . Eleven operable units and 94 potential release sites, including the $\mathrm{V}$-tanks (tanks containing hazardous, PCBs, and radioactive wastes) were evaluated during the final investigation. The $\mathrm{Rl} / \mathrm{FS}$ was finalized on November 14, 1997. A Proposed Plan describing this investigation was issued in February 1998. Input from the public and the INEEL Citizens Advisory Board resulted in withdrawal of this plan. A public focus group was formed to provide input to improve the plan while technical revisions were made in a Feasibility Study Supplement. In November 1998, a revised Proposed Plan and a Feasibility Study Supplement were issued, incorporating feedback from the focus group and the public. A Record of Decision of the comprehensive investigation, incorporating input received during the public comment period, is expected to be issued in September 1999. The Record of Decision will describe how nine contaminated sites will be remediated, including underground storage tanks, contaminated soil areas, a disposal pond, burn pits, a mercury spill area, and a fuel leak.

In 1998, a successful treatability study was performed to assess the feasibility of applying a modified in situ vitrification (ISV) technology to the TAN V-tanks. EPA accepts ISV as appropriate treatment technology for PCBs and other wastes that the $V$-tanks contain. A tank at the vendor's site in Richland, WA, which matched the dimensions of the V-tanks and contained inert materials, was melted using planar ISV. The test produced the expected results and demonstrated the feasibility of applying the technology to underground storage tanks. A bench-scale stabilization test using actual V-tank waste and suitable grouts was also conducted to select an appropriate solidifying material should grouting be selected as the final remedy.

\section{Waste Area Group 2 - Test Reactor Area}

Perched Water System. Perched water under the Test Reactor Area (TRA) is a zone of ground water standing on a relatively impermeable layer of clay 100 meters (328 feet) above the Snake River Plain Aquifer. It was formed over time by percolation from the TRA wastewater disposal ponds. Routine compliance monitoring has been conducted since 1993 to aid regulatory agencies in comparison of predicted and actual contaminant concentrations in the perched water.

Waste Area Group 2 Comprehensive RI/FS. The comprehensive RI/FS and Record of Decision were signed in December 1997, documenting remedial action to be taken at eight of the 55 potential release sites at TRA. The major contaminants of concern are metals, radionuclides, and organic chemicals such as PCBs. The statement of work and work plan for Remedial Design/Remedial Action were approved by the regulatory agencies in 1998 . Cleanup actions at the eight release sites will be begin in 1999 and are scheduled for completion in October 1999. Cleanup actions will consist of covering contaminated soil at three sites, excavating and disposing soil at one site, and implementing institutional controls and monitoring at all eight sites. 


\section{Waste Area Group 3 - Idaho Nuclear Tech- nology and Engineering Center}

Tank Farm. In 1998, DOE, EPA, and the state of Idaho agreed to investigate contaminated soil at the Idaho Nuclear Technology and Engineering Center (INTEC) tank farm as a separate remedial investigation and feasibility study. The tank farm consists of 20 tanks containing liquid wastes of varying quantities and associated equipment for waste transfer, monitoring, and control. This investigation will continue in 1999 and will result in a separate Record of Decision. An interim action of institutional controls will commence to minimize contaminant exposures and limit effects on soil and groundwater until a cleanup action is completed.

Waste Area Group 3 Comprehensive RI/FS. The major source of contamination at INTEC is the underground storage tanks that contain high-level waste generated from past spent nuclear fuel reprocessing activities. The site also has contaminated groundwater from a now sealed injection well, soils beneath buildings, and waste disposal ponds. The chief contaminants are radionuclides. A total of 95 sites of known or suspected contaminant releases were evaluated in the comprehensive Rl/FS (December 1997) and summarized in a Proposed Plan (October 1998). Forty-four of the 95 sites require cleanup; the majority of these sites will be addressed in the Record of Decision scheduled for issuance in August 1999. The Proposed Plan also included a preferred alternative that would create a large, onsite disposal facility at INTEC for cleanup-related waste from INEEL.

\section{Waste Area Group 4 - Central Facilities Area}

Simulated Calcine/Mercury-Contaminated Soil Removal Action. The materials associated with this project were excavated from a dry pond used in the 1950 s and 1960 s to dispose of materials from the Chemical Engineering Laboratory during development of a nuclear waste calcining process. The removal action summary report was issued in 1998.

Miscellaneous Sites 1997 Removal Action. This removal action involved five sites at the Central Facilities Area (CFA). Petroleum-contaminated materials, primarily soils, were cleaned up at three sites, and two dry wells from the other two sites were removed for disposal. A summary report was submitted to the state of Idaho and EPA on June 12, 1998 four months ahead of schedule.

Landfills I, II, and III Remedial Action. This action was completed in 1997, and routine ground-water monitoring and periodic maintenance are being performed as required by project documentation.

As specified in the Record of Decision for CFA Landfills I, II, and III, the remedy consisted of native soil covers, access controls such as fencing and signs, and environmental monitoring. Minimizing infiltration of water through the wastes that could facilitate migration of contaminants to the Snake River Plain Aquifer is the main purpose of the soil covers, which also mitigate direct contact with the wastes in the landfills.

Used as recently as 1984, the landfills accepted municipal-type and industrial wastes generated from INEEL operations. Wastes disposed to the landfills included cafeteria garbage, trash sweepings, weeds, grass, asphalt, asbestos, scrap lumber, and metal. DOE-ID, $E P A$, and the state of Idaho agreed to take action to reduce any potential of groundwater contamination from the landfills and risks associated with exposure to the waste.

Waste Area Group 4 Comprehensive RI/FS. A total of 13 operable units and 52 potential release sites are being examined during this investigation. The main sources of contamination are landfills, a waste disposal pond, a wastewater drainfield, and underground storage tanks. Major contaminants are metals, radionuclides, and nitrates. The Remedial Investigation/Baseline Risk Assessment was submitted 
for review by the regulatory agencies in May 1998 and the draft Rl/FS was submitted in September 1998. An interim action proposed plan will be issued in 1999 and the Record of Decision is expected in 2000.

\section{Waste Area Group 5 - Power Burst Facil- ity/Auxiliary Reactor Area}

Stationary Low-Power Reactor-1/Boiling Water Reactor Experiment-I. Although these two reactor burial sites are located in different Waste Area Groups, similarities led to combining them for the investigative and remedial processes.

The Stationary Low-Power Reactor-1 facility was a small nuclear power plant designed for the military to generate electric power and heat for remote installations. It accidentally achieved a critical reaction on January 3, 1961, resulting in a steam explosion that destroyed the reactor and killed the three operators on duty. To minimize radiation exposure to site workers and the public, a reactor burial ground was built for the contaminated debris near the original reactor site. Disposing of the material onsite was preferable to transporting the radioactive debris over $26 \mathrm{~km}$ (16 miles) of public highway to the Radioactive Waste Management Complex.

The Boiling Water Reactor Experiment-1 facility was a small reactor for testing boiling water reactor technology. It was intentionally destroyed in 1954 after completion of its mission. The destruction of the reactor contaminated about 2 acres ( 0.8 hectares) of surrounding terrain. Much of the reactor debris was buried in place, and the area was covered with about $15 \mathrm{~cm}$ (6 in) of gravel to reduce radioactivity levels.

Capping of these sites was completed in 1996. The Remedial Action Report was completed in September 1997. The caps receive routine inspection, maintenance, and periodic radiological surveys.
Auxiliary Reactor Area Removal Actions. In 1996 contaminated sludge was removed from aging septic tanks and placed in waste drums. The drums are currently kept in monitored compliant storage and will be shipped to the DOE Oak Ridge site for incineration in 1999. In 1998 , asbestos waste was removed from an area near the disposal pond.

Waste Area Group 5 Comprehensive RI/FS. This investigation began in February 1995. Waste Area Group 5 has 13 operable units and 54 potential release sites. Contaminants include heavy metals, radionuclides, and organic chemicals originating from such sources as underground tanks, hot cells, waste disposal ponds, a sewage system, and buried reactor debris. In 1998 the comprehensive investigation was completed. A Proposed Plan summarizing the investigation and Record of Decision will be issued in 1999. The comprehensive investigation identified seven sites that require cleanup: three waste disposal ponds, soils containing windblown radionuclides, soil beneath now-dismantled hot cells, a sanitary waste system, and an underground storage tank. The investigation proposed use of a soil separation technology, called the Segmented Gate System, to clean the contaminated soil. A treatability study using the Segmented Gate System will begin in June 1999.

\section{Waste Area Group 6 - Boiling Water Reac- tor Experiment}

Boiling Water Reactor Experiment-I. Remediation of this reactor burial site is included under Waste Area Group 5 with the Stationary Low-Power Reactor-1 discussion.

Waste Area Group 6 Comprehensive RI/FS. This comprehensive investigation is being conducted in combination with the Waste Area Group 10 comprehensive Rl/FS. 


\section{Waste Area Group 7 - Radioactive Waste Management Complex}

Remedial Action of Organic Contamination in the Vadose Zone. The Record of Decision to use the vapor vacuum extraction with treatment as the remediation technology for the vadose zone in the Subsurface Disposal Area at the Radioactive Waste Management Complex (RWMC) became final on December 2, 1994. The vadose zone is the area between the land surface and the top of the water table into which organic vapors were released when buried drums containing volatile organic compounds, such as degreasers and solvents, deteriorated over time.

The full-scale extraction/treatment system consists of three treatment units that extract vapors from three wells and break down the majority of organic compounds chemically to form carbon dioxide, hydrogen chloride, and water. The system began operations in January 1996 and as of 1998 , over 50,000 pounds of total volatile organic compounds have been removed from the vadose zone. The system will continue to extract and treat organics from the Subsurface Disposal Area in 1999.

Pit 9 Interim Action. In 1993, a Record of Decision (ROD) was signed for Pit 9 that identified an interim action consisting of limited retrieval and treatment of waste from the pit. A contractor, Lockheed Martin Advanced Environmental Systems (LMAES), was selected to perform the interim action. LMAES experienced problems in performing the interim action and DOE failed to meet two enforceable regulatory milestones, and in March 1997, the agencies developed an Agreement to Resolve Disputes [Reference 3-1].

As a result of the Agreement to Resolve Disputes, DOE developed a revised Remedial Design/Remedial Action Scope of Work and Remedial Design Work Plan [Reference 3-2]. The revised Work Plan included a new schedule for implementation of the Pit 9 ROD by the subcontractor and a schedule for a contingent path that would be implemented in the event the subcontractor failed to perform the subcontract. DOE, EPA, and the state of Idaho jointly developed this contingency plan. The agencies agreed to proceed with the contingency planning in order to ensure future schedules would be met. In addition, there was a need to obtain information to support the Waste Area Group 7 decision process, including characterization and treatability information.

On June 1, 1998, the INEEL M\&O contractor, LMITCO, terminated its Pit 9 subcontract with LMAES, citing failure to perform its obligations in a timely manner ("default"). In response to this action DOE notified EPA and the state of Idaho of its decision to pursue the jointly developed contingency plan, referred to as the Staged Interim Action.

The Staged Interim Action, a three-stage approach agreed to by the agencies, will satisfy the requirements of the ROD and has the same objectives as the original Pit 9 interim action:

- to remediate contamination to a level that protects human health and the environment;

- to provide information to support the final remedial decision for the Radioactive Waste Management Complex (RWMC) Subsurface Disposal Area (SDA); and

- to generate information to support the RI/FS for the RWMC SDA.

The Staged Interim Action consists of three stages. Stage I began in 1998 and will provide early information on specific subsurface conditions, including whether, how far, and which contaminants have migrated. This information is necessary to support the transport modeling and baseline risk assessment activities for Waste Area Group 7. Stage I will also include a limited treatment technology evaluation. Stage II activities include construction, soll treatment studies, and retrieval of bured material from an area of the pit selected durmg Stage I. During Stage II. further characterization and treatment information to support 
Waste Area Group 7 decisions will be obtained. Title I Design for Stage II commenced in late 1998 and will conclude in 1999. Stage III will complete the remediation of Pit 9 .

Waste Area Group 7 Comprehensive RI/FS. The Work Plan Addendum, detailing how the comprehensive investigation will be performed, was finalized in August 1998. The Addendum reflects schedule and scope changes that resulted from significant delays in the Pit 9 interim action, and describes additional scope to be completed. These changes will allow DOE to evaluate a wider range of remedial alternatives for the buried waste, including several treatability studies, in support of pit and trench remedial options.

\section{Waste Area Group 8 - Naval Reactors Facility}

Naval Reactors Facility Remediation. DOE, EPA, and the state of Idaho signed a Record of Decision for 10 sites at the Naval Reactors Facility (NRF) in 1994. Three of these sites were landfills that were capped with native soil covers in 1996. The agencies agreed the other sites (an industrial waste ditch and six other landfills) required no further action. During 1998, monitoring and maintenance continued at the landfills.

Waste Area Group 8 Comprehensive RI/FS. DOE, EPA, and the state of Idaho completed the comprehensive RI/FS for Waste Area Group 8 in September 1997. The RI/FS identified nine inactive waste sites with potential unacceptable risk to human health or the environment. The agencies recommended limited excavation, disposal, and containment as the preferred remedy for the nine sites of concern. The Proposed Plan was issued for public comment in January 1998. A Record of Decision for the comprehensive investigation of the Naval Reactors Facility was signed in September 1998. It addressed 64 remaining sites, including the nine inactive sites in the RI/FS. Cleanup work will begin in spring 1999.

\section{Waste Area Group 9 - Argonne National} Laboratory-West

Waste Area Group 9 Comprehensive RI/FS. In 1998, DOE, EPA, and the state of Idaho signed the comprehensive investigation Record of Decision on Argonne National Lab - West (ANL-W) which identified 5 sites requiring cleanup. The Record of Decision identified phytoremediaiton as the preferred method for removing contaminants from the soil at these five sites, except for portions of two sites. These two sites have additional contamination on which phytoremediation would not be effective and therefore approximately 76 cubic meters (100 cubic yards) of soil from these sites will be excavated and disposed of at an appropriate facility.

Phytoremediation is the use of selected plants to extract contaminants through their root systems. The plants are periodically harvested, dried, packaged, incinerated, and disposed of at an appropriate facility. The phytoremediation project will begin in 1999.

\section{Waste Area Group 10 - Miscellaneous Sites/Snake River Plain Aquifer}

Unexploded Ordnance Removal Actions. Prior to the inception of the INEEL in 1949, the U.S. Navy conducted aerial bombing practice, naval artillery testing, explosives storage bunker testing, and ordnance disposal at the Site. These activities resulted in the unexploded ordnance areas that are being addressed in the removal actions. Unexploded ordnance and explosive residues found to date include artillery shells, partially exploded bombs, anti-tank mines, anti-personnel mines, depth charges, smokeless powder, and dummy bombs with spotting charges.

Removal actions were performed from 1993 to 1998 . During these actions, unexploded ordnance and ordnance explosive wastes were removed from various sites at the INEEL. Removal of all ordnance contamination 
is planned to be completed to meet the objectives of DOE's 2006 Plan [Reference 3-3].

Radionuclide-Contaminated Soils Removal Action. On May 4, 1995, DOE, EPA, and the state of Idaho determined that seven of the Waste Area Group 10 sites with radionuclidecontaminated soil were to be remediated through removal actions. Excavation at one of the seven locations near TAN showed that contamination was widespread in several areas and could not be completely remediated through this soil removal action. Further assessment of that contamination is being conducted, and it may be appropriate to address this problem in the final TAN comprehensive RI/FS. The excavated areas were recontoured and reseeded.

Waste Area Group 10 Comprehensive RI/FS. The comprehensive investigation to address Waste Area Group 6 and 10 sites and the Snake Plain River Aquifer, as well as conducting the sitewide ecological risk assessment, will begin in early 1999, with the Record of Decision scheduled for completion in 2002.

\subsection{WASTE MANAGEMENT PROGRAM}

\section{Overview}

The mission of the Waste Management Program at the INEEL is to provide safe, compliant, and cost-effective management services for waste streams. Safe operations and compliance with federal, state, and local regulations are the highest priorities along with meeting the commitments made in the Idaho Settlement Agreement and the INEEL Site Treatment Plan. The goals of the program are to ensure that workers and the public are protected, and that the environment is not further impacted. INEEL waste management activities consist of:

- reducing the total amount of wastes generated;
- treating wastes already generated by reducing their toxicity, mobility, and volume;

- storing wastes awaiting development of new disposal and treatment options; and

- disposing of wastes.

Another challenge faced in managing wastes at the INEEL is involving the citizens of Idaho in the search for solutions to significant waste management issues. During 1998, the Waste Management Program made a number of presentations to the INEEL Citizens Advisory Board to explain issues related to the Program. Waste Management continues to promote openness with stakeholders in regards to these issues and works closely with the INEEL State Oversight Program and the congressional delegation. In addition, stakeholders participated in several tours of the INEEL that featured the mission and accomplishment of the Waste Management Program. A fact sheet, TRU News, was developed and distributed to key stakeholders. The fact sheet focuses on issues related to the INEEL Transuranic Waste Program.

Federal Facility Compliance Act. This act requires the preparation of site treatment plans for the cleanup of mixed wastes, those containing both radioactive and nonradioactive hazardous materials, at the INEEL. The INEEL Proposed Site Treatment Plan was submitted to the state of Idaho and EPA on March 31, 1995. Copies of the plan were also sent to various reading rooms throughout Idaho, the INEEL Citizens Advisory Board, and the Shoshone-Bannock Tribes. This plan outlined DOEID's proposed treatment strategy for INEEL mixed waste streams and provided a preliminary analysis of potential offsite mixed low-level waste treatment capabilities.

The final INEEL Site Treatment Plan formed the basis for negotiations between the state of Idaho and DOE on the consent order for mixed waste treatment at the INEEL. The Federal Facility Compliance Act Consent Order and Site Treatment Plan was finalized and signed by the 
state of Idaho on November 1, 1995. Two changes to the administrative sections of the Plan were negotiated to resolve issues between the State and DOE-ID: DOE reserved its right to challenge the approval authority of the State over offsite wastes and both parties agreed to immediately modify the Plan's schedules to be consistent with the Settlement Agreement and court order issued in October 1995 in the Spent Nuclear Fuel and INEEL Environmental Impact Statement litigation.

In accordance with the Site Treatment Plan, the INEEL began receiving offsite mixed waste for treatment in January 1996. The INEEL has received mixed waste shipments from other sites within the DOE complex including Hanford, Los Alamos, Paducah, Pantex, Sandia, and six locations managed by the Office of Naval Reactors.

Storage and treatment of the majority of the offsite waste will be performed at the Waste Reduction Operations Complex using incineration, macroencapsulation, stabilization, neutralization, and carbon absorption technologies. Additional offsite mixed wastes will be treated at the Advanced Mixed Waste Treatment Facility planned for construction at the INEEL in 2000.

Advanced Mixed Waste Treatment Project. The overall goal of the Advanced Mixed Waste Treatment Project (AMWTP) is the treatment of alpha low-level mixed and transuranic wastes for final disposal with a process that minimizes overall costs while ensuring safety. This will be accomplished through a private sector treatment facility with the capability to treat specified INEEL waste streams, and with flexibility to treat other INEEL and DOE regional and national waste streams. The services will treat waste to meet the most current requirements, reduce waste volume and life cycle cost to $\mathrm{DOE}$, and perform tasks in a safe, environmentally compliant manner.
A contract for treatment senvices was awarded to BNFL Inc. in December 1996. The contract was awarded in three phases.

- Phase 1 - licensing, permitting and environmental compliance: to be completed in April 2000.

- Phase $\mathrm{Il}$ - construction and process demonstration: to be completed in December 2002.

- Phase III - treatment operations: to begin by March 2003.

AMWTP completed several major milestones in 1998.

- Draft RCRA/TSCA Permit Applications were submitted to EPA and state of Idaho on January 16, 1998 and declared administratively complete.

- Draft Air Permit to Construct and NESHAP Applications were submitted on April 18, 1998 and declared administratively complete.

- Environmental Impact Statement was issued July 14, 1998.

- BNFL Environment, Safety, and Health Program Operating Plan was approved by DOEID on July 16, 1998.

- Quality Assurance Project Plan and Radiation Protection Plan was approved December 1998.

The facility will operate until 2015 with the possibility of continued operations until 2033.

High-Level Waste Treatment and Facilities Disposition. High-level waste (HLW) is a product of reprocessing spent nuclear fuel and is highly radioactive. HLW includes liquid waste produced directly from reprocessing and any solid waste (calcine) derived from the liquid. At the INEEL, HLW exists in both liquid and solid forms and is stored in underground tanks and in bins at INTEC. The INEEL completed calcining of all liquid non-sodium bearing HLW on February 20,1998, four months ahead of the June 30, 1998 Idaho Settlement Agreement 
milestone. Calcining of sodium-bearing liquid waste began on February 20,1998, more than three years ahead of the Settlement Agreement milestone. All of this waste is required to be calcined by the end of the year 2012 . The waste and the amount to be treated are characterized in the Spent Nuclear Fuel and INEL Environmental Impact Statement.

Low-Level Radioactive Waste. The M\&O contractor and DOE-ID have established a goal to dispose of the backlog of stored low-level radioactive waste (LLW) onsite by September 30, 1999. Disposal activities at the Radioactive Waste Management Complex Subsurface Disposal Area (SDA) in 1997 and 1998 reduced the LLW backlog by over 7,000 cubic meters.

The goals for fiscal year 1999 include disposal of up to 6,500 cubic meters $(8,450$ cubic yards) of stored and newly generated LLW at the SDA; compaction of 5,438 cubic meters (7,069 cubic yards) of LLW at the Waste Experimental Reduction Facility (WERF); and sizing of 340 cubic meters (442 cubic yards) of LLW at WERF. Additional plans being evaluated by DOE and stakeholders call for using the SDA for onsite disposal of contact-handled LLW through 2006 and remote-handled LLW through 2008.

Waste Minimization/Pollution Prevention. The mission of the INEEL Pollution Prevention Program is to reduce the generation and release of wastes and pollutants by implementing cost-effective pollution prevention techniques, practices, and policies. Pollution prevention is also required by various federal edicts, including but not limited to, the Pollution Prevention Act, the Resource Conservation and Recovery Act, Executive Order 12856 (Federal Compliance with Right-To-Know Laws and Pollution Prevention Requirements), and Executive Order 12873 (Federal Acquisition, Recycling, and Waste Prevention).

It is the policy of the INEEL to incorporate pollution prevention into every activity. Pollution prevention is one of the key underpinnings of the INEEL Environmental Management System [see Section 3.1]. It functions as an important preventive mechanism in that reduced waste generation reduces waste management costs, compliance vulnerabilities, and the potential for environmental insult. The INEEL is promoting the inclusion of pollution prevention into all planning activities as well as the concept that pollution prevention is integral to mission accomplishment.

Noteworthy pollution prevention accomplishments in 1998 include:

- 19.2 metric tons of expired chemicals were not disposed of as hazardous waste due to improved chemical management practices and increased participation in the Material Exchange Program at the INEEL.

- Implementation of electronic documentation of policies and procedures and a new electronic mail system that allows for electronic document review and storage of information, facilitating a reduction in the amount of sanitary waste generated by 1,957 metric tons.

- RCRA materials (including lead scrap, lead acid batteries, RCRA scrap, and silver scrap) were recycled, reducing hazardous waste by 83 metric tons and saving $\$ 1,656,800$.

- Sanitary waste generation was decreased by 4,271 metric tons as a result of recycling/reuse, fewer INEEL facility cleanups, and reduced decommissioning and decontamination operations.

Recycle and Reuse Activities. INEEL vigorously pursues opportunities for reuse and recycle of eligible waste materials for energy recovery and to maximize available landfill capacity. In 1997, the INEEL received a grant the DOE Office of Pollution Prevention to build a facility, called the cuber system, to convert waste material, such as office trash, unclassified sensitive documents, and wood chips, into a process engineered fuel. The fuel "cubes" are burned in the INTEC Coal Fired Steam Genera- 
tion Facility (CFSGF), which produces process and heating steam for the facility. The cubes supplement coal used at the facility, thereby reducing the amount of coal burned and achieving a cleaner and more efficient combustion than coal alone. Burning cubes has reduced sulfur and nitrogen oxide emissions and heavy metal releases. Since starting operations in November 1996, the cuber has processed 33.7 metric tons of nonradioactive solid waste from INTEC and other INEEL facilities. Seventy-six percent of the waste previously destined for the landfill can be processed in the cuber, translating to potential savings of $\$ 1.1$ million in annual operating costs for the CFSGF.

Below are other examples of INEEL energy recovery projects in 1998:

- The Mobile Test Assembly Cask was dismantled, with clean lead sent to the clean lead storage area for recycling. This recycle/reuse activity reduced clean up/stabilization hazardous waste by approximately 20 metric tons, for reported cost savings of $\$ 408,600$.

- The Specific Manufacturing Capability facility recycled depleted uranium scrap metal material from normal facility operations, and depleted uranium scrap metal during deactivation of a facility. These recycle/ reuse activities reduced both routine operations and cleanup/stabilization low-level radioactive waste by approximately 19 cubic meters, for reported cost savings of $\$ 23,400$.

- INEEL engine oil was recycled by a commercial recycler for reuse at a cement plant. This recycle/reuse activity reduced routine operations hazardous waste by approximately 55 metric tons, for reported cost savings of $\$ 1,106,800$.

Lead Management Program. The intent of the INEEL Lead Management Program is to:

- minimize new lead purchases,

- evaluate lead substitutes,
- maximize reuse of contaminated lead for shielding,

- protect lead from contamination,

- reduce the accumulation of contaminated lead,

- recycle contaminated lead to the scrap metal market (by decontamination and surface and volumetric survey prior to release of the material), and

- provide the means for generators to dispose of mixed waste lead.

The INEEL Site Treatment Plan backlog schedule for treatment of mixed waste leadshielded casks was established in January 1996. The backlog schedule identified 132.6 cubic meters ( 179 cubic yards) of waste lead and lead-shielded casks. To date, 81.15 cubic meters ( 106.78 cubic yards) of waste have been processed through the cask dismantlement activity: 9.27 cubic meters ( 12.05 cubic yards) in 1996, 61 cubic meters (80 cubic yards) in 1997, and 10.88 cubic meters (14.14 cubic yards) in 1998. More than 50 percent of the backlog was processed as of September 1998. Therefore, the established schedule to process 25 percent of the backlog by March 31,1998 , and to process $50 \%$ by March 31, 1999, were both completed ahead of schedule. By September 1999, 75 percent of the backlog is expected to be processed.

Alternative-Fuel Vehicle Program. The INEEL has embarked on a program to phase natural gas vehicles into its vehicle fleet over the next several years under the alternative-fuel vehicle program (AFV). Currently the INEEL fleet consists of approximately 107 over-theroad motor coach buses and 712 light duty vehicles (cars, vans, and pickup trucks). The fleet presently uses 1.1 million gallons of diesel, gasoline, liquefied natural gas (LNG), compressed natural gas (CNG), and propane each year. It is projected by 2005,80 percent of INEEL's fleet will use natural gas. The first goal set to accomplish this objective was achieved by converting seven buses and 126 
light duty vehicles to natural gas by 2000 . The seven LNG-powered buses have performed well. This cooperative effort between the INEEL and industry has been highly successful in proving the technology both from operational and emissions performance standpoints. Operational testing has proven the LNG engine's ability to compete with existing fossil engines, and at the present the 1,450-plus-km (900-mile) range of two of the buses is a competitive advantage.

Following INEEL's tradition of providing technical support to advance AFV technology and use, INEEL continued its outreach efforts. INEEL researchers and Fleet Operations personnel consulted with New Mexico and Texas transit fleet operators on AFV problems. The INEEL shared its experience addressing the types of problems that the transit fleets are having using natural gas as an alternate fuel for vehicles. The INEEL is recognized by industry as having a wealth of experience in using natural gas vehicles. This activity aided in removing barriers facing the transit industry enabling alternate fuels to be more fully utilized while decreasing use and dependence on petroleum.

In other community support projects, INEEL Fleet Operations provided environmental awareness training to the City of Idaho Falls Vehicle Maintenance Shop at its request. Fleet Operations worked with the INEEL Institute and Idaho Division of Vocational Education to explore opportunities for training instructors from the post-secondary schools around the state, focusing on automotive shop technologies and AFVs. The first training session was held in July for a Rigby High School instructor and four of his students. In 1998, INEEL Fleet Operations entered into an agreement with Westport Innovations to test and demonstrate their High Pressure Direct Injector technology using Fleet Operations' dynamometer. The project was performed under a work for others agreement.

INEEL Fleet Operations continue to meet the regulations of the Clean Air Act and Executive Orders, specifically in fossil fuel emissions reduction requirements and AFV acquisition goals. In addition to excellent emissions performance, maintenance requirements for natural gas-powered vehicles have been observed to be lower than those of conventional vehicles. The buses have accumulated approximately $480,000 \mathrm{~km}$ (300,000 miles) without any mechanical failures related to natural gas. The INEEL is performing research and development on a low-cost liquefaction fueling station to help overcome the scarcity of refueling stations. The INEEL recently entered into a $\$ 4.7 \mathrm{M}$ Cooperative Research and Development Agreement with two private companies to further this research.

Offsite Mixed Low-Level Waste Treatment. The INEEL is marketing the capacity to treat DOE mixed low-level waste by incineration at the Waste Experimental Reduction Facility (WERF). Under provisions proposed in the INEEL Site Treatment Plan, any offsite waste received at the INEEL must be treated within six months of receipt, and all treatment residues must be sent out of Idaho within six months of treatment.

Since the first offsite waste treatment campaign in 1996, shipments of mixed low-level waste have been received and incinerated from the Naval Nuclear Propulsion Program (Mare Island, Charleston, Puget Sound, Pearl Harbor, and Norfolk Naval Shipyards), Bettis and Knolls Atomic Power Laboratories, and other DOE sites (Los Alamos, Hanford, Pantex, Sandia and Paducah).

WERF Waste Processes Program. WERF processed mixed low-level waste/low-level waste (MLLW/LLW) throughout 1998. The WERF incinerator processed 205.5 cubic meters (267.15 cubic yards) of MLLW and 653.04 cubic meters ( 848.95 cubic yards) of LLW. In addition to the incineration of MLLW/LLW, LLW volume reduction was performed: 2,131.15 cubic meters (2770.5 cubic yards) of LLW was compacted and 906.17 cubic meters $(1,178.02$ cubic yards) was sized; 
866 shifts of waste processing were performed in 1998.

Dry Fuel Storage Agreement. A major Idaho Settlement Agreement milestone was completed on December 23, 1998, when DOE completed construction of the Three Mile Island dry storage facility. This milestone is tied to the milestone to commence moving fuel into the facility by March 31, 1999.

Based upon concerns expressed by the state of Idaho about seismic vulnerabilities of the Irradiated Fuel Storage Facility (IFSF), additional seismic analysis was performed in 1997 in preparation for proposed modifications to the facility west wall. The analysis demonstrated that the facility seismic deficiencies could be eliminated. Modifications to the facility west wall were completed in December 1997. On January 7,1998 , the State agreed that the facility was adequate for storage of the CPP603 basin fuels and provided its authorization for such storage. DOE-ID began transfer of CPP-603 fuels on February 5, 1998. At the time approval was given to resume transfers from the CPP-603 basin to IFSF, 455 fuel positions remained to be transferred in order to meet a U.S. District Court Order to remove all fuel by December 31, 2000. In 1998, 225 fuel storage positions were emptied in CPP-603 into the IFSF.

\section{Idaho Settlement Agreement}

On October 16, 1995, DOE, the United States Navy, and the state of Idaho entered into an agreement which will guide management of spent nuclear fuel and radioactive waste at the INEEL for the next 40 years. The agreement makes Idaho the only state with a federal court-ordered agreement limiting shipments of DOE and Naval spent nuclear fuel into the state and setting milestones for shipments of spent nuclear fuel and radioactive waste out of the state.

During 1997, DOE lowered the risk of potential releases to the Snake River Plain Aquifer by reducing the total volume of liquid high-level waste stored in underground tanks at the INEEL. Operation of the High-Level Liquid Waste Evaporator in early 1997 reduced liquid waste inventory by over $1,249,000$ liters (330,000 gallons). In June 1997, DOE began converting the concentrated liquid waste into a granular, more stable form called calcine with the restart of the New Waste Calcining Facility after a three-year shutdown.

In 1998, DOE accomplished two high-level waste milestones ahead of schedule. On February 20,1998 , DOE completed calcining the remaining inventory of liquid non-sodium bearing high-level waste four months ahead of the June 30, 1998 due date. Also on February 20, 1998, DOE commenced calcining liquid sodium bearing high-level waste more than three years ahead of the June 1, 2001 due date.

DOE and BNFL, Inc. met state licensing requirements for siting a new hazardous mixed waste treatment facility on the INEEL. This was the first of several steps for the Advanced Mixed Waste Treatment Project, a facility for treating clothing, equipment, tools, and sludge contaminated with hazardous chemicals and radionuclides such as plutonium. The facility will destroy the hazardous constituents, reduce the volume, and prepare the waste for disposal at the Waste Isolation Pilot Plant in New Mexico. This facility is currently slated to incinerate and vitrify 22 percent of waste and supercompact and/or macroencapsulate the remainder of the waste. The facility will also be designed to meet the technical requirements of Idaho's Hazardous Waste Management Act and the Clean Air Act.

Because of poor conditions in aging facilities, DOE is aggressively moving spent nuclear fuel into safer interim storage at the INEEL. DOE applied for a license with the Nuclear Regulatory Commission for a new dry, aboveground storage facility to house the damaged Three Mile Island reactor core and spent fuel, currently stored in a deteriorating water basin. DOE is also continuing to transfer other spent 
fuel from aging basins into more modern facilities.

As an alternative to wet storage of its spent nuclear fuel, the Navy is designing and manufacturing containers for dry storage and eventual transport out of Idaho. The Navy also began design and contractual preparations for the facility to load fuel into these containers.

As part of the Settlement Agreement, the state of Idaho received its third installment of $\$ 6$ million from DOE for economic development in eastern Idaho. Idaho awarded grants to the Regional Development Alliance and state universities and colleges to reduce economic dependence on the INEEL. Awards to date have created over 2,000 jobs. In northern Idaho, the Navy met a settlement agreement commitment by beginning a $\$ 7$ million expansion project at its Acoustic Research Detachment on Lake Pend Oreille.

Transuranic Waste. The Transuranic (TRU) Waste Program accomplished several major goals in 1998. Waste Isolation Pilot Plant (WIPP) Certification Authorization was received from the DOE Carlsbad Area Office on April 29, 1998, moving INEEL one step closer to shipping waste to WIPP. An inspection for EPA certification was also completed in July 1998. The TRU Waste Characterization Program will ensure TRU waste is properly characterized to meet the WIPP waste acceptance criteria. Efforts to characterize and certify TRU waste for disposal directly support meeting the Idaho Settlement Agreement milestone to remove 15,000 drums of TRU waste from Idaho by December 31, 1002. The Stored Waste Examination Pilot Plan (SWEPP) has non-destructively examined 2,504 drums of TRU waste to provide sufficient inventory of certified TRU waste to support shipments out of Idaho. An automated information management system known as the Transuranic Reporting Inventory and Processing System (TRIPS) is under development to support collection of waste characterization data, review and validate data, and report to WIPP. TRIPS incorporates the use of electronic signatures on database entities which ensures data integrity, user authenticity, and non-repudiation for data and signatures on specific database entities. This technology will result in a cost savings of over $\$ 7.65$ million through the year 2002 .

Efforts in support of the Matrix Depletion Program continued to provide scientific evidence to support the reduction of WIPP Waste Acceptance Criteria transportation requirements. The INEEL continued to assist in the execution of the Performance Demonstration Program, which certifies that equipment across the complex is operating satisfactorily and provides assurances to the regulators of WIPP that waste is being properly characterized.

The TRU project continued to support efforts to examine the effectiveness of nondestructive assay technologies by testing four systems at the RWMC in 1998. This is a joint venture between the DOE-ID TRU Program and the Mixed Waste Focus Area. The Focus Area will use the results of the demonstration to determine additional technology improvements for waste assay.

\section{Waste-related Research and Development}

A wide variety of research projects are conducted at the INEEL to benefit major DOE-ID programs. The Environmental Science and Research Foundation and its university affiliates primarily conduct ecological and radioecological research. The M\&O contractor conducts a wide range of projects including methods of waste characterization and disposal, robotics, alternative-fuel vehicles, and bioremediation of wastes.

Environmental Science and Research Foundation. The Environmental Science and Research Foundation, an independent nonprofit organization, conducts a variety of wasterelated research for DOE-ID on the INEEL. Much of this work is performed through a network of university affiliates from local and regional academic institutions working with the Foundation. 
The Protective Cap/Biobarrier Experiment (PC/BE) was designed to rigorously test the performance of four protective cap configurations for low-level buried wastes in semi-arid to arid climates. The ultimate objective of the experiment is to confidently recommend an effective, economical soil-plant cover system for interred wastes at the INEEL and climatically similar repositories.

In order to effectively store wastes underground, water must be kept out of the waste material. During the first three years, baseline data were collected on plant establishment, rooting depths, patterns of soil water storage and depletion. Burrowing ants were then introduced to the plots in 1996, and burrowing rodents were introduced in the spring of 1998. Current plans call for application of excess irrigation until cap failure occurs (drainage through the entire cap) in 1999. Results from these manipulations will allow the prediction of the amount and seasonal distribution of precipitation that could fall on the site before a particular cap configuration would fail, and whether burrowing organisms will significantly affect cap performance under high levels of precipitation.

The intrusion of burrowing mammals into hazardous waste areas and the subsequent transport of waste off the burial area has been shown to be a problem in older waste areas and continues to be a concern regarding future closure of current waste areas. The objective of one study is to determine the effectiveness of three types of material in preventing the burrowing of small mammals into waste areas. The three materials are $5-$ to $10-\mathrm{cm}$ (1- to 2in) cobble, chipped roofing gravel, and a mixture of gravel and cobble. Townsend's ground squirrels and Ord's kangaroo rats were introduced into test enclosures containing $50-\mathrm{cm}$ (20-in) thick layers of these materials overlain by native soil. In 1998 , burrows within the enclosure were excavated to determine their depth of penetration. No penetration of the biobarrier material by ground squirrels or kangaroo rats was found. An additional objective was to determine whether creating such a biobarrier in the presence of burrowing mammals might alter soil moisture patterns and compromise the integrity of the waste cap. Soil moisture above and below the biobarriers during spring recharge was determined. The presence of small mammals did not affect soil moisture. However, soil moisture was higher above the biobarriers and, when it did penetrate the biobarrier, water was able to penetrate deeper into the profile than was found to be the case in the enclosures without the biobarriers.

Part of the $\mathrm{PC} / \mathrm{BE}$ research is to determine the effectiveness of preventing harvester ants from burrowing through biobarriers and to determine the effect of ant nests on water infiltration of the soil. Ant nests were established on the PC/BE at about the average natural densities for the surrounding area. The Foundation found that ant nests increase water infiltration rates by at least 10 -fold, and much more in some cases.

Another potential problem in managing soil water in a protective cap at the INEEL is invasion by exotic annual plants, such as cheatgrass and Russian thistle. Annual species are more ephemeral than native perennials, and their abundances may fluctuate widely with year-to-year variations in weather. To be confident about the long-term performance of an evapotranspiration cap, we must understand how the caps will perform with annual plants. In 1998, the Foundation conducted a greenhouse experiment to compare soil-water extraction of cheatgrass and Russian thistle with that of crested wheatgrass. Soil-water content on field plots planted with perennial species or cheat grass was also monitored. Results to date confirm $2 \mathrm{~m}$ of soil supporting a healthy stand of perennial plants is more than adequate to store precipitation that falls at the INEEL and to return that moisture to the atmosphere each growing season, thereby precluding drainage. Preliminary results suggest some annuals (e.g., Russian thistle) do not use all the plant-available water, consequently 
reducing the soil water storage capacity for the subsequent non-growing season. Lithium tracer experiments suggest gray rabbitbrush and crested wheatgrass may be primarily responsible for water extraction from beneath biobarriers.

Various EPA and DOE regulations require shallow-land burial sites for mixed low-level radioactive wastes remain effective at least 100 years. Primary to the success of a waste management site is the capability to keep wastes isolated from water. At the INEEL, most of the annual soil moisture recharge results from precipitation during the months when plants are dormant (October - March). Improvements in management practices since 1952 at the RWMC have resulted in differences in soil covers, thickness, land contours, vegetation types, and proximity of buried wastes to roads and ditches. Each of these factors influences soil moisture dynamics in the protective soil caps.

Since 1988, the Foundation has measured soil moisture on eight study sites within the RWMC, mostly during the late winter, early summer, and fall to compare soil moisture dynamics in areas with different management histories. Throughout that period, precipitation during the non-growing season ranged from $46.6 \%$ to $135.5 \%$ of normal. Soil moisture recharge was generally less than $40 \mathrm{~cm}$ (16 in) deep for all areas and years except for 1989 , 1993, 1995, 1997, and 1998. During those years maximum infiltration was recorded at depths of up to $1.4 \mathrm{~m}(4.6 \mathrm{ft})$.

The transport of contaminants from buried waste sites via plant uptake and animal burrowing must also be understood in order to ensure waste isolation. The Foundation is conducting research to quantify contaminant uptake by vegetation and burrowing organisms on decommissioned radioactive waste ponds at the TRA on the INEEL. The three liquid radioactive waste leaching ponds, constructed in 1952,1957 , and 1964, received an estimated $53.5 \mathrm{kCi}$ of activity between 1952 and 1993.
All ponds were taken out of service in 1993 , and two were closed in late 1993 and early 1994 with a simple soil cover containing no biobarriers to inhibit root infiltration or burrow penetration. Vegetation species and biomass were determined for those two pond covers and samples of vegetation were analyzed for gamma-emitting radionuclides, ${ }^{90} \mathrm{Sr},{ }^{238} \mathrm{Pu}$, ${ }^{239 / 240} \mathrm{Pu},{ }^{241} \mathrm{Am}$, and selected trace metals. The covers were also surveyed for burrowing activity. A total of 46 burrow sites were located on the 1964 pond cover and a total of 15 burrow sites were located on the 1952 pond cover. Average concentrations in vegetation and in small mammal- and ant-excavated soils were elevated compared to control samples. The uptake of radionuclides by vegetation and burrowing activity was occurring across both the covers. During 1999 engineered covers incorporating human intrusion barriers will be put in place over the old covers. The Foundation will continue work to quantify contaminant uptake by vegetation and burrowing organisms on the decommissioned radioactive waste ponds. The specific objectives of this research are to determine if vegetation uptake of radionuclides is occurring on the new covers, to determine if burrowing animals are transporting radionuclides to the surface of the new covers, to determine the extent and magnitude of radionuclide uptake in relation to the simple soil covers, and to predict future exposure rates and surface contamination levels based on measured uptake and redistribution of radionuclides.

Following the construction of two hypalonlined evaporation ponds at TRA and the closure of the percolation ponds formerly used for disposal of wastes at this facility, the Foundation initiated a study in 1994 to obtain current data on potential doses from game animals using the ponds. During 1998, 12 waterfowl and nine mourning doves were collected from radioactive waste disposal ponds at TRA and INTEC and a sewage pond at Argonne National Laboratory-West (ANL-W). Control samples were also collected from Snake River on the 
Fort Hall Indian Reservation, about 70 kilometers (45 miles) southeast of TRA and INTEC. Radionuclide concentrations in the edible portion of the ducks were used to estimate the potential dose to an individual consuming waterfowl from each facility. Results from the analysis of waterfowl and doves are reported in Chapter 4; estimated potential doses to humans from consumption of the birds are presented in Chapter 8.

Summaries of these and other Foundation research projects are published annually [Reference 2.4].

\subsection{ENVIRONMENTAL RISK REDUCTION}

\section{Decontamination and Dismantlement (D\&D)/Demolition Activities}

$D \& D$ and demolition activities at the INEEL are primarily concerned with the safe and compliant decontamination and disposition of inactive facilities and structures potentially suitable for reuse, and the D\&D/demolition and disposal of inactive facilities and structures not suitable for reuse. Ten facilities and structures were identified for D\&D in FY 1998.

Pollution Prevention. INEEL D\&D projects are required to apply the precepts of pollution prevention and waste minimization. Such applications are accomplished by onsite incineration, compaction, and sizing technologies at the INEEL Waste Experimental Reduction Facility prior to their disposal at the INEEL Radioactive Waste Management Complex. The reuse and reclamation of equipment and materials resulting from $D \& D$ activities is a major goal of D\&D projects. In 1998, D\&D project activities recycled/reused structural steels, component items, and brass/bronze totaling approximately 265 tons, 15 tons, and 3 tons, respectively.

Test Reactor Area. The INEEL Large Scale Demonstration and Deployment Project conducted a demonstration in the TRA-660 canal in August 1998. The demonstration involved a remotely operated underwater vehicle with video capability and Geiger-Müller tube radiation detection to obtain real-time information. The TRA-660 canal fuel rack was removed, packaged, and transported, along with lead and cadmium from TRA-660, to the WERF Waste Storage Building in September 1998.

Auxiliary Reactor Area. Work on Auxiliary Reactor Area (ARA)-I and -III continued in 1998. Structural demolition and removal of the ARA-626 Hot Cell at ARA-I was completed in January 1998. Three leaded glass windows of the Hot Cell were removed, packaged, and shipped offsite for reuse. D\&D of the last three buildings at ARA-III began in February 1998, followed by dismantlement in order to excess the reusable structures.

Central Facilities Area. D\&D of the old Sewage Treatment Plant was initiated in 1998 as part of the ongoing cleanup activities. The radioactively contaminated clarifier, trickler filter, and filter media were removed and disposed of at the Central Facilities Area landfill. Approximately 63,560 kilograms $(140,000$ pounds) of contaminated soil were removed from the Sludge Drying Beds. The soil was packaged and staged in the Radioactive Material Area at the Sewage Plant and is planned for disposal as low-level radioactive waste.

Idaho Nuclear Technologies and Engineering Center. The first phase of a three-phase innovative closure project for the Waste Calcining Facility (WCF) was completed in 1998. The first phase involved filling three basement levels of the facility, including rooms, hallways, pipes, and vessels, with more than 3,192 cubic meters $(4,200$ cubic yards) of grout. The grout created an underground monolith that encapsulates and prevents migration of any contaminants. Phases II and III, involving demolition of above-surface structures and capping the site with concrete, will be completed in 1999. Extensive D\&D was performed on the Service Waste Monitoring Station (CPP709) in 1998. Piping, pump bases, pump 
extensions, steel plating, and water were removed and disposed of.

Test Area North. D\&D was performed on the Initial Engine Test area. Interior asbestos abatement was completed and dirt overburden, carbon steel plate, and structural iron above the generator room were removed to aid in removing large equipment from the area. Buildings near the Test Area North that were associated with the former Aircraft Nuclear Propulsion Program were also removed in 1998.

Radioactive Waste Management Complex. The Certification and Segregation Building, also known as the Air Support Building, was removed in 1998. The Building formerly stored drums of transuranic waste that were destined for WIPP. The drums are now stored in regulatory-compliant storage buildings at the Radioactive Waste Management Complex. Future plans for the area involve construction of the Advanced Mixed Waste Treatment Facility.

\subsection{NATIONAL PROGRAMS MANAGED AT DOE-ID}

National Analytical Management Program. The National Analytical Management Program (NAMP) is managed through DOE-ID. Its mission is to promote quality in the planning, management, and performance of sampling and analysis activities which generate characterization and monitoring data in support of DOE environmental quality initiatives. The NAMP provides national leadership to the DOE Office of Environmental Management (EM) through:

- establishing national policy,

- developing complex-wide technical guidance,

- serving as a national clearinghouse for resolution of EM analytical services issues, and
- providing forums for collection, discussion, and dissemination of information on DOE analytical services.

NAMP is the focal point for technical and managerial excellence in EM analytical services. It ensures that EM receives quality analytical data through traceability to the National Institutes of Standards, accreditation and audit consolidation, and performance evaluation programs. NAMP projects cover diverse areas and are directly responsive to EM customer requirements. The core NAMP project areas are program and resource management, information systems, data handling, accreditation, quality assurance and control, technical development, and interagency cooperation.

An exemplary NAMP project, the Mixed Analyte Performance Evaluation Program (MAPEP), is a major laboratory performanceevaluation program implemented through the Radiological and Environmental Sciences Laboratory. MAPEP distributes samples containing known quantities of specific analytes to participating laboratories for analyses. This year, participation grew to approximately 100 laboratories, over 25 percent of which are foreign.

Plutonium Focus Area. In May 1994, the Defense Nuclear Facilities Safety Board issued Recommendation 94-1 expressing concern that the halt in weapons production froze the manufacturing pipeline, leaving it in a state that "...for safety reasons, should not be allowed to persist unremediated. [Reference 3-4]" In the recommendation, the Board expressed concern about certain liquids and solids containing unstable fissile materials and other radioactive substances stating "...imminent hazards could arise within two to three years unless certain problems are corrected." In response to Board concerns, the Plutonium Focus Area (PFA) was chartered in October 1995 to implement the 94-1 Research and Development Plan identifying, developing, and deploying technologies for the stabilization, characterization, packaging, transportation, and interim storage of plutonium residues. 
PFA is a multi-year (i.e., 1995-2002), complex-wide program that includes collaboration on technology ventures with Russian scientists as part of the U.S.-Russian nonproliferation program. PFA research and development projects for 1998 include:

- demonstrating integrated plutonium monitoring and surveillance system,

- developing a chemical bonded phosphate ceramic process,

- advanced technologies for stabilization of plutonium-238,

- developing a modular arm for automated plutonium gloveboxes,

- collaborating on Russian stabilization technologies for problematic actinide solutions, and

- continuating complex-wide integration functions.

Mixed Waste Focus Area. DOE-HQ established an integrated approach for addressing waste issues based on focus or problem areas. The INEEL was selected as the lead laboratory for mixed waste technology development. Managed by DOE-ID, the Mixed Waste Focus Area (MWFA) operates in close partnership with end users and regulators to address and meet priority needs and ensure that demonstrated solutions are accepted and approved for deployment. DOE identified more than 2,300 mixed waste streams at its sites, including stored inventory and waste generated by ongoing processes and cleanup activities.

In 1998, emphasis shifted from demonstrations of large-scale thermal treatment to development and demonstration of ancillary and enabling technologies. Needs identified by DOE sites were analyzed and successful technologies and solutions were developed and deployed.

Several new stabilization technologies were developed by DOE laboratories and demonstrated for application on a variety of DOE salt-, ash- and soil-type wastes. Two such technolo- gies, Chemically Bonded Phosphate Ceramics and Polymer Microencapsulation, are now commercially available. MWFA applied scientific expertise to solve problems associated with the shipment of transuranic waste, which included expansion of the TRUPACT-II payload. New work was started at the DOE Savannah River Site and the INEEL on mechanical systems for handling and removing materials from high activity waste containers. The Expert System for nondestructive assay validation was developed and installed at the INEEL. Two amalgamation demonstrations with elemental mercurybearing waste and three stabilization demonstrations were completed with commercially available technologies.

National Low-Level Waste Management Program. The National Low-Level Waste Management Program (NLLWMP) at INEEL assists DOE in fulfilling its responsibilities under the Low-Level Radioactive Waste Policy Amendments Act of 1985.

The objective of the NLLWMP is to provide technical expertise, information, and other resources to states and compact regions in support of the development of their LLW management facilities. The NLLWMP maintains contact with state and compact region officials to identify and provide general and specific assistance. Principal areas of activity include providing workshops, fulfilling state-specific requests, developing technical documents, distributing general information on LLW, providing information management, providing technical coordination of organizations and LLW management projects, and supplying other assistance.

In 1998, the NLLWMP completed 13 workshops, including a state-requested workshop on risk communication and public decision-making. The workshops provided visibility to the INEEL as the low-level waste center of excellence.

National Spent Nuclear Fuel Program. The DOE Idaho Operations Office manages the 
National Spent Nuclear Fuel Program (NSNF). Its mission is to safely and efficiently manage DOE-owned spent nuclear fuel (SNF) and prepare it for disposal. In completing this mission, the DOE Environmental Restoration and Waste Management Programs, while working with stakeholders, will protect the environment and the health and safety of workers and the public while fully complying with applicable federal, state, tribal, and local laws, orders, and regulations. The scope of the NSNF to which these requirements applies is defined by what constitutes DOE-owned SNF as well as the DOE programs and facilities needed to satisfactorily complete the mission.

DOE will manage material as spent nuclear fuel if it is irradiated fuel or targets containing uranium, plutonium, or thorium, that are permanently withdrawn from nuclear reactors or other neutron irradiation facilities following irradiation, the constituent elements of which have not been separated by reprocessing. Such materials include essentially intact fuel, disassembled or damaged units and pieces, and other materials.

A large number of different SNF types are stored within the DOE complex. Of the different types, several categories of DOE-owned SNF may be defined. DOE facilities that come under the NSNF program include those conditioning and storage facilities within which DOE-owned SNF currently resides and new facilities that are brought on-line to effect the mission of providing safe, interim storage.

National Transportation Program. The National Transportation Program (NTP) serves as the corporate center of packaging and transportation expertise within the DOE Office of Environmental Management. It supports infrastructure and coordinates transportation activities for all non-classified shipments of hazardous materials, including radioactive and mixed wastes, and other commodities such as coal, other fuels, maintenance materials, and supplies.
The NTP is responsible for ensuring the availability of safe, secure, and economical transport services; consistency in regulatory implementation; coordinated outreach; and emergency preparedness assistance for DOE. A corporate team composed of personnel from the DOE Headquarters, Idaho, and Albuquerque offices manages the NTP.

\subsection{ADDITIONAL ENVIRONMENTAL PROGRAMS}

Public Involvement Activities. INEEL public involvement activities during 1998 included:

- publishing three INEEL Reporters,

- publishing two INEEL Reporter Progress Report Supplements,

- publishing two Inside INEEL inserts, including distribution via newspapers to 350,000 households each,

- holding two citizen focus group meetings via satellite teleconference concerningWAG 1 and WAG 3 proposed cleanup plans,

- hosting three major public scoping meetings for environmental impact statements,

- providing more than a dozen briefings to the INEEL Citizens Advisory Board,

- holding seven briefings with the ShoshoneBannock Tribes,

- hosting 148 tours with a combined attendance of 2,161 people, and

- holding ten public meetings and two rounds of media briefings on WAGs $1,3,8$ and 9 .

Members of the public may call $1-800-$ $708-2680$ to request specific documents. These documents are also available on the Internet at http://www.inel.gov under "About INEEL."

Public Communication and Education Activities. To foster public understanding of environmental issues involving the INEEL, concerted 
communication and education efforts are made by DOE-ID and its contractors. A wide array of tours, speaking engagements, newspaper inserts, newsletters, displays, and opportunities to request INEEL information are made available to interested persons. These efforts provided information directly to about 400,000 people in 1998. News releases and other contacts with journalists spread INEEL messages to much wider audiences.

Through a toll-free telephone number (800708-2680), anyone can call the INEEL to ask questions and request copies of documents.

M\&O Contractor Public Affairs. Because the M\&O contractor Public Affairs Department communicates about all INEEL activities, its broad focus includes environmental matters. M\&O contractor Public Affairs is responsible for INEEL facility tours, the Experimental Breeder Reactor I (EBR-I) historic landmark, INEEL news media relations, INEEL's speakers bureau, and a tollfree telephone service for information requests.

Over 2,000 people toured the INEEL in 148 tours in 1998. Tours are individually arranged to visit facilities, which suit the interests of each group. Most tours include a stop at EBR-I and a viewing of the spent fuel storage pools inside INTEC. EBR-I, a National Historic Landmark where electricity was first produced from atomic energy, is open to walk-in visitors from Memorial Day to Labor Day. Visitors gain not only a historical perspective on the development of nuclear reactors, but also an overview of research at the INEEL and the flora and fauna of the sagebrush steppe.

Environmental Science and Research Foundation's Communications and Education Program. The Environmental Science and Research Foundation, as a DOE-ID contractor for environmental monitoring, ecological research and environmental services on the INEEL, aims to improve public understanding of the INEEL's environment through a public education program. This program employs two community monitoring stations; news releases; presentations; interpretive signs; posters; and displays; an Internet presence; a travelers' information radio station; and a newsletter. The content of these communication strategies incorporates recognition of the INEEL's environmental legacy of radioactive materials, which must be properly managed, along with information about the wealth of Idaho's natural heritage present on the Site.

One of the primary responsibilities of the INEEL Offsite Environmental Surveillance Program, conducted by the Foundation, is to communicate environmental data to interested persons. The data, along with easy-to-follow interpretations and explanations of underlying concepts, are incorporated into reports, report summaries, fact sheets, multimedia presentations, and a portable display. The Foundation's portable display describes the environmental surveillance program, and is made available to libraries and other public institutions throughout Idaho. In 1998 it appeared at 13 different locations in Boise, Pocatello, Ashton, Idaho Falls, Roberts, Aberdeen, Twin Falls, Gooding, Burley, and Chubbuck.

As innovative educational tools for the environmental surveillance program, two community monitoring stations were operated at Madison Middle School in Rexburg and Mountain View Middle School in Blackfoot. These stations monitor radioactivity and particulates in the air, environmental radiation levels, and weather conditions, providing some real-time measurements and collection of samples for laboratory analysis. The stations provide community involvement and educational opportunities, as well as actual environmental surveillance data. Data from the stations, along with other data collected within the surveillance program, are being incorporated into science and mathematics lessons.

The Foundation issued 25 news releases about the INEEL's environment to a mailing of about 100 media outlets. During 1998, Foundation personnel gave more than 60 presentations to professional peers, students, civic 
leaders, and other audiences. Several thousand persons attended Foundation presentations.

During 1998, 12 reports were published by the Foundation. Notable among these were Developing the Scientific Basis for Supporting Long-Term Land Management of the INEEL, Potential Use by Sensitive Species of Habitats within and Surrounding Facilities at the INEEL: a Biological Assessment, and the Idaho National Engineering and Environmental Laboratory Site Environmental Report for Calendar Year 1997. In addition to Foundation-published reports, Foundation researchers had 9 technical, peer-reviewed articles and reports published, in press, or submitted.

The Foundation-operated INEEL travelers' information radio station broadcast continuously during 1998 . Located at the intersection of U.S. Highways 20 and 26, the low-powered transmitter broadcasts on a frequency of 530 $\mathrm{AM}$ and is available to persons in the 800,000 vehicles driving on these highways each year. Fourteen messages discussed the environment, natural history, and cultural history of the INEEL and the southeastern Idaho desert.

The Foundation Focus newsletter reached a broad audience with articles about research and monitoring of the INEEL's environment. Circulation was maintained at more than 1,100 in 1998. Significant articles in first three issues of 1998 included an in-depth series entitled "The Site, the Plain, the Aquifer, and the Magic Valley," which analyzed the effects of the INEEL on the aquifer beneath the Snake River Plain.

American Indian Program. DOE- ID is currently focusing on expanding and strengthening the government-to-government relationship with the Shoshone-Bannock Tribes of Fort Hall, Idaho. The Tribes are close neighbors of the INEEL, and are potentially affected by INEEL operations. They have a vested interest in the INEEL, as they have inhabited the Snake River Plain continuously for the past 10,000 years. DOE-ID has negotiated an Agreement-in-Princi- ple with the Tribes that addresses DOE-Indian policy and Shoshone-Bannock Tribal objectives. DOE-ID also funds programs and projects through a cooperative agreement, sponsored by the DOE-HQ Office of Environmental Management, intended to enhance tribal awareness, capabilities, and participation in INEEL activities. The core program addresses environmental management activities including National Environmental Policy Act, transportation, environmental monitoring and training, cultural resources management, and emergency response and management.

DOE also funded the construction of an Emergency Operations Center and a Community Monitoring Station at Fort Hall. The Center is equipped with state-of-the-art communications and tracking equipment and is manned by a fully trained emergency management staff. The Community Monitoring Station provides environmental data to the public and tribal officials for the purposes of outreach and environmental and emergency management. All INEEL air, radiation, and meteorological data collected by the state of Idaho and the National Oceanic Atmospheric Administration (NOAA) is accessible to the Tribes via this system. An educational program is being fostered that will include the Fort Hall schools. This is the only monitoring station of its kind in the DOE system operated by an American Indian tribe. DOE-ID played a key role in determining and ensuring funding, establishing interactions between the Tribes, State, and NOAA, and coaching this project through fruition.

INEEL-sponsored Academic Programs. INEEL and DOE-ID provide paid research and work opportunities for students from Idaho institutions. In 1998, 97 college students, and 136 high school students and teachers were involved. Six Environmental Science and Research Foundation staff members and 23 Foundation university affiliates served as principal investigators on research projects at the INEEL. University personnel included universıty faculty, graduate students, and research assistants, representing 11 universities. Additional 
Foundation staff and university personnel supported other phases of the research. A total of 150 university personnel participated in Foundation research programs during 1998 . The Foundation also provides research and education opportunities for university faculty and students.

\subsection{ENVIRONMENTAL MONITORING}

\section{Purpose and Organization of Monitoring Programs}

Routine operations of INEEL facilities release some materials, which may include both radioactive and non-radioactive contaminants, into the environment. There are two primary routes by which these materials can enter the environment - into the atmosphere as airborne effluents and into surface water and ground water as liquid effluents. Through a variety of exposure pathways (Figure 3-1), contaminants can be transported away from INEEL facilities, where they could potentially impact the surrounding environment and the population living in these areas.

The primary purposes of the various environmental monitoring programs conducted at the INEEL are to evaluate these different exposure pathways and determine what effects may be occurring in the environment. In addition, monitoring provides the information to verify compliance with a variety of applicable environmental protection laws and regulations as described in Chapter 2. DOE Order 5400.1 also requires DOE sites to conduct an environmental monitoring program.

The term environmental monitoring is used to describe two separate activities. Effluent monitoring is the measurement of the waste stream prior to its release to the environment, such as the monitoring of stacks or discharge pipes. Environmental surveillance is the measurement of pollutants in the environment. Surveillance involves determining whether or not pollutants are present or measurable, and if present, in what concentrations they are found.

At the INEEL, environmental monitoring is a collective effort involving a number of different organizations and groups. The remainder of this section provides a summary of the various environmental monitoring activities currently being conducted.

\section{Effluent Monitoring Programs}

Radiological Effluents. Radionuclides in airborne effluents released to the environment were monitored by the contractor responsible for operating each facility. There are currently six airborne emission points for which continuous monitoring for radionuclides is required under the National Emission Standards for Hazardous Air Pollutants. Of these six points, two are at ANL-W, two are at INTEC, and two are at WERF. Other emission points are monitored to verify that they remain below the threshold at which continuous monitoring is required, or for general facility information.

Data from each of these airborne release points are reported monthly to a centralized database, the Radioactive Waste Management Information System, operated by The M\&O contractor. An annual report of the results of the effluent monitoring organizes the data by month, facility, and radionuclide [see Chapter 7].

Radioactive liquid effluents are also monitored at release points and compiled in the Radioactive Waste Management Information System. Most liquid radioactive effluents are discharged into lined ponds and evaporated. No radioactive liquids are released to offsite surface waters, or to streams on the INEEL.

Non-radiological Effluents. Non-radiological airborne effluents originate from the following primary sources at the INEEL:

- calcination of high-level radioactive liquid waste at the New Waste Calcining Facility; 


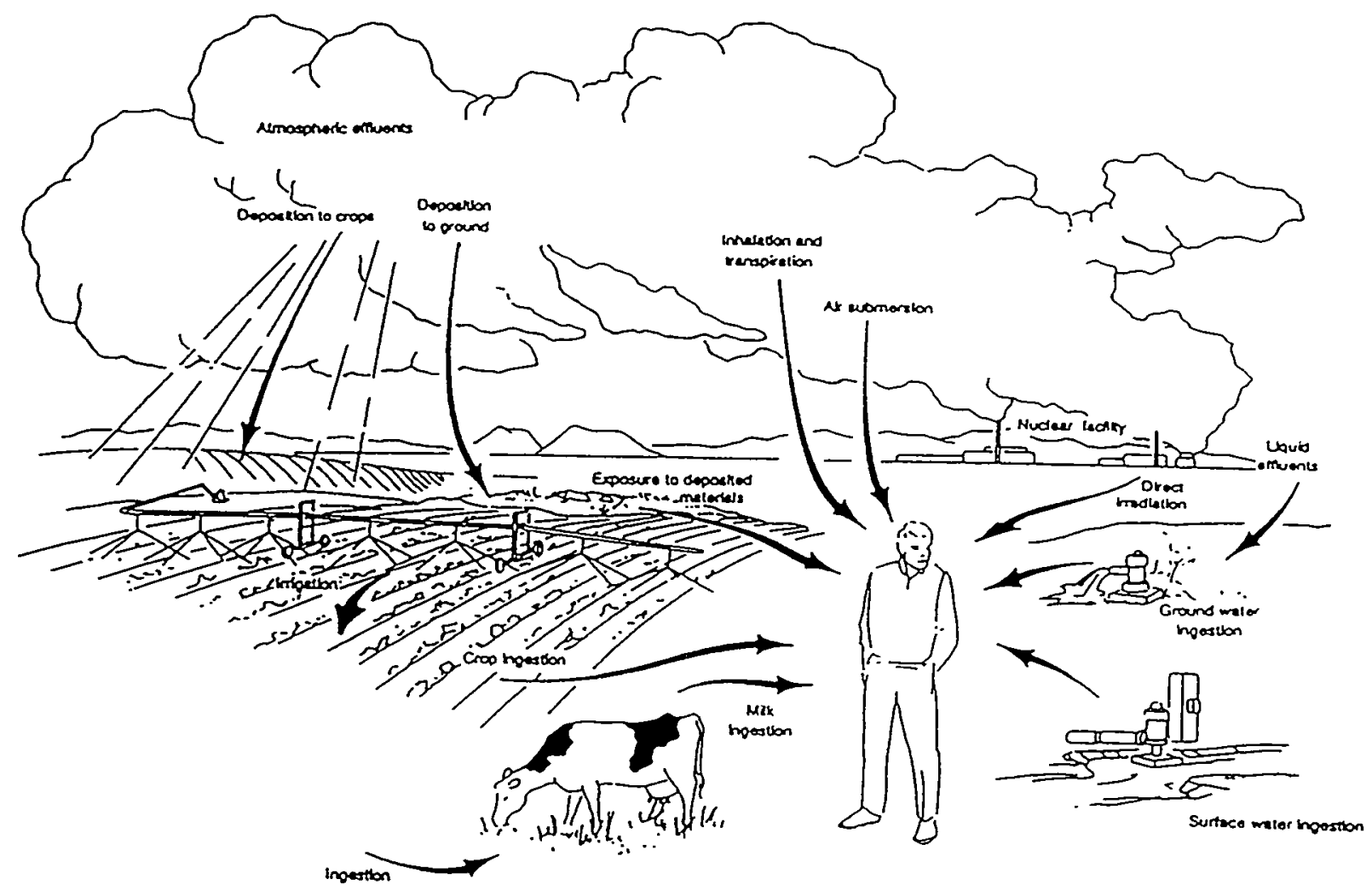

Figure 3-1. Potential Pathways from the INEEL to Humans

- combustion of coal for steam generation at the Coal Fired Steam Generating Facility;

- combustion of fuel oil used for heating INEEL facilities;

- combustion of fuel in engines operating generators;

- motor vehicle exhaust; and

- fugitive dust from a number of activities, including construction and waste burial.

Emissions of nitrogen dioxide are routinely monitored at the New Waste Calcining Facility; sulfur dioxide, nitrogen dioxide, and carbon oxides are monitored at the Coal Fired Steam Generating Facility. Monitoring data for these sources are published in the INEEL Nonradiological Waste Management Information System annual reports. Sulfur dioxide emissions from heating oil usage are calculated from the sulfur content and the quantity of fuel used. Emis- sions of nitrogen dioxide from fuel oil are calculated using EPA emission factors [Reference 3-5] and the amount and type of oil used at each facility. Motor vehicle exhausts and fugitive dusts are not monitored at the source.

At ANL-W, the Experimental Breeder Reactor II auxiliary boilers are monitored monthly, both as an efficiency check and to ensure that emissions of nitrogen oxides and sulfur dioxide remain below the state of Idaho's emission limits. A portable stack emission monitor provides a direct printout of ambient and stack temperature, carbon monoxide, carbon dioxide, sulfur dioxide, nitrogen oxides, and oxygen.

Routine direct disposal of wastes to the Snake River Plain Aquifer ceased in 1984. Liquid wastes are now disposed to sewage lagoons, seepage ponds, industrial waste ponds, industrial waste ditches, and sewage treatment facilities. The liquid effluent monitoring program is presently operated by the $M \& O$ 
contractor for effluent streams at CFA, INTEC, RWMC, TAN, and TRA. In addition, monitoring is performed by the program for INEEL-related facilities located in the city of Idaho Falls. A total of 15 discharge points were routinely monitored for non-radiological parameters in 1998.

ANL-W monitors the Industrial Waste Pond and the Secondary Sanitary Lagoon monthly for non-radiological constituents when these ponds are not frozen or dry.

\section{Facility Monitoring Programs}

Several INEEL facilities conduct environmental surveillance within facility fences and around facility perimeters. The scope of each of these programs varies with the nature of the facility being monitored. One such program, the Radiological Environmental Surveillance Program, monitors M\&O contractor waste management facilities including RWMC and WERF. Samples of air, water, soil, and vegetation are collected. Environmental radiation measurements are also made, and visual inspections of the facilities are conducted. Other monitoring programs are in place at ANL-W, INTEC, and the Specific Manufacturing Capability facility located at TAN.

\section{Drinking Water Programs}

The M\&O contractor Drinking Water Program monitors production and drinking water wells for radiological, chemical, and bacteriological contaminants at all INEEL facilities operated by the M\&O contractor. Currently, 17 wells and 10 distribution systems are routinely monitored. All analyses for the program are conducted using laboratories certified by the state of Idaho or laboratories certified in other states, where this certification is accepted by the state of Idaho. NRF maintains a separate program for sampling drinking water at that facility. Radiological and bacteriological samples from ANL-W are sent to The M\&O con- tractor for analysis. ANL-W conducts a separate program for chemical monitoring.

Radiological Monitoring. Onsite drinking water samples are collected quarterly for radiological analysis from production wells and distribution systems in use at active M\&O contractor facilities. Analyses were performed by Paragon Laboratory during 1998. Each water sample is submitted for gross analyses for alpha and beta-emitting radionuclides. Tritium analyses are also performed on all drinking water samples. Strontium-90 analyses are performed on quarterly samples from drinking water wells in the INTEC area, because water quality monitoring data indicates these wells may be affected by $a^{90} \mathrm{Sr}$ plume.

Bacteriological Monitoring. Potable water at the INEEL is monitored for coliform bacteria monthly by the M\&O contractor Environmental Hygiene Laboratory. If indications of contamination by bacteria are found in a sample, that particular drinking water system is disinfected, resampled, and tested again, until it is clear of bacteria. Corrective action to purify the water may vary among facilities.

Chemical Monitoring. The M\&O contractor Drinking Water Program routinely samples drinking water from wells and distribution systems at facilities at the INEEL for volatile organic compounds. A program to monitor lead and copper in drinking water in accordance with EPA regulations has been in place since 1992. The year 1995 concluded three successive years of monitoring lead and copper levels in drinking water. Since regulatory values were not exceeded, and in accordance with regulations, this monitoring has been reduced to once every three years beginning in 1998 . Chlorinated drinking water systems are also monitored for total trihalomethanes (bromodichloromethane, bromoform, chloroform, and dibromochloro-methane). Additional sampling is conducted for a variety ofinorganic constituents, including metals, nitrates, and dissolved solids. 


\section{Storm Water Monitoring Program}

As one of the requirements of the National Pollutant Discharge Elimination System General Permit effective October 1, 1992, the INEEL was required to develop a storm water monitoring program. Sampling of snow melt and rain runoff began in 1993, and in 1998 included 16 sites at eight INEEL facilities. To meet permit requirements four sites must be sampled at least twice per year if discharge to "waters of the U.S." occurs. The program attempts to sample all locations at least twice yearly.

Samples are collected from storms of at least $0.25 \mathrm{~cm}(0.1 \mathrm{in})$ of precipitation preceded by a minimum of 72 hours without precipitation. Collection, preservation, and analysis of storm water samples are performed in accordance with the National Pollutant Discharge Elimination System Storm Water Sampling Guidance Document and 40 CFR 136.

The general permit does not contain numeric limitations for analytical parameters, except for the runoff from coal piles at INTEC. These are required to have a $\mathrm{pH}$ within the range of 6 to 9 . Other parameters are compared to benchmark concentrations listed in Reference 3-6 to help evaluate the quality of storm water discharges.

\section{Site Environmental Surveillance Program}

General Information. The INEEL M\&O contractor has conducted the Site Environmental Surveillance Program since January 1994. The program has overall responsibility for sampling of air and soil, and measurement of environmental radiation at onsite locations. For comparison purposes, some sampling is also performed at distant locations. A summary of the program in 1998 is provided in Table 3-1.

Analyses for the Site Environmental Surveillance Program were performed primarily by the Radiological Measurement Laboratory located at TRA. A database containing sampling and analytical information is maintained by The
M\&O contractor through the computer support group.

Low-volume Air Samplers. Airborne particulate radioactivity is monitored continuously on the INEEL by The M\&O contractor using a network of low-volume air samplers (Figure 32). The M\&O contractor collects air at 12 locations onsite, and at four offsite locations for comparison purposes. Locations of onsite samplers give adequate coverage in the event of releases of radioactivity from INEEL facilities. Each low-volume air sampler maintains an average air flow of about $50 \mathrm{~L} / \mathrm{min}\left(2 \mathrm{ft}^{3} / \mathrm{min}\right)$ through a set of filters consisting of a $1.2-\mu \mathrm{m}$ pore membrane filter followed by a charcoal cartridge. The filters are 99 percent efficient for airborne particulate radioactivity and iodides.

The particulate filters from the low-volume air samplers are collected and analyzed weekly. All the charcoal cartridges are evaluated individually each week for ${ }^{131}$ I by gamma spectrometry. Particulate filters are analyzed after waiting a minimum of four days to allow the naturally occurring, short-lived radon and thoron daughters to decay. Analyses for gross (nonspecific) alpha and gross beta activity are performed with a proportional counter.

Specific radionuclide analyses are more sensitive than gross alpha and gross beta analyses for detecting concentrations of humanmade radionuclides in air. The particulate filters of the low-volume samplers are composited by location at the end of each quarter, and all composites are analyzed for specific radionuclides by gamma spectrometry. Composites are then submitted for analyses for alpha-emitting radionuclides $\left({ }^{238} \mathrm{Pu},{ }^{239 / 240} \mathrm{Pu}\right.$, and ${ }^{241} \mathrm{Am}$ ) and ${ }^{90} \mathrm{Sr}$. The analyses for alphaemitting nuclides use chemical separation techniques followed by alpha spectrometry; for ${ }^{90} \mathrm{Sr}$, the chemical separation is followed by beta counting. 
Table 3-1. M\&O Contractor Site Environmental Surveillance Radiological Program Summary (1998)

\begin{tabular}{|c|c|c|c|c|}
\hline \multirow{2}{*}{$\begin{array}{l}\text { Medium Sampled } \\
\text { Air (Low-Volume) }\end{array}$} & \multirow[b]{2}{*}{$\begin{array}{l}\text { Analysis } \\
\text { Gross alpha }\end{array}$} & \multicolumn{2}{|c|}{ Locations and Frequency } & \multirow{2}{*}{$\begin{array}{c}\text { Approximate } \\
\text { Minimum } \\
\text { Detectable } \\
\text { Concentration } \\
1 \times 10^{-15} \mu \mathrm{Ci} / \mathrm{mL}\end{array}$} \\
\hline & & $\begin{array}{l}\text { Onsite } \\
12 \text { weeklv }\end{array}$ & $\begin{array}{l}\text { Offsite } \\
4 \text { weekly }\end{array}$ & \\
\hline & Gross beta & 12 weekly & 4 weekly & $5 \times 10^{-15} \mu \mathrm{Ci} / \mathrm{mL}$ \\
\hline & Specific gamma & 12 quarterly & 4 quarterly & 1 to $10 \times 10^{-15} \mu \mathrm{Ci} / \mathrm{mL}$ \\
\hline & $\mathrm{Pu}$ & 12 quarterly & 4 quarterly & $2 \times 10^{-18} \mu \mathrm{Ci} / \mathrm{mL}$ \\
\hline & Am & 12 quarterly & 4 quarterly & $2 \times 10^{-18} \mu \mathrm{Ci} / \mathrm{mL}$ \\
\hline & ${ }^{90} \mathrm{Sr}$ & 12 quarterly & 4 quarterly & $3.5 \times 10^{-17} \mu \mathrm{Ci} / \mathrm{mL}$ \\
\hline & Particulate matter & 12 quarterly & 4 quarterly & $10 \mu \mathrm{g} / \mathrm{m}^{3}$ \\
\hline Air (Tritium) & ${ }^{3} \mathrm{H}$ & 2 at 1 to 2 /quarter & ---- & $1 \times 10^{-11} \mu \mathrm{Ci} / \mathrm{mL}$ \\
\hline Soil ${ }^{a}$ & Specific gamma & Varies annually & $-\ldots$ & $1 \times 10^{-7} \mu \mathrm{Ci} / \mathrm{g}$ \\
\hline & $\mathrm{Pu}$ & Varies annually & $\cdots$ & $3 \times 10^{-9} \mu \mathrm{Ci} / g$ \\
\hline & Am & Varies annually & -.--- & $3 \times 10^{-9} \mu \mathrm{Ci} / \mathrm{g}$ \\
\hline & ${ }^{90} \mathrm{Sr}$ & Varies annually & $\cdots$ & $6 \times 10^{-8} \mu \mathrm{Ci} / \mathrm{g}$ \\
\hline $\begin{array}{l}\text { Direct Radiation Exposure } \\
\text { (TLDs) }\end{array}$ & lonizing Radiation & 135 semiannually & 13 semiannually & $5 \mathrm{mR}$ \\
\hline $\begin{array}{l}\text { Direct Radiation Exposure } \\
\text { (Radiation Surveys) }\end{array}$ & Gamma Radiation & $\begin{array}{l}\text { Facilities }^{b} \\
\text { INEEL Roads }\end{array}$ & $-\cdots$ & Not Applicable \\
\hline
\end{tabular}

Atmospheric Moisture Samplers. Samplers for tritium in water vapor in the atmosphere are located at the EFS and Van Buren locations on the INEEL. In these samplers, air is passed through a column of molecular sieve at a rate of approximately $0.5 \mathrm{~L} / \mathrm{min}\left(1 \mathrm{ft}^{3} / \mathrm{hr}\right)$. Water vapor in the air is absorbed by the molecular sieve in the column; columns are changed when the molecular sieve absorbs sufficient moisture to obtain a sample (typically from one to three times per quarter). Tritium concentrations are then determined by liquid scintillation counting of the water extracted from the molecular sieve columns.

Nitrogen Dioxide/Sulfur Dioxide Monitoring. To fulfill one of the conditions specified in the Permit to Construct, Idaho Chemical Processing Plant Nitrogen Oxide Sources, two nitrogen oxide monitoring stations (which measure NO and $\mathrm{NO}_{2}$, collectively called $\mathrm{NO}_{x}$ ) are operated by The $M \& O$ contractor. These are located near the intersection of U.S. Highway 20/26 and Van Buren Boulevard and at EFS. The analyzers used are designated as EPA equivalent methods. One EPA equivalent method sulfur dioxide analyzer is operated at the Van Buren location in addition to the nitrogen dioxide analyzer.

Environmental Dosimeters. Environmental dosimeters, known as thermoluminescent dosimeters (TLDs), are used to measure ionizing radiation exposures. The TLDs measure ionizing radiation exposures from natural radioactivity in the air and soil, cosmic radiation from space, fallout from nuclear weapons tests, radioactivity from fossil fuel burning, and radioactive effluents from INEEL operations and other industrial processes. 
At each location, a dosimeter card contain-

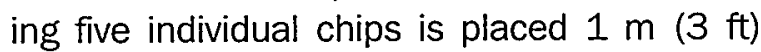
above ground level. The $M \& O$ contractor maintained dosimeters at 13 offsite locations and 135 locations on the INEEL. The dosimeter card at each location is changed semiannually, and cumulative gamma radiation is measured by the M\&O contractor Dosimetry Unit.

\section{Offsite Environmental Surveillance Program}

General Information. The Environmental Science and Research Foundation is a nonprofit organization which conducts environmental monitoring, environmental education, ecological research, and environmental services independent of the $M \& O$ contractor at the INEEL. The Foundation has, since April 1994, performed the INEEL Offsite Environmental Surveillance Program for DOE-ID (Table 3-2).

The Environmental Science and Research Foundation uses independent offsite laboratories to perform analyses for the environmental surveillance program. The majority of radiological analyses, including gross alpha/ gross beta, tritium, and gamma spectrometry analyses, are conducted by the Idaho State University Environmental Assessment Laboratory. Radiochemical analyses, such as ${ }^{90} \mathrm{Sr}$ and transuranics, are performed at Quanterra Inc., an independent commercial laboratory. Analyses for the Interagency Monitoring of Protected Visual Environments (IMPROVE) program are performed at the University of California, Davis Crocker Nuclear Laboratory. The University of Toronto's IsoTrace Laboratory conducted ${ }^{129} \mathrm{I}$ analyses in 1998.

Low-volume Air Samplers. The Foundation maintains a network of low-volume air samplers (Figure 3-2) to monitor for airborne radioactivity. Twelve samplers are located at offsite locations. In addition, three samplers are operated on the INEEL for comparison purposes. Each low-volume air sampler maintains an average air flow of about $50 \mathrm{~L} / \mathrm{min}\left(2 \mathrm{ft}^{3} / \mathrm{min}\right)$ through a set of filters consisting of a $1.2-\mu \mathrm{m}$ pore mem- brane filter followed by a charcoal cartridge. The filters are 99 percent efficient for airborne particulate radioactivity and iodides.

The particulate filters from the low-volume air samplers are collected and analyzed weekly. Charcoal cartridges are evaluated in batches of up to eight cartridges for ${ }^{131}$ I using gamma spectrometry. If any activity is noted in a batch, each filter in the batch can then be recounted individually.

Particulate filters are analyzed weekly for gross alpha and gross beta concentrations using an automatic proportional counting system. Filters are analyzed after waiting a minimum of four days to allow naturally occurring radionuclides to decay. Gross alpha and gross beta analyses are used as a screening technique, to provide timely information on levels of radioactivity in the environment.

The particulate filters from the low-volume samplers are composited by location at the end of each quarter and analyzed for specific radionuclides. All composites are analyzed for specific gamma-emitting nuclides by gamma spectrometry. Selected composites are then submitted for analyses for transuranic radionuclides $\left({ }^{238} \mathrm{Pu},{ }^{239 / 240} \mathrm{Pu}\right.$, and $\left.{ }^{241} \mathrm{Am}\right)$ or ${ }^{90} \mathrm{Sr}$. The analyses for transuranic nuclides use chemical separation techniques followed by alpha spectrometry; for ${ }^{90} \mathrm{Sr}$, the chemical separation is followed by beta counting.

Measurements of total suspended particulates are performed on the particulate filters from the low-volume filters. Clean filters are weighed at the beginning of each quarter and filter composites are weighed at the end of the quarter. The concentration of total suspended particulates is calculated by dividing the amount of material collected on the filters by the total volume of air passing though the filters.

Atmospheric Moisture Samplers. Samplers to collect atmospheric water vapor for tritium analyses are located in Idaho Falls, Blackfoot, Atomic City, and Rexburg. In these samplers, 


\section{Table 3-2. Environmental Science and Research Foundation Environmental Surveillance Radiological Program Summary (1998)}

$\begin{array}{lc}\text { Medium Sampled } & \text { Type of Analysis } \\ \text { Air (Low-Yolume) } & \text { Gross alpha } \\ \text { (particulate filter) } & \text { Gross beta } \\ & \text { Specific gamma } \\ & { }^{238} \mathrm{Pu} \\ { }^{239 / 240} \mathrm{Pu} \\ { }^{241} \mathrm{Am} \\ { }^{90} \mathrm{Sr}\end{array}$

Air (charcoal cartridge)

Air $\left(\mathrm{PM}_{10}\right)$

Air (IMPROVE)

Air

(Atmospheric Moisture)

Air (Precipitation)

Drinking Water

Surface Water

Animal Tissue (Sheep) ${ }^{a}$

Animal Tissue (Game)

Foodstuffs (Milk)

Foodstuffs (Potatoes)

Foodstuffs (Wheat)

Foodstuffs (Lettuce)

Soil

Direct Radiation Exposure (TLDs)

Particulate matter 13i!

$$
\mathrm{H}, \mathrm{Na}-\mathrm{Pb}, \mathrm{PM}_{25}
$$$$
{ }^{3} \mathrm{H}
$$

${ }^{3} \mathrm{H}$

Gross alpha

Gross beta

${ }^{3} \mathrm{H}$

Gross alpha

Gross beta

${ }^{3} \mathrm{H}$

Specific gamma

Specific gamma

13i]

131

129

${ }^{90} \mathrm{Sr}$

${ }^{3} \mathrm{H}$

Specific gamma

${ }^{90} \mathrm{Sr}$

Specific gamma

${ }^{90} \mathrm{Sr}$

Specific gamma

${ }^{90} \mathrm{Sr}$

Specific gamma

$\mathrm{Pu}$

Am

${ }^{90} \mathrm{Sr}$

lonizing

Radiation
Number of Locations and Frequency

$$
\begin{aligned}
& \text { Onsite } \\
& 3 \text { weekly } \\
& 3 \text { weekly } \\
& 3 \text { quarterly } \\
& 1-2 \text { quarterly } \\
& 1-2 \text { quarterly } \\
& 1-2 \text { quarterly } \\
& 1-2 \text { quarterly } \\
& 3 \text { quarterly } \\
& 3 \text { weekly } \\
& \text { None } \\
& 1 \text { biweekly } \\
& \text { None }
\end{aligned}
$$

1 weekly/ 1 monthly

None

None

None

None

None

None

4 annually

Varies annually

None

None

None

None

None

None

None

None

None

None

None

None

None

None

None

\section{Offsite \\ 12 weekly \\ 12 weekly}

12 quarterly

4 quarterly

4 quarterly

4 quarterly

4 quarterly

12 quarterly

12 weekly

3 weekly

1 biweekly

4 locations,

2 to 4/quarter

1 monthly

13 semiannually

13 semiannually

13 semiannually

5 quarterly

5 quarterly

2 annually

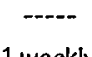

1 weekly

9 monthly

5 quarterly

9 annually

9 annually

8 annually

8 annually

11 annually

11 annually

9 annually

9 annually

12 biennially

12 biennially

12 biennially

12 biennially
5 quarterly
Minimum Detectable

Concentration

$1 \times 10^{-15} \mu \mathrm{Ci} / \mathrm{mL}$

$3 \times 10^{-15} \mu \mathrm{Ci} / \mathrm{mL}$

$3 \times 10^{-16} \mu \mathrm{Ci} / \mathrm{mL}$

$2 \times 10^{-18} \mu \mathrm{Ci} / \mathrm{mL}$

$3 \times 10^{-18} \mu \mathrm{Ci} / \mathrm{mL}$

$2 \times 10^{-18} \mu \mathrm{Ci} / \mathrm{mL}$

$3 \times 10^{-17} \mu \mathrm{Ci} / \mathrm{mL}$

$10 \mu \mathrm{g} / \mathrm{m}^{3}$

$4 \times 10^{-15} \mu \mathrm{Ci} / \mathrm{mL}$

$4 \times 1 O^{-12} \mu \mathrm{Ci} / \mathrm{mL}$

$1 \times 10^{-7} \mu \mathrm{Ci} / \mathrm{mL}$

$3 \times 10^{-9} \mu \mathrm{Ci} / \mathrm{mL}$

$2 \times 10^{-9} \mu \mathrm{Ci} / \mathrm{mL}$

$1 \times 10^{-7} \mu \mathrm{Ci} / \mathrm{mL}$

$3 \times 10^{-9} \mu \mathrm{Ci} / \mathrm{mL}$

$2 \times 10^{-9} \mu \mathrm{Ci} / \mathrm{mL}$

$1 \times 10^{-7} \mu \mathrm{Ci} / \mathrm{mL}$

$5 \times 10^{.9} \mu \mathrm{Ci} / \mathrm{g}$

$5 \times 10^{-9} \mu \mathrm{Ci} / \mathrm{g}$

$2 \times 10^{-9} \mu \mathrm{Ci} / \mathrm{mL}$

$2 \times 10^{-9} \mu \mathrm{Ci} / \mathrm{mL}$

$5-25 \times 10^{6}$ atoms $/ \mathrm{g}^{c}$

$3 \times 10^{-10} \mu \mathrm{Ci} / \mathrm{mL}$

$1 \times 10^{-7} \mu \mathrm{Ci} / \mathrm{mL}$

$4 \times 10^{-9} \mu \mathrm{Ci} / \mathrm{g}$

$5 \times 10^{-9} \mu \mathrm{Ci} / \mathrm{g}$

$4 \times 10^{-9} \mu \mathrm{Ci} / \mathrm{g}$

$5 \times 10^{-9} \mu \mathrm{Ci} / \mathrm{g}$

$1 \times 10^{-7} \mu \mathrm{Ci} / \mathrm{g}$

$2 \times 10^{-7} \mu \mathrm{Ci} / \mathrm{g}$

$4 \times 10^{-8} \mu \mathrm{Ci} / \mathrm{g}$

$2 \times 10^{-9} \mu \mathrm{Ci} / \mathrm{g}$

$3 \times 10^{-9} \mu \mathrm{Ci} / \mathrm{g}$

$9 \times 10^{-8} \mu \mathrm{Ci} / \mathrm{g}$

None

14 semiannually

$5 \mathrm{mR}$

- "Onsite" sheep grazed onsite for at least four weeks before being sampled. "Offsite" animals have never grazed onsite and serve as controls.

- Only road-killed game animals are sampled onsite. No controls are generally collected except for specific ecological studies.

- Minimum detectable concentration for iodine-129 by accelerator mass spectrometry is in terms of grams of processed dry milk solids 


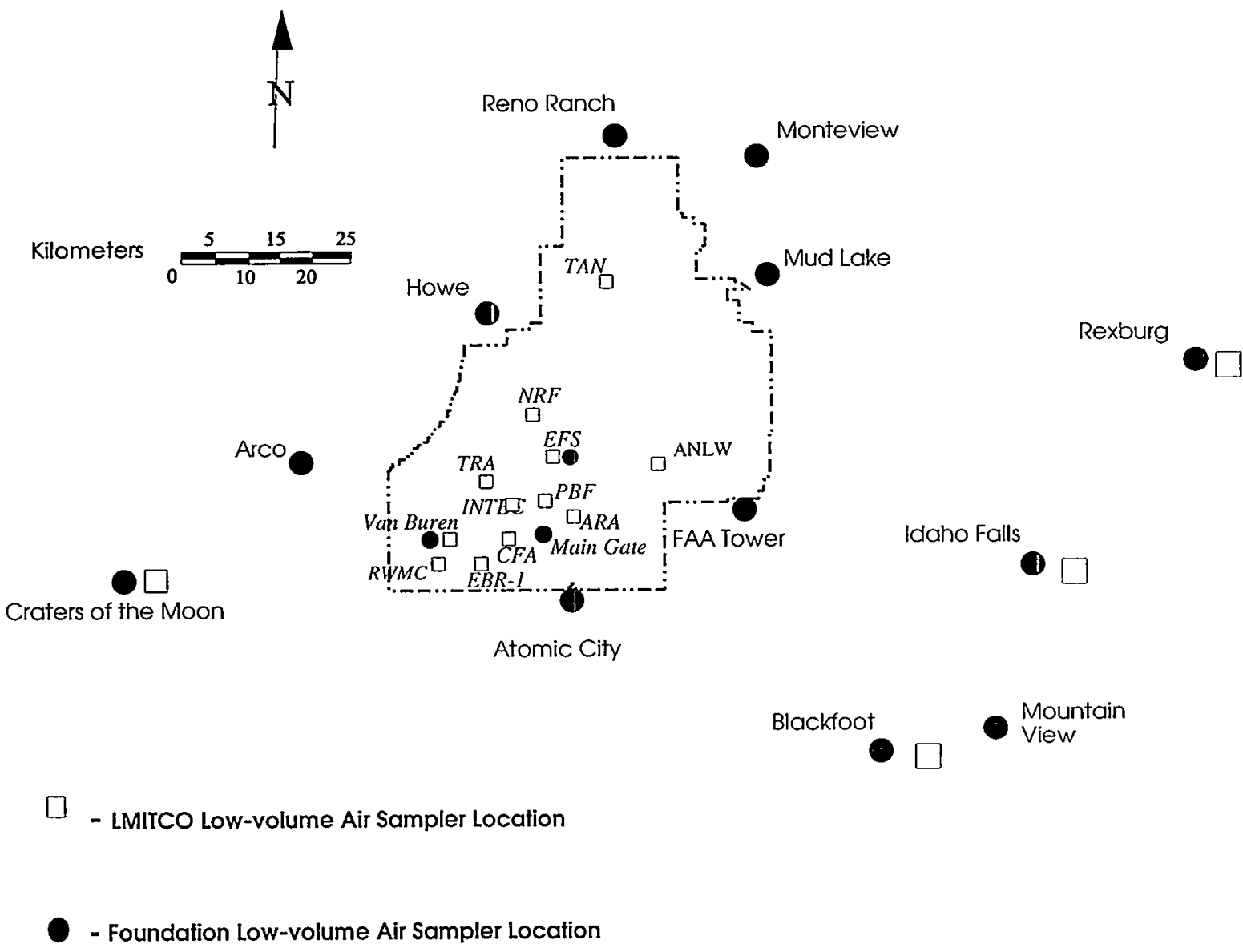

Figure 3-2. Low-volume Air Sampler Locations

air is passed through a column of silica gel at a rate of approximately $0.3 \mathrm{~L} / \mathrm{min}\left(0.01 \mathrm{ft}^{3} / \mathrm{min}\right)$. Water vapor in the air is absorbed by the gel in the column; columns are changed when the gel absorbs sufficient moisture to obtain a sample (typically from one to three times per quarter). Tritium concentrations are then determined by liquid scintillation counting of the water extracted from the silica gel columns.

Precipitation. Monthly precipitation samples are collected on the INEEL at CFA and at the offsite location of Idaho Falls. In addition, weekly samples are collected at EFS when available. A portion of each precipitation sample is submitted for tritium analysis by liquid scintillation counting.
Fine Particulates. The Foundation established samplers which selectively measure the concentration of fine particulates less than 10 $\mu \mathrm{m}$ in aerodynamic diameter, known as $\mathrm{PM}_{10}$ samplers, as part of the Community Monitoring Stations in Rexburg and Blackfoot. Sampling at these stations began in 1996. An additional sampler began operation in Atomic City in March 1997. Fine particulate samplers operate for 24 hours, midnight to midnight, every sixth day. Clean quartz fiber filters are weighed before and after sampling to determine the amount of material collected.

IMPROVE Samplers. The National Park Service, in cooperation with other federal land management agencies (U.S. Forest Service, 
U.S. Fish \& Wildlife Service, Bureau of Land Management) began the IMPROVE program in 1985. This program was an extension of an earlier Environmental Protection Agency program to measure fine $(<2.5 \mu \mathrm{m})$ particles, the largest cause of visibility degradation.

In May 1992, one IMPROVE sampler was established at CFA on the INEEL and a second was located at Craters of the Moon National Monument, as part of the nationwide network. The two samplers each collect two 24-hour samples weekly of fine particulates $<2.5 \mu \mathrm{m}$ in diameter. Analyses are performed for mass, optical absorption, hydrogen, carbon, nitrogen, and oxygen plus elements from sodium through lead on the periodic table.

Water. In 1998 the Environmental Science and Research Foundation collected semiannual drinking water samples from boundary and distant communities, and surface water samples from the Snake River at Idaho Falls and Bliss. In addition, quarterly drinking water and surface water samples were collected from the Magic Valley area. Each water sample collected was submitted for gross analyses for alpha and beta emitting radionuclides, as well as for tritium analysis using liquid scintillation.

Milk. Milk samples were collected from both large corporate and single-family dairies (Figure 3-3). A 4-L (1-gal) sample was obtained from each location monthly, except in Idaho Falls where a sample was collected weekly. Milk from each location was analyzed for ${ }^{131}$, and one analysis for ${ }^{90} \mathrm{Sr}$ and tritium at each location was performed during the year.

Lettuce. Lettuce samples were obtained from private gardens in communities in the vicinity of the INEEL. Samples were washed to remove soil (as in normal food preparation), dried, reduced to a powdered form, and weighed. All lettuce samples were analyzed for ${ }^{90} \mathrm{Sr}$ and gamma-emitting radionuclides.

Wheat. Wheat samples were collected from grain elevators in the region surrounding the
INEEL. All wheat samples were analyzed for ${ }^{90} \mathrm{Sr}$ and gamma-emitting radionuclides.

Potatoes. Potato samples were collected from storage warehouses in the INEEL vicinity. The samples, with cleaned skins included, were processed and weighed. All potato samples were analyzed for ${ }^{90} \mathrm{Sr}$ and gamma-emitting radionuclides.

Sheep. Samples of tissue (muscle, liver, and thyroid) were collected from sheep grazing on the INEEL. Control samples were collected from Blackfoot. The muscle and liver were processed and analyzed by gamma spectrometry. The thyroid was placed in a vial and analyzed specifically for ${ }^{131}$.

Game Animals. Selected tissues (muscle, liver, and thyroid) were collected from game animals accidentally killed on INEEL roads. Thyroid samples were placed in viais and analyzed by gamma spectrometry specifically for ${ }^{131} \mathrm{I}$. Muscle and liver samples were processed, placed in a plastic container, and weighed prior to gamma spectrometry analysis.

Waterfowl samples were collected from waste disposal ponds at four facilities on the INEEL to evaluate the potential for exposure to members of the public who might consume these game animals. Control samples were also taken in areas distant from the INEEL. Waterfowl samples are separated into an external portion (consisting of the skin and feathers), edible portion (muscle tissue), and remainder portion. All samples are analyzed by gamma spectrometry. Selected samples are also analyzed for ${ }^{90} \mathrm{Sr}$ and transuranic radionuclides.

Soil. To establish background levels of natural and fallout radioactivity in surface soil, and to assess any potential buildup of radioactivity from INEEL operations, soil samples are collected from distant and boundary locations in each even-numbered year. Twelve locations were sampled during 1998.

Environmental Dosimeters. Environmental dosimeters, commonly called thermoluminescent dosimeters (TLDs), were used to 


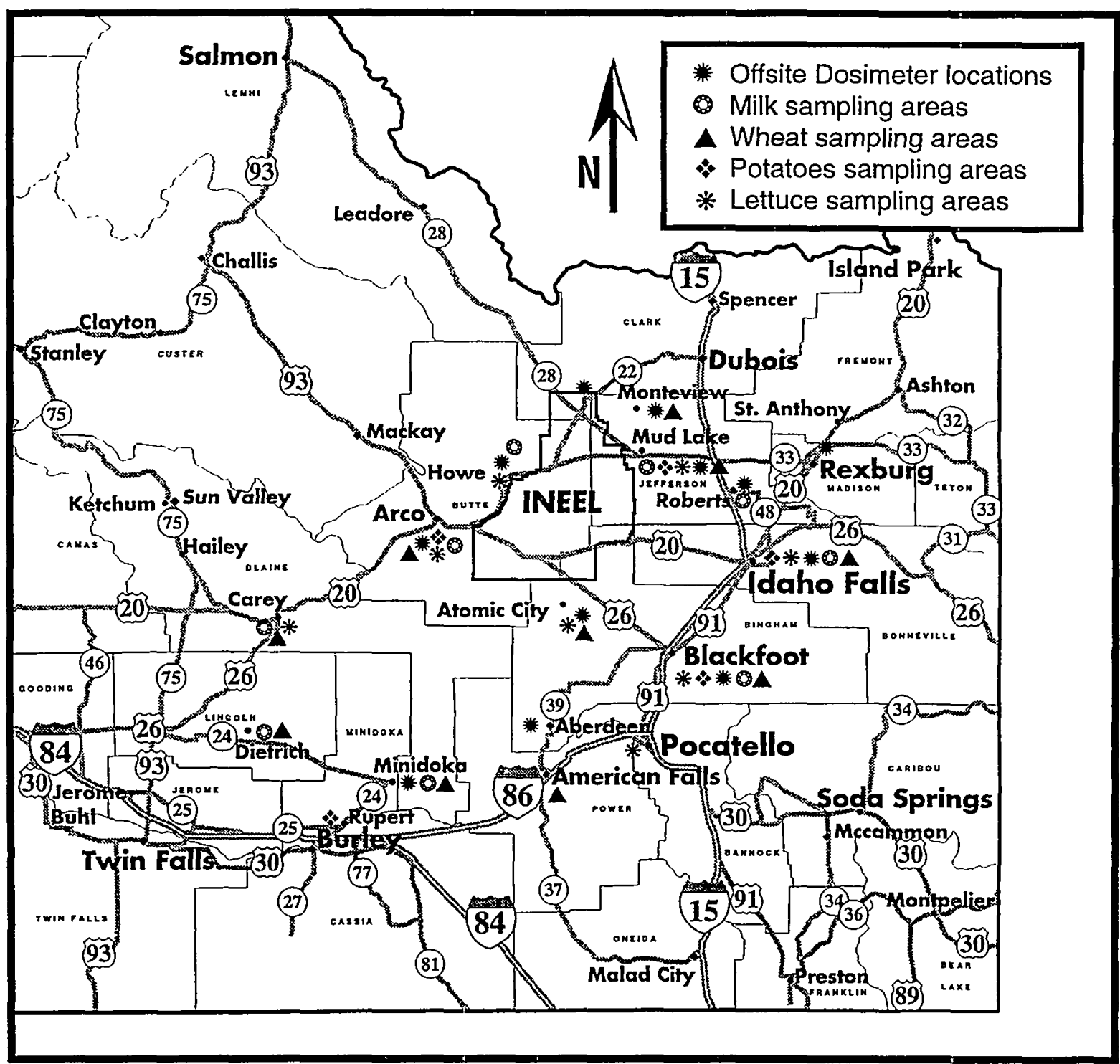

Figure 3.3 Offsite Foodstuff Sampling and Environmental Dosimeter Locations

measure ionizing radiation exposures at offsite locations. The TLDs measure ionizing radiation exposures from all sources, including natural radioactivity, cosmic radiation, fallout from nuclear weapons tests, radioactivity from fossil fuel burning, and radioactive effluents from INEEL operations and other industrial processes.

At each location, a dosimeter card containing five individual chips was placed $1 \mathrm{~m}(3 \mathrm{ft})$ above ground level. Dosimeters were changed twice per year at each of 13 sampling locations surrounding the INEEL (Figure 3-3).

\section{USGS Ground-water Monitoring Program}

The USGS INEEL Project Office has conducted ground- and surface water monitoring at the Site since 1949 . The USGS currently maintains 125 aquifer observation wells on or near the INEEL. An additional 45 wells are available for sampling perched ground-water bodies. In addition, more than 120 auger holes have 
been drilled to monitor shallow perched groundwater bodies (see Chapter 6).

The USGS monitors water levels in wells and radiological and non-radiological substances in water from their observation wells and auger holes on schedules ranging from monthly to annually (Table 3-3). The USGS also conducts special studies of the groundwater of the Snake River Plain. A summany of these studies is provided in Chapter 6 of this report. These special studies provide more specific geological and hydrological information on the flow and recharge of the aquifer and the movements of radioactive and non-radioactive substances in the ground water.

Chemical Monitoring. Water samples from selected onsite production wells and groundwater monitoring wells are collected by USGS personnel on schedules ranging from monthly to annually. These samples are submitted to the USGS National Water Quality Laboratory in Arvada, Colorado, for analysis of 60 purgeable organic compounds. Sampling for trace elements is also performed by the USGS. Other parameters in ground water are measured based on the needs of special studies that are being conducted by the organization. Results of these studies are published in USGS Water Resources Investigation Reports and Open-File Reports on a periodic basis.

\section{Meteorological Monitoring Program}

Meteorological monitoring began at the INEEL in 1949. The NOAA Air Resources Laboratory, located in Idaho Falls, currently maintains a network of 33 meteorological stations in the vicinity of the Site. These stations provide continuous measurement of a variety of parameters, including temperature at two or three levels, wind direction and speed, relative humidity, and precipitation. In addition, continuous measurements are also made using a wind-profiling radar system and radio acoustic sounding system located on the INEEL. Data from the meteorological stations, radar wind- profiler, and acoustic sounder are telemetered to the NOAA Idaho Falls facility, where they are stored in a computerized archive.

\section{INEEL Oversight Program}

Introduction. Since 1990, the state of Idaho has operated an environmental surveillance program as part of the INEEL Oversight Program. This program includes the collection and analysis of air, precipitation, atmospheric moisture, water, soil and milk samples on and around the INEEL. In addition, the program has a network of pressurized ion chambers, electret ion chambers, and environmental dosimeters. Many of these samples are taken simultaneously with other organizations performing environmental surveillance, or are at sites colocated with other organizations. All radiological analyses are performed by the Idaho State University Environmental Monitoring Laboratory. The Oversight Program recently completed a report detailing results obtained by the program [Reference 3-7]. 
Table 3-3. U.S. Geological Survey Ground-Water Monitoring Program Summary (1998)

\begin{tabular}{|c|c|c|c|c|c|c|}
\hline \multirow[b]{2}{*}{ Constiuent } & \multirow[b]{2}{*}{ Frequency } & \multicolumn{2}{|c|}{ Groundwater } & \multicolumn{2}{|c|}{ Surface Water } & \multirow[b]{2}{*}{$\begin{array}{c}\text { Minimum } \\
\text { Detectable } \\
\text { Concentration a }\end{array}$} \\
\hline & & $\begin{array}{l}\text { Number } \\
\text { of Sites }\end{array}$ & $\begin{array}{l}\text { Number of } \\
\text { Samples }\end{array}$ & $\begin{array}{l}\text { Number } \\
\text { of Sites }\end{array}$ & $\begin{array}{l}\text { Number of } \\
\text { Samples }\end{array}$ & \\
\hline$\overline{\text { Gross alpha }}$ & $\overline{\text { Semiannually }}$ & 43 & 86 & 4 & 8 & $3 \times 10^{-9}$ \\
\hline Gross beta & Semiannually & 43 & 86 & 4 & 8 & $4 \times 10^{-9}$ \\
\hline \multirow[t]{3}{*}{ Tritium } & Quarterly & 30 & 120 & - & - & $4 \times 10^{-7}$ \\
\hline & Semiannually & 95 & 190 & 7 & 14 & \\
\hline & Annually & 39 & 39 & - & - & \\
\hline Specific & Quarterly & 5 & 20 & - & - & 1 to $10 \times 10^{-9}$ \\
\hline \multirow[t]{2}{*}{ gamma } & Semiannually & 58 & 116 & 4 & 8 & \\
\hline & Annually & 26 & 26 & - & - & \\
\hline \multirow[t]{3}{*}{${ }^{90} \mathrm{Sr}$} & Quarterly & 25 & 100 & - & - & $5 \times 10^{-9}$ \\
\hline & Semiannually & 60 & 120 & - & - & \\
\hline & Annually & 33 & 33 & - & - & \\
\hline \multirow[t]{3}{*}{ Americium } & Quarterly & 5 & 20 & - & - & $5 \times 10^{-11}$ \\
\hline & Semiannually & 13 & 26 & - & - & \\
\hline & Annually & 3 & 3 & - & - & \\
\hline \multirow[t]{3}{*}{ Plutonium } & Quarterly & 5 & 20 & - & - & $4 \times 10^{-11}$ \\
\hline & Semiannually & 13 & 26 & - & - & \\
\hline & Annually & 3 & 3 & - & - & \\
\hline \multirow[t]{3}{*}{ Conductance } & Quarterly & 30 & 120 & - & - & Not applicable \\
\hline & Semiannually & 96 & 192 & 7 & 14 & \\
\hline & Annually & 39 & 39 & - & - & \\
\hline \multirow[t]{3}{*}{ Sodium ion } & Quarterly & 2 & 8 & - & - & 0.1 \\
\hline & Semiannually & 46 & 92 & - & - & \\
\hline & Annually & 98 & 98 & - & - & \\
\hline \multirow[t]{3}{*}{ Chloride ion } & Quarterly & 30 & 120 & - & - & 0.1 \\
\hline & Semiannually & 95 & 190 & 7 & 14 & \\
\hline & Annually & 39 & 39 & - & - & \\
\hline Nitrates & Semiannually & 42 & 84 & - & - & 0.05 \\
\hline (as nitrogen) & Annually & 67 & 67 & - & - & \\
\hline \multirow[t]{4}{*}{ Sulfate } & Quarterly & 2 & 8 & - & - & 0.1 \\
\hline & Triennially & 3 & 9 & - & - & \\
\hline & Semiannually & 10 & 20 & - & - & \\
\hline & Annually & 103 & 103 & - & - & \\
\hline Chromium & Quarterly & 4 & 16 & - & - & 0.005 \\
\hline \multirow[t]{2}{*}{ (dissolved) } & Semiannually & 71 & 142 & - & - & \\
\hline & Annually & 17 & 17 & - & - & \\
\hline Purgeable & Monthly & 1 & 12 & - & - & 0.0002 \\
\hline organic & Quarterly & 4 & 16 & - & - & \\
\hline \multirow[t]{2}{*}{ compounds ${ }^{c}$} & Semiannually & 17 & 34 & - & - & \\
\hline & Annually & 7 & 7 & - & - & \\
\hline $\begin{array}{l}\text { Total organic } \\
\text { carbon }\end{array}$ & Annually & 42 & 42 & - & - & 0.1 \\
\hline Trace elements & Semiannually & 9 & 18 & - & - & varies \\
\hline
\end{tabular}




\section{Chapter 4 \\ Environmental Radiological Program Results}

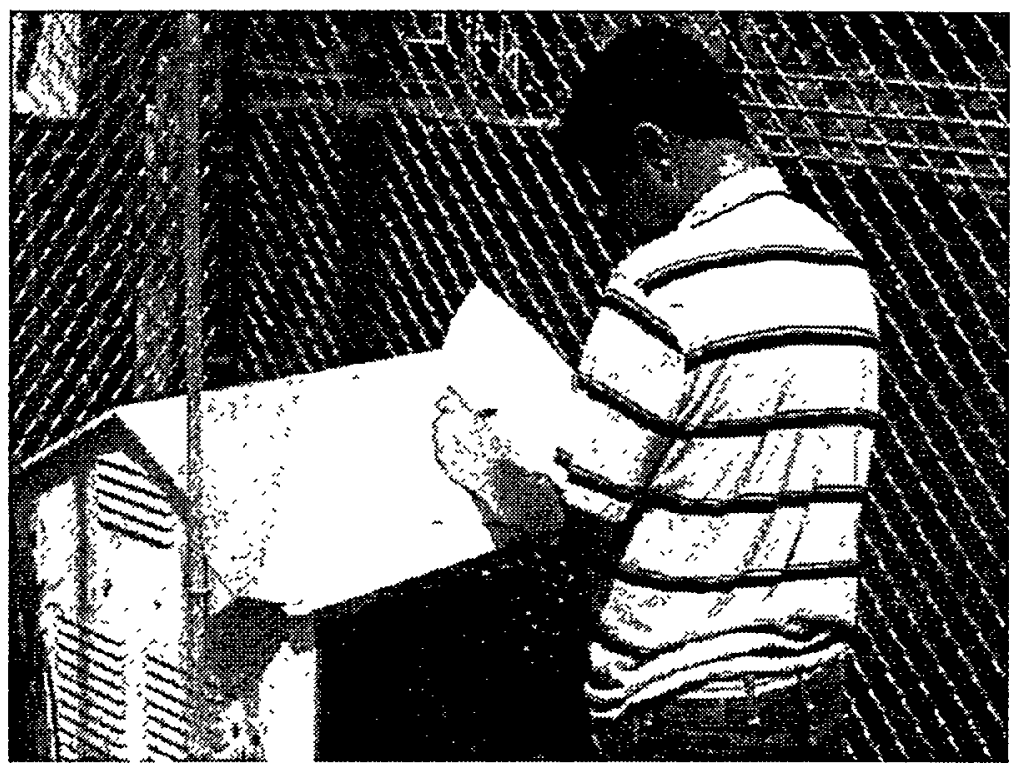




\section{ENVIRONMENTAL RADIOLOGICAL PROGRAM RESULTS}

\subsection{AIR}

\section{Low-volume Charcoal Cartridges}

Both the Environmental Science and Research Foundation and the M\&O contractor collect charcoal cartridges weekly and scan each week's filters in a batch by gamma spectroscopy for gamma-emitting radionuclides. If any traces of any anthropogenic radionuclide are detected, the filters are individually analyzed. During 1998 the M\&O contractor analyzed a total of 984 cartridges specifically for ${ }^{131} \mathrm{I}$. The Foundation analyzed 914 cartridges. lodine-131 was not detected in any sample at a minimum detectable concentration of $4 \times 10^{-15} \mu \mathrm{Ci} / \mathrm{mL}$.

\section{Low-volume Gross Alpha}

Gross alpha concentrations found in Foundation samples, both onsite and offsite, were consistently higher than those found in M\&O contractor samples at common locations (Table 4-1). This difference is likely due to differences in laboratory analytical techniques and instrumentation. Both sets of data indicated gross alpha concentrations were generally higher at distant locations than at boundary and onsite locations.

\section{Low-volume Gross Beta}

As with gross alpha, gross beta concentrations in Foundation samples were consistently higher than those found in $M \& 0$ contractor samples (Table 4-2). Chapter 9 includes a comparison table of weekly gross beta concentrations obtained by the M\&O contractor and the Foundation at common locations.

Weekly gross beta concentrations in Foundation samples ranged from a low of $(1 \pm 2) \times 10^{-15} \mu \mathrm{Ci} / \mathrm{mL}$ during December at Atomic City to a high of $(49 \pm 3) \times 10^{-15}$ $\mu \mathrm{Ci} / \mathrm{mL}$ again at Atomic City in October. Con- centrations measured by the $M \& O$ contractor ranged from a low of $(2 \pm 1) \times 10^{-15} \mu \mathrm{Ci} / \mathrm{mL}$ at TRA during January to a high of (56 \pm 3$) \times 10^{-}$ ${ }^{15} \mu \mathrm{Ci} / \mathrm{mL}$ at INTEC during October.

Foundation annual mean gross beta concentrations ranged from $(18 \pm 2) \times 10^{-15}$ $\mu \mathrm{Ci} / \mathrm{mL}$ at Craters of the Moon to $(25 \pm 2) \times$ $10^{-15} \mu \mathrm{Ci} / \mathrm{mL}$ at Mud Lake and the INEEL Main Gate (Table 4-2). M\&O contractor data indicated a range of $(11 \pm 2) \times 10^{-15} \mu \mathrm{Ci} / \mathrm{mL}$ at Blackfoot to $(24 \pm 2) \times 10^{-15} \mu \mathrm{Ci} / \mathrm{mL}$ at ARA (Table 4-2).

Figure 4-1 displays the average weekly gross beta concentrations for the INEEL, boundary, and distant station groups. These data are typical of the annual pattern for gross beta concentrations in air, with higher values generally occurring at the beginning and end of the calendar year during winter inversion conditions.

In general, the levels of airborne radioactivity for the three groups track each other closely throughout the year. This is an indication that the pattern of fluctuations occurred over the entire sampling network, and therefore were not caused by a localized source such as a facility or activity at the INEEL.

\section{Statistical Comparisons}

Statistical comparisons were made between monthly mean gross beta concentrations from each onsite and boundary location and the distant group mean gross beta concentrations. In Foundation data, INEEL station concentrations were significantly higher than the distant stations in five of 36 (14 per cent) comparisons, and boundary station concentrations were significantly higher than distant locations in 13 of 84 ( 13 per cent) comparisons (Table 4-3). For M\&O contractor samplers, INEEL concentrations were significantly higher than distant stations in six of 144 (four per cent) comparisons. Comparisons were also 
Table 4-1. Gross Alpha Activity in Air (1998)

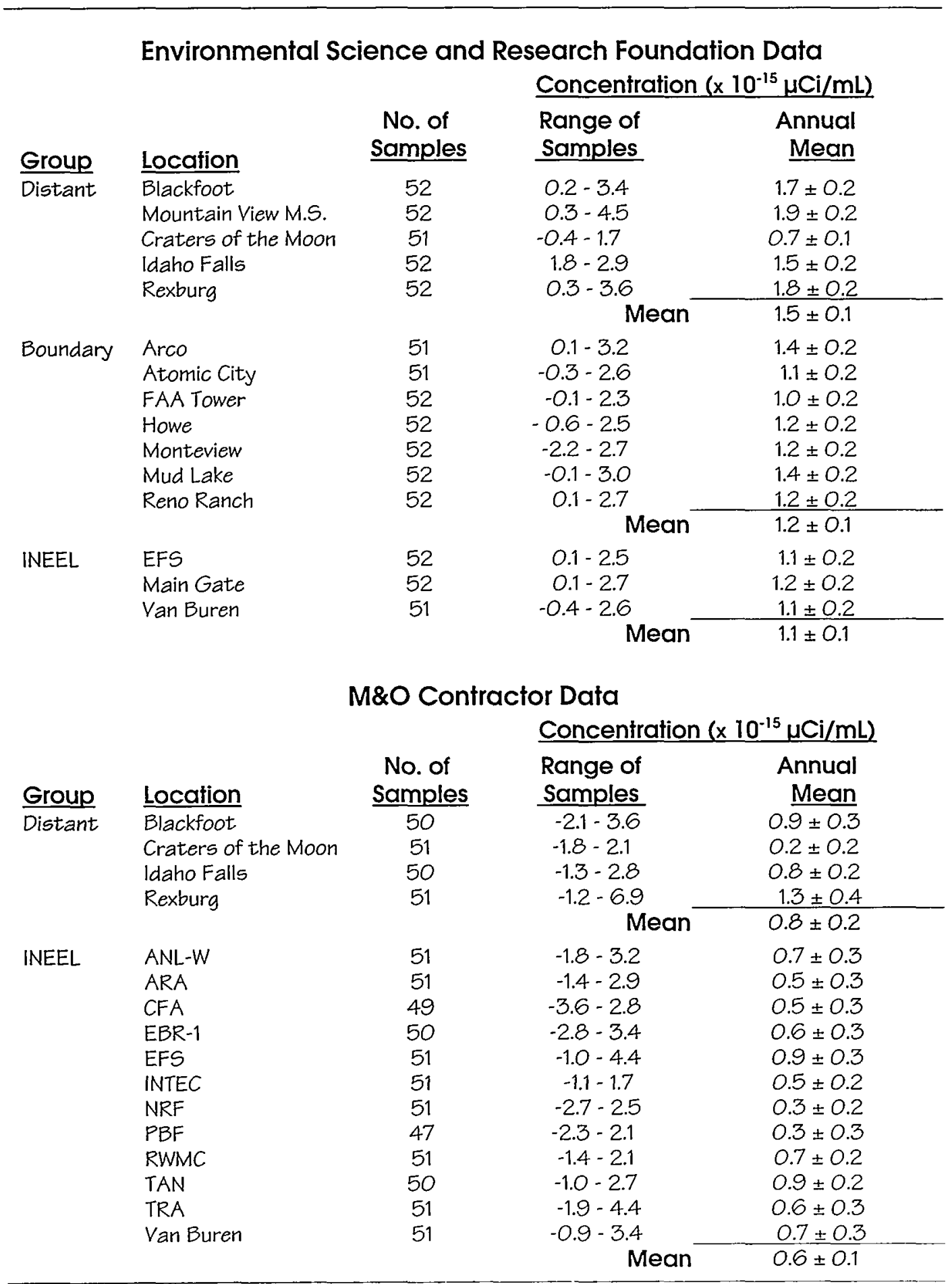


Table 4-2. Gross Beta Activity in Air (1998)

\begin{tabular}{|c|c|c|c|c|}
\hline \multicolumn{5}{|c|}{ Environmental Science and Research Foundation Data } \\
\hline \multirow[b]{2}{*}{ Group } & \multirow[b]{2}{*}{ Location } & \multirow[b]{2}{*}{$\begin{array}{c}\text { No. of } \\
\text { Samples }\end{array}$} & \multicolumn{2}{|c|}{ Concentration $\left(\times 10^{-15} \mu \mathrm{Ci} / \mathrm{mL}\right)$} \\
\hline & & & $\begin{array}{l}\text { Range of } \\
\text { Samples } \\
\end{array}$ & $\begin{array}{l}\text { Annual } \\
\text { Mean }\end{array}$ \\
\hline \multirow[t]{6}{*}{ Distant } & Blackfoot & 52 & $8-38$ & $21 \pm 2$ \\
\hline & Mountain View M.S. & 52 & $6-47$ & $21 \pm 3$ \\
\hline & Craters of the Moon & 51 & $27-41$ & $18 \pm 2$ \\
\hline & Idaho Falls & 52 & $7-44$ & $23 \pm 3$ \\
\hline & Rexburg & 52 & $8-46$ & $23 \pm 3$ \\
\hline & & & Grand Mean & $21 \pm 1$ \\
\hline \multirow[t]{8}{*}{ Boundary } & Arco & 51 & $10-43$ & $22 \pm 2$ \\
\hline & Atomic City & 51 & $1-49$ & $19 \pm 3$ \\
\hline & FAA Tower & 52 & $7-43$ & $19 \pm 2$ \\
\hline & Howe & 52 & $8-48$ & $23 \pm 2$ \\
\hline & Monteview & 52 & $9-42$ & $24 \pm 2$ \\
\hline & Mud Lake & 52 & $10-48$ & $25 \pm 2$ \\
\hline & Reno Ranch & 52 & $9-45$ & $23 \pm 2$ \\
\hline & & & Grand Mean & $23 \pm 1$ \\
\hline \multirow[t]{4}{*}{ INEEL } & EFS & 52 & $9-48$ & $24 \pm 2$ \\
\hline & Main Gate & 52 & $8-45$ & $25 \pm 2$ \\
\hline & Van Buren & 51 & $9-45$ & $24 \pm 3$ \\
\hline & & & Grand Mean & $24 \pm 1$ \\
\hline \multicolumn{5}{|c|}{ M\&O Contractor Data } \\
\hline & & & \multicolumn{2}{|c|}{ Concentration $\left(\times 10^{-15} \mu \mathrm{Ci} / \mathrm{mL}\right.$ ) } \\
\hline Group & Location & $\begin{array}{l}\text { No. of } \\
\text { Samples }\end{array}$ & $\begin{array}{l}\text { Range of } \\
\text { Samples } \\
\end{array}$ & $\begin{array}{l}\text { Annual } \\
\text { Mean }\end{array}$ \\
\hline \multirow[t]{5}{*}{$\overline{\text { Distant }}$} & $\overline{\text { Blackfoot }}$ & 50 & $6-41$ & $\overline{11 \pm 2}$ \\
\hline & Craters of the Moon & 51 & $7-37$ & $17 \pm 2$ \\
\hline & Idaho Falls & 50 & $5-44$ & $20 \pm 3$ \\
\hline & Rexburg & 51 & $6-33$ & $17 \pm 2$ \\
\hline & & & Grand Mean & $19 \pm 1$ \\
\hline \multirow[t]{13}{*}{ INEEL } & ANL-W & 51 & $4-42$ & $21 \pm 3$ \\
\hline & ARA & 51 & $13-46$ & $24 \pm 2$ \\
\hline & CFA & 49 & $8-43$ & $21 \pm 2$ \\
\hline & EBR-1 & 50 & $10-42$ & $22 \pm 3$ \\
\hline & EFS & 51 & $6-42$ & $23 \pm 3$ \\
\hline & INTEC & 51 & $4-56$ & $21 \pm 3$ \\
\hline & NRF & 51 & $7-42$ & $22 \pm 3$ \\
\hline & PBF & 47 & $5-42$ & $21 \pm 3$ \\
\hline & RWMC & 51 & $6-32$ & $19 \pm 2$ \\
\hline & TAN & 50 & $7-38$ & $20 \pm 2$ \\
\hline & TRA & 51 & $2-52$ & $23 \pm 3$ \\
\hline & Van Buren & 51 & $7-45$ & $20 \pm 3$ \\
\hline & & & Grand Mean & $21 \pm 1$ \\
\hline
\end{tabular}




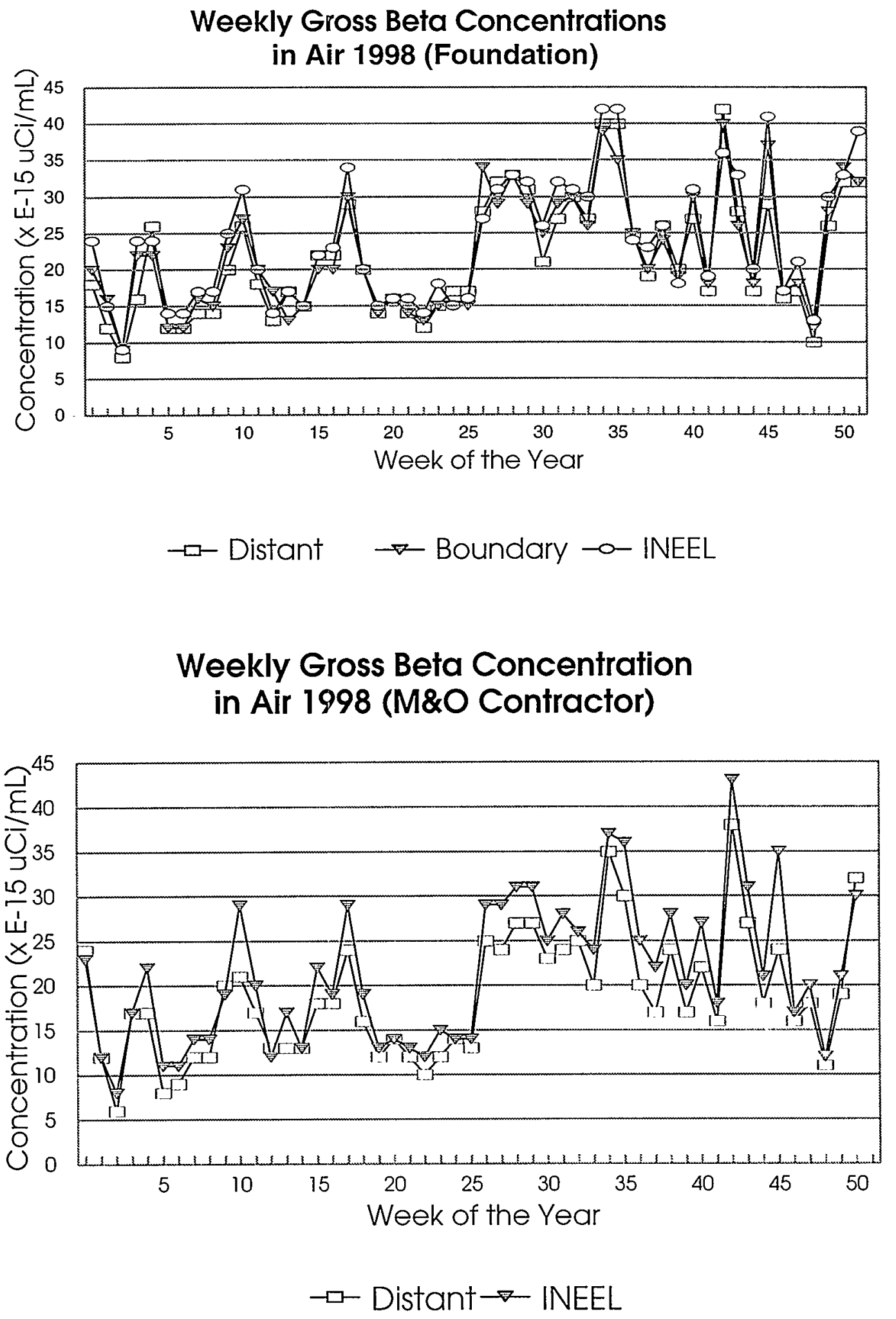

Figure 4-1. Weekly Gross Beta Concentrations in Air (1998) 
made between the mean gross beta concentration of the boundary group or onsite group and the distant group mean gross beta concentration for each month. For Foundation data, the INEEL group was statistically higher than the distant group during January, March, August, November, and December. The boundary group was statistically higher than the distant group during January. For M\&O contractor data, INEEL group gross beta concentrations were not statistically greater than the distant group in any month.

Statistical comparisons were made between annual gross beta mean concentrations at individual onsite and boundary locations and the mean annual distant station gross beta concentration (Table 4-3). For the Foundation, no annual gross beta concentrations for individual stations were statistically greater than the distant mean annual gross beta concentration. For the M\&O contractor also, no mean annual gross beta concentrations at individual stations were statistically greater than the distant mean annual gross beta concentration.

Results of the above statistical tests may indicate some of the significant differences are due to INEEL operations at the onsite locations. However, gross beta concentrations can vary widely from location to location as a result of a number of factors such as diverse local soil and meteorological conditions. Thus, when statistical differences are found, nuclide analyses discussed in the following section are examined to try to pinpoint the possible specific radionuclide(s) that may have contributed to the elevated concentrations, and to identify a possible INEEL cause, if any, for the differences.

\section{Specific Radionuclides in Air Samples}

Anthropogenic radionuclides were observed in Foundation data (Table 4-4), although most were in the range of concentrations where detection is considered questionable (see Appendix B).
Since mid-1995, ${ }^{241} \mathrm{Am}$ has been detected by the Foundation in air samples. No particular location has exhibited ${ }^{241} \mathrm{Am}$ concentrations; detections were scattered across the network. A laboratory oversight was found to be the cause of these detections. The Foundation has instituted a corrective action with the laboratory and detections of ${ }^{241} \mathrm{Am}$ have returned to expected frequency. Positive detections of specific human-made radionuclides reported by the M\&O contractor can also be found in Table 4-4.

\section{Atmospheric Moisture}

During 1998, 31 atmospheric moisture samples were collected by the Foundation from Atomic City, Blackfoot, Idaho Falls, and Rexburg. Tritium was detected in five of the samples. During the first quarter, Rexburg, Blackfoot and Idaho Falls samples displayed tritium concentrations of $(3.3 \pm 2.0) \times 10^{-15}$ $\mu \mathrm{Ci} / \mathrm{mL}$ in air, $(4.9 \pm 2.0) \times 10^{-15} \mu \mathrm{Ci} / \mathrm{mL}$ in air, and $(4.6 \pm 2.0) \times 10^{-15} \mu \mathrm{Ci} / \mathrm{mL}$ in air, respectively. Samples from Atomic City, Idaho Falls, and Rexburg had measurable concentrations of $(1.6 \pm 0.4) \times 10^{-15} \mu \mathrm{Ci} / \mathrm{mL}$, $(1.4 \pm 0.4) \times 10^{-15} \mu \mathrm{Ci} / \mathrm{mL}$, and $(1.9 \pm 0.4)$ $\times 10^{-15} \mu \mathrm{Ci} / \mathrm{mL}$ in the second quarter. No samples contained tritium during the third quarter. Idaho Falls had a measurable tritium concentration of $(4.6 \pm 2.0) \times 10^{-15} \mu \mathrm{Ci} / \mathrm{mL}$ in the fourth quarter. These detected concentrations were all very low, and concentrations were similar at distant, boundary, and onsite locations. They are probably attributable to natural production of tritium in the atmosphere by cosmic ray bombardment, from residual weapons testing fallout, and possible analytical variations, rather than to INEEL operations. The highest observed concentration (from Idaho Falls) represents approximately 0.008 per cent of the derived concentration guide.

The M\&O contractor also collected atmospheric moisture samples at the EFS and at Van Buren on the INEEL. At each location the M\&O contractor collected from one to three 


\section{Table 4-3. Statistical Comparison of Gross Beta Concentrations} in Air at Distant, Boundary and INEEL Locations (1998)

\begin{tabular}{|c|c|c|c|c|c|c|c|c|c|c|c|c|c|}
\hline \multicolumn{14}{|c|}{ Environmental Science and Research Foundation Data } \\
\hline Location & Jan & $\mathrm{Feb}$ & Mar & Apr & May & Jun & Jul & Aug & Sep & Oct & Nov & $\mathrm{Dec}$ & Year \\
\hline Arco & & $\checkmark$ & & & & & & & & & & & \\
\hline \multicolumn{14}{|l|}{ Atomic City } \\
\hline \multicolumn{14}{|l|}{ FAA Tower } \\
\hline Howe & & & & & & & & & & & $\checkmark$ & $V$ & \\
\hline Monteview & $\checkmark$ & $\checkmark$ & & & & & & & & & $\checkmark$ & & \\
\hline Mud Lake & $\checkmark$ & $\checkmark$ & & & & & & & & & $\checkmark$ & $\checkmark$ & \\
\hline Reno Ranch & $\checkmark$ & & & & & & & & & & & & \\
\hline Boundary & $\checkmark$ & & & & & & & & & & & & \\
\hline EFS & $\checkmark$ & & & & & & & & & & $\checkmark$ & & \\
\hline Main Gate & $\checkmark$ & & & & & & & & & & $\checkmark$ & $\checkmark$ & \\
\hline \multicolumn{14}{|l|}{ Van Buren } \\
\hline INEEL & $\checkmark$ & & $\checkmark$ & & & & & $\checkmark$ & & & $\checkmark$ & $\checkmark$ & \\
\hline \multicolumn{14}{|c|}{ M\&O Confractor Data } \\
\hline Location & Jan & Feb & Mar & Apr & May & Jun & Jul & Aug & Sep & Oct & Nov & Dec & Year \\
\hline \multicolumn{14}{|l|}{ ANL-W } \\
\hline ARA & $\checkmark$ & $\checkmark$ & $\checkmark$ & & & & & & & & & & \\
\hline \multicolumn{14}{|l|}{ CFA } \\
\hline EBR-1 & & & & & & & & & $\checkmark$ & & & & \\
\hline EFS & & & & & & & $\checkmark$ & & & & & & \\
\hline \multicolumn{14}{|l|}{ INTEC } \\
\hline \multicolumn{14}{|l|}{ NRF } \\
\hline \multicolumn{14}{|l|}{ PBF } \\
\hline \multicolumn{14}{|l|}{ RWMC } \\
\hline \multicolumn{14}{|l|}{ TAN } \\
\hline \multicolumn{14}{|l|}{ TRA } \\
\hline Van Buren & & & & & & & & & $\checkmark$ & & & & \\
\hline INEEL & & & & & & & & & & & & & \\
\hline
\end{tabular}

A check mark $(\checkmark)$ indicates the mean gross beta concentration for that location was statistically greater than the mean gross beta concentration for the distant group for the given time period. A single-tailed t-test $(\alpha=0.05)$ was used. 
Table 4-4. Manmade Radionuclides in Foundation and M\&O Contractor Air Samples (1998)

\begin{tabular}{|c|c|c|}
\hline \multicolumn{3}{|c|}{ Environmental Science and Research Foundation } \\
\hline Location & ${ }^{241} \mathrm{Am}\left(\times 10^{-18} \mu \mathrm{Ci} / \mathrm{mL}\right)$ & ${ }^{90} \mathrm{Sr}\left(\times 10^{-11} \mathrm{pCi} / \mathrm{mL}\right)$ \\
\hline \multicolumn{3}{|c|}{ First Quarter 1998} \\
\hline Blackfoot & $1.9 \pm 1.5$ & No Detections \\
\hline Arco & $2.1 \pm 1.5$ & No Detections \\
\hline \multicolumn{3}{|c|}{ Second Quarter 1998} \\
\hline \multicolumn{3}{|c|}{ No Detections } \\
\hline \multicolumn{3}{|c|}{ Third Quarter 1998} \\
\hline \multicolumn{3}{|c|}{ No Detections } \\
\hline \multicolumn{3}{|c|}{ Fourth Quarter 1998} \\
\hline \multicolumn{3}{|c|}{ No Detections } \\
\hline \multicolumn{3}{|c|}{ M\&O Contractor } \\
\hline \multirow[t]{3}{*}{ Location } & ${ }^{241} \mathrm{Am}\left(\times 10^{-18} \mu \mathrm{Ci} / \mathrm{mL}\right)$ & ${ }^{90} \mathrm{Sr}\left(\times 10^{-11} \mathrm{pCi} / \mathrm{mL}\right)$ \\
\hline & \multicolumn{2}{|c|}{$\begin{array}{l}\text { First Quarter } 1998 \\
\text { No Detections }\end{array}$} \\
\hline & \multicolumn{2}{|c|}{ Second Quarter 1998} \\
\hline NRF & No Detections & $9.7 \pm 6.4$ \\
\hline TRA & No Detections & $9.0 \pm 6.0$ \\
\hline \multirow[t]{2}{*}{ INTEC } & No Detections & $6.6 \pm 5.0$ \\
\hline & \multicolumn{2}{|c|}{ Third Quarter 1998} \\
\hline Rexburg & No Detections & $7.4 \pm 6.4$ \\
\hline Blackfoot & No Detections & $13 \pm 8.5$ \\
\hline lodaho Falls & No Detections & $11 \pm 6.8$ \\
\hline NRF & No Detections & $7.1 \pm 6.5$ \\
\hline EFS & No Detections & $11 \pm 63$ \\
\hline TRA & No Detections & $16 \pm 7.7$ \\
\hline INTEC & No Detections & $11 \pm 5.3$ \\
\hline CFA & No Detections & $9.6 \pm 6.3$ \\
\hline \multirow[t]{2}{*}{ ANL-W } & $10 \pm 5.7$ & No Detections \\
\hline & \multicolumn{2}{|c|}{$\begin{array}{c}\text { Fourth Quarter } 1998 \\
\text { No Detections }\end{array}$} \\
\hline
\end{tabular}


samples each quarter. Preliminary laboratory analyses indicated that some samples may have contained detectable concentrations of tritium, but contamination was also discovered in the laboratory.

\section{Precipitation}

When precipitation occurred, the Foundation collected precipitation samples weekly onsite at the EFS and monthly onsite at the CFA and offsite in Idaho Falls. A total of 49 precipitation samples were collected during 1998. Tritium was detected in four of the samples at concentrations ranging from (1.2 \pm

1.0) $\times 10^{-7} \mu \mathrm{Ci} / \mathrm{mL}$ to $(4.9 \pm 1.1) \times 10^{-7}$ $\mu \mathrm{Ci} / \mathrm{mL}$. The highest concentration was from EFS. The concentrations are well within the normal range observed worldwide in recent years and are likely due to the worldwide inventory of tritium from natural production of tritium in the upper atmosphere and also to expected variability in laboratory analyses.

\subsection{WATER}

This section presents results from radiological analyses performed on drinking water and surface water samples taken at offsite locations by the Environmental Science and Research Foundation. In addition, the M\&O contractor's storm water monitoring results are presented. Radiological results from onsite production well sampling may be found in Chapter 6, "Ground Water," together with with results from additional sampling conducted by the M\&O contractor Drinking Water Program.

\section{Offsite Water Sampling}

Gross Alpha. In 1998, the Foundation collected 36 offsite water samples, eight from surface water locations and 28 from drinking water locations. No samples contained detectable concentrations of gross alpha.

Gross Beta. Gross beta activity above the minimum detectable concentration was present in 32 of the 36 offsite water samples. Detectable concentrations ranged from $(3.0 \pm 2.0)$ $\mathrm{pCi} / \mathrm{L}$ to $(8.0 \pm 3.0) \mathrm{pCi} / \mathrm{L}$. The upper value of this range is 16 per cent of the EPA Maximum Contaminant Level for drinking water. Concentrations in this range are normal and are attributed to natural decay processes of thorium and uranium which is sorbed into the water as it passes through the earth's crust.

Tritium. Tritium was not detected in offsite drinking water samples.

\section{Storm Water Sampling}

During 1998, 15 storm water samples were analyzed for gross alpha, gross beta, ${ }^{89 / 90} \mathrm{Sr}$, ${ }^{234} \mathrm{U},{ }^{241} \mathrm{Am}$, and ${ }^{239} \mathrm{Pu}$. Benchmarks have been established for radionuclides in storm water runoff at the INEEL, based on the Derived Concentration Guides in DOE Order 5400.5. One sample from INTEC had a measurable gross alpha activity of $(3.4 \pm 1.2 \mathrm{pCl} / \mathrm{L})$. Gross beta activity was found in samples from INTEC (13.5 $\pm 1.7 \mathrm{pCl} / \mathrm{L}), \operatorname{PBF}(5.0 \pm 2 \mathrm{pCl} / \mathrm{L})$, and two samples from SMC $(9.6 \pm 1.5$ and $13.4 \pm 3.5 \mathrm{pCl} / \mathrm{L})$. One sample from SMC had both ${ }^{239} \mathrm{Pu}$ and ${ }^{234} \mathrm{U}$ at concentrations of $0.04 \pm 0.03 \mathrm{pCl} / \mathrm{L}$ and $0.39 \pm 0.08 \mathrm{pCl} / \mathrm{L}$, respectively.

More detailed information and data on storm water monitoring was included in the 1998 Compliance Monitoring Annual Report, INEEL-99/0255(99) (published in August 1999).

\subsection{FOODSTUFFS}

Milk. During 1998, 152 milk samples were collected. All of the samples were analyzed for ${ }^{131}$ I. During the first and third quarters, selected samples were analyzed for tritium. During the second and fourth quarters, selected samples were analyzed for ${ }^{90} \mathrm{Sr}$.

No ${ }^{131}$ I was detected in any milk samples. Tritium was not detected in any 1998 milk samples. Strontium-90 was detected in seven 
samples ranging from $(3.1 \pm 2.6) \times 10^{-4}$ $\mathrm{pCi} / \mathrm{mL}$ at Howe to $(6.8 \pm 3.3) \times 10^{-4} \mathrm{pCi} / \mathrm{mL}$ in a sample from Dietrich. All levels of ${ }^{90} \mathrm{Sr}$ in milk were consistent with those previously reported by the EPA as resulting from worldwide fallout deposited on soil, then taken up by ingestion of grass by cows [Reference 4-1].

Lettuce. Nine lettuce samples, including one duplicate, were collected from regional private gardens. Cesium-137 was detected in a sample from Howe at a concentration of $(6.0 \pm 4.2) \times 10^{-7} \mu \mathrm{Ci} / \mathrm{g}$. Strontium-90 was detected in all nine of the lettuce samples (Table 4-5). Both ${ }^{137} \mathrm{Cs}$ and ${ }^{90} \mathrm{Sr}$ are present in soil from above-ground nuclear weapons testing which took place between 1945 and 1980 .

Wheat. Of the 11 wheat samples collected during 1998 , one sample from Taber contained
${ }^{137} \mathrm{Cs}$ at a concentration of $(3.3 \pm 2.5) \times 10^{-9}$ $\mu \mathrm{Ci} / g$. However, this value is barely in the detectable range and may be due to normal statistical fluctuations in radiometric analysis. Measurable concentrations of ${ }^{90} \mathrm{Sr}$ were seen in 10 samples from both distant and boundary locations (Table 4-6). The concentrations of ${ }^{90} \mathrm{Sr}$ were similar to those detected in recent years, and are attributed to historic aboveground nuclear weapons testing (1945 1980).

Potatoes. Seven potato samples were collected during 1998, four from distant locations and three from boundary locations. Strontium90 was detected in the sample from Monteview at a concentration of $(5.8 \pm 5.1) \times 10^{-3} \mathrm{pCi} / \mathrm{g}$, a sample from Blackfoot at $(3.2 \pm 2.6) \times 10^{-3}$

Table 4-5. Strontium-90 Concentrations in Garden Lettuce (1994-1998)

\begin{tabular}{|c|c|c|c|c|c|c|}
\hline \multirow[b]{2}{*}{ Location } & & \multicolumn{5}{|c|}{ Strontium-90 Concentration $\left(10^{-9} \mu \mathrm{Ci} / \mathrm{g}\right.$ dry weight) } \\
\hline & & 1994 & 1995 & 1996 & 1997 & 1998 \\
\hline \multicolumn{7}{|c|}{ Distant Group } \\
\hline Blackfoot & & $160 \pm 80^{\circ}$ & $740 \pm 200$ & $270 \pm 240$ & $90 \pm 70$ & $100 \pm 80$ \\
\hline Carey & & $130 \pm 40$ & $-50 \pm 180$ & NS $^{b}$ & $70 \pm 50$ & $200 \pm 50$ \\
\hline \multirow[t]{2}{*}{ Idaho Falls } & & $120 \pm 40$ & $60 \pm 30$ & NS & $50 \pm 30$ & $200 \pm 30$ \\
\hline & Mean & $140 \pm 50$ & $140 \pm 50$ & $270 \pm 240$ & $60 \pm 40$ & $167 \pm 50$ \\
\hline \multicolumn{7}{|c|}{ Boundary Group } \\
\hline Arco & & $50 \pm 40$ & $140 \pm 50$ & $200 \pm 200$ & $70 \pm 70$ & $200 \pm 100$ \\
\hline Atomic City & & $200 \pm 60$ & $300 \pm 120$ & $120 \pm 100$ & $160 \pm 60$ & $100 \pm 70$ \\
\hline Howe & & NS & NS & $100 \pm 160$ & $80 \pm 80$ & $100 \pm 90$ \\
\hline Monteview & & $110 \pm 40$ & $100 \pm 90$ & NS & $90 \pm 40$ & $100 \pm 50$ \\
\hline \multirow[t]{2}{*}{ Mud Lake } & & $70 \pm 60$ & $80 \pm 40$ & $160 \pm 360$ & $170 \pm 80$ & $100 \pm 80$ \\
\hline & Mean & $110 \pm 100$ & $160 \pm 160$ & $140 \pm 70$ & $130 \pm 60$ & $120 \pm 80$ \\
\hline
\end{tabular}


Table 4-6. Strontium-90 Concentrations in Wheat (1994-1998)

\begin{tabular}{|c|c|c|c|c|c|c|}
\hline \multirow[b]{2}{*}{ Location } & & \multicolumn{5}{|c|}{ Strontium-90 Concentration $\left(10^{-9} \mu \mathrm{Ci} / \mathrm{g}\right.$ dry weight) } \\
\hline & & 1994 & 1995 & 1996 & 1997 & 1998 \\
\hline \multicolumn{7}{|c|}{ Distant Group } \\
\hline \multicolumn{2}{|c|}{ American Falls } & $7 \pm 2^{a}$ & $8 \pm 4$ & $7 \pm 5$ & $9 \pm 5$ & $6 \pm 4$ \\
\hline \multicolumn{2}{|l|}{ Blackfoot } & $7 \pm 2$ & $4 \pm 4$ & $6 \pm 6$ & $14 \pm 6$ & $8 \pm 4$ \\
\hline \multicolumn{2}{|l|}{ Carey } & $2 \pm 2$ & $11 \pm 7$ & $5 \pm 6$ & $5 \pm 4$ & NS \\
\hline \multicolumn{2}{|l|}{ Dietrich } & $3 \pm 2$ & NS & $5 \pm 5$ & $4 \pm 4$ & $4 \pm 3$ \\
\hline \multicolumn{2}{|l|}{ Idaho Falls } & $6 \pm 2$ & $9 \pm 5$ & $9 \pm 18$ & $4 \pm 4$ & $7 \pm 3$ \\
\hline \multirow[t]{2}{*}{ Minidoka } & & $6 \pm 2$ & $3 \pm 5$ & $8 \pm 5$ & $5 \pm 4$ & $6 \pm 3$ \\
\hline & Mean & $5 \pm 2$ & $7 \pm 4$ & $7 \pm 2$ & $7 \pm 4$ & $6 \pm 3$ \\
\hline \multicolumn{7}{|c|}{ Boundary Group } \\
\hline \multicolumn{2}{|c|}{ Arco } & $4 \pm 2$ & $3 \pm 5$ & $16 \pm 40$ & $4 \pm 3$ & $6 \pm 3$ \\
\hline \multicolumn{2}{|l|}{ Monteview } & $7 \pm 3$ & $4 \pm 4$ & $3 \pm 4$ & $5 \pm 5$ & $9 \pm 4$ \\
\hline \multicolumn{2}{|l|}{ Mud Lake } & $5 \pm 2$ & $4 \pm 5$ & $5 \pm 5$ & $4 \pm 4$ & $8 \pm 4$ \\
\hline \multicolumn{2}{|l|}{ Taber } & $8 \pm 2$ & $12 \pm 6$ & $10 \pm 6$ & $5 \pm 5$ & $6 \pm 3$ \\
\hline \multirow[t]{2}{*}{ Terreton } & & $5 \pm 2$ & $7 \pm 5$ & $8 \pm 6$ & $6 \pm 4$ & $7 \pm 3$ \\
\hline & Mean & $6 \pm 2$ & $6 \pm 5$ & $8 \pm 6$ & $5 \pm 1$ & $7 \pm 3$ \\
\hline
\end{tabular}

$\mathrm{pCi} / \mathrm{g}$, and in a sample from Arco at a concentration of $(5.4 \pm 3.6) \times 10^{-3} \mathrm{pCi} / \mathrm{g}$. These concentrations are consistent with past results seen in potatoes, wheat, and lettuce and are likely due to historic worldwide fallout from nuclear weapons testing and the Chernobyl reactor accident in 1986.

Sheep. Six sheep were sampled during the second quarter of 1998. Four were taken from INEEL land, and two were taken from Blackfoot to serve as control samples. Cesium-137 was detected in the muscle tissue of one of the control samples at $(4.0 \pm 3.2) \times 10^{-9} \mu \mathrm{Ci} / \mathrm{g}$. Cesium-137 was also found in three of the four onsite samples ranging from $(4.1 \pm 3.4) \times 10^{-9}$ $\mu \mathrm{Ci} / \mathrm{g}$ to $(7.0 \pm 3.5) \times 10^{-9} \mu \mathrm{Ci} / \mathrm{g}$. It was also detected in livers of two samples at concentrations of $(6.4 \pm 3.9)$ and $(4.0 \pm 3.4) \times 10^{-9}$ $\mu \mathrm{Ci} / \mathrm{g}$. All ${ }^{137} \mathrm{Cs}$ concentrations were similar to those found in both onsite and offsite sheep samples during recent years. lodine-131 was not detected in any of the sheep.

Game Animals. Seven mule deer, three pronghorns, and two elk which had been accidentally killed on INEEL roads, were sampled. One pronghorn, one elk, and five mule deer, one of which was collected $23 \mathrm{~km}$ to the west of the INEEL and can be considered a control, had small cesium-137 activities in their muscle samples. Concentrations in these samples ranged from $(2.3 \pm 2.1) \times 10^{-9} \mu \mathrm{Ci} / g$ to $(16.9$ $\pm 2.6) \times 10^{-9} \mu \mathrm{Ci} / g$. There was also detectable cesium-137 activity in the liver of one mule deer $\left[(13.3 \pm 4.5) \times 10^{-9} \mu \mathrm{Ci} / \mathrm{g}\right]$ and one pronghorn $\left[(6.6 \pm 5.8) \times 10^{-9} \mu \mathrm{Ci} / \mathrm{g}\right]$. All of these low activities are within the range of historical values and can be attributed to the ingestion of radionuclides from worldwide fallout from above ground nuclear weapons 
testing. No ${ }^{131} \mid$ was detected in any of the thyroid glands.

A total of nine mourning doves were collected: five from TRA and four from INTEC. Due to the small sample size of muscle tissue from an individual dove, all doves from each location were composited into one sample. Samples were analyzed for gamma emitting radionuclides, ${ }^{90} \mathrm{Sr},{ }^{238} \mathrm{Pu},{ }^{239 / 240} \mathrm{Pu}$, and ${ }^{241} \mathrm{Am}$. A total of four human-made radionuclides were detected in dove muscle samples, one $\left({ }^{54} \mathrm{Mn}\right)$ in the TRA doves sample and three $\left({ }^{60} \mathrm{Co},{ }^{137} \mathrm{Cs}\right.$, and ${ }^{141} \mathrm{Ce}$ ) in the INTEC doves (Table 4-7).

During 1998 a total of 12 ducks were collected: four from ANL-W, two from TRA, one from INTEC, and five controls from Ft. Hall. All were analyzed for gamma emitting radionuclides with one randomly selected sample from each location analyzed for ${ }^{90} \mathrm{Sr},{ }^{238} \mathrm{Pu}$, ${ }^{239 / 240} \mathrm{Pu}$, and ${ }^{240} \mathrm{Am}$. A total of nine humanmade radionuclides were detected in those samples with the most (5) found in the duck taken from INTEC (Table 4-8).

Also during 1998 a total of nine yellowbellied marmots were collected: six from the RWMC and three controls ( $43 \mathrm{~km}$ southeast of the INEEL). All were analyzed for gamma emitting radionuclides with one randomly selected control sample and three randomly selected RWMC samples analyzed for ${ }^{90} \mathrm{Sr}$, ${ }^{238} \mathrm{Pu},{ }^{239 / 240} \mathrm{Pu}$, and ${ }^{241} \mathrm{Am}$. A total of nine human-made radionuclides were detected in those samples with eight found in marmots taken from the RWMC (Table 4-9). Calculated hypothetical doses to humans from marmot consumption can be found in Chapter 8 , Dose to the Public.

\subsection{SOIL}

Biennial soil sampling was conducted during 1998. Soil samples from 12 different offsite locations were sampled at two depths: $0-5 \mathrm{~cm}$ (0-2 inches) and $5-10 \mathrm{~cm} \mathrm{(2-4}$ inches). The surface soils $(0-5 \mathrm{~cm})$ were analyzed for gamma-emitting radionuclides, ${ }^{90} \mathrm{Sr}$, and selected alpha-emitting transuranics (Figure 4-2). Data for the 5-10 cm depth samples are not presented because most of the measured activity was found in the upper depth layer. The data are reported in units of areal activity $\left(\mathrm{nCi} / \mathrm{m}^{2}\right)$. The human-made radionuclides detected were present as a result of worldwide fallout from atmospheric testing of

\section{Table 4-7. Human-made Radionuclides Detected in Breast Meat of Mourning Doves Collected on the INEEL (1998)}

\begin{tabular}{|c|c|c|}
\hline Location & Radionuclide $^{a}$ & Concentration $\left(\times 10^{-6} \mu \mathrm{Ci} / 9\right)$ \\
\hline \multirow[t]{2}{*}{$\begin{array}{c}\text { TRA } \\
\text { (composite of } 5 \text { doves) }\end{array}$} & ${ }^{54} \mathrm{Mn}$ & $0.054 \pm 0.040^{b}$ \\
\hline & ${ }^{60} \mathrm{Co}$ & $0.055 \pm 0.040$ \\
\hline \multirow{2}{*}{$\begin{array}{c}\text { INTEC } \\
\text { (composite of } 4 \text { doves) }\end{array}$} & ${ }^{137} \mathrm{Cs}_{5}$ & $0.055 \pm 0.044$ \\
\hline & ${ }^{141} \mathrm{Ce}$ & $4.160 \pm 3.200$ \\
\hline
\end{tabular}


Table 4-8. Manmade Radionuclides Detected in Edible Portions of Waterfowl (1998) Concentration $\left(\times 10^{-6} \mu \mathrm{Ci} / \mathrm{g}\right)$

\begin{tabular}{|c|c|c|c|c|}
\hline \multirow[t]{2}{*}{ Location } & Radionuclide & $\underline{\text { Minimum }}$ & Maximum & Mean \\
\hline & ${ }^{134} \mathrm{Cs}$ & $<m d c^{a}$ & $0.005_{\frac{t}{b}} 0.004$ & $0.005 \pm 0.008^{c}$ \\
\hline \multirow[t]{3}{*}{ Control $(n=5)$} & ${ }^{137} \mathrm{Cs}$ & $<m d c$ & $0.009 \pm 0.004$ & $0.004 \pm 0.006$ \\
\hline & ${ }^{141} \mathrm{Ce}$ & $<m d c$ & $0.143 \pm 0.136$ & $0.113 \pm 0.190$ \\
\hline & ${ }^{58} \mathrm{Co}$ & $<m d c$ & $0.128 \pm 0.100$ & $0.017 \pm 0.380$ \\
\hline \multirow[t]{5}{*}{ ANL-W $(n=4)$} & ${ }^{90} \mathrm{Sr}$ & \multicolumn{2}{|c|}{$0.068 \pm 0.030$} & $N A^{d}$ \\
\hline & ${ }^{134} \mathrm{C}_{5}$ & $<m d c$ & $0.052 \pm 0.046$ & $0.007 \pm 0.142$ \\
\hline & ${ }^{137} \mathrm{Cs}$ & $<m d c$ & $0.074 \pm 0.040$ & $0.022 \pm 0.136$ \\
\hline & ${ }^{65} \mathrm{Zn}$ & 0.015 & 0.010 & NA \\
\hline & ${ }^{134} \mathrm{Cs}_{5}$ & - & $0.002 \ldots$ & NA \\
\hline \multirow[t]{4}{*}{ INTEC $(n=1)$} & ${ }^{137} \mathrm{Cs}$ & - 1.120 & 0.050 & NA \\
\hline & ${ }^{141} \mathrm{Ce}$ & 0.018 & 0.016 & NA \\
\hline & ${ }^{238} \mathrm{Pu}$ & - 0.011 & 0.004 & NA \\
\hline & ${ }^{54} \mathrm{Mn}$ & $<m d c$ & $0.005 \pm 0.004$ & $0.009 \pm 0.068$ \\
\hline \multirow[t]{3}{*}{$\operatorname{TRA}(n=2)$} & ${ }^{60} \mathrm{Co}$ & $0.096 \pm 0.006$ & $0.397 \pm 0.048$ & $0.247 \pm 0.348$ \\
\hline & ${ }^{65} \mathrm{Zn}$ & $<m d c$ & $0.591 \pm 0.032$ & $0.307 \pm 0.672$ \\
\hline & ${ }^{137} \mathrm{Cs}$ & $0.059 \pm 0.040$ & $0.492 \pm 0.024$ & $0.275 \pm 0.480$ \\
\hline \multicolumn{5}{|c|}{$\begin{array}{l}\text { a }<M D C \text { indicates less than minimum detectable concentration. } \\
\text { b Concentration } \pm 2 \text { standard deviations. } \\
\text { c Mean } \pm 2 \text { standard deviations of the mean with errors of individual estimates propagated. } \\
\text { d NA indicates not applicable. }\end{array}$} \\
\hline
\end{tabular}

nuclear weapons. The shorter-lived radionuclides $\left({ }^{90} \mathrm{Sr}\right.$ and $\left.{ }^{137} \mathrm{Cs}\right)$ continue to show a slow but steady decrease. Figure 4-2 displays specific radionuclide concentrations in offsite soils from 1975 to the present.

\subsection{ENVIRONMENTAL DOSIMETERS}

The measured cumulative radiation exposure for offsite locations for the time period from November 1997 to November 1998 is shown in Table 4-10 for the duplicate set of dosimeters maintained by the Foundation and the $M \& O$ contractor. For purposes of 

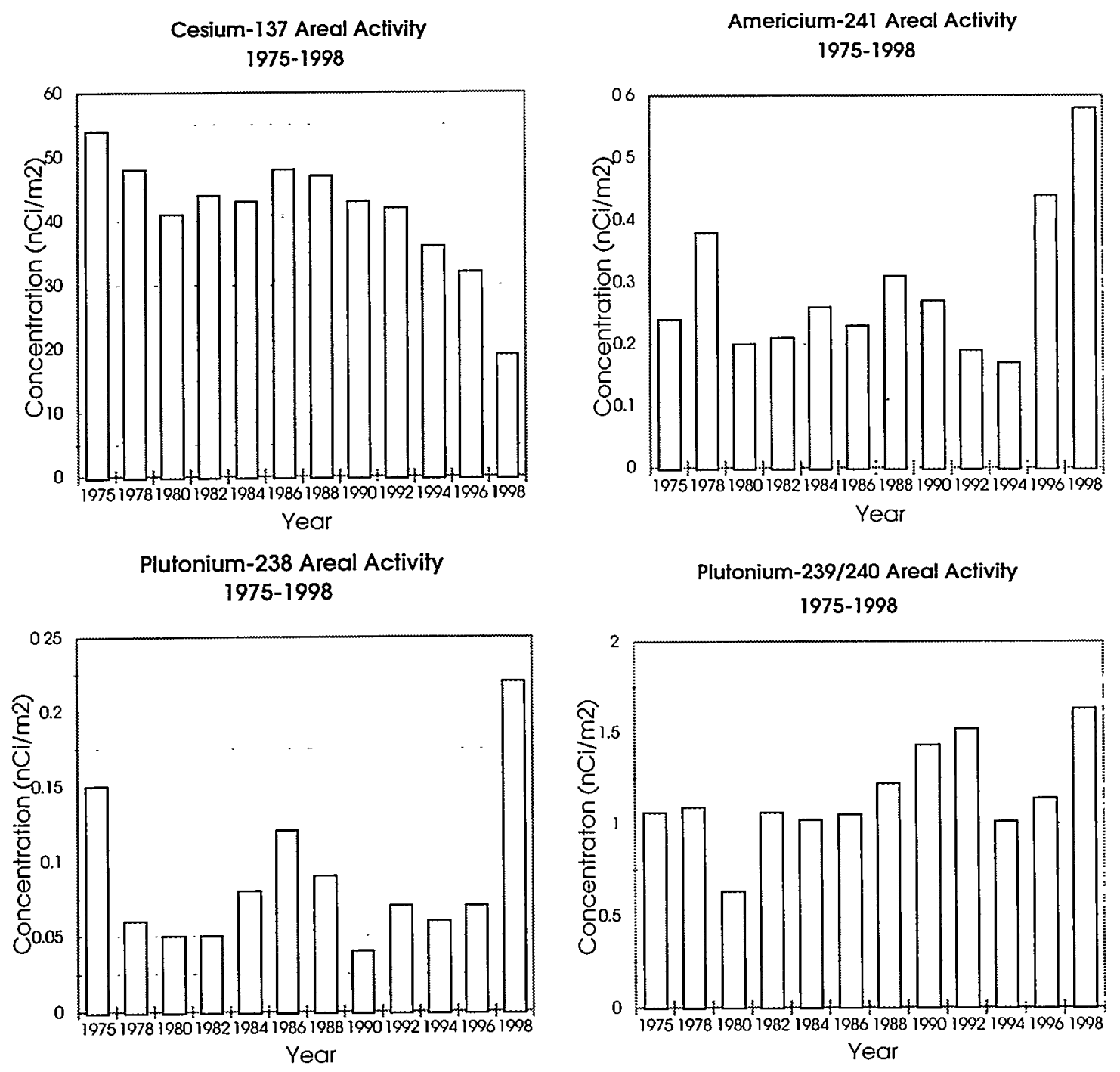

Strontium-90 Areal Activity

1975-1998

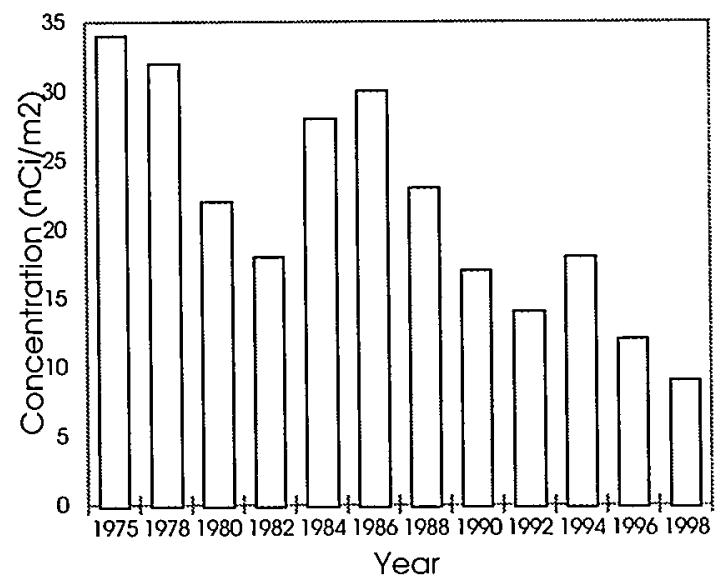

Figure 4-2. Radionuclides in Offsite Surface Soils (1975-1998) 
Table 4-10. Environmental Exposures (1995-1998)

\begin{tabular}{|c|c|c|c|c|c|c|c|c|}
\hline \multirow[b]{3}{*}{ Distant Group } & \multicolumn{8}{|c|}{ Annual Exposure (mR) } \\
\hline & \multicolumn{2}{|c|}{1995} & \multicolumn{2}{|c|}{1996} & \multicolumn{2}{|c|}{1997} & \multicolumn{2}{|c|}{1998} \\
\hline & ESRF & LMITCO & ESRF & LMITCO & ESRF & LMITCO & ESRF & LMITCO \\
\hline Aberdeen & $108 \pm 3^{\circ}$ & $110 \pm 4$ & NS ${ }^{b}$ & NS & $137 \pm 8$ & $134 \pm 4$ & $128 \pm 8$ & $157 \pm 18$ \\
\hline Blackfoot & $117 \pm 4$ & $118 \pm 4$ & $120 \pm 8$ & $132 \pm 7$ & $129 \pm 6$ & $116 \pm 4$ & $130 \pm 6$ & $134 \pm 7$ \\
\hline Blackfoot (MVMS) ${ }^{c}$ & & & & & $122 \pm 5$ & & $113 \pm 4$ & \\
\hline Craters of the Moon & $114 \pm 4$ & $109 \pm 4$ & $117 \pm 4$ & $122 \pm 6$ & $122 \pm 7$ & $119 \pm 6$ & $122 \pm 6$ & $121 \pm 8$ \\
\hline Idaho Falls & $120 \pm 5$ & $122 \pm 6$ & $120 \pm 5$ & $120 \pm 6$ & $132 \pm 7$ & $119 \pm 7$ & $124 \pm 6$ & $115 \pm 6$ \\
\hline Minidoka & $105 \pm 2$ & NS & $118 \pm 5$ & $121 \pm 4$ & $110 \pm 5$ & $113 \pm 8$ & $116 \pm 7$ & $113 \pm 6$ \\
\hline Rexburg & $109 \pm 3$ & $114 \pm 4$ & $122 \pm 4$ & $125 \pm 11$ & $144 \pm 8$ & $120 \pm 5$ & $144 \pm 7$ & $116 \pm 4$ \\
\hline Roberts & $118 \pm 5$ & $126 \pm 6$ & $140+9$ & $141 \pm 9$ & $140 \pm 11$ & $140 \pm 7$ & $130 \pm 6$ & $137 \pm 8$ \\
\hline Mean & $113 \pm 5$ & $117 \pm 7$ & $127 \pm 9$ & $130 \pm 8$ & $123 \pm 9$ & $123 \pm 9$ & $126 \pm 6$ & $128 \pm 11$ \\
\hline \multicolumn{9}{|l|}{ Boundary Group } \\
\hline Arco & $118 \pm 3$ & $121 \pm 7$ & $131 \pm 6$ & $130 \pm 4$ & $125 \pm 9$ & $125 \pm 9$ & $128 \pm 7$ & $117 \pm 6$ \\
\hline Atomic City & $124 \pm 5$ & $126 \pm 5$ & $136 \pm 6$ & $144 \pm 14$ & $134 \pm 10$ & $137 \pm 11$ & $132 \pm 6$ & $124 \pm 5$ \\
\hline Howe & $112 \pm 4$ & $108 \pm 4$ & $117 \pm 8$ & $122 \pm 6$ & $125 \pm 6$ & $122 \pm 9$ & $125 \pm 5$ & $116 \pm 7$ \\
\hline Monteview & $118 \pm 4$ & $120 \pm 6$ & $122 \pm 4$ & $108 \pm 4$ & $127 \pm 8$ & $108 \pm 4$ & $124 \pm 4$ & $113 \pm 8$ \\
\hline Mud Lake & $117 \pm 7$ & NS & $129 \pm 6$ & $139 \pm 9$ & $127 \pm 9$ & $125 \pm 9$ & $137 \pm 7$ & $130 \pm 4$ \\
\hline Reno Ranch & $113 \pm 4$ & $117 \pm 8$ & $110 \pm 4$ & $109 \pm 6$ & $126 \pm 8$ & $111 \pm 8$ & $117 \pm 6$ & $105+6$ \\
\hline Mean & $117 \pm 5$ & $118 \pm 8$ & $124 \pm 10$ & $125 \pm 16$ & $127 \pm 3$ & $121 \pm 11$ & $127 \pm 5$ & $118 \pm 6$ \\
\hline \multicolumn{9}{|c|}{$\begin{array}{l}\text { Annual Exposure } \pm 25 . \\
\text { "NS indicates dosimeter damaged or missing. } \\
\text { LMITCO does not sample at Mountain View Middle School (MVMS), established Oct. } 1996 .\end{array}$} \\
\hline
\end{tabular}

$27 \mathrm{mrem} / \mathrm{yr}$, respectively, for a total of 76 $\mathrm{mrem} / \mathrm{yr}$. Because snow cover can reduce the effective dose equivalent Idaho residents receive from the soil, a correction factor must be made each year to the above estimate of $76 \mathrm{mrem} / \mathrm{yr}$. For 1998, this resulted in 71 $\mathrm{mrem} / \mathrm{yr}$ due to snow cover, which reached a maximum depth of $23 \mathrm{~cm}$ (9 in).

The cosmic component varies primarily with altitude increasing from about 26 mrem at sea level to about 48 mrem at the elevation of the INEEL at approximately $1,500 \mathrm{~m}(4,900 \mathrm{ft})$ [Reference 4-3]. This may vary slightly due to solar cycle fluctuations and other factors.
The estimated sum of the terrestrial and cosmic components for 1998 was 119 mrem. This is about 10 per cent less than the value of 131 mrem measured at distant location by thermoluminescent dosimeters (TLDs), after conversion from $\mathrm{mR}$ to mrem in tissue.

The component of background dose that varies the most is inhaled radionuclides. According to the National Council on Radiation Protection, the major radionuclides contributing to this component are short-lived decay products of radon, and the amount of radon in buildings and ground water depends, in part, upon the natural radionuclide content of the soil and rock of the area. There is also variation between buildings of a given geographic 
area depending upon the materials each contains, the amount of ventilation and air movement, and other factors. The U.S. average of 200 mrem has been used in Table 4-11 for this component of the total background dose because no specific estimate for southeastern Idaho has been made, and few specific measurements have been made of radon in homes in this area. Therefore, the effective dose equivalent from natural background radiation for residents in the INEEL vicinity may actually be higher or lower than the total estimated background dose of about 360 mrem shown in Table 4-11 and will vary from one location to another.

Onsite TLDs representing the same exposure period as the offsite dosimeters are shown in Figures 4-3 through 4-12. The results are expressed in $\mathrm{mR} \pm 2 \mathrm{~s}$. Onsite dosimeters were placed on facility perimeters, concentrated in areas likely to show the highest gamma radiation readings. Other onsite dosimeters are located in the vicinity of radioactive materials storage areas. At some facilities slightly elevated exposures result from areas of soil contamination around the perimeter of these facilities.

Table 4-11. Estimated Natural Background Effective Dose Equivalent in mrem (1998)

\begin{tabular}{|c|c|c|}
\hline \multirow[b]{2}{*}{$\begin{array}{l}\text { Source of Radiation } \\
\text { Dose Equivalent }\end{array}$} & \multicolumn{2}{|c|}{ Total Average Annual } \\
\hline & $\begin{array}{c}\text { mrem } \\
\text { Estimated }\end{array}$ & $\begin{array}{c}\text { mrem } \\
\text { Measured }\end{array}$ \\
\hline \multicolumn{3}{|l|}{ External } \\
\hline Terrestrial & 71 & N/A \\
\hline Cosmic & $\underline{48}$ & $\underline{N / A}$ \\
\hline Subtotal & 119 & 131 \\
\hline \multicolumn{3}{|l|}{ Internal } \\
\hline Cosmogenic & 1 & \\
\hline Inhaled Radionuclides & 200 & \\
\hline${ }^{40} \mathrm{~K}$ and others & $\underline{39}$ & \\
\hline Subtotal & 240 & \\
\hline Total & - & \\
\hline & $\overline{359}$ & \\
\hline
\end{tabular}

N/A indicates radiation parameters not measured individually. 


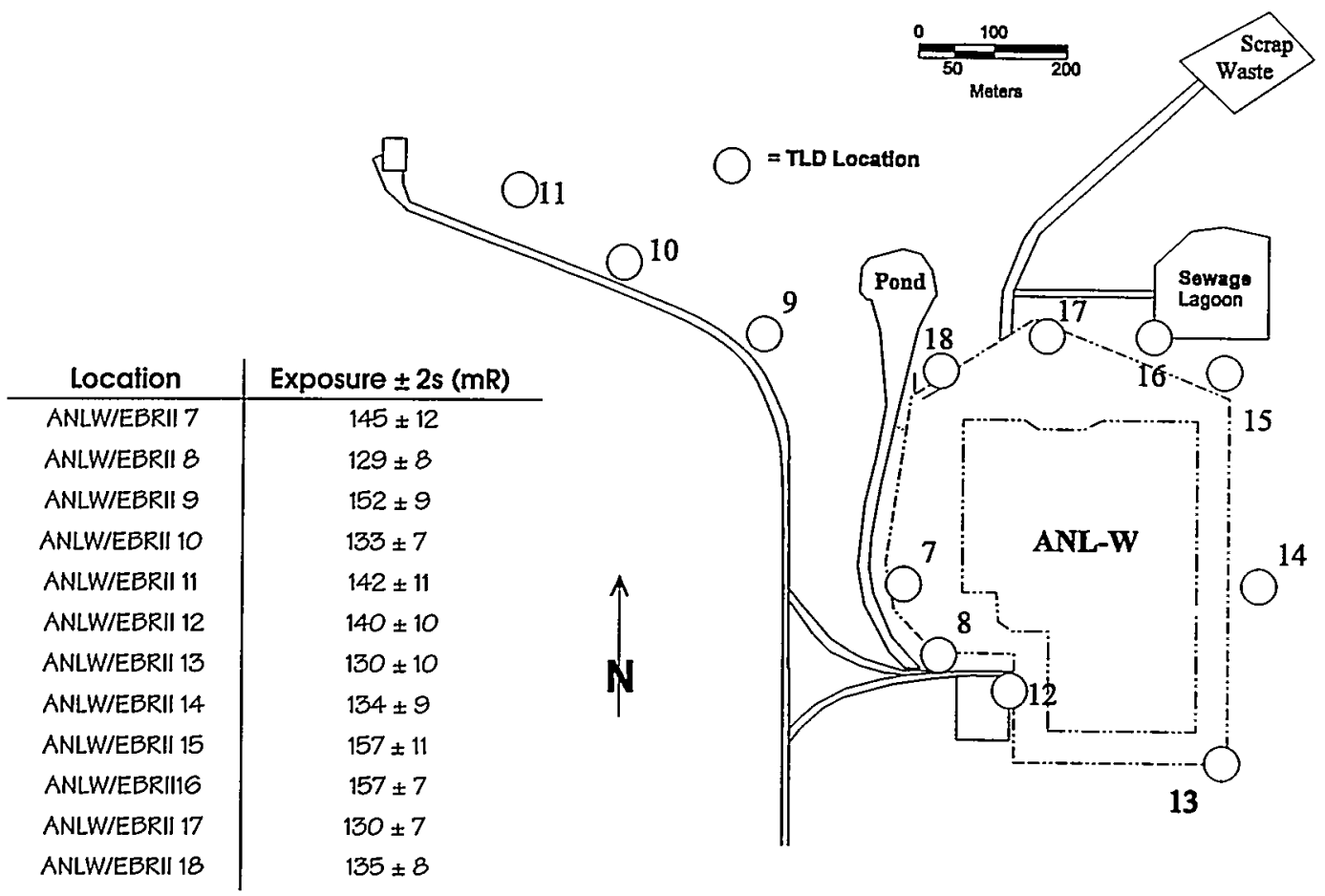

Figure 4-3. Environmental Dosimeters at ANL-W (1998)

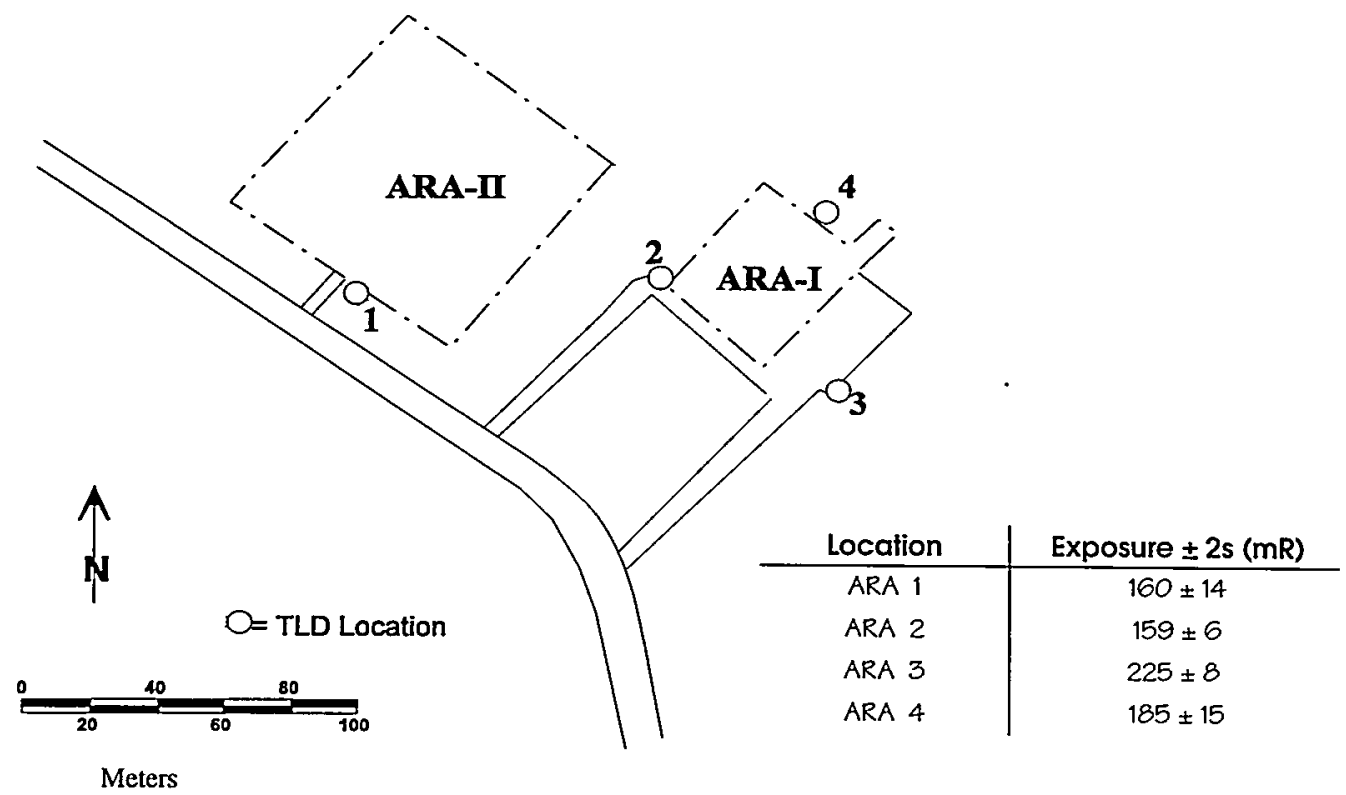

Figure 4-4. Environmental Dosimeter Measurements at ARA (1998) 


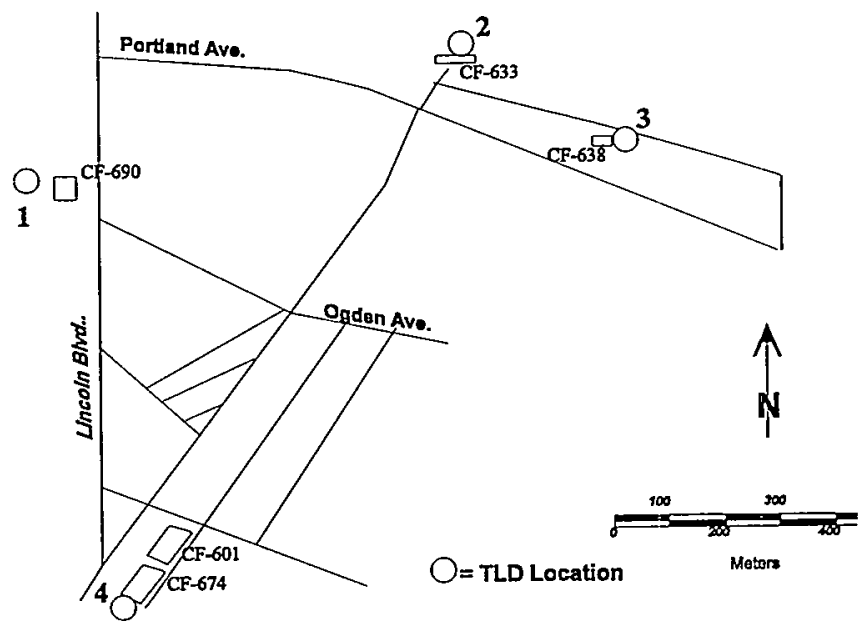

\begin{tabular}{c|c} 
Location & Exposure $\pm 2 \mathrm{~s}(\mathrm{mR})$ \\
\hline CFA 1 & $136 \pm 6$ \\
\hline CFA 2 & $130 \pm 8$ \\
\hline CFA 3 & $143 \pm 6$ \\
\hline CFA 4 & $162 \pm 11$
\end{tabular}

Figure 4.5 Environmental Dosimeter Measurements at CFA (1998)

\begin{tabular}{c|c} 
Location & Exposure $\pm 2 \mathrm{~s}(\mathrm{mR})$ \\
\hline INTEC 1 & $184 \pm 12$ \\
\hline INTEC 9 & $200 \pm 8$ \\
\hline INTEC 14 & $171 \pm 5$ \\
\hline INTEC 15 & $167 \pm 14$ \\
\hline INTEC 16 & $138 \pm 7$ \\
\hline INTEC 17 & $141 \pm 8$ \\
\hline INTEC 18 & $132 \pm 6$ \\
\hline INTEC 19 & $138 \pm 7$ \\
\hline INTEC 20 & $233 \pm 9$ \\
\hline INTEC 21 & $165 \pm 7$ \\
\hline INTEC 22 & $190 \pm 8$ \\
\hline INTEC 23 & $155 \pm 8$ \\
\hline INTEC 24 & $140 \pm 5$ \\
\hline INTEC 25 & $126 \pm 8$ \\
\hline INTEC 26 & $147 \pm 13$ \\
\hline Tree Farm 1 & $214 \pm 12$ \\
\hline Tree Farm 2 & $160 \pm 6$ \\
\hline Tree Farm 3 & $168 \pm 9$ \\
\hline Tree Farm 4 & $182 \pm 6$
\end{tabular}

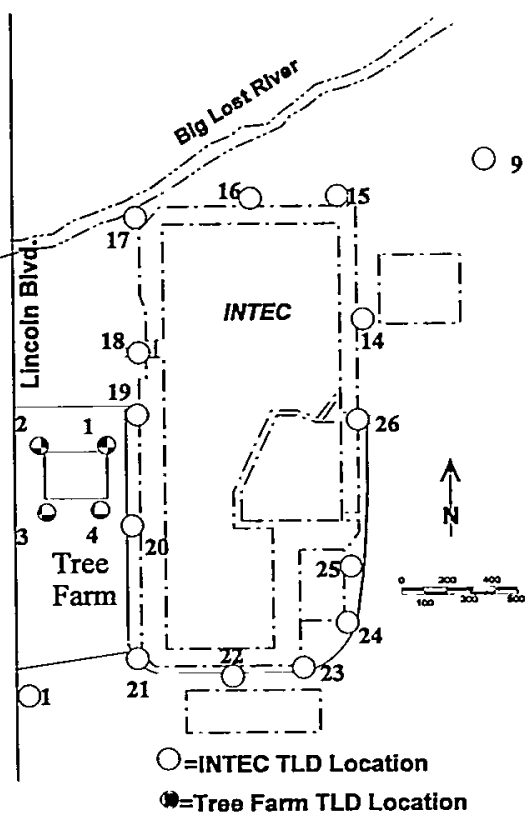

Figure 4-6. Environmental Dosimeter Measurements at INTEC (1998) 


\begin{tabular}{c|c} 
Location & Exposure $\pm 2 \mathrm{~s}(\mathrm{mR})$ \\
\hline NRF 4 & $139 \pm 6$ \\
\hline NRF 5 & $162 \pm 7$ \\
\hline NRF 11 & $143 \pm 7$ \\
\hline NRF 12 & $159 \pm 9$ \\
\hline NRF 13 & $142 \pm 9$ \\
\hline NRF 16 & $134 \pm 4$ \\
\hline NRF 17 & $140 \pm 7$ \\
\hline NRF 18 & $146 \pm 11$ \\
\hline NRF 19 & $142 \pm 9$ \\
\hline NRF 20 & $140 \pm 6$ \\
\hline NRF 21 & $138 \pm 8$
\end{tabular}

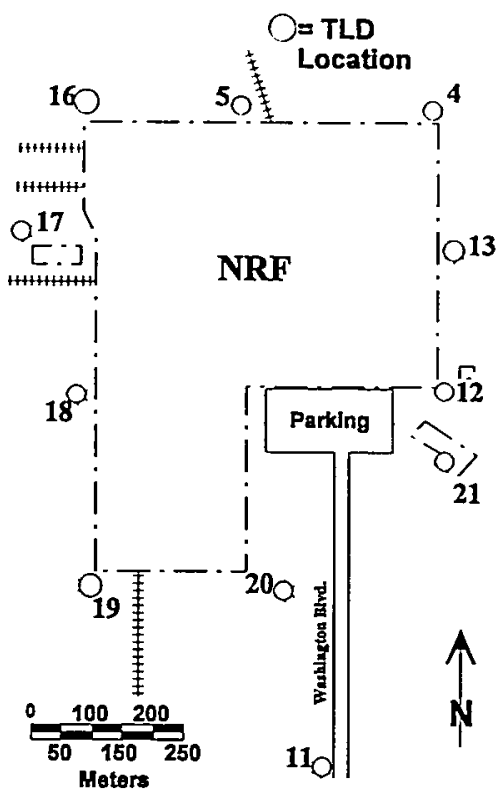

Figure 4-7. Environmental Dosimeters at NRF (1998)

\begin{tabular}{c|c} 
Location & Exposure $\pm 2 \mathrm{~s}(\mathrm{mR})$ \\
\hline PBF/SPERT 1 & $132 \pm 6$ \\
\hline PBF/SPERT 2 & $134 \pm 6$ \\
\hline PBF/SPERT 3 & $134 \pm 8$ \\
\hline PBF/SPERT 4 & $149 \pm 11$ \\
\hline PBF/SPERT 5 & $143 \pm 16$ \\
\hline PBF/SPERT 6 & $147 \pm 5$ \\
\hline PBF WERF 1 & $143 \pm 6$ \\
\hline PBFNERF 2 & $128 \pm 7$ \\
\hline PBF/WERF 3 & $137 \pm 13$ \\
\hline PBF/WERF 4 & $142 \pm 9$ \\
\hline PBFNWERF 5 & $136 \pm 11$ \\
\hline PBFNERF 6 & $139 \pm 12$ \\
\hline PBFNERF 7 & $141 \pm 11$
\end{tabular}

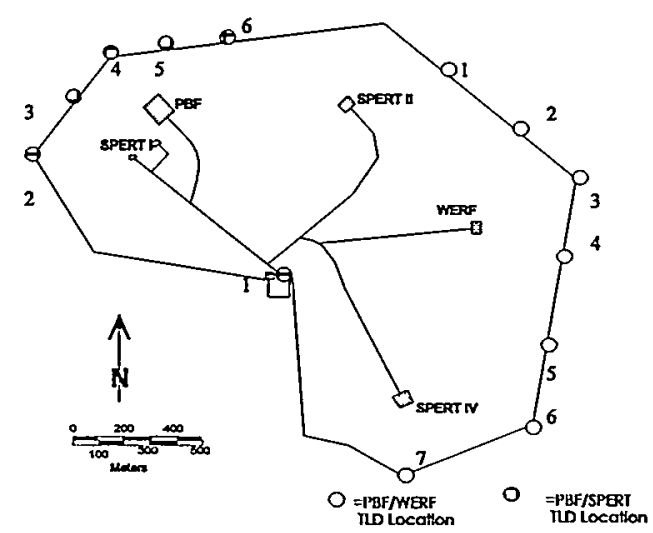

Figure 4-8. Environmental Dosimeter Measurements at PBF (1998) 


\begin{tabular}{c|c} 
Location & Exposure $\pm 2 s(\mathrm{mR})$ \\
\hline RWMC 3a & $144 \pm 5$ \\
\hline RWMC 5a & $143 \pm 9$ \\
\hline RWMC 7a & $143 \pm 11$ \\
\hline RWMC 9a & $145 \pm 7$ \\
\hline RWMC 11a & $149 \pm 7$ \\
\hline RWMC 13a & $153 \pm 15$ \\
\hline RWMC 15a & $148 \pm 8$ \\
\hline RWMC 17a & $142 \pm 6$ \\
\hline RWMC 19a & $133 \pm 7$ \\
\hline RWMC 21a & $135 \pm 6$ \\
\hline RWMC 23a & $133 \pm 9$ \\
\hline RWMC 25a & $147 \pm 6$
\end{tabular}

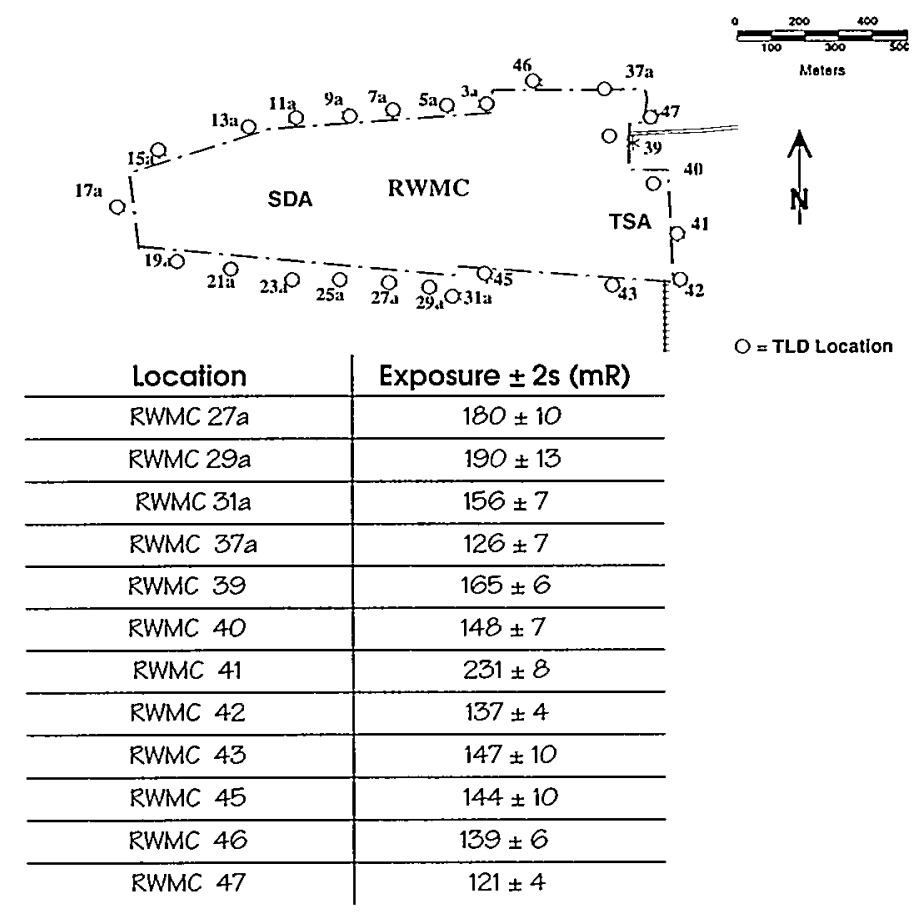

Figure 4-9. Environmental Dosimeter Measurements at RWMC (1998)

\begin{tabular}{c|c} 
Location & Exposure $\pm 2 \mathrm{~s}(\mathrm{mR})$ \\
\hline TAN/TSF 1 & $127 \pm 7$ \\
\hline TAN/TSF 2 & $133 \pm 7$ \\
\hline TAN/TSF 3 & $112 \pm 4$ \\
\hline TAN/TSF 4 & $126 \pm 8$ \\
\hline TAN/LOFT 1 & $141 \pm 7$ \\
\hline TAN/LOFT2 & $142 \pm 9$ \\
\hline TAN/LOFT 3 & $120 \pm 5$ \\
\hline TAN/LOFT 4 & $132 \pm 7$ \\
\hline TAN/LOFT5 & $140 \pm 7$ \\
\hline TAN/LOFT 6 & $138 \pm 5$ \\
\hline TAN/LOFT 7 & $136 \pm 6$ \\
\hline TAN/WRRTF 1 & $127 \pm 4$ \\
\hline TAN/WRRTF 2 & $133 \pm 4$ \\
\hline TAN/WRRTF 3 & $140 \pm 10$ \\
\hline TAN/WRRTF 4 & $119 \pm 6$
\end{tabular}

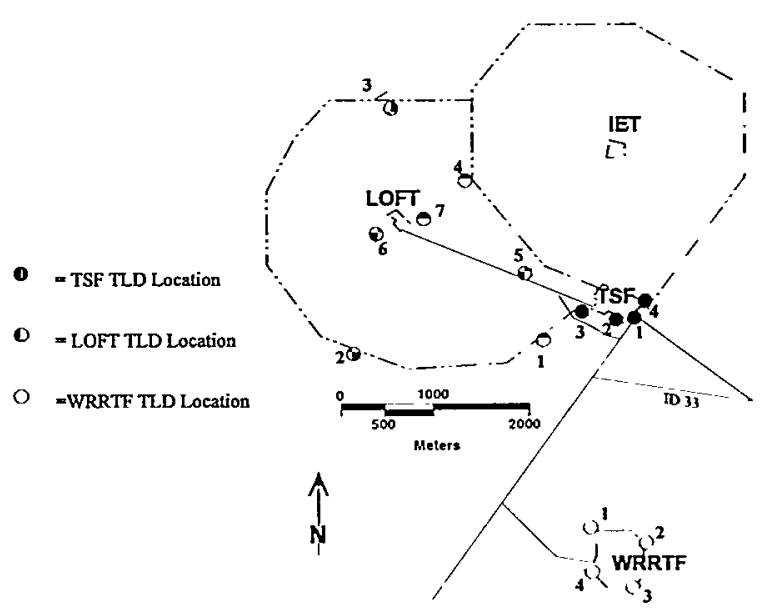

Figure 4-10 Environmental Dosimeter Measurements at TAN (1998) 


\begin{tabular}{c|c} 
Location & Exposure $\pm 2 s(\mathrm{mR})$ \\
\hline TRA1 & $154 \pm 9$ \\
\hline TRA 2 & $293 \pm 12$ \\
\hline TRA 3 & $574 \pm 58$ \\
\hline TRA 4 & $250 \pm 6$ \\
\hline TRA 5 & $193 \pm 11$ \\
\hline TRA 6 & $145 \pm 5$ \\
\hline TRA 7 & $173 \pm 14$ \\
\hline TRA 8 & $190 \pm 11$ \\
\hline TRA 9 & $149 \pm 6$ \\
\hline TRA 10 & $157 \pm 7$ \\
\hline TRA 11 & $153 \pm 6$ \\
\hline TRA 12 & $148 \pm 7$ \\
\hline TRA 13 & $150 \pm 9$
\end{tabular}

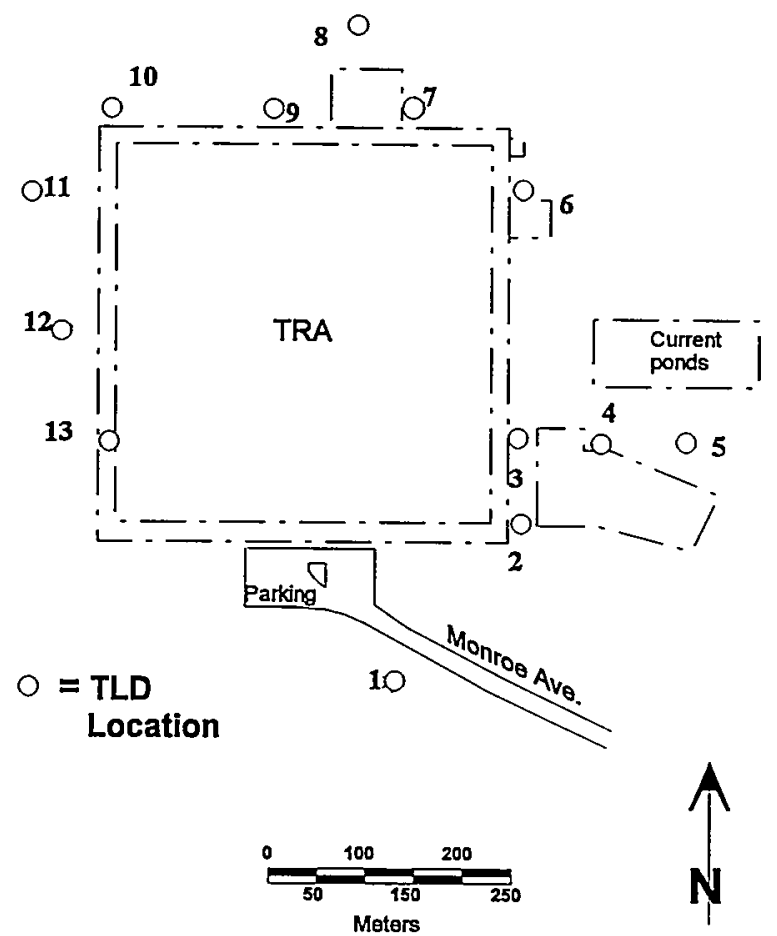

Figure 4-11. Environmental Dosimeter Measurements at TRA (1998)

\begin{tabular}{|c|c|}
\hline Location & Exposure $\pm 2 s(\mathrm{mR})$ \\
\hline LINCOLN BLVD. 1 & $129 \pm 5$ \\
\hline LINCOLN BLVD. 3 & $177 \pm 6$ \\
\hline LINCOLN BLVD. 5 & $146 \pm 9$ \\
\hline LINCOLN BLVD. 7 & $145 \pm 8$ \\
\hline LINCOLN BLVD. 9 & $140 \pm 6$ \\
\hline LINCOLN BLVD. 11 & $140 \pm 6$ \\
\hline LINCOLN BLVD. 13 & $140 \pm 6$ \\
\hline LINCOLN BLVD. 15 & $147 \pm 8$ \\
\hline LINCOLN BLVD. 17 & $147 \pm 5$ \\
\hline LINCOLN BLVD. 19 & $199 \pm 34$ \\
\hline LINCOLN BLVD. 21 & $134 \pm 6$ \\
\hline LINCOLN BLVD. 23 & $134 \pm 9$ \\
\hline LINCOLN BLVD. 25 & $131 \pm 5$ \\
\hline HIGHWAY 26 mile 266 & $135 \pm 6$ \\
\hline HIGHWAY 26 mile 268 & $131 \pm 8$ \\
\hline HIGHWAY 26 mile 270 & $133 \pm 6$ \\
\hline HIGHWAY 20 mile 264 & $139 \pm 6$ \\
\hline HIGHWAY 20 mile 266 & $121 \pm 4$ \\
\hline HIGHWAY 20 mile 268 & $129 \pm 4$ \\
\hline HIGHWAY 20 mile 270 & $126 \pm 4$ \\
\hline HIGHWAY 20 mile 272 & $119 \pm 4$ \\
\hline HIGHWAY 20 mile 274 & $111 \pm 9$ \\
\hline HIGHWAY 20 mile 276 & $123 \pm 9$ \\
\hline
\end{tabular}

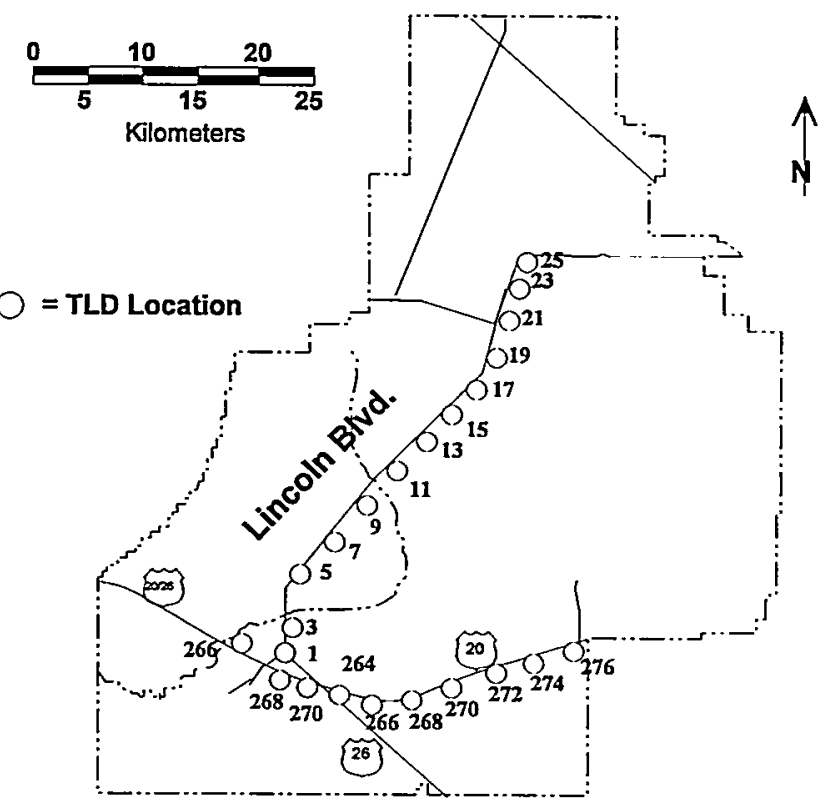

Figure 4-12. Environmental Dosimeter Measurements Lincoln Blvd. and US Highway 20 (1998) 


\section{Chapter 5}

\section{Nonradiological Environmental Monitoring Results}

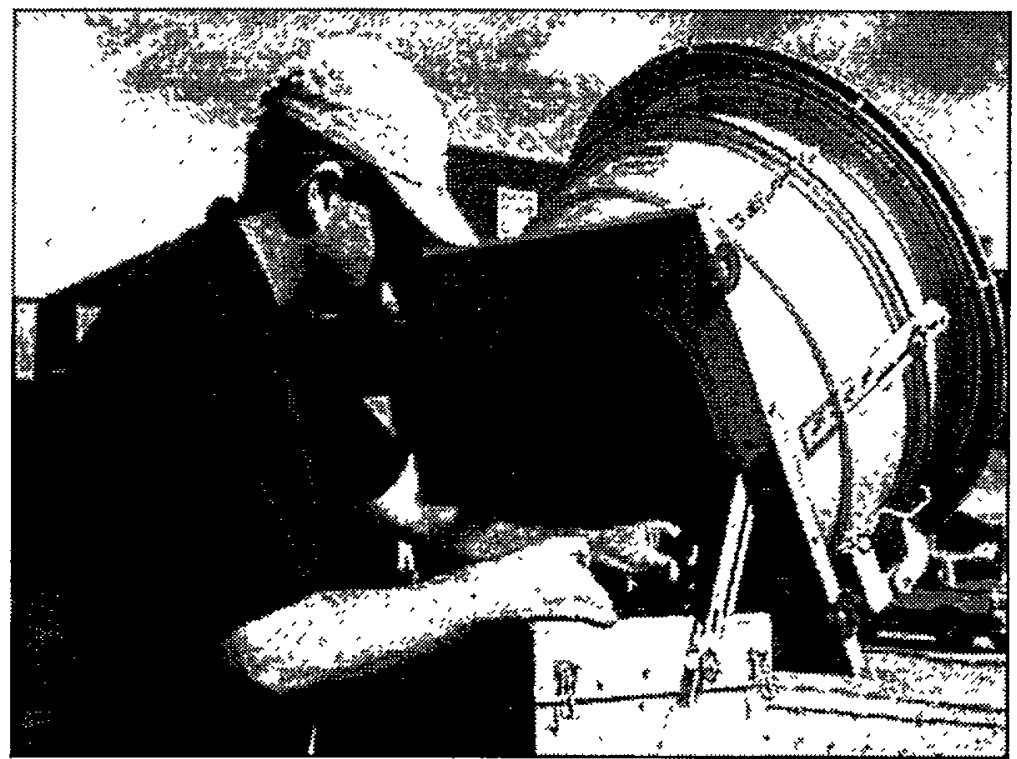





\section{NON-RADIOLOGICAL ENVIRONMENTAL MONITORING RESULTS}

\subsection{TOTAL SUSPENDED PARTICULATES}

Concentrations of total suspended particulates were measured in 1998 by both the Environmental Science and Research Foundation and the $M \& O$ contractor using filters from lowvolume air samplers. The filters are 99 percent efficient for collection of particles greater than $0.3 \mu \mathrm{m}$ in diameter. Unlike the fine particulate samplers discussed in Section 5.2, these samplers do not selectively filter out particles of a certain size range, and so measure the total amount of particulate matter.

The annual means of total suspended particulate concentrations ranged from $5 \mu \mathrm{g} / \mathrm{m}^{3}$ at ARA on the INEEL to $40 \mu \mathrm{g} / \mathrm{m}^{3}$ at Arco (Table 5-1).

Particulate concentrations were generally higher at distant and boundary locations than at the INEEL stations. The largest source of particulates in eastern Idaho is considered to be suspended dust from agricultural activities. Second and third quarter concentrations were higher than during other quarters at most of the locations, consistent with dryer conditions found in summer and autumn months. Overall, annual onsite particulate concentrations were commensurate with those observed in 1996 and 1997 (Table 5-2).

\subsection{FINE PARTICULATES $\left(\mathrm{PM}_{10}\right)$}

The EPA began using a standard for concentrations of airborne particulate matter in 1987. The standard refers only to "particles with an aerodynamic diameter less than or equal to a nominal 10 micrometers" [Reference 5-1]. Particles of this size, which can reach the lungs, are considered to be responsible for most of the adverse health effects associated with airborne particulate pollution. The air quality standards for fine particulates, generally referred to as $\mathrm{PM}_{10}$, are an annual average of
$50 \mu \mathrm{g} / \mathrm{m}^{3}$, with a maximum 24-hour concentration of $150 \mu \mathrm{g} / \mathrm{m}^{3}$.

Fifty-five valid samples were collected at Rexburg by the Foundation from January through December 1998. Concentration of fine particulates ranged from $-6 \mu \mathrm{g} / \mathrm{m}^{3}$ to $95 \mu \mathrm{g} / \mathrm{m}^{3}$, with a mean of $27 \pm 7 \mu \mathrm{g} / \mathrm{m}^{3}$. At Mountain View Middle School in Blackfoot, 48 valid samples were collected from March through December. Concentrations ranged from 1 $\mu \mathrm{g} / \mathrm{m}^{3}$ to $116 \mu \mathrm{g} / \mathrm{m}^{3}$. The mean concentration at this location was $23 \pm 6 \mu \mathrm{g} / \mathrm{m}^{3}$. At Atomic City, 44 valid samples were collected from March through December. Concentrations ranged from 1 to $100 \mu \mathrm{g} / \mathrm{m}^{3}$, with a mean of $21 \pm 6 \mu \mathrm{g} / \mathrm{m}^{3}$.

\subsection{NITROGEN DIOXIDE}

Nitrogen dioxide was monitored by the M\&O contractor at Van Buren Avenue and the Experimental Field Station (EFS) (Figure 5-1) throughout 1998. At Van Buren, quarterly mean concentrations ranged from $1.9 \mu \mathrm{g} / \mathrm{m}^{3}$ to

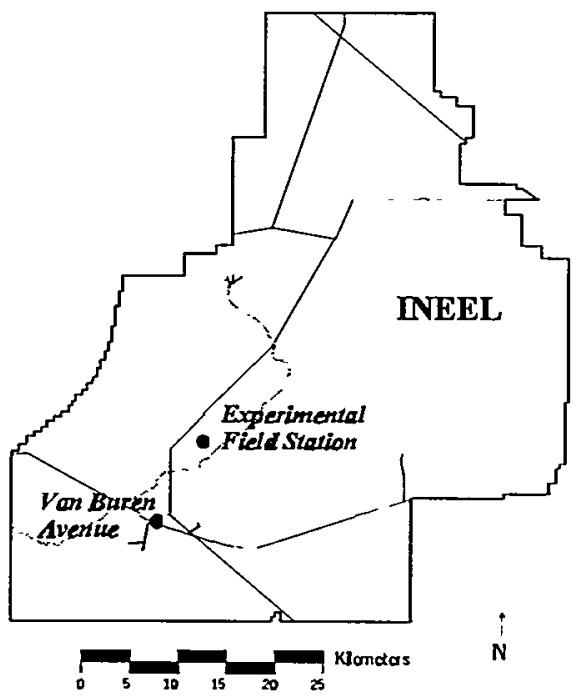

Figure 5-1. Nitrogen Oxides and Sulfur Dioxide Monitoring Locations 
Table 5-1. Particulate Concentrations in Air (1998)

\begin{tabular}{|c|c|c|c|}
\hline \multicolumn{4}{|c|}{ Environmental Science and Research Foundation Data ${ }^{a}$} \\
\hline \multirow[b]{2}{*}{ Group } & \multirow[b]{2}{*}{ Location } & \multicolumn{2}{|c|}{ Concentration $\left(\mu \mathrm{g} / \mathrm{m}^{3}\right)$} \\
\hline & & Range & Mean \\
\hline \multirow[t]{6}{*}{$\overline{\text { Distant }}$} & Blackfoot & $11-23$ & $\overline{17 \pm 8}$ \\
\hline & Craters of the Moon & $8-10$ & $9 \pm 2$ \\
\hline & Idaho Falls & $13-32$ & $23 \pm 13$ \\
\hline & Mountain View & $21-31$ & $26 \pm 7$ \\
\hline & Rexburg & $24-29$ & $27 \pm 3$ \\
\hline & & Grand Mean & $20 \pm 5$ \\
\hline \multirow[t]{8}{*}{ Boundary } & Arco & $20-60$ & $40 \pm 28$ \\
\hline & Atomic City & $1-11$ & $6 \pm 7$ \\
\hline & FAA Tower & $3-26$ & $15 \pm 16$ \\
\hline & Howe & $8-36$ & $22 \pm 19$ \\
\hline & Monteview & $10-26$ & $18 \pm 11$ \\
\hline & Mud Lake & $11-27$ & $19 \pm 11$ \\
\hline & Reno Ranch & $4-24$ & $14 \pm 13$ \\
\hline & & Grand Mean & $19 \pm 8$ \\
\hline \multirow[t]{4}{*}{ INEEL } & EFS & $5-12$ & $9 \pm 5$ \\
\hline & Main Gate & $3-14$ & $8 \pm 7$ \\
\hline & Van Buren & $7-29$ & $18 \pm 15$ \\
\hline & & Grand Mean & $12 \pm 7$ \\
\hline
\end{tabular}

\begin{tabular}{|c|c|c|c|}
\hline \multicolumn{4}{|c|}{ M\&O Contractor Data } \\
\hline \multirow[b]{2}{*}{ Group } & \multirow[b]{2}{*}{ Location } & \multicolumn{2}{|c|}{ Concentration $\left(\mu \mathrm{g} / \mathrm{m}^{3}\right)$} \\
\hline & & Range & Mean \\
\hline \multirow[t]{5}{*}{ Distant } & Blackfoot & $7-27$ & $16 \pm 7$ \\
\hline & Craters of the Moon & $6-9$ & $7 \pm 1$ \\
\hline & Idaho Falls & $2-27$ & $15 \pm 9$ \\
\hline & Rexburg & $13-24$ & $17 \pm 4$ \\
\hline & & Grand Mean & $14 \pm 4$ \\
\hline \multirow[t]{13}{*}{ INEEL } & ANL-W & $8-19$ & $13 \pm 4$ \\
\hline & ARA & $2-10$ & $5 \pm 3$ \\
\hline & CFA & $3-12$ & $6 \pm 3$ \\
\hline & EBR1 & $2-15$ & $9 \pm 4$ \\
\hline & EFS & $2-13$ & $7 \pm 4$ \\
\hline & ICPP & $5-11$ & $7 \pm 2$ \\
\hline & NRF & $4-11$ & $7 \pm 3$ \\
\hline & PBF & $5-15$ & $9 \pm 4$ \\
\hline & RWMC & $3-13$ & $8 \pm 3$ \\
\hline & TAN & $3-13$ & $8 \pm 3$ \\
\hline & TRA & $3-14$ & $7 \pm 4$ \\
\hline & VANB & $5-11$ & $8 \pm 2$ \\
\hline & (6) & Grand Mean & $8 \pm 1$ \\
\hline
\end{tabular}


Table 5-2. Ten-Year Summary of Particulate Matter Concentrations (1989-1998)

\begin{tabular}{|c|c|c|c|}
\hline \multirow[b]{2}{*}{ Year } & \multicolumn{3}{|c|}{$\begin{array}{l}\text { Group Mean Concentration a } \\
\qquad\left(\mu \mathrm{g} / \mathrm{m}^{3}\right)\end{array}$} \\
\hline & $\begin{array}{l}\text { Distant }^{\text {b }} \\
\text { Group }\end{array}$ & $\begin{array}{l}\text { Boundary } \\
\text { Group }\end{array}$ & $\begin{array}{l}\text { INEEL }^{b} \\
\text { Group }\end{array}$ \\
\hline 1989 & $40 \pm 14$ & $30 \pm 7$ & $17 \pm 2$ \\
\hline 1990 & $36 \pm 12$ & $32 \pm 8$ & $20 \pm 9$ \\
\hline 1991 & $30 \pm 20$ & $28 \pm 12$ & $18 \pm 3$ \\
\hline 1992 & $26 \pm 19$ & $23 \pm 10$ & $13 \pm 2$ \\
\hline 1993 & $21 \pm 21$ & $18 \pm 8$ & $13 \pm 3$ \\
\hline 1994 & $28 \pm 28$ & $23 \pm 7$ & $25 \pm 4$ \\
\hline 1995 & $32 \pm 30$ & $28 \pm 13$ & $20 \pm 7$ \\
\hline 1996 (Foundation) & $24 \pm 10$ & $22 \pm 5$ & $9 \pm 1$ \\
\hline 1996 (M\&O Contractor) & $25 \pm 10$ & --. & $10 \pm 2$ \\
\hline 1997 (Foundation) & $13 \pm 4$ & $19 \pm 13$ & $6 \pm 3$ \\
\hline 1997 (M\&O Contractor) & $14 \pm 3$ & --- & $9 \pm 1$ \\
\hline 1998 (Foundation) & $20 \pm 5$ & $19 \pm 8$ & $12 \pm 7$ \\
\hline 1998 (M\&O Contractor) & $14 \pm 4$ & $\ldots$ & $8 \pm 1$ \\
\hline
\end{tabular}

$3.4 \mu \mathrm{g} / \mathrm{m}^{3}$, with an annual mean of $2.7 \mu \mathrm{g} / \mathrm{m}^{3}$ $(1.5 \mathrm{ppb})$. This annual concentration is three percent of the EPA air quality standard of 100 $\mu \mathrm{g} / \mathrm{m}^{3}$ for nitrogen dioxide. The maximum 24hour concentration measured was $7.1 \mu \mathrm{g} / \mathrm{m}^{3}$ (3.8 ppb) on December 15. Data were obtained at the Van Buren station for 98 percent of the year.

Quarterly means at EFS ranged from $2.3 \mu \mathrm{g} / \mathrm{m}^{3}$ during the fourth quarter to 16.1 $\mu \mathrm{g} / \mathrm{m}^{3}$ during the first quarter. For the year, the mean concentration was $7.2 \mu \mathrm{g} / \mathrm{m}^{3}$ (3.9 $\mathrm{ppb})$, or 7 percent of the EPA standard. The maximum 24-hour average concentration occurred on January 14 , when a value of $19.2 \mu \mathrm{g} / \mathrm{m}^{3}$ (10.2 ppb) was recorded. Data were obtained at the EFS location for 98 percent of the year.

When operating, the New Waste Calcining Facility at the Idaho Nuclear Technology and Engineering Center (INTEC) is the largest single source of nitrogen dioxide at the INEEL. A graph of nitrogen dioxide concentrations observed at the two sampling locations may indicate some effect from this facility on ambient concentrations of nitrogen dioxide, particularly at EFS located approximately $5 \mathrm{~km}$ ( 3 miles) in the prevailing wind direction from INTEC (Figure 5-2). All quarterly concentrations have remained below 50 percent of the annual standard throughout the time period of monitoring. Further information on airborne nitrogen dioxide effluents released during 1998 is provided in Chapter 7.

\subsection{SULFUR DIOXIDE}

Sulfur dioxide was measured at the Van Buren Avenue monitoring location, and the analyzer operated satisfactorily for 85 percent of the year. For sulfur dioxide, there are three separate EPA standards [Reference 5-2]. The mean sulfur dioxide concentration for 1998 was $7.5 \mu \mathrm{g} / \mathrm{m}^{3}$ (2.8 ppb), or 9 percent of the annual primary air quality standard of $80 \mu \mathrm{g} / \mathrm{m}^{3}$. There is a second primary air quality standard for the maximum 24-hour concentration, not to be exceeded more than once per year. In 1998 the maximum recorded 24-hour $\mathrm{SO}_{2}$ concentration at Van Buren was

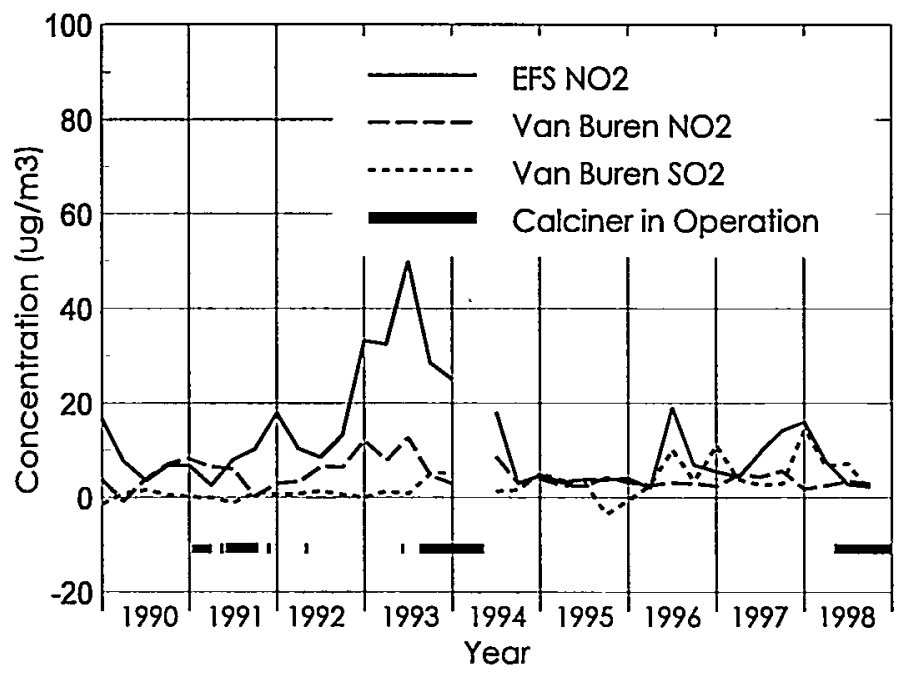

Figure 5-2. Nitrogen Dioxide and Sulfur Dioxide Concentrations at the INEEL (1990-1998) 
Table 5-3. Data for IMPROVE Samplers at CFA and Craters of the Moon (May 1992 - November 1998)

\begin{tabular}{|c|c|c|c|c|c|c|}
\hline \multirow[b]{2}{*}{ Constiłuent } & \multicolumn{2}{|c|}{$\%$ Detected $^{a}$} & \multicolumn{2}{|c|}{ Range (nanograms $/ \mathrm{m}^{3}$ ) } & \multicolumn{2}{|c|}{ Mean (nanograms $/ \mathrm{m}^{3}$ ) } \\
\hline & CFA & Craters & CFA & Craters & CFA & Craters \\
\hline$\overline{\text { Hydrogen }}$ & $\overline{100}$ & 100 & $54-430$ & $55-404$ & $152 \pm 14$ & $142 \pm 14$ \\
\hline Sodium & 10 & 12 & $<\left.d\right|^{b}-111$ & $<d l-72$ & $12 \pm 3$ & $13 \pm 2$ \\
\hline Magnesium & 14 & 8 & $<d \mid-141$ & $<d l-21$ & $8 \pm 3$ & $6 \pm 0.6$ \\
\hline Aluminum & 50 & 36 & $<d l-370$ & $<d l-425$ & $43 \pm 13$ & $29 \pm 12$ \\
\hline Silicon & 99 & 100 & $<d l-831$ & $<d l-905$ & $134 \pm 30$ & $107 \pm 25$ \\
\hline Phosphorus & 4.0 & 6.0 & $<d \mid-78$ & $<d l-29$ & $4.0 \pm 1.7$ & $3.4 \pm 0.8$ \\
\hline Sulfur & 100 & 100 & $27-525$ & $17-547$ & $179 \pm 19$ & $150 \pm 18$ \\
\hline Chlorine & 2.1 & 7.0 & $<d l-6.3$ & $<d l-57$ & $2.6 \pm 0.2$ & $3.2 \pm 1.1$ \\
\hline Potassium & 99 & 100 & $<d l-354$ & $3-309$ & $39 \pm 10$ & $32 \pm 10$ \\
\hline Calcium & 100 & 100 & $4-357$ & $4-396$ & $49 \pm 12$ & $40 \pm 10$ \\
\hline Titanium & 84 & 80 & $<d l-20$ & $<d l-24$ & $5.1 \pm 0.8$ & $4.4 \pm 0.8$ \\
\hline Vanadium & 36 & 49 & $<d l-4.7$ & $<d l-8.5$ & $1.8 \pm 0.2$ & $1.8 \pm 0.3$ \\
\hline Chromium & 33 & 27 & $<d l-3.8$ & $<d l-3.6$ & $1.2 \pm 0.1$ & $1.1 \pm 0.1$ \\
\hline Manganese & 33 & 36 & $<d l-7.3$ & $<d l-5.4$ & $1.2 \pm 0.2$ & $1.1 \pm 0.2$ \\
\hline Iron & 100 & 100 & $2-209$ & $2-256$ & $27 \pm 7$ & $24 \pm 7$ \\
\hline Nickel & 11 & 10 & $<d \mid-0.3$ & $<d l-0.3$ & $0.09 \pm 0.01$ & $0.09 \pm 0.01$ \\
\hline Copper & 45 & 83 & $<d \mid-107$ & $<d l-0.5$ & $1.3 \pm 2.2$ & $0.2 \pm 0.02$ \\
\hline Zinc & 93 & 97 & $<d l-70$ & $<d l-4$ & $2.2 \pm 1.4$ & $1.3 \pm 0.2$ \\
\hline Arsenic & 59 & 45 & $<d \mid-1.1$ & $<d l-1.0$ & $0.2 \pm 0.04$ & $0.2 \pm 0.04$ \\
\hline Lead & 80 & 82 & $<d l-6.9$ & $<d l-2.4$ & $0.7 \pm 0.2$ & $0.6 \pm 0.1$ \\
\hline Selenium & 64 & 43 & $<d l-0.8$ & $<d l-0.5$ & $0.2 \pm 0.04$ & $0.1 \pm 0.02$ \\
\hline Bromine & 98 & 99 & $<d \mid-8.4$ & $<$ dl -7.7 & $1.8 \pm 0.3$ & $1.7 \pm 0.3$ \\
\hline
\end{tabular}

$25.6 \mu \mathrm{g} / \mathrm{m}^{3}$ (9.6 ppb), which did not approach the standard of $365 \mu \mathrm{g} / \mathrm{m}^{3}$.

In addition to the primary standards, there is a secondary ambient air quality standard. The secondary standard refers to the maximum 3-hour concentration, which can not exceed $1300 \mu \mathrm{g} / \mathrm{m}^{3}$ more than once per year. The highest 3-hour concentration was $33.3 \mu \mathrm{g} / \mathrm{m}^{3}$ $(12.5 \mathrm{ppb})$; this is approximately 2.6 per cent of the secondary standard.

\subsection{IMPROVE SAMPLERS}

Interagency Monitoring of Protected Visual Environment (IMPROVE) samplers have operated continuously at Craters of the Moon National Monument and Central Facilities Area
(CFA) since the spring of 1992 . The most recent data available are through November 1998. A summary of the data for hydrogen and elements sodium through lead on the periodic table are shown in Table 5-3. Both locations exhibit similar elemental concentrations.

Several elements measured, including aluminum, silicon, calcium, titanium, and iron, are derived from soils, and show a seasonal variation with lower values during the winter when the ground is often covered by snow. Potassium may be derived from soils, but is also a component of smoke.

Other elements are considered tracers of various industrial and urban activities. Lead and bromine, for example, result from automobile emissions. Annual concentrations of lead 


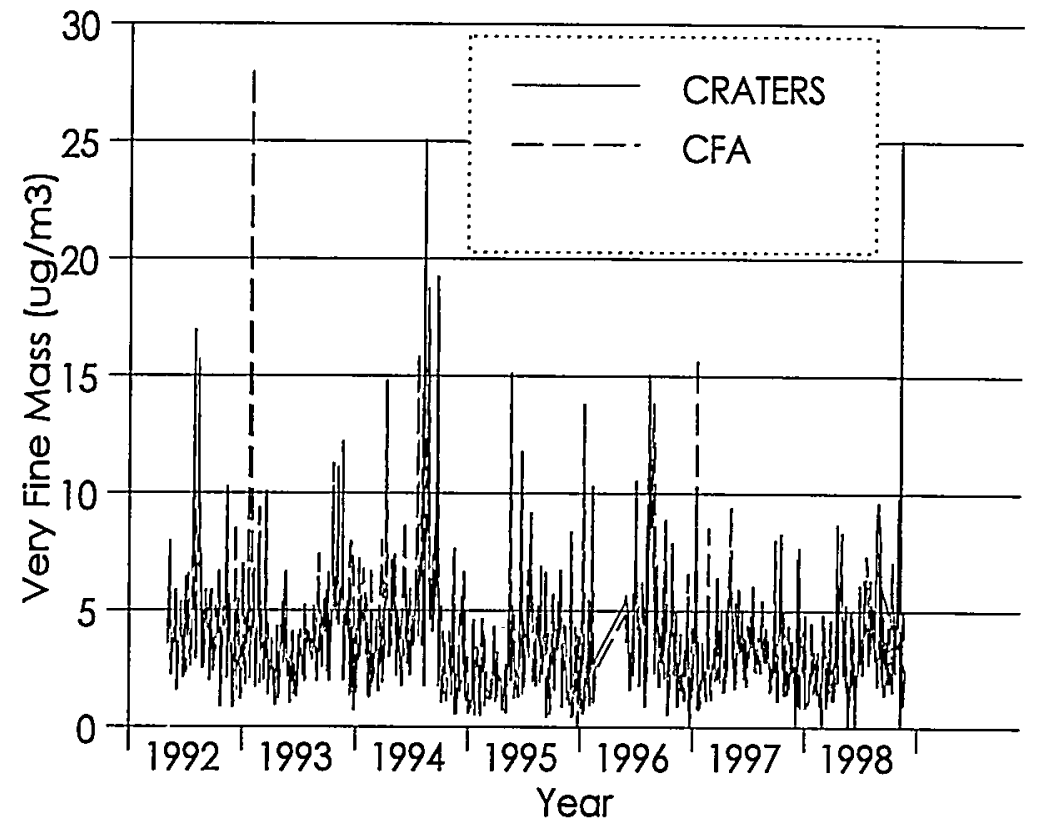

\section{Figure 5-3. Very Fine Mass $\left(\mathrm{PM}_{2.5}\right)$ Concentrations at Craters of the Moon and CFA (1992-1998)}

conditions, most notably during January 1993 at CFA.

\subsection{STORM WATER MONITORING}

The National Pollutant Discharge Elimination System (NPDES) General Permit sets monitoring requirements for three types of facilities which are directly applicable to the INEEL: (1) Emergency Planning and Community Right to Know Act (EPCRA) Section 313 facilities, (2) coal piles, and (3) land disposal units, incinerators, boilers, and industrial furnaces. Additional monitoring locations are sampled for characterization purposes to evaluate the effectiveness of pollution abatement programs.

The Idaho Nuclear Technology and Engineering Center (INTEC) qualifies as an EPCRA Section 313 Facility because of the quantity of nitric acid used at the plant. For INTEC, the water priority chemical is nitric acid, and the monitoring parameters are $\mathrm{pH}$, nitrate plus nitrite, oil and grease, biological oxygen demand (BOD), chemical oxygen demand (COD), total suspended solids (TSS), total Kjeldahl nitrogen (TKN), total phosphorous, and acute whole effluent toxicity.

An industrial coal pile for steam generation is also located at the INTEC. The NPDES General Permit lists parameters which must be monitored in storm water discharges from coal piles as: oil and grease, pH, TSS, copper, nickel, and zinc.

The Central Facilities Area (CFA) Landfill III. the Subsurface Disposal Area (SDA) at the Radioactive Waste Management Area Complex (RWMC), and the Waste Experimental Reduc- 
tion Facility (WERF) incinerator all require monitoring. Land disposal units and incinerators require monitoring for oil and grease, $\mathrm{pH}$, chemical oxygen demand (COD), acute whole effluent toxicity, TKN, total and dissolved magnesium, total dissolved solids, total organic carbon, arsenic, barium, cadmium, chromium, cyanide, lead, mercury, selenium, and silver.

The INEELStorm Water Monitoring program was redesigned in 1997 on the recommendations of an independent evaluation of previous monitoring efforts, regulations, other DOE programs, and historical storm water monitoring data. The number of storm water monitoring points was reduced from 21 to 16 . In 1998 , nine of the 16 points were sampled during one or more of five different snow melt and/or storm events. The results of this sampling are given in Table 5-4. Benchmarks for the storm water monitoring parameters specified in the NPDES General Permit are also listed in Table 5-4.

Seven samples exhibited concentrations of one or more of the measured parameters exceeding the corresponding benchmark. A sample collected at the INTEC (CPP-MP-1) contained concentrations of TSS, nitrogen (nitrate plus nitrite), aluminum, copper, iron, manganese, and zinc exceeding the respective benchmarks. Another sample collected at another INTEC sampling point (CPP-MP-2) contained concentrations of TSS and iron in excess of the benchmarks. Two samples collected at PBF (PBF-MP-3 and PBF-MP-4) exhibited concentrations of iron in excess of the NPDES benchmark. Two samples collected at the RWMC (at locations RWMC-MP-2 and RWMCMP-4) contained iron and zinc in excess of the benchmark; one of these samples also contained concentrations of nitrogen (nitrate plus nitrite) and TSS which exceeded the respective benchmarks. Two samples collected at the WERF (locations WRF-MP-1 and WRF-MP-2) contained concentrations of zinc which exceeded the benchmark.

While Table 5-4 lists several analyses in which the sample concentrations exceeded the respective benchmarks, the only permit required limits at the INEEL are for $\mathrm{pH}$ in runoff from the coal piles at the INTEC, and in 1998 all INTEC samples had values within the specified limits of pH 6 to 9 . The benchmarks in Table 5-4, according to the 1995 NPDES General Permit [Reference 3-6], are not effluent limits; rather they are performance targets above which there is a level of concern. The level of concern is a concentration at which a storm water discharge might impair water quality or affect human health from ingestion of water or fish. These levels have been used by EPA to determine whether a storm water discharge from a given facility merits further monitoring. Exceeding the benchmarks does not necessarily imply water quality violations in the receiving water body, especially in cases like the INEEL, where the only natural permanent surface stream is the Big Lost River. The NPDES General Permit is concerned with Waters of the U.S., water bodies used for purposes that could affect interstate commerce or recreation. In this case, water quality in the Big Lost River was not affected because the discharge infiltrated in manmade surface channel within a short distance of the discharge point. 
Table 5-4. Non-radiological Storm Water Monitoring Data (1998)

\begin{tabular}{|c|c|c|c|c|c|c|}
\hline Location & Parameter & Units & 98 avg & $98 \mathrm{~min}$ & $98 \max$ & Benchmark \\
\hline INTEC & Conductivity & us & 183 & 26 & 406 & $N A^{a}$ \\
\hline \multirow[t]{38}{*}{ CPP-MP-1 } & Disolved Oxygen & $m g / L$ & 7.67 & 6.4 & 8.94 & NA \\
\hline & $\mathrm{pH}$ & us & 7.89 & 7.35 & 8.41 & 6 \\
\hline & Salinity & $\%$ & 0 & $O$ & 0 & NA \\
\hline & Turbidity & NTU & 738 & 476 & 999 & NA \\
\hline & Biological Oxygen Demand & $\mathrm{mg} / \mathrm{L}$ & 1.45 & $1.00 \mathrm{U}$ & 2.4 & 30 \\
\hline & Chemical Oxygen Demand & mg/L & 9.53 & 5.6 & 13 & 120 \\
\hline & Nitrogen, Nitrate+Nitrite & $m g-N / L$ & 1.307 & 0.42 & 1.9 & $0.68 \checkmark^{b}$ \\
\hline & Total Phosphorus & $\mathrm{mg} / \mathrm{L}$ & 0.913 & 0.2 & 2.2 & 2 \\
\hline & Nitrogen, Total Kjeldahl & mg/L & 1.387 & 0.4 & 3 & NA \\
\hline & Total Oil \& Grease & $\mathrm{mg} / \mathrm{L}$ & 2.1 & 1.5 & 2.6 & 15 \\
\hline & TSS & $\mathrm{mg} / \mathrm{L}$ & & 25 & 270 & $100 \checkmark$ \\
\hline & Silver & $m g / L$ & ND & -- & -- & 0.0318 \\
\hline & Silver $[F]$ & $m g / L$ & ND & -- & -- & 0.0318 \\
\hline & Aluminum & $m g / L$ & 42.4 & 42.4 & 42.4 & $7.5 \checkmark$ \\
\hline & Aluminum $[F]$ & $\mathrm{mg} / \mathrm{L}$ & ND & -- & -- & 7.5 \\
\hline & Arsenic & $\mathrm{mg} / \mathrm{L}$ & 0.02 & 0.02 & 0.015 & 0.1685 \\
\hline & Arsenic $[F]$ & $\mathrm{mg} / \mathrm{L}$ & ND & -- & -- & 0.1685 \\
\hline & Barium & $m g / L$ & 0.703 & 0.703 & 0.703 & $N A$ \\
\hline & Barium $[\mathrm{F}]$ & $\mathrm{mg} / \mathrm{L}$ & ND & -- & -- & $N A$ \\
\hline & Beryllium & $\mathrm{mg} / \mathrm{L}$ & ND & -- & -- & 0.13 \\
\hline & Beryllium [F] & $\mathrm{mg} / \mathrm{L}$ & ND & -- & -- & 0.13 \\
\hline & Calcium & $\mathrm{mg} / \mathrm{L}$ & 92.7 & 92.7 & 92.7 & $N A$ \\
\hline & Calcium $[F]$ & $\mathrm{mg} / \mathrm{L}$ & 12.1 & 12.1 & 12.1 & $N A$ \\
\hline & Cadmium & $\mathrm{mg} / \mathrm{L}$ & ND & -- & -- & 0.0159 \\
\hline & Cadmium $[F]$ & $\mathrm{mg} / \mathrm{L}$ & ND & -- & -- & 0.0159 \\
\hline & Cobalt & $m g / L$ & 0.03 & 0.03 & 0.025 & $N A$ \\
\hline & Cobalt $[F]$ & $\mathrm{mg} / \mathrm{L}$ & ND & -- & -. & $N A$ \\
\hline & Chromium & $\mathrm{mg} / \mathrm{L}$ & 0.06 & 0.06 & 0.057 & $N A$ \\
\hline & Chromium $[\mathrm{F}]$ & $\mathrm{mg} / \mathrm{L}$ & ND & -- & -- & $N A$ \\
\hline & Copper & $\mathrm{mg} / \mathrm{L}$ & 0.07 & 0.07 & 0.07 & $0.0636 \checkmark$ \\
\hline & Copper [F] & $\mathrm{mg} / \mathrm{L}$ & ND & -- & -- & 0.0636 \\
\hline & Iron & $\mathrm{mg} / \mathrm{L}$ & 55.3 & 55.3 & 55.3 & $1.0 \checkmark$ \\
\hline & Iron $[F]$ & $\mathrm{mg} / \mathrm{L}$ & 0.112 & 0.112 & 0.112 & 1 \\
\hline & Mercury & $m g / L$ & & 0.00027 & 0.00027 & 0.0024 \\
\hline & Mercury $[F]$ & $\mathrm{mg} / \mathrm{L}$ & ND & -- & -- & 0.0024 \\
\hline & Potassium & $m g / L$ & 11 & 11 & 11 & NA \\
\hline & Potassium [F] & $\mathrm{mg} / \mathrm{L}$ & 1.99 & 1.99 & 1.99 & NA \\
\hline & Magnesium & $\mathrm{mg} / \mathrm{L}$ & 24 & 24 & 24 & NA \\
\hline
\end{tabular}

- NA indicates no benchmark exists for the parameter.

${ }^{\circ} \checkmark$ indicates the mean value from the detected 1998 data exceeded the associated benchmark. 
Table 5-4 (continued). Non-radiological Storm

Water Monitoring Data (1998)

\begin{tabular}{|c|c|c|c|c|c|c|}
\hline Location & Parameter & Units & $98 \mathrm{avg}$ & $98 \mathrm{~min}$ & $98 \max$ & Benchmark \\
\hline INTEC & Magnesium [F] & $m g / L$ & 1.77 & 1.77 & 1.77 & $N A^{a}$ \\
\hline CPP-MP-1 & Manganese & $\mathrm{mg} / \mathrm{L}$ & 1.06 & 1.06 & 1.06 & $1.0 V^{b}$ \\
\hline \multirow[t]{17}{*}{ (continued) } & Manganese $[\mathrm{F}]$ & $\mathrm{mg} / \mathrm{L}$ & ND & -- & -- & 1 \\
\hline & Sodium & $\mathrm{mg} / \mathrm{L}$ & 7.73 & 7.73 & 7.73 & NA \\
\hline & Sodium $[\mathrm{F}]$ & $m g / L$ & 5.47 & 5.47 & 5.47 & NA \\
\hline & Nickel & $\mathrm{mg} / \mathrm{L}$ & 0.09 & 0.09 & 0.087 & 1.4 \\
\hline & Nickel $[F]$ & $m g / L$ & ND & - & -- & 1.4 \\
\hline & Lead & $\mathrm{mg} / \mathrm{L}$ & 0.05 & 0.05 & 0.047 & 0.0816 \\
\hline & Lead $[F]$ & $\mathrm{mg} / \mathrm{L}$ & ND & -- & -- & 0.0816 \\
\hline & Antimony & $\mathrm{mg} / \mathrm{L}$ & ND & - & -. & NA \\
\hline & Antimony $[\mathrm{F}]$ & $\mathrm{mg} / \mathrm{L}$ & ND & -- & -- & NA \\
\hline & Selenium & $\mathrm{mg} / \mathrm{L}$ & ND & -- & -- & 0.2385 \\
\hline & Selenium $[F]$ & $\mathrm{mg} / \mathrm{L}$ & ND & -- & -- & 0.2385 \\
\hline & Thallium & $\mathrm{mg} / \mathrm{L}$ & ND & -- & -- & $N A$ \\
\hline & Thallium $[F]$ & $\mathrm{mg} / \mathrm{L}$ & ND & -- & -- & NA \\
\hline & Vanadium & $\mathrm{mg} / \mathrm{L}$ & 0.07 & 0.07 & 0.067 & NA \\
\hline & Vanadium $[\mathrm{F}]$ & $\mathrm{mg} / \mathrm{L}$ & ND & -- & -- & $N A$ \\
\hline & Zinc & $\mathrm{mg} / \mathrm{L}$ & 0.58 & 0.58 & 0.58 & $0.1170 \checkmark$ \\
\hline & $\operatorname{Zinc}[F]$ & $\mathrm{mg} / \mathrm{L}$ & ND & -- & -- & 0.117 \\
\hline INTEC & Conductivity & us & 67 & 67 & 67 & NA \\
\hline \multirow[t]{15}{*}{ CPP-MP-2 } & $\mathrm{pH}$ & & 7.07 & 7.07 & 7.07 & 6 \\
\hline & Chemical Oxygen Demand & $m g / L$ & 32 & 32 & 32 & 120 \\
\hline & Total Oil \& Grease & $\mathrm{mg} / \mathrm{L}$ & ND & -- & - & 15 \\
\hline & TSS & $\mathrm{mg} / \mathrm{L}$ & 689 & 689 & 689 & $100 \checkmark$ \\
\hline & Silver & $\mathrm{mg} / \mathrm{L}$ & ND & -- & - & 0.0318 \\
\hline & Aluminum & $\mathrm{mg} / \mathrm{L}$ & 5.18 & 5.18 & 5.18 & 7.5 \\
\hline & Arsenic & $\mathrm{mg} / \mathrm{L}$ & ND & - & -- & 0.1685 \\
\hline & Barium & $\mathrm{mg} / \mathrm{L}$ & 0.123 & 0.123 & 0.123 & NA \\
\hline & Beryllium & $\mathrm{mg} / \mathrm{L}$ & ND & - & -- & 0.13 \\
\hline & Calcium & $\mathrm{mg} / \mathrm{L}$ & 28.1 & 28.1 & 28.1 & NA \\
\hline & Cadmium & $m g / L$ & ND & -- & -- & 0.0159 \\
\hline & Cobalt & $\mathrm{mg} / \mathrm{L}$ & ND & -- & -- & NA \\
\hline & Chromium & $\mathrm{mg} / \mathrm{L}$ & 0.01 & 0.01 & 0.01 & $N A$ \\
\hline & Copper & $m g / L$ & ND & -- & -- & 0.0636 \\
\hline & Iron & $\mathrm{mg} / \mathrm{L}$ & 6.63 & 6.63 & 6.63 & $1.0 \checkmark$ \\
\hline
\end{tabular}

- NA indicates no benchmark exists for the parameter.

b $\checkmark$ indicates the mean value from the detected 1998 data exceeded the associated benchmark. 
Table 5-4 (continued). Non-radiological Storm

Water Monitoring Data (1998)

\begin{tabular}{|c|c|c|c|c|c|c|}
\hline Location & Parameter & Units & $98 \mathrm{avg}$ & $98 \mathrm{~min}$ & $98 \max$ & Benchmark \\
\hline INTEC & Mercury & $\mathrm{mg} / \mathrm{L}$ & ND & -- & -- & 0.0024 \\
\hline CPP-MP-2 & Potassium & $\mathrm{mg} / \mathrm{L}$ & 1.73 & 1.73 & 1.73 & $N A^{a}$ \\
\hline \multirow[t]{10}{*}{ (continued) } & Magnesium & $\mathrm{mg} / \mathrm{L}$ & 4.24 & 4.24 & 4.24 & $N A$ \\
\hline & Manganese & $\mathrm{mg} / \mathrm{L}$ & 0.11 & 0.11 & 0.11 & 1 \\
\hline & Sodium & mg/L & 9.75 & 9.75 & 9.75 & NA \\
\hline & Nickel & $\mathrm{mg} / \mathrm{L}$ & ND & -- & -- & 1.4 \\
\hline & Lead & $\mathrm{mg} / \mathrm{L}$ & 0.01 & 0.01 & 0.005 & 0.0816 \\
\hline & Antimony & $\mathrm{mg} / \mathrm{L}$ & ND & -- & -- & NA \\
\hline & Selenium & $m g / L$ & ND & -- & -- & 0.2385 \\
\hline & Thallium & $\mathrm{mg} / \mathrm{L}$ & ND & -- & -. & $N A$ \\
\hline & Vanadium & $\mathrm{mg} / \mathrm{L}$ & 0.024 & 0.024 & 0.024 & NA \\
\hline & Zinc & $\mathrm{mg} / \mathrm{L}$ & 0.079 & 0.079 & 0.079 & 0.117 \\
\hline PBF & E. Coli & & Absent & Absent & Absent & NA \\
\hline \multirow[t]{22}{*}{ PBF-MP-3 } & Total Coliform & & Present & Present & Present & NA \\
\hline & Conductivity & us & 55 & 45 & 65 & NA \\
\hline & Disolved Oxygen & $\mathrm{mg} / \mathrm{L}$ & 10.35 & 10.35 & 10.35 & NA \\
\hline & $\mathrm{pH}$ & & 7.49 & 7.42 & 7.56 & 6 \\
\hline & Salinity & $\%$ & $O$ & $O$ & 0 & NA \\
\hline & Turbidity & NTU & 81 & 81 & 81 & NA \\
\hline & $\begin{array}{l}\text { Biological Oxygen Demand } \\
\text { (5-day) }\end{array}$ & mg/L & 2 & 2 & 2 & 30 \\
\hline & Cyanide & $\mathrm{mg} / \mathrm{L}$ & ND & -- & -- & NA \\
\hline & Chemical Oxygen Demand & $m g / L$ & 32 & 32 & 32 & 120 \\
\hline & Coliform (count) & CFU/1O & 0 & 0 & 0 & NA \\
\hline & Nitrogen, Nitrate+Nitrite & $m g-N / L$ & 0.13 & 0.13 & 0.13 & 0.68 \\
\hline & Total Phosphorus & $\mathrm{mg} / \mathrm{L}$ & 0.13 & 0.13 & 0.13 & 2 \\
\hline & TDS & $\mathrm{mg} / \mathrm{L}$ & 90 & 90 & 90 & NA \\
\hline & Nitrogen, Total Kjeldahl & $\mathrm{mg} / \mathrm{L}$ & 0.8 & 0.8 & 0.8 & NA \\
\hline & TOC & $\mathrm{mg} / \mathrm{L}$ & 6.8 & 6.8 & 6.8 & NA \\
\hline & Total Oil \& Grease & $\mathrm{mg} / \mathrm{L}$ & ND & -- & -- & 15 \\
\hline & TSS & $\mathrm{mg} / \mathrm{L}$ & 9.8 & 9.8 & 9.8 & 100 \\
\hline & Silver & $\mathrm{mg} / \mathrm{L}$ & ND & -- & -- & 0.0318 \\
\hline & Silver $[F]$ & $\mathrm{mg} / \mathrm{L}$ & ND & -- & $-\cdot$ & 0.0318 \\
\hline & Aluminum & $\mathrm{mg} / \mathrm{L}$ & 1.49 & 1.49 & 1.49 & 7.5 \\
\hline & Aluminum $[F]$ & $\mathrm{mg} / \mathrm{L}$ & 0.383 & 0.383 & 0.383 & 7.5 \\
\hline & Arsenic & $\mathrm{mg} / \mathrm{L}$ & ND & -- & $-\cdot$ & 0.1685 \\
\hline
\end{tabular}


Table 5-4 (continued). Non-radiological Storm Water Monitoring Data (1998)

\begin{tabular}{llccccc}
\hline Location & Parameter & Units & 98 avg & 98 min & 98 max & Benchmark \\
PBF & Arsenic [F] & mg/L & ND & - & -- & 0.1685 \\
PBF-MP-3 & Barium & $\mathrm{mg} / \mathrm{L}$ & 0.053 & 0.053 & 0.053 & $\mathrm{NA}^{\mathrm{a}}$ \\
(continued) & Barium [F] & $\mathrm{mg} / \mathrm{L}$ & 0.032 & 0.032 & 0.032 & $\mathrm{NA}$ \\
& Beryllium & $\mathrm{mg} / \mathrm{L}$ & $\mathrm{ND}$ & -- & -- & 0.13 \\
& Beryllium [F] & $\mathrm{mg} / \mathrm{L}$ & $\mathrm{ND}$ & -- &.- & 0.13 \\
\hline
\end{tabular}

- NA indicates no benchmark exists for the parameter. 


\section{Chapter 6 Ground Water}

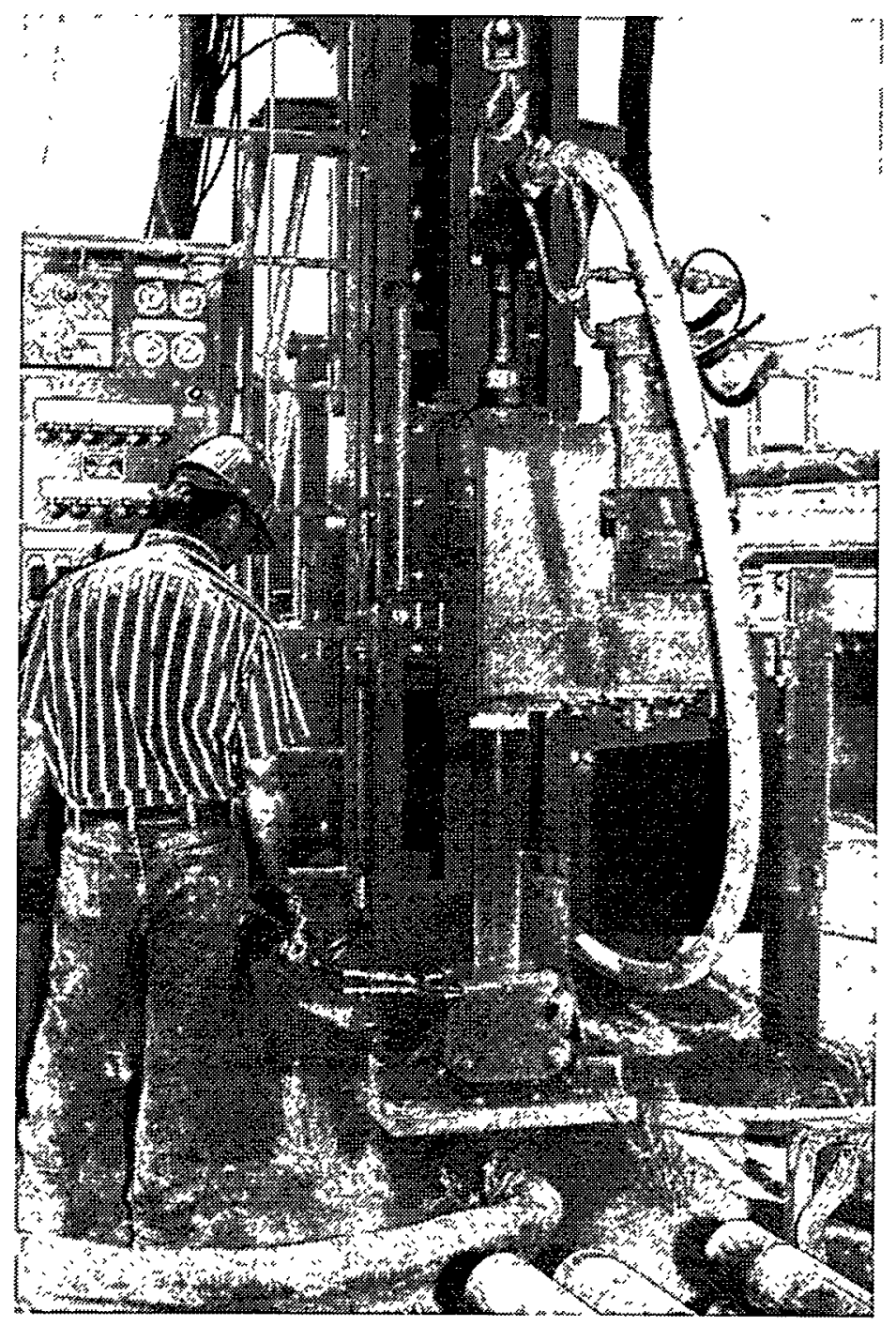




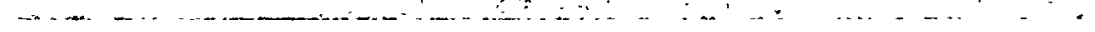




\section{GROUND WATER}

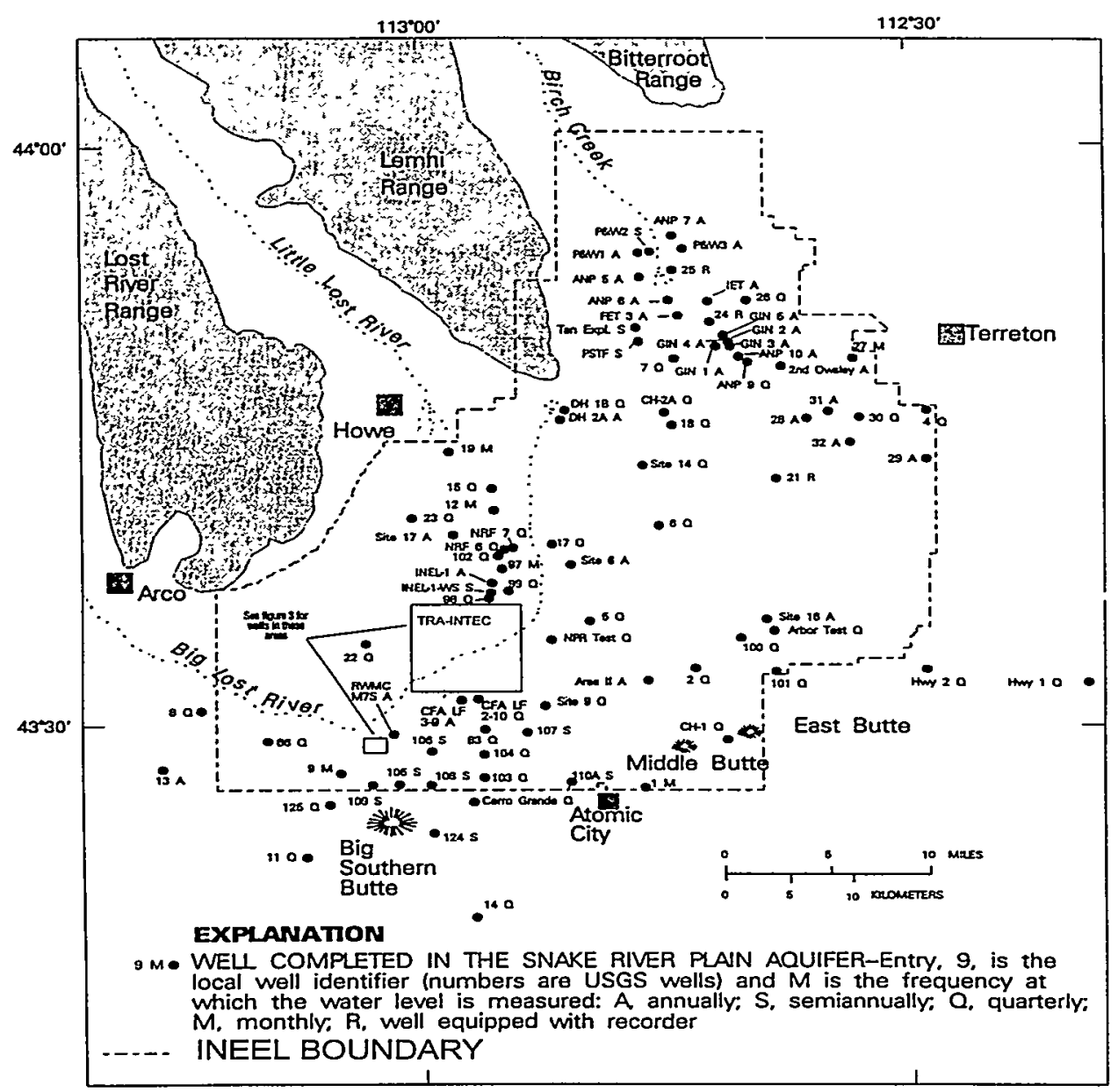

Figure 6-1. USGS Well Locations

\subsection{AQUIFER STUDIES}

\section{Program Information}

The U.S. Geological Survey (USGS). The USGS is responsible for conducting groundwater monitoring, analyses, and studies of the Snake River Plain aquifer under and adjacent to the INEEL. This is done through an extensive network of strategically placed observation wells on and near the Site (Figures 6-1 and 6-2).
The Snake River Plain aquifer, which underlies the INEEL, serves as one of the primary sources for drinking water and crop irrigation in the Snake River Basin. A brief description of the hydrogeology of the INEEL and the movement of water in the Snake River Plain aquifer was given in Chapter 1. Further information may be found in USGS publications.

The USGS has investigated hydrologic conditions at the INEEL since 1949, and currently 


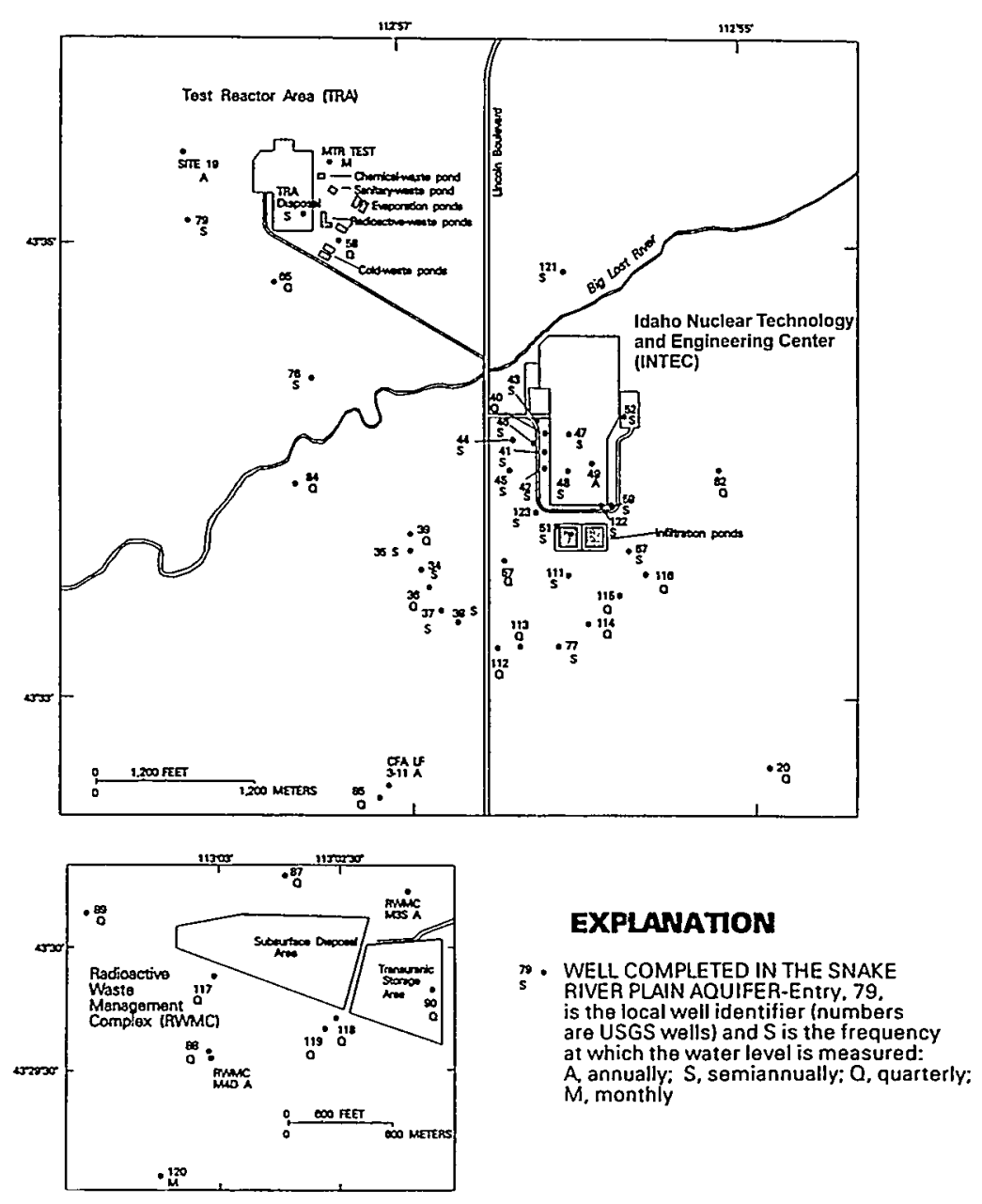

Figure 6-2. USGS Well Locations at INTEC,TRA and RWMC

conducts an extensive monitoring program for the aquifer and perched water bodies above it. This program includes collection of samples on the INEEL and at locations beyond the southern and western boundaries. The USGS routine ground-water surveillance program was summarized in Chapter 3 . In 1998, the routine program included collection of 346 samples for radionuclides and inorganic constituents including trace elements, and 53 samples for purgeable organic compounds. In addition, as part of the 1998 NRF sampling program, the USGS collected quarterly samples from 13 NRF wells. A total of 60 samples were collected and analyzed for radioactivity, inorganic constituents, and purgeable organic compounds.

Various USGS reports contain maps showing the frequency of water level measurements and water sample collections. Recent information has also been published on the shape and extent of contaminant plumes (the spread of various contaminants in the water of the aquifer and perched water from INEEL facilities) between 1992 and 1995 [Reference 6-1]. A summary of this information is presented in this section.

The USGS also conducts special studies of the ground water of the Snake River Plain. A summary of such studies published in 1998 is provided in this section. These special studies provide more specific geological, chemical, and hydrological information on the flow and recharge of the aquifer and the movements of radiochemical and chemical substances in the ground water. One important special USGS investigation is an ongoing annual sampling effort in the area between the southern boundary of the INEEL and Hagerman, usually called the Magic Valley Study. This study was prompted by public concern that radiochemical and chemical constituents generated by INEEL facilities could migrate through the Snake River Plain aquifer to the Snake River in the Twin Falls-Hagerman area. This study is summarized below and has been described in a special Fact Sheet [Reference 6-5]. 
USGS data are available upon request from the USGS INEEL Project Office; this office can also provide information for securing copies of their reports.

M\&O Contractor. The M\&O contractor conducts ground-water monitoring in support of Wastewater Land Application Permit requirements at INTEC and TAN, as well as surveillance monitoring at INTEC. More detailed information and data will be included in the 1998 Environmental Monitoring Program Report for the Idaho National Engineering and Environmental Laboratory.

\section{Summary of USGS Special Studies}

Distribution of Selected Radiochemical and Chemical Constituents in Perched Ground Water, Idaho National Engineering Laboratory, Idaho, 1992-95 [Reference 6-2]

This report presents an analysis of waterlevel and water-quality data collected from perched ground water at the INEEL during 1992-95. During 1992-95, tritium concentrations in water from wells completed in deep perched ground water at the TRA generally decreased or were variable. During JulyOctober 1995, concentrations ranged from less than the reporting level to $158 \pm 5 \mathrm{pCi} / \mathrm{mL}$. The maximum tritium concentration in the shallow perched ground water at the TRA during $1992-95$ was $3,940 \pm 60 \mathrm{pCi} / \mathrm{mL}$ in January 1992. By October 1995, the tritium concentration in water from the same well had decreased to $22.4 \pm 0.9 \mathrm{pCi} / \mathrm{mL}$. Tritium concentrations in water from wells at the TRA were affected by distance of the well from the radioactive waste ponds, depth of the water below the ponds, monthly variations in the amount of tritium discharged, discontinued use of the radioactive waste ponds, radioactive decay, and dilution from non-radioactive water.

During $1992-95,{ }^{90} \mathrm{Sr}$ concentrations in water from wells completed in deep perched ground water at the TRA were variable. During October 1995, concentrations ranged from 6.4 \pm 0.9 to $143 \pm 5 \mathrm{pCi} / \mathrm{L}$. Cesium $-137,{ }^{51} \mathrm{Cr}$, and ${ }^{60} \mathrm{Co}$ all were detected in water from a shallow well near the leaky radioactive-waste pond retention basin.

Dissolved chromium concentrations in perched ground water at the TRA during 1995 were from less than 5 to 590 micrograms per liter $(\mu \mathrm{g} / \mathrm{L})$. The largest concentrations were in water from wells north and west of the radioactive waste ponds. Dissolved sodium concentrations ranged from 7.1 to 1,200 milligrams per liter ( $\mathrm{mg} / \mathrm{L})$ in 1995. Dissolved sulfate concentrations were from 18 to $3,900 \mathrm{mg} / \mathrm{L}$. The largest concentrations of sodium and sulfate were in water from a well near the chemical waste pond.

During 1992-95, tritium concentrations in water from wells completed in deep perched ground water near the INTEC infiltration ponds generally decreased because of decreased disposal; ${ }^{90} \mathrm{Sr}$ concentrations were variable. In October 1995, tritium concentrations ranged from less than the reporting level to $1.0 \pm 0.2$ $\mathrm{pCi} / \mathrm{mL}$, and ${ }^{90} \mathrm{Sr}$ concentrations were below the reporting level in all wells.

During 1992-95, concentrations of sodium, chloride, sulfate, and nitrite in water from wells completed in perched ground water near the INTEC infiltration ponds were similar to the concentrations of the constituents in the discharged wastewater.

During 1992-94, concentrations of ${ }^{241} \mathrm{Am}$ and ${ }^{238} \mathrm{Pu}$ were above the reporting level in one sample each from a well completed in perched ground water at the RWMC. Other radionuclides had concentrations below the reporting levels.

Purgeable Organic Compounds in Water at or near the Idaho National Engineering Laboratory, Idaho, 1992-95 [Reference 6-3]

Water samples from 54 wells and six surface-water sites at or near the INEEL were analyzed for 63 purgeable organic compounds during 1992-95. The samples were collected 
and analyzed as a continuation of water-quality studies initiated in 1987 and conducted by the USGS in cooperation with the DOE. Water from 53 of the wells comes from the Snake River Plain aquifer. The remaining well was completed in a perched water zone above the Snake River Plain aquifer.

Water samples from 23 wells completed in the Snake River Plain aquifer contained detectable concentrations of at least one of 14 selected purgeable organic compounds. The most commonly detected compounds were carbon tetrachloride, chloroform, 1,1,1-trichloroethane, and trichloroethylene. The concentrations of most compounds were less than the laboratory reporting levels. The water sample from the perched zone contained detectable concentrations of 18 purgeable organic compounds.

\section{Preliminary Water-Surface Elevations and Boundary of the 100-Year Peak Flow in the Big Lost River at the Idaho National Engineering and Environmental Laboratory, Idaho [Reference 6-4]}

Delineation of areas at the INEEL which would be inundated by a 100 -year peak flow in the Big Lost River is needed by the DOE to fulfill flood-plain regulatory requirements. The Big Lost River flows southeastward about 50 miles $(80 \mathrm{~km})$ through an alluvium-filled valley onto the eastern Snake River Plain. The 35-mile (56 $\mathrm{km}$ ) downstream reach of the Big Lost River that flows across the INEEL and ends in a series of playas is of particular concern. Many anthropogenic features in the study area affect flood hydraulics and flow.

Thirty-seven channel cross-sections were surveyed to develop and apply a one-dimensional hydraulic model to calculate water-surface elevations and estimate the areas of inundation for the 100-year peak flow in the Big Lost River. From the western boundary of the INEEL to the diversion dam, a peak flow of 7,270 cubic feet per second ( 206 cubic meters per second) was simulated. On the basis of a structural analysis, the diversion dam was assumed incapable of retaining high flows and was therefore not included in model simulations. However, the diversion channel does affect flows downstream from the dam. Model results indicated that 6,210 cubic feet per second (176 cubic meters per second) would flow downstream from the dam in the Big Lost River if the dam did not exist, and the remainder would flow in the diversion channel. Where State Highway 26 crosses the Big Lost River, about 47 percent of the flow would pass under the bridge and the remainder would flow over the highway about 1200 feet (366 meters) southeast of the bridge. The calculated water-surface elevation was about one foot $(30$ $\mathrm{cm}$ ) higher than the highway. Where Lincoln Boulevard crosses the Big Lost River near the INTEC, the calculated water surface was about 0.4 foot $(12 \mathrm{~cm})$ higher than the road. About 24 percent of the flow would pass through the culverts, and the remainder would flow over the road. At the railroad bridge near the INTEC, the calculated water surface averaged 0.5 foot (15 $\mathrm{cm})$ higher than the railroad. About 40 percent of the flow would pass under the bridge, and the remainder would flow over the railroad. Model results also indicated that 30 percent of the total flow would pass under the bridge at Lincoln Boulevard near the Naval Reactors Facility, and the remainder would flow over the road.

The 100-year peak flow boundary at the INEEL was defined. The flood plain was as narrow as 120 feet (37 meters) near the western boundary of the study area and as wide as 1.2 miles $(1.9 \mathrm{~km})$ near the INTEC. The northern part of the INTEC and its entrance road would be the only flooded facility. The Experimental Field Station, about 2.5 miles $(4.0 \mathrm{~km})$ downstream from the plant, would also be flooded.

Discretion must be exercised in the use of these model results. The simplifying assumptions used in this and other one-dimensional models and the limited number of cross-sec- 
tions used prevent precise simulation of the flood hazard. The model gives a reasonable determination of the water-surface elevations and the inundated areas for the 100-year peak flow. However, these one-dimensional model results are preliminary and are primarily intended to provide guidance in the construction of a more stringent flow model. Application of more stringent models (two-dimensional) is needed to refine and to better delineate the extent of possible flooding of the Big Lost River at the INEEL.

Fact Sheet: Effect of Activities at the Idaho National Engineering and Environmental Laboratory on the Water Quality of the Snake River Plain Aquifer in the Magic Valley Study [Reference 6-5]

Radiochemical and chemical constituents in wastewater generated at facilities of the INEEL have been discharged to waste disposal ponds and wells since the early 1950 s. Public concern has been expressed that some of these constituents could migrate through the Snake River Plain aquifer to the Snake River in the Twin Falls-Hagerman area. Because of these concerns, the DOE requested that the USGS conduct three studies to gain a greater understanding of the chemical water quality in the aquifer. One study consisted of a one-time sampling effort for radionuclides, trace elements, and organic compounds in the eastern part of the A\&B Irrigation District in Minidoka County. Another ongoing study involves sampling for tritium from 19 springs on the north side of the Snake River in the Twin Falls-Hagerman area. A third study, an ongoing annual sampling effort in the area between the southern boundary of the INEEL and Hagerman (the Magic Valley study area), is being conducted with the Idaho Department of Water Resources in cooperation with the DOE. Data from a variety of radiochemical and chemical constituents were published in eight previous reports, and data discussed in this fact sheet were taken from these reports. An evaluation of data collected during the first four years of this study showed no pattern of water-quality change for radionuclides, because concentrations randomly increased or decreased. The inorganic constituent data showed no statistical change between sampling rounds. Examination of the data contained in previous reports demonstrates that gross alpha and gross beta radioactivity seen in ground water in the Magic Valley study area are probably caused by natural radioactivity from local aquifer rocks. Nitrate concentrations found in the study area are probably attributable to local sources, including agricultural fertilizers, effluent from animal-feeding operations and food-processing industries, and septic tanks. Purgeable organic compounds observed in Magic Valley ground water are also attributable to local sources. Analyses for all of these constituents in samples of ground water taken in the region between the immediate proximity of facilities on the INEEL and water use points in the Magic Valley indicate no contaminants from the INEEL are reaching the Magic Valley study area.

\section{Strontium Distribution Coefficients of Basalt Core Samples from the Idaho National Engineering and Environmental Laboratory, Idaho [Reference 6-6]}

Strontium distribution coefficients $\left(K_{d} s\right)$ were measured for 24 basalt core samples collected from selected sites at the INEEL. The investigation is being conducted by the USGS and Idaho State University in cooperation with the DOE. Batch experiments were used to measure $K_{d} s$ of basalt core samples using an aqueous solution representative of wastewater in waste-disposal ponds at the INEEL. Calculated strontium Kds of the 24 basalt core samples ranged from $3.6 \pm 1.3$ to $29.4 \pm 1.6$ milliliters per gram. These results indicate a narrow range of variability in the strontium sorptive capacities of basalt relative to those of the sedimentary materials at the INEEL. The narrow range of the basalt $\mathrm{K}_{\mathrm{d}} \mathrm{s}$ can be attributed to physical and chemical properties of the 
basalt, and to compositional changes in the equilibrated solutions after being mixed with the basalt. The small $K_{d} s$ indicate that basalt is not a major contributor in preventing or retarding the movement of ${ }^{90} \mathrm{Sr}$ in solution.

Strontium Distribution Coefficients of Surficial and Sedimentary Interbed Samples from the Idaho National Engineering and Environmental Laboratory, Idaho [Reference 6-7]

Strontium distribution coefficients $\left(K_{d} s\right)$ were measured for 21 surficial and 17 sedimentary interbed samples collected from sediment cores from selected sites at the Idaho National Engineering and Environmental Laboratory (INEEL) to help assess the variability of strontium $\mathrm{K}_{\mathrm{s}} \mathrm{s}$ at the INEEL as part of an ongoing investigation of strontium chemicaltransport properties. Batch experimental techniques were used to determine strontium $\mathrm{K}_{\mathrm{d}} \mathrm{s}$ of the sediments. Measured strontium $\mathrm{K}_{\mathrm{d}} \mathrm{s}$ of the surficial and interbedded sediments ranged from $26 \pm 1$ to $328 \pm 41$ milliliters per gram. These results indicate significant variability in the strontium sorptive capacities of surficial and interbedded sediments at the INEEL. Some of this variability can be attributed to physical and chemical properties of the sediment; other variability may be due to compositional changes in the equilibrated solutions after being mixed with the sediment.

Radiochemical and Chemical Constituents in Water from Selected Wells and Springs from the Southern Boundary of the Idaho National Engineering and Environmental Laboratory to the Hagerman Area, Idaho, 1997 [Reference 6-8]

The U.S. Geological Survey and the Idaho Department of Water Resources, in cooperation with the U.S. Department of Energy, sampled 18 sites as part of the fourth round of a long-term project to monitor water quality of the Snake River Plain aquifer from the southern boundary of the Idaho National Engineering and Environmental Laboratory to the Hagerman area. Water samples were collected and analyzed for selected radiochemical and chemical constituents. The samples were collected from seven domestic wells, six irrigation wells, two springs, one dairy well, one observation well, and one stock well. Two quality-assurance samples also were collected and analyzed.

None of the radiochemical or chemical constituents exceeded the established maximum contaminant levels for drinking water. Many of the radionuclide- and inorganic constituent concentrations were greater than their respective reporting levels.

\subsection{NON-RADIOLOGICAL MONITORING}

\section{USGS}

Sampling for purgeable (volatile) organic compounds in ground water was conducted by the USGS at the INEEL during 1998. Water samples from one onsite production well and 11 ground-water monitoring wells were collected and submitted to the USGS National Water Quality Laboratory in Arvada, Colorado, for analysis of 61 purgeable organic compounds. A USGS report describes the methods used to collect the water samples and ensure sampling and analytical quality [Reference 6-9]. Concentrations above the laboratory reporting level of $0.2 \mu \mathrm{g} / \mathrm{L}$ were detected for seven purgeable organic compounds: carbon tetrachloride; chloroform; tetrachloroethylene; 1,1,1-trichloroethane; trichloroethylene; dichloro-difluoro-methane; and total toluene (Table 6-1). The Radioactive Waste Management Complex (RWMC) production well contained detectable concentrations of purgeable organic compounds. Annual average concentrations of these compounds in this well remained about the same as those observed in 1997. Carbon tetrachloride concentrations 
Table 6-1. Purgeable Organic Compounds in USGS Well Samples (1998)

\begin{tabular}{|c|c|c|c|c|c|c|c|c|}
\hline Well ID & Date & $\begin{array}{c}\text { Carbon } \\
\text { Tetra- } \\
\text { chloride }\end{array}$ & Chloroform & $\begin{array}{l}\text { Tetrachloro- } \\
\text { ethylene }\end{array}$ & $\begin{array}{c}1,1,1- \\
\text { trichloro- } \\
\text { ethane }\end{array}$ & $\begin{array}{l}\text { Trichloro- } \\
\text { ethylene }\end{array}$ & $\begin{array}{l}\text { Dichloro- } \\
\text { difluoro- } \\
\text { methane }\end{array}$ & $\begin{array}{c}\text { Total } \\
\text { Toluene }\end{array}$ \\
\hline \multirow[t]{2}{*}{34} & $04 / 14$ & $<d l^{*}$ & $<d l$ & <dl & $0.2^{b_{f}}$ & $<$ dl & 0.2 & $<$ dl \\
\hline & $10 / 15$ & $<d l$ & $<d l$ & $<d l$ & 0.2 & $<d l$ & 0.1 & $<d l$ \\
\hline \multirow[t]{2}{*}{38} & $04 / 21$ & $<d l$ & $<d l$ & $<d l$ & $<d l$ & $<d l$ & 0.16 & $<d \mid$ \\
\hline & $10 / 19$ & $<d l$ & $<d l$ & $<d l$ & 0.2 & $<d l$ & 0.1 & $<d l$ \\
\hline \multirow[t]{2}{*}{65} & $04 / 28$ & $<d l$ & $<d l$ & $<d l$ & 0.3 & $<d l$ & 0.1 & $<d \mid$ \\
\hline & $10 / 21$ & $<d l$ & $<d l$ & $<d l$ & 0.3 & $<d l$ & 0.2 & $<d l$ \\
\hline \multirow[t]{2}{*}{77} & 04106 & $<d l$ & $<d l$ & $<d l$ & 0.4 & $<d l$ & 0.2 & $<d l$ \\
\hline & $10 / 13$ & $<$ dl & $<d l$ & $<d l$ & 0.3 & $<d l$ & $<$ edl & $<$ dl \\
\hline \multirow[t]{2}{*}{84} & $04 / 08$ & $<d l$ & $<d l$ & $<d l$ & $<d l$ & $<d l$ & 0.2 & $<d l$ \\
\hline & $10 / 14$ & $<d l$ & $<d l$ & $<d l$ & 0.1 & $<d l$ & $<d l$ & $<d l$ \\
\hline \multirow[t]{4}{*}{87} & $01 / 14$ & 2.3 & $<d l$ & $<d l$ & 0.2 & 0.6 & $<d l$ & $<d l$ \\
\hline & $04 / 22$ & 2.4 & $<d l$ & $<d l$ & 0.2 & 0.6 & $<d l$ & $<d l$ \\
\hline & $07 / 08$ & 2.2 & $<d l$ & $<d l$ & $<d l$ & 0.6 & 0.3 & $<d l$ \\
\hline & $10 / 15$ & 2.2 & 0.1 & $<d l$ & 0.2 & 0.5 & $<d l$ & $<d l$ \\
\hline \multirow[t]{4}{*}{88} & $01 / 20$ & 1.8 & 0.5 & $<d l$ & 0.2 & 0.8 & $<d l$ & 0.2 \\
\hline & $04 / 14$ & 1.8 & 0.5 & $<d l$ & 0.2 & 0.7 & $<d l$ & 0.3 \\
\hline & $07 / 21$ & 1.5 & 0.5 & $<d l$ & $<d l$ & 0.7 & $<d l$ & $<d l$ \\
\hline & $10 / 27$ & 1.7 & 0.4 & $<d l$ & 0.2 & 0.7 & $<d l$ & $<d l$ \\
\hline \multirow[t]{4}{*}{90} & $01 / 20$ & 3.2 & 0.4 & $<d i$ & 0.4 & 1.4 & $<d l$ & $<d l$ \\
\hline & $03 / 31$ & 3.3 & 0.4 & 0.1 & 0.4 & 1.3 & $<d l$ & $<d l$ \\
\hline & $07 / 21$ & 2.9 & 0.3 & $<d l$ & 0.4 & 1.3 & $<d l$ & $<d l$ \\
\hline & $10 / 22$ & 2.8 & 0.4 & 0.1 & 0.3 & 1.2 & $<d l$ & $<d l$ \\
\hline \multirow[t]{2}{*}{92} & $03 / 31$ & 260 & 540 & 50 & 55 & 360 & $<d l$ & $<d l$ \\
\hline & $01 / 14$ & 3.0 & 0.5 & $<d l$ & 0.4 & 1.1 & $<d l$ & $<d l$ \\
\hline \multirow[t]{3}{*}{120} & $04 / 22$ & 2.8 & 0.5 & $<d l$ & 0.3 & 1.0 & $<d l$ & $<a l$ \\
\hline & $07 / 08$ & 2.2 & 0.4 & $<d l$ & 0.2 & 0.8 & 0.2 & $<d l$ \\
\hline & $10 / 15$ & 4.8 & 1.0 & 0.1 & 0.5 & 1.8 & $<d l$ & $<d l$ \\
\hline \multicolumn{9}{|l|}{ RWMC } \\
\hline M7S & $07 / 07$ & 4.7 & 0.6 & 0.3 & 0.6 & 2.1 & 0.3 & $<d l$ \\
\hline \multirow[t]{11}{*}{ Production } & $01 / 14$ & 5.3 & 0.7 & 0.2 & 0.6 & 2.2 & $<d l$ & $<d \mid$ \\
\hline & $02 / 17$ & 5.2 & 0.8 & 0.2 & 0.6 & 2.5 & $<d l$ & $<d \mid$ \\
\hline & $03 / 16$ & 6.5 & 1.0 & 0.2 & 0.8 & 2.8 & $<d l$ & $<d l$ \\
\hline & $04 / 22$ & 5.0 & 0.9 & 0.2 & 0.6 & 2.5 & $<d l$ & $<d l$ \\
\hline & $05 / 18$ & 5.3 & 0.8 & $<d l$ & 0.6 & 2.3 & $<d l$ & $<d l$ \\
\hline & $06 / 16$ & 5.3 & 0.8 & $<d l$ & 0.6 & 2.4 & $<d l$ & $<d l$ \\
\hline & 07108 & 4.2 & 0.7 & $<d l$ & 0.5 & 2.0 & 0.3 & $<d l$ \\
\hline & $08 / 13$ & 4.1 & 0.6 & 0.2 & 0.6 & 1.9 & $<d l$ & $<d l$ \\
\hline & $09 / 10$ & 4.3 & 0.7 & $<d l$ & 0.5 & 2.2 & $<d l$ & $<d l$ \\
\hline & $10 / 15$ & 4.5 & 0.8 & 0.2 & 0.5 & 2.1 & $<d l$ & $<d l$ \\
\hline & $12 / 15$ & 4.1 & 0.7 & 0.2 & 0.5 & 2.1 & $<d l$ & $<d l$ \\
\hline \multicolumn{2}{|c|}{$\begin{array}{l}\text { EPA maximum } \\
\text { contaminant level }(\mathrm{MCL})^{c}\end{array}$} & 5 & 100 & 5 & 200 & 5 & & 1000 \\
\hline \multicolumn{9}{|c|}{ a $<d l$ means concentration is less than the reporting limit for the analysis. } \\
\hline \multicolumn{9}{|c|}{$b$ Concentrations expressed in $\mu g / L$. Only samples for which one or more value exceeded the detection limit are included. } \\
\hline
\end{tabular}

remained at levels near the $M C L$ at the end of 1998 (Table 6-1).

\section{M\&O Contractor}

The M\&O contractor Environmental Monitoring Unit routinely samples drinking water from wells and distribution systems at INEEL facilities for volatile organic compounds. At the TAN Technical Support Facility (TSF), the production wells and distribution systems have been sampled more frequently since the discovery in 1987 that trichloroethylene concentrations in samples collected from TSF Well \#1 exceeded 
the EPA MCL. The concentration of trichloroethylene in this well remained near but not above the MCL in the one sample collected in 1998 (Table 6-2).

In 1988, an aerating device (sparger system) was installed at the point of entry to the TSF distribution system to remove volatile trichloroethylene from TSF drinking water. Results from water samples at the wells and distribution system indicate that the aeration system is efficiently volatilizing trichloroethylene. Drinking water passes through the aeration system before reaching the distribution system. Since installation of the aeration system in 1988, drinking water samples from the TSF distribution system have generally not exceeded regulatory levels. During 1998, the TSF distribution system was in compliance.

Chlorinated drinking water systems are also monitored for total trihalomethanes (bromodichloromethane, bromoform, chloroform, and dibromochloromethane). The concentration of trihalomethanes in the Rifle Range distribution system in 1998 remained significantly below the reporting level. The concentration in water from the CFA distribution system averaged about $7.0 \mu \mathrm{g} / \mathrm{L}$ in 1998 , or 7 percent of the EPA maximum contaminant level of $100 \mu \mathrm{g} / \mathrm{L}$.

From 1992 through 1995 the then-incumbent INEEL M\&O contractor conducted a semiannual monitoring program for lead and copper levels in drinking water in accordance with EPA regulations (40 CFR 141.80-141.91). MCLs for copper and lead were not exceeded during this period. Monitoring for these constituents was repeated in 1998 in accordance with regulations.

Water from the production and potable wells at INTEC and other facilities were sampled and analyzed at least once in 1998 for nitrogen as nitrate, lead, and copper (Table 6-3). None of these constituents were above the EPA maximum contaminant levels or state of Idaho drinking water limits in 1998.
More detailed information and data will be included in the 1998 Environmental Monitoring Program Report for the Idaho National Engineering and Environmental Laboratory, INEEL/EXT-99-00305, due to be published in August 1999.

\section{Argonne National Laboratory-West (ANL-W)}

The drinking water system at ANL-W was sampled in 1998 in accordance with Safe Drinking Water Act implementing regulations for organics, inorganics, gross alpha and gross beta radioactivity, uranium, and radium. All parameters were well below applicable standards.

\section{Naval Reactors Facility (NRF)}

Drinking water samples were collected prior to entering the distribution system and monitored for volatile organic compounds, inorganic constituents, and water quality parameters. These were drawn from a sampling port immediately downstream from the NRF water softening treatment system. No volatile organic compounds were detected above minimum detection levels established for the analyses of these compounds. Concentrations of inorganic analytes and water quality parameters were all below regulatory limits.

With the assistance of USGS, groundwater monitoring continued around NRF (Figure 6-3).

Specifics regarding this monitoring are published in the NRF Environmental Monitoring Report for Calendar Year 1998.

\subsection{RADIOCHEMICAL MONITORING}

\section{USGS: Contaminant Plumes}

Historic waste disposal practices have produced localized plumes of radiochemical and chemical contaminants in the Snake River Plaın aquifer at the INEEL. The movements of the 
Table 6-2. Purgeable Organic Compounds in INEEL Drinking Water (1998)

\begin{tabular}{|c|c|c|c|c|c|c|c|c|c|c|c|c|}
\hline Well & Jan & Feb & Mar & Apr & May & Jun & Jul & Aug & Sep & Oct & Nov & Dec \\
\hline \multicolumn{13}{|c|}{ 1-1-Dichloroethylene (maximum contaminant level=7 $\mathrm{\mu g} / \mathrm{L}$ ) } \\
\hline CFA Dist. & $\ldots n^{\prime}$ & $\cdots$ & $\cdots$ & $\cdots$ & $-\cdots$ & --- & $\cdots$ & $0.3^{2 . b}$ & $\cdots$ & $\cdots$ & -- & $-\cdots$ \\
\hline \multicolumn{13}{|c|}{ Tetrachloroethylene (maximum contaminant level $=5 \mu \mathrm{g} / \mathrm{L}$ ) } \\
\hline RWMC Well & -- & 0.2 & --- & 0.3 & $-\cdots$ & 0.2 & 0.2 & $-\cdots$ & $\cdots$ & 0.3 & --- & 0.2 \\
\hline RWMC Dist. & -.. & 0.2 & -.- & -.- & --- & --- & --. & -.- & --- & 0.2 & --- & --- \\
\hline TSF Dist. & 0.4 & 0.4 & $--\cdot$ & 0.3 & 0.3 & --- & 0.4 & --- & -.- & 0.5 & -- & -.. \\
\hline TSF \# ! & -- & -- & $\ldots$ & 1.4 & -- & $\because$ & -- & --- & $\cdots$ & --- & --- & -.- \\
\hline TSF \#2 & 1.0 & --. & $\cdots$ & 0.6 & --- & $\cdots$ & -- & $\cdots$ & --- & $\cdots$ & --- & --- \\
\hline \multicolumn{13}{|c|}{ Trichloroethylene (maximum contaminant level $=5 \mu \mathrm{g} / \mathrm{L}$ ) } \\
\hline CFA Dist. & $\cdots$ & --- & -.- & 0.9 & -- & --- & $-\cdots$ & 0.2 & --- & $\cdots$ & -- & --- \\
\hline CFA\# 1 & $-\cdots$ & $\cdots$ & -.- & 0.4 & $\cdots$ & -.. & -- & --- & $\ldots$ & -.- & --- & $\cdots$ \\
\hline CFA\# 2 & $\cdots$ & $\cdots$ & $\cdots$ & 1.2 & $\cdots$ & $\cdots$ & -- & $\cdots$ & $\cdots$ & --- & -- & $\cdots$ \\
\hline RWMC Well & --- & 2.0 & -.- & 2.4 & --- & 2.4 & 2.0 & --- & $\cdots$ & 2.5 & --- & 1.9 \\
\hline RWMC Dist. & - & 1.7 & -.- & 1.5 & -- & 1.5 & 1.4 & -- & --- & 1.4 & -- & 1.2 \\
\hline TSF Dist. & 1.4 & 1.3 & $\ldots$ & 1.1 & -- & --- & 1.4 & -- & -- & 1.9 & --- & --- \\
\hline TSF \# 1 & $\ldots$ & -- & -.- & 4.6 & -- & --- & -- & -.. & $\cdots$ & $\ldots$ & --- & --- \\
\hline TSF \#2 & 3.4 & $\ldots$ & $\ldots$ & 1.8 & --- & --- & 2.0 & --- & --- & -- & $\ldots$ & --. \\
\hline \multicolumn{13}{|c|}{ Total Trihalomethane (maximum contaminant level=l00 $\mu \mathrm{g} / \mathrm{L}$ ) } \\
\hline CFA Dist. & -- & 5.7 & $\cdots$ & 8.4 & --- & $-\cdots$ & 8.4 & $+\cdots$ & $-\cdots$ & 5.5 & --. & $\ldots$ \\
\hline CPP Dist. & --- & 1.6 & $\cdots$ & 2.7 & --- &.-- & 11.3 & -- & -.. & 12.5 & --- & --- \\
\hline CTF. Dist. & -.- & 5.7 & -.. & 11.6 & $\cdots$ & $\cdots$ & 3.8 & -- & -.. & 5.6 &..- & --- \\
\hline PBF Dist. & --- & 5.3 & $\ldots$ & 5.7 &.-- & --- & 12.2 & --- & --- & 10.9 & -- & -.. \\
\hline TRA Dist. & --- & 0.1 & -.- & 0.3 & --- & $\ldots$ & 0.1 & --- & --- & 0.1 & --- & --- \\
\hline TSF Dist. &.- & 4.5 & ..- & 3.1 & --- & -.- & 2.8 & -.. & -.. & 3.8 & -.- & --- \\
\hline Rifle Range Dist. & $-\cdots$ & 0.1 & $\cdots$ & $\ldots$ & $\cdots$ & $--\cdot$ & 1.1 & --- & --- & 1.1 & --- & -.. \\
\hline \multicolumn{13}{|c|}{ Ethylbenzene (maximum contaminant level $=700 \mu \mathrm{g} / \mathrm{L}$ ) } \\
\hline CFA Dist. & $\cdots$ & --- & 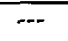 & 0.3 & $-\cdots$ & $\cdots$ & --- & --- & +-- & $\overline{---}$ & --- & --- \\
\hline CTF Dist. & -- & --- & $\ldots$ & 3.2 & --- & $\cdots$ & $\cdots$ & -- & --- & $\cdots$ & --- & --- \\
\hline PBF Dist. & $\cdots$ & --- & $\ldots$ & 0.5 & -- & --- & --- & 0.9 & $\cdots$ & $\ldots$ & --- & --- \\
\hline TSF Dist. & $\ldots$ & 2.3 & $\ldots$ & 1.6 & --. & $\ldots$ & 1.4 & -- & -.- & 0.6 & $\ldots$ & $\ldots$ \\
\hline \multicolumn{13}{|c|}{ Total Xylenes (maximum contaminant level $=10,000 \mu \mathrm{g} / \mathrm{L}$ ) } \\
\hline CFA Dist. & -- & $\cdots$ & $\cdots$ & 2.6 & $\cdots$ & $\cdots$ & --- & 0.6 & $\cdots$ & $\cdots$ & --- & --- \\
\hline CPP Dist. & --- & $\cdots$ & $\cdots$ & 0.2 & $\cdots$ & -- & $\cdots$ & 0.3 & $\cdots$ & $\cdots$ & -- & $\cdots$ \\
\hline CTF Dist. & -- & -- & ... & 15.0 & -- & -.. & --- & --- & --- & -- & --- & --- \\
\hline PBF Dist. & -- & 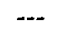 & $\cdots$ & 3.3 & $\cdots$ & -- & --- & 6.8 & $\cdots$ & $\ldots$ & --- & --- \\
\hline TSF Dist. & -- & 12.0 & $\cdots$ & 7.7 & $\cdots$ & $\cdots$ & 7.7 & -- & +- & 3.1 & --- & --- \\
\hline \multicolumn{13}{|c|}{ p-Dichlorobenzene (maximum contaminant level=75 $\mu \mathrm{g} / \mathrm{L}$ ) } \\
\hline EBR-1 Dist. & $-\ldots$ & $-\cdots$ & --- & 0.3 & --- & $\ldots$ & --- & --- & --- & $\ldots$ & -- & --- \\
\hline Rifle Range Dist. & -.. & --- & $\cdots$ & 0.1 & $\cdots$ & $-\cdot$ & --- & --- & --- & --- & -- & --- \\
\hline RWMC Dist. & - & --- & $\cdots$ & 0.1 & $-\cdots$ & $\cdots$ & 1.2 & --- & --- & 0.8 & $\ldots$ & 0.2 \\
\hline \multicolumn{13}{|c|}{ Carbon Tetrachloride (maximum contaminant level=5 $\mu \mathrm{g} / \mathrm{L}$ ) } \\
\hline CFA\# ] & 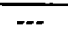 & $\cdots$ & $\ldots$ & 0.1 & --- & $\cdots$ & --- & -- & -.. & -.. & --- & --- \\
\hline RWMC Well & --- & 4.5 & $\cdots$ & 5.5 & --- & 5.1 & -- & --. & --- & 4.7 & $\ldots$ & 4.2 \\
\hline RWMC Dist. & $\cdots$ & 3.0 & $\cdots$ & 3.0 & $\cdots$ & 2.9 & 2.6 & $\ldots$ & -- & 2.7 & --- & 2.6 \\
\hline \multicolumn{13}{|c|}{ Toluene (maximum contaminant level $=1000 \mu \mathrm{g} / \mathrm{L}$ ) } \\
\hline CTF Dist. & $\ldots$ & -- & --- & 91 & $+\cdots$ & $\cdots$ & $\overline{--}$ & $-\infty$ & $\ldots$ & $\ldots$ & --- & --- \\
\hline TSF Dist. & $\ldots$ & 65 & -.- & 38 & $\ldots$ & $--\cdot$ & 26 & -- & $\ldots$ & 13 & --- & --- \\
\hline \multicolumn{13}{|c|}{$1,1,1$-Trichloroethane (maximum contaminant level $=200 \mu \mathrm{g} / \mathrm{L}$ ) } \\
\hline CFA\# 1 & --- & 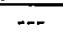 & $\cdots$ & 0.4 & --- & $\cdots$ & --- & --- & -- & --- & $-\overline{-}$ & --- \\
\hline CFA \# 2 & --- & -.- & ..- & 0.3 & $\ldots$ & $\cdots$ & --- & --- & --- & --. & --- & --- \\
\hline CFA Dist. & $\cdots$ & $\cdots$ & --- & 0.3 & -.. & --- & --- & 0.4 & -.. & $\ldots$ & $\cdots$ & $\ldots$ \\
\hline Main Gate Dist. & $-\cdots$ & $\cdots$ & -- & 1.2 & $\cdots$ & -- & --- & --- & --- & $\cdots$ & --- & --- \\
\hline RWMC Well & $-\cdots$ & 0.6 & $\cdots$ & 0.6 & $\cdots$ & 0.6 & 0.5 & $\cdots$ & $\cdots$ & 0.6 &.- & 0.5 \\
\hline RWMC Dist. & --- & 0.4 & $\cdots$ & 0.3 & --- & 0.3 & 0.3 & $\ldots$ & -.. & 0.3 & -- & 0.3 \\
\hline
\end{tabular}


Table 6-3. Inorganic Chemicals in INEEL Potable Production Wells (1998)

\begin{tabular}{|c|c|c|c|c|}
\hline Well & Date & Parameter & $\frac{\text { Concentration }}{(\mathrm{mg} / \mathrm{L})}$ & $\frac{\mathrm{MCL}}{(\mathrm{mg} / \mathrm{L})}$ \\
\hline TSF Dist. & $10 / 26$ & Nitrogen as Nitrate & 0.9 & 10 \\
\hline CFA Dist. & $10 / 26$ & Nitrogen as Nitrate & 3.6 & 10 \\
\hline CTF Dist. & $10 / 26$ & Nitrogen as Nitrate & 0.9 & 10 \\
\hline TRA Dist. & $10 / 26$ & Nitrogen as Nitrate & 1.1 & 10 \\
\hline PBF Dist. & $10 / 26$ & Nitrogen as Nitrate & 1.4 & 10 \\
\hline Main Gate Dist. & $10 / 26$ & Nitrogen as Nitrate & 0.8 & 10 \\
\hline EBR-1 Dist. & $10 / 26$ & Nitrogen as Nitrate & 0.5 & 10 \\
\hline Rifle Range Dist. & $10 / 26$ & Nitrogen as Nitrate & 1.5 & 10 \\
\hline RWMC Dist. & $10 / 26$ & Nitrogen as Nitrate & 1.4 & 10 \\
\hline CPP Dist. & $10 / 26$ & Nitrogen as Nitrate & 2.0 & 10 \\
\hline CFA Dist. & $07 / 28$ & Copper & 0.2 & 1.3 \\
\hline CFA Dist. & $07 / 29$ & Copper & 0.09 & 1.3 \\
\hline CFA Dist. & $11 / 10$ & Copper & 0.03 & 1.3 \\
\hline CPP Dist. & $07 / 28$ & Copper & 0.3 & 1.3 \\
\hline CPP Dist. & $11 / 09$ & Copper & 0.02 & 1.3 \\
\hline PBF Dist. & $07 / 28$ & Copper & 0.5 & 1.3 \\
\hline TAN Dist. & $07 / 27$ & Copper & 0.4 & 1.3 \\
\hline TAN Dist. & $07 / 28$ & Copper & 0.2 & 1.3 \\
\hline TRA Dist. & $07 / 28$ & Copper & 1.2 & 1.3 \\
\hline RWMC Dist. & $07 / 27$ & Copper & 0.2 & 1.3 \\
\hline CFA Dist. & $07 / 28$ & Lead & 0.004 & 0.015 \\
\hline CFA Dist. & $07 / 29$ & Lead & 0.002 & 0.015 \\
\hline CFA Dist. & $11 / 10$ & Lead & 0.006 & 0.015 \\
\hline CPP Dist. & $07 / 28$ & Lead & 0.004 & 0.015 \\
\hline CPP Dist. & $11 / 09$ & Lead & 0.002 & 0.015 \\
\hline PBF Dist. & $07 / 28$ & Lead & 0.006 & 0.015 \\
\hline TAN Dist. & $07 / 27$ & Lead & 0.004 & 0.015 \\
\hline TAN Dist. & $07 / 28$ & Lead & 0.001 & 0.015 \\
\hline
\end{tabular}

infiltration ponds, and since 1993 principally to lined evaporation ponds.

The configuration and extent of the tritium plume, based on the latest data, are shown in Figure 6-4 [Reference 6-1]. The area of the plume within the $0.5 \mathrm{pCi} / \mathrm{mL}$ contour line decreased from about 45 $\mathrm{mi}^{2}\left(115 \mathrm{~km}^{2}\right)$ in 1988 to about $40 \mathrm{mi}^{2}\left(100 \mathrm{~km}^{2}\right)$ in 1991. In 1995, the area was about the same as it was in 1991. Concentrations of tritium in the plume have generally decreased. The area of elevated concentrations near CFA may represent water originating at INTEC some years earlier when larger amounts of tritium were disposed, since there is no source of tritium contamination of ground water at CFA. Tritium concentrations in quarterly samples taken by the M\&O contractor in 1998 at wells at CFA are given in Table 6-4.

The tritium concentration in well 65 near TRA (Figure 6-2) decreased from $37.8 \pm 0.8$ $\mathrm{pCi} / \mathrm{mL}$ in 1991 to $21.2 \pm 0.9$

tritium and ${ }^{90} \mathrm{Sr}$ plumes have been of principal concern over the years.

The tritium plume has developed from the disposal of wastewater at the INEEL since the 1950s. About $31,750 \mathrm{Ci}$ of tritium have been discharged to wells and ponds since 1952. The main sources of tritium contamination of ground water have been the injection of wastewater through the INTEC disposal well and the discharge of wastewater to the infiltration ponds at the INTEC and TRA. Since 1984, wastewater has been discharged only to the
$\mathrm{pCi} / \mathrm{mL}$ in 1995; the tritium concentration in well 77 south of INTEC (Figure 6-2) decreased from $41.7 \pm 0.9 \mathrm{pCi} / \mathrm{mL}$ in 1991 to $25.1 \pm$ 1.0 in 1995. The EPA maximum contaminant level (MCL) for tritium in drinking water is 20 $\mathrm{pCi} / \mathrm{mL}$. These decreased tritium concentrations over the long term are primarily due to radioactive decay (tritium has a half-life of 12.3 years) and a decrease in tritium disposal rates. The average combined rate of tritium disposal at the TRA and INTEC during $1952-83$ was 910 $\mathrm{Ci} / \mathrm{yr}$; during 1984-91, $280 \mathrm{Ci} / \mathrm{yr}$; and during 1992-95, 107 Ci/yr. 


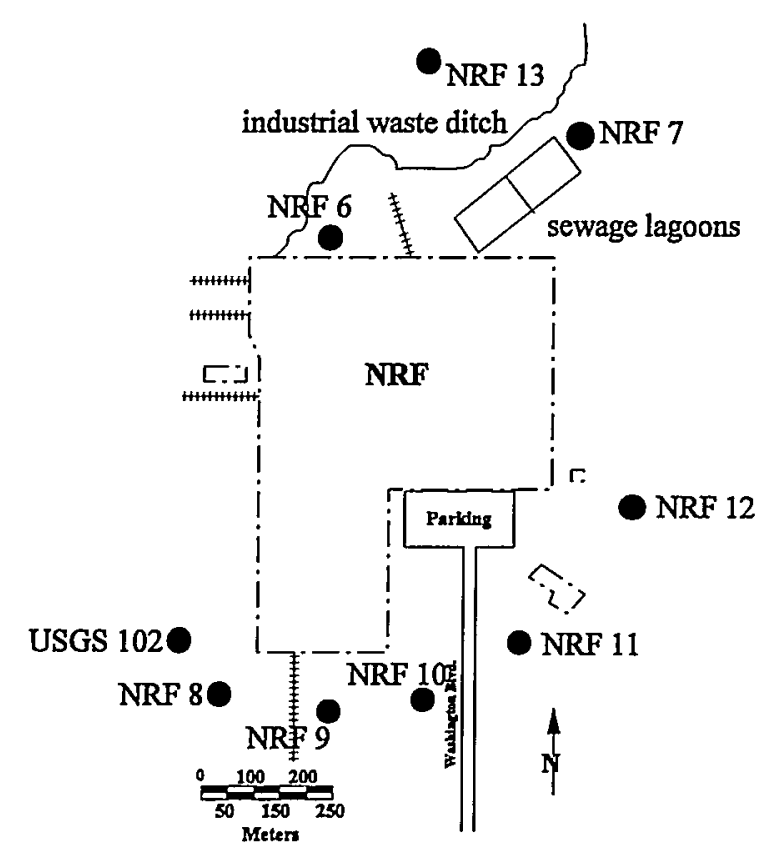

Figure 6-3. Monitoring Wells Around NRF

During 1952-95, the INEEL disposed of about $93 \mathrm{Ci}$ of ${ }^{90} \mathrm{Sr}$ at TRA and about $57 \mathrm{Ci}$ at INTEC. However, only at INTEC was an injection well used for disposal of some of the ${ }^{90} \mathrm{Sr}$ directly to the aquifer. This practice was discontinued in the 1980s. During 1992-95, the INEEL disposed of about $0.1 \mathrm{Ci}$ of ${ }^{90} \mathrm{Sr}$ to the TRA infiltration ponds. These ponds were replaced by hypalon-lined evaporation ponds in August 1993.

The configuration and extent of the ${ }^{90} \mathrm{Sr}$ contaminant plume, based on the latest data, are shown in Figure 6-5 [Reference 6-1]. The plume originates from the INTEC. No ${ }^{90} \mathrm{Sr}$ contaminant plume has been detected in the vicinity of TRA. At TRA, ${ }^{90} \mathrm{Sr}$ probably is retained in surficial sedimentary deposits and in interbeds, but is not intercepted by perched ground-water zones. All ${ }^{90} \mathrm{Sr}$ at TRA was disposed to infiltration ponds in contrast to the direct injection which occurred at the INTEC. The area of the ${ }^{90} \mathrm{Sr}$ contaminant plume is approximately the same as it was in 1991. Concentrations of ${ }^{90} \mathrm{Sr}$ in the wells have remained relatively constant since 1991 . The concentrations during 1992-95 ranged from
$2.6 \pm 0.7 \mathrm{pCi} / \mathrm{L}$ to $76 \pm 3 \mathrm{pCi} / \mathrm{L}$. The MCL for

${ }^{90} \mathrm{Sr}$ in drinking water is $8 \mathrm{pCi} / \mathrm{L}$.

Prior to $1989,{ }^{90} \mathrm{Sr}$ concentrations had been decreasing because of changes in waste disposal practices, radioactive decay, diffusion, dispersion, and dilution from natural groundwater recharge. The relatively constant ${ }^{90} \mathrm{Sr}$ concentrations in the wells sampled from 1992 to 1995 are thought due, in part, to a lack of recharge from the Big Lost River that would act to dilute the ${ }^{90} \mathrm{Sr}$. Also, an increase in the disposal of other chemicals into the INTEC infiltration ponds may have decreased the sorption, via ion-exchange, of ${ }^{90} \mathrm{Sr}$ on soil and rock surfaces, allowing more ${ }^{90} \mathrm{Sr}$ to exist in the liquid phase [Reference 6-1].

\section{M\&O Contractor}

Gross Alpha. Of the 59 onsite production well and distribution system samples analyzed for gross alpha in 1998, a total of seven samples contained activities above the minimum detectable concentration. The highest concentration obsenved was $7 \pm 2 \times 10^{-9} \mu \mathrm{Ci} / \mathrm{mL}$ in a sample collected on July 16 from the INTEC Distribution System. This value is 47 percent of the EPA MCL of $15 \times 10^{-9} \mu \mathrm{Ci} / \mathrm{mL}$ for gross alpha in drinking water.

According to USGS reports, alpha-emitting wastes $\left({ }^{238} \mathrm{Pu},{ }^{239 / 240} \mathrm{Pu}\right.$, and $\left.{ }^{241} \mathrm{Am}\right)$ from INEEL operations have not migrated far from their entrance into the aquifer near INTEC. All onsite drinking water wells lie outside the migration plumes for alpha-emitting nuclides.

Gross Beta. Of the 59 onsite production well samples analyzed for gross beta, six had gross beta activities above the minimum detectable concentration. All were within the range typically found for background concentrations from natural radioactivity in the Snake River Plain aquifer. The highest observed activity was $(9 \pm 2) \times 10^{-9} \mu \mathrm{Ci} / \mathrm{mL}$ in a sample from the CFA distribution system in February. This value is 18 percent of the EPA MCL of $50 \times 10^{-9} \mu \mathrm{Ci} / \mathrm{mL}$ for gross beta in drinking water. 
Tritium. Samples from five of the onsite production wells and three drinking water distribution systems that were routinely sampled in 1998 showed detectable concentrations of tritium in one or more samples (Table 6-4). Figure 6-6 shows 12 years of tritium data for two of the production wells and two distribution systems.

Strontium-90. Because of the presence of the localized plume of ${ }^{90} \mathrm{Sr}$ in the ground water near INTEC, sampling from several production wells at INTEC is routinely performed. While samples have historically contained detectable levels of ${ }^{90} \mathrm{Sr}$, none of the 1998 samples exhibited detectable concentrations of ${ }^{90} \mathrm{Sr}$ (the minimum detectable concentration was approximately $0.3 \times 10^{-9}$ $\mu \mathrm{Ci} / \mathrm{mL})$.

CFA Worker Dose. The potential effective dose equivalent to a worker at CFA from radioactivity in water was calculated. CFA was selected because tritium concentrations found in these wells were the highest of any drinking water wells. The 1998 calculation was based on:

- Mean tritium concentration for the CFA distribution system in 1998 as shown in Table 6-4.

- Data from a 1990-91 USGS study for ${ }^{129}$ ] using the accelerator mass spectrographic analytical technique that indicated water from CFA \#1 contained ${ }^{129}$ l at a concentration of
$.26 \pm 0.05) \times 10^{-9} \mu \mathrm{Ci} / \mathrm{mL}$ (the average of two samples) and water from CFA \#2 had a concentration of $(0.14 \pm 0.03) \times 10^{-9} \mu \mathrm{Ci} / \mathrm{mL}$ (also the average of two samples). For perspective, the proposed EPA drinking water standard for ${ }^{129}$ in drinking water is $21 \times 10^{-9}$ $\mu \mathrm{Ci} / \mathrm{mL}$.

- Water usage information for 1998 showing CFA \# 1 was used for approximately 44 percent of the drinking water and CFA \#2 was used for 56 percent of the drinking water.

For the 1998 dose calculation, the assumption was made that each worker's total water intake came from the CFA drinking water

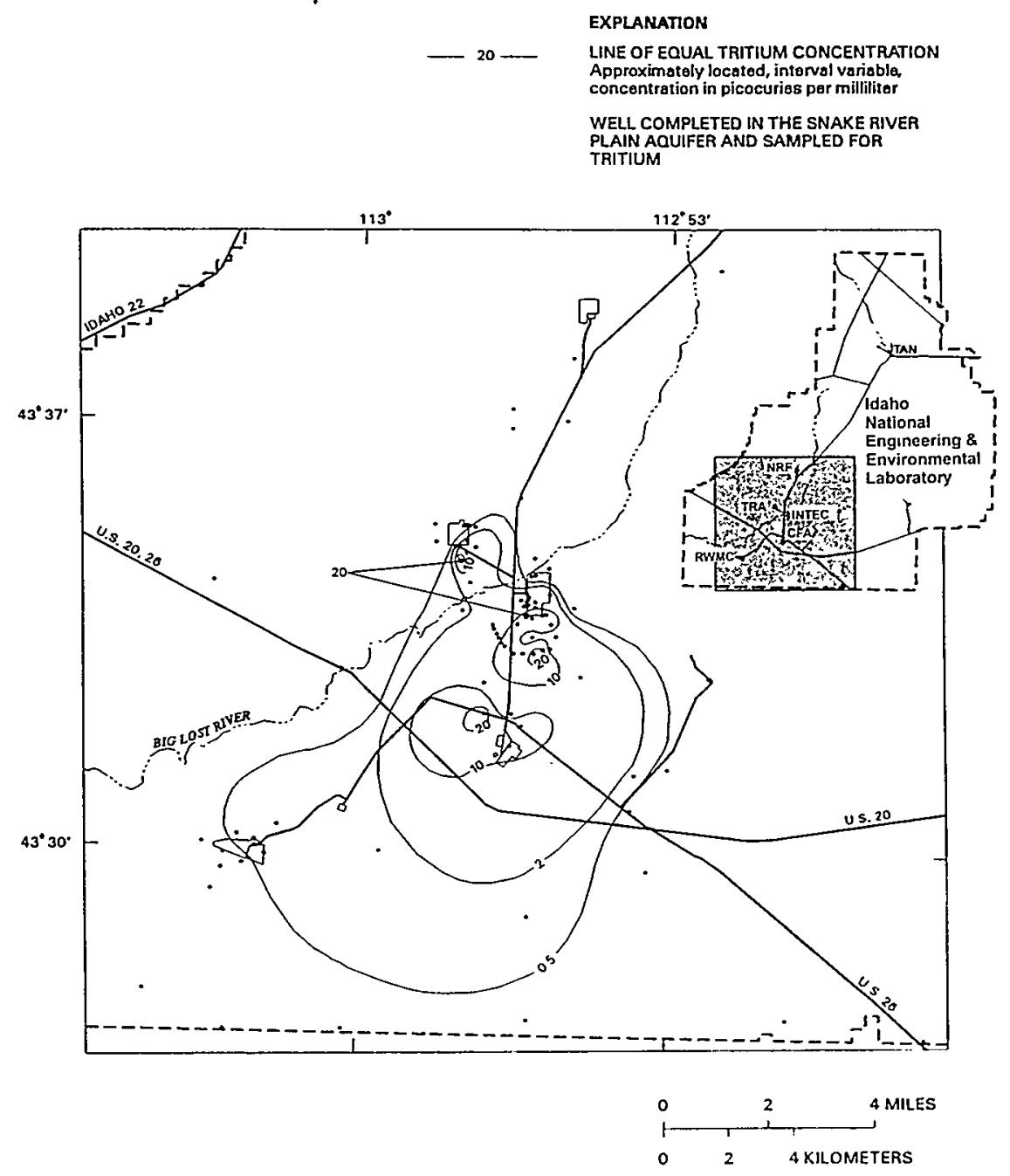

Figure 6-4. Distribution of Tritium in the Snake River Plain Aquifer on the INEEL (1995) 
Table 6-4. Tritium Concentrations in INEEL Production Wells and Distribution Systems (1998)

\begin{tabular}{|c|c|c|c|c|c|}
\hline \multirow[b]{2}{*}{ Well Code } & \multirow{2}{*}{$\begin{array}{c}\text { \# of } \\
\text { Samples }^{\text {a }}\end{array}$} & \multicolumn{3}{|c|}{$\begin{array}{l}\text { Trifium Concentration } \\
\left(\times 10^{-6} \mu \mathrm{Ci} / \mathrm{mL}\right)\end{array}$} & \multirow[b]{2}{*}{$\% M C L$} \\
\hline & & Minimum & Maximum & Mean & \\
\hline CFA Dist. & 4 & $10.1 \pm 0.7^{b}$ & $15.2 \pm 1.0$ & $11.8 \pm 0.8$ & 59 \\
\hline CFA \#1 & 3 & $11.1 \pm 0.7$ & $15.7 \pm 1.1^{\circ}$ & $12.9 \pm 0.7$ & 65 \\
\hline CFA \#2 & 4 & $9.7 \pm 0.6$ & $12.0 \pm 0.8$ & $10.8 \pm 0.7$ & 54 \\
\hline EBR-1 Dist. & 4 & $-0.03 \pm 0.1$ & $0.1 \pm 0.1$ & $0.01 \pm 0.1$ & 0.05 \\
\hline Rifle Range & 4 & $2.6 \pm 0.2$ & $3.0 \pm 0.2$ & $2.8 \pm 0.2$ & 14 \\
\hline RWMC Dist. & 4 & $1.3 \pm 0.1$ & $1.6 \pm 0.2$ & $1.4 \pm 0.2$ & 7 \\
\hline RWMC Well & 4 & $1.4 \pm 0.2$ & $1.5 \pm 0.2$ & $1.5 \pm 0.2$ & 8 \\
\hline INTEC Dist. & 4 & $-0.2 \pm 0.1$ & $0.2 \pm 0.1$ & $0.05 \pm 0.1$ & 0.25 \\
\hline INTEC Well \#4 & 4 & $-0.1 \pm 0.1$ & $0.5 \pm 0.1$ & $0.1 \pm 0.1$ & 0.5 \\
\hline INTEC Well \#5 & 4 & $-0.1 \pm 0.1$ & $0.1 \pm 0.1$ & $0.02 \pm 0.1$ & 0.1 \\
\hline Main Gate Dist. & 4 & $-0.2 \pm 0.1$ & $0.1 \pm 0.1$ & $-0.04 \pm 0.1$ & -- \\
\hline PBF Dist. & 4 & $-0.1 \pm 0.1$ & $0.004 \pm 0.1$ & $-0.05 \pm 0.1$ & -- \\
\hline TAN/CTF Dist. & 4 & $-0.1 \pm 0.1$ & $-0.03 \pm 0.1$ & $-0.05 \pm 0.1$ & -- \\
\hline TAN/TSF & 4 & $-0.1 \pm 0.1$ & $0.1 \pm 0.1$ & $-0.1 \pm 0.1$ & $--\cdot$ \\
\hline TRA Dist. & 4 & $-0.1 \pm 0.1$ & $0.03 \pm 0.1$ & $-0.02 \pm 0.1$ & $-\cdots$ \\
\hline $\begin{array}{l}\text { - Samples taken only } \\
\text { - Tritium concentrati } \\
\text { - EPA drinking water }\end{array}$ & $\begin{array}{l}\text { from wells in use } \\
\text { ion } \pm 25 \text {. } \\
M C L \text { (maximum } c\end{array}$ & $\begin{array}{l}\text { at collection time. } \\
\text { ontaminant level) fo }\end{array}$ & . & & \\
\hline
\end{tabular}

distribution system. This assumption over-estimates the dose because workers typically consume only about half their total intake during working hours and typically work only 240 days rather than 365 days per year. The estimated effective dose equivalent to a worker from consuming all drinking water at CFA during 1998 was 0.5 mrem, 13 percent of the EPA standard of four mrem for community drinking water systems.

\section{ANL-W}

During 1998, ANL-W analyzed one sample for gross alpha, gross beta, and tritium from the entrance to the drinking water distribution system in accordance with the Safe Drinking Water Act. The gross alpha concentration was $1.6 \mathrm{pCi} / \mathrm{L}$ (11 percent of the maximum contaminant level); the gross beta concentration was $5.3 \mathrm{pCi} / \mathrm{L}$ ( 11 percent of the maximum contaminant level). No detectable concentrations of tritium were reported.
ANL-W sampled its Industrial Waste Pond and Secondary Sanitary Lagoon monthly. The water samples were analyzed for gross alpha, gross beta, tritium, and gamma-emitting radionuclides. No gross alpha activity, gross beta activity, tritium, or gamma-emitting radionuclides were detected in either pond.

\section{NRF}

Ground water monitoring from NRF groundwater wells did not detect any gross alpha or gross beta activity in excess of natural background concentrations. 


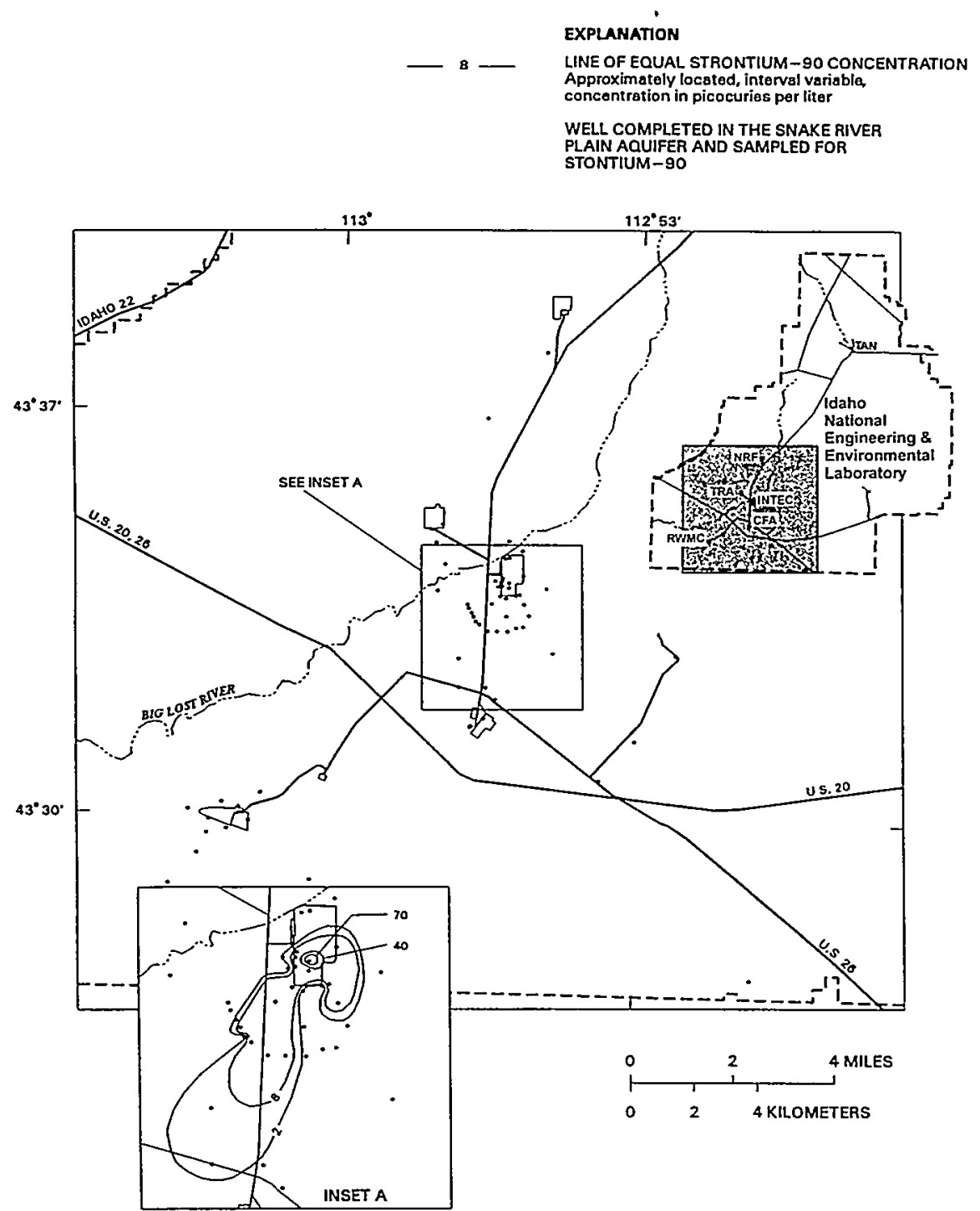

Figure 6-5. Distribution of ${ }^{90} \mathrm{Sr}$ in the Snake River Plain Aquifer on the INEEL (1995)

\subsection{BACTERIOLOGICAL MONITORING}

\section{M\&O Contractor}

Potable water at the INEEL was monitored for coliform bacteria quarterly or monthly by contractor personnel and analyzed by the $\mathrm{M} \& \mathrm{O}$ contractor Environmental Hygiene Laboratory. A total of 507 samples were collected at 12
INEEL facilities during 1998. No coliform bacteria were detected in any sample.

\section{NRF}

Drinking water samples were collected monthly and analyzed for the presence of coliform bacteria. Frequency and sample locations met the requirements of applicable state and federal regulations. No coliform bacteria 


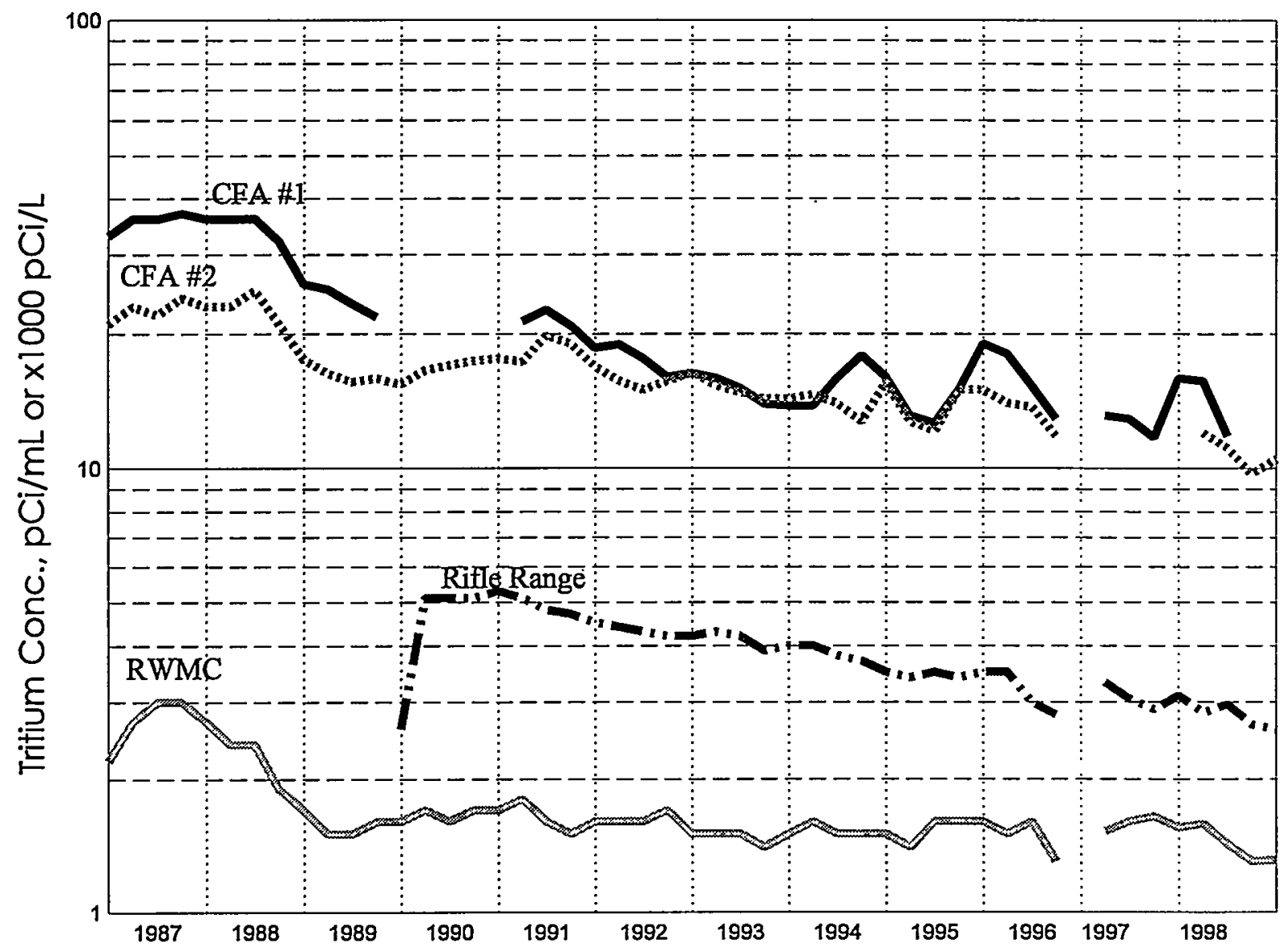

Figure 6.6. Tritium Concentrations in INEEL Production Wells and Distribution Systems (1987-1998)

were detected in the NRF drinking water supply system.

\section{ANL-W}

ANL-W conducted monthly bacteriological sampling, with analysis performed by the $M \& O$ contractor Environmental Hygiene Laboratory. No detections were found in 1998. 


\section{Chapter 7 \\ Effluent Monitoring}

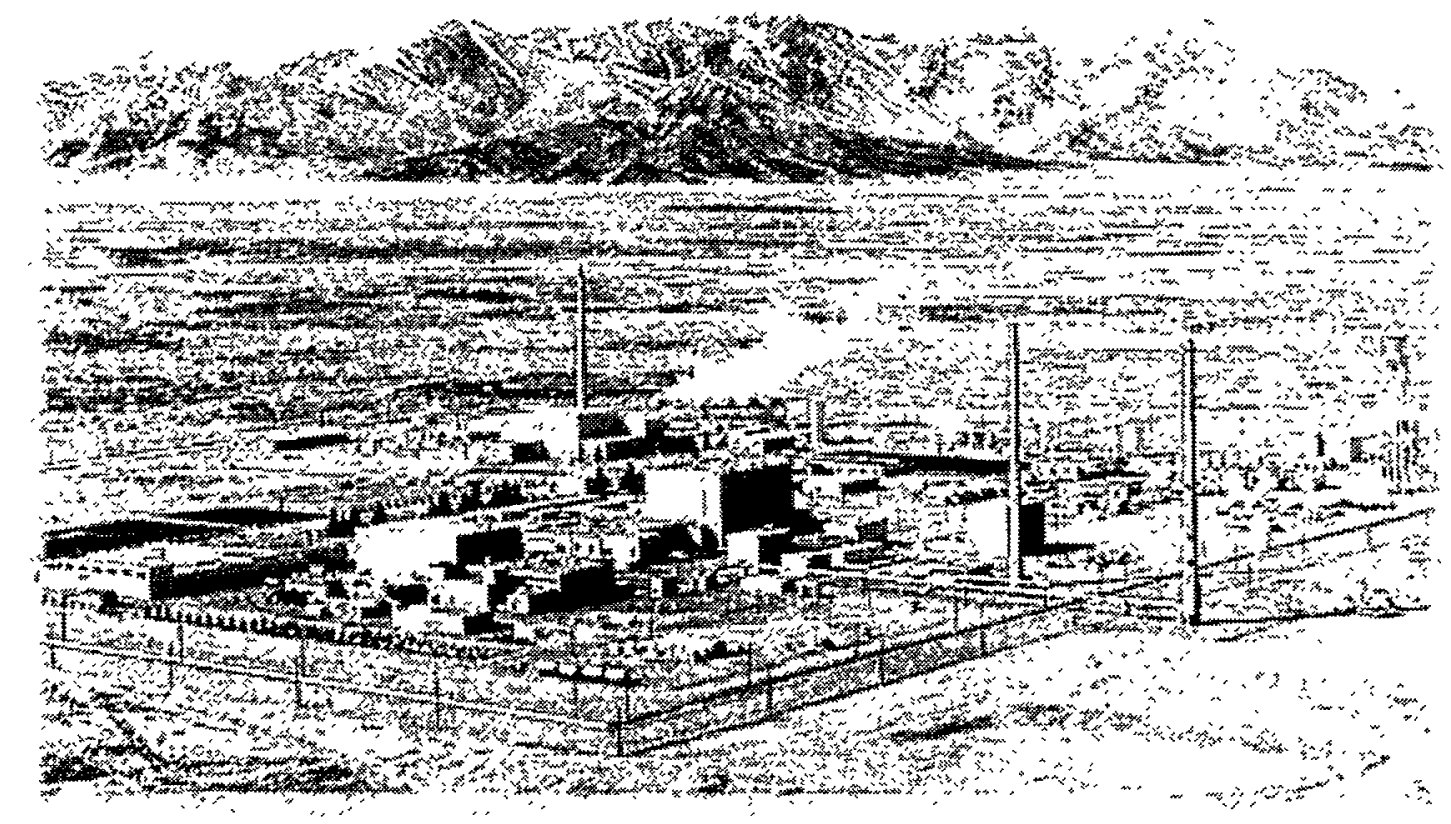





\section{EFFLUENT MONITORING}

\subsection{RADIOACTIVE EFFLUENTS}

\section{General Information}

Radionuclides released to the environment via airborne and liquid effluents were monitored during 1998 at potentially significant release sites as required by state and federal regulations. These sites included stacks and liquid effluent streams, monitored by INEEL contractors at the relevant facilities. Monitoring results were reported to the Radioactive Waste Management Information System (RWMIS) administered by the M\&O contractor. Effluent information from the RWMIS is used to produce annual reports summarizing effluent monitoring by month, facility, and radionuclide.

\section{Airborne Effluents}

During 1998, an estimated 5,995 Curies (Ci) of radioactivity were released to the atmosphere from all INEEL sources [Reference 7-1]. Argonne National Laboratory-West (ANL-W) accounted for 79 percent of the total, with the Test Reactor Area (TRA) contributing most of the remaining 21 percent (Table 7-1). Over 98 percent of the radioactive effluent was in the form of noble gases, elements from Group 8 on the periodic table of the elements. The primary exposure concern for noble gases is external, as these are generally not transported through food chains and do not concentrate in biological tissues [Reference 7-2].

Year-to-year fluctuations in airborne radioactive effluent releases are dependent on which processes are active at INEEL facilities. The totals for 1997 and 1998 are higher than the annual totals for 1994-1996 (Figure 7-1). This is due primarily to an increase in releases of ${ }^{85} \mathrm{Kr}$ from ANL-W as part of a spent fuel treatment project, the Electrometallurgical Treatment Research and Demonstration Project in the Fuel Conditioning Facility. Although airborne releases during 1998 are the highest of the past five years, they are still considerably less than the annual totals throughout the 1980 s.

\section{Liquid Effluents}

Table $7-2$ summarizes the radioactive liquid effluents released onsite during 1998. Nearly all of the radioactive liquid effluent was released from TRA into two hypalon plasticlined evaporation ponds, in use since August 1993. These ponds senve to prevent contaminant percolation into the ground, thus minimizing contaminant dispersal. No radioactive liquid effluent was released to the offsite environment from INEEL facilities during 1998. Routine injections of radioactive liquid effluents into the Snake River Plain aquifer ceased in 1984.

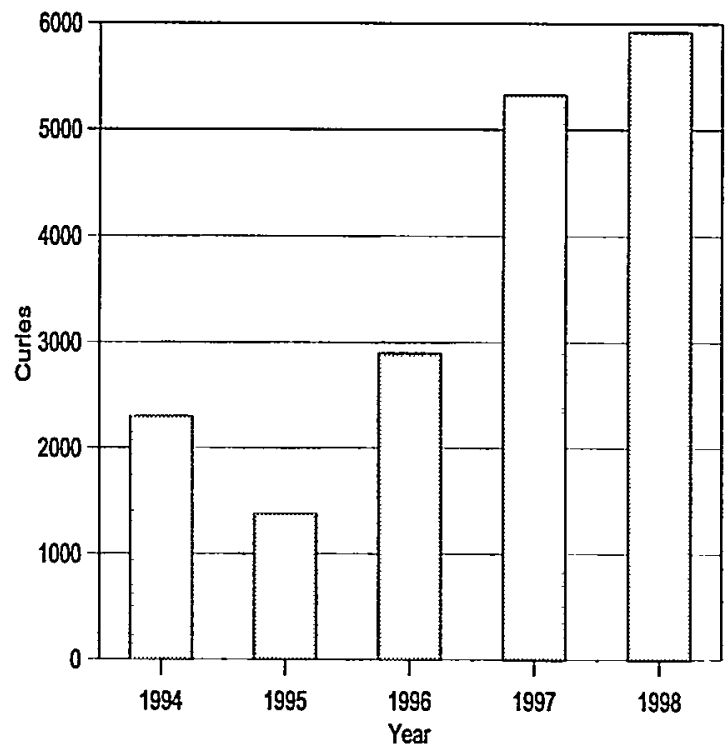

Figure 7-1. INEEL Airborne Radioactive Effluent 
Table 7-1. Radionuclide Composition of INEEL Airborne Effluents (1998)

Airborne Effluent $(\mathrm{Ci})$

\begin{tabular}{|c|c|c|c|c|c|c|c|}
\hline $\begin{array}{c}\text { Effluent }{ }^{b} \\
\text { Iype }\end{array}$ & $\begin{array}{l}\text { Radio- } \\
\text { nuclide }\end{array}$ & Half-life & ANL-W & INTEC & $\underline{N R F}$ & IRA & Total \\
\hline \multirow[t]{5}{*}{ Noble Gases } & ${ }^{85} \mathrm{Kr}$ & $10.7 \mathrm{yr}$ & 4,687 & $\overline{--}$ & $\overrightarrow{0.30}$ & $\overline{--}$ & $\overline{4,687}$ \\
\hline & ${ }^{41} \mathrm{Ar}$ & $1.83 \mathrm{~h}$ & 2.3 & - & -- & 1,172 & 1,175 \\
\hline & ${ }^{135} \mathrm{Xe}$ & $9.10 \mathrm{~h}$ & -- & -- & -- & 18.5 & 18.5 \\
\hline & ${ }^{133} \mathrm{Xe}$ & $5.25 d$ & -- & -. & -- & 7.8 & 7.8 \\
\hline & ${ }^{85 m} \mathrm{Kr}$ & $4.48 h$ & -- & -. & -. & 1.5 & 1.5 \\
\hline \multirow[t]{11}{*}{ Particulates } & ${ }^{88} \mathrm{Rb}$ & $17.7 \mathrm{~min}$ & -- & -- & -. & 1.1 & 1.1 \\
\hline & ${ }^{138} \mathrm{Cs}$ & $32.2 \mathrm{~min}$ & .. & -- & -. & $5.0 \times 10^{-2}$ & $5.0 \times 10^{-2}$ \\
\hline & ${ }^{24} \mathrm{Na}$ & $15.6 \mathrm{~h}$ & -- & -- & - & $1.3 \times 10^{-2}$ & $1.3 \times 10^{-2}$ \\
\hline & ${ }^{234} \mathrm{U}$ & $246,000 \mathrm{yr}$ & -- & .. & -- & -- & $5.0 \times 10^{-3}$ \\
\hline & ${ }^{51} \mathrm{Cr}$ & $27.8 d$ & -. & -- & -- & $3.7 \times 10^{-3}$ & $3.7 \times 10^{3}$ \\
\hline & ${ }^{99 \mathrm{~m}} \mathrm{TC}$ & $6.01 \mathrm{~h}$ & -- & -. & -. & $1.4 \times 10^{-3}$ & $1.4 \times 10^{-3}$ \\
\hline & ${ }^{137} \mathrm{Cs}$ & $30.2 \mathrm{yr}$ & .. & $1.3 \times 10^{-3}$ & -- & $1.4 \times 10^{-5}$ & $1.3 \times 10^{-3}$ \\
\hline & ${ }^{125} \mathrm{Sb}$ & $2.73 \mathrm{yr}$ & -- & $1.3 \times 10^{-4}$ & -- & -. & $1.3 \times 10^{-4}$ \\
\hline & ${ }^{90} \mathrm{Sr}+\mathrm{D}^{c}$ & $=28.6 \mathrm{yr}$ & -- & $3.1 \times 10^{-4}$ & -- & $2.6 \times 10^{-6}$ & $3.1 \times 10^{-4}$ \\
\hline & ${ }^{238} \mathrm{Pu}$ & $87.7 \mathrm{yr}$ & -- & $5.0 \times 10^{-6}$ & - & -. & $5.0 \times 10^{-6}$ \\
\hline & ${ }^{239} \mathrm{Pu}$ & $2.4 \times 10^{4} \mathrm{yr}$ & -- & $5.3 \times 10^{-7}$ & -. & -- & $5.3 \times 10^{-7}$ \\
\hline \multirow{6}{*}{$\begin{array}{l}\text { Tritium, }{ }^{14} \mathrm{C} \\
\text { and lodine } \\
\text { lsotopes }\end{array}$} & ${ }^{3} \mathrm{H}$ & $12.3 \mathrm{yr}$ & 30 & 74 & $4.9 \times 10^{-2}$ & -- & 104 \\
\hline & ${ }^{14} \mathrm{C}$ & $5,700 \mathrm{yr}$ & -- & -- & 0.80 & -- & 0.80 \\
\hline & 129 & $1.6 \times 10^{7} \mathrm{yr}$ & .- & $1.8 \times 10^{-2}$ & -. & -. & $1.8 \times 10^{2}$ \\
\hline & $133 \mid$ & $20.8 \mathrm{~h}$ & -- & -. & - & $1.5 \times 10^{-3}$ & $1.5 \times 10^{-3}$ \\
\hline & 130 & $6.57 \mathrm{~h}$ & -- & -- & -. & $8.2 \times 10^{-4}$ & $8.2 \times 10^{4}$ \\
\hline & 1311 & $8.04 d$ & -. & -- & $1.0 \times 10^{-b}$ & $6.6 \times 10^{-4}$ & $6.7 \times 10^{-4}$ \\
\hline \multirow{2}{*}{\multicolumn{2}{|c|}{$\begin{array}{l}\text { All others } \\
\text { Totals d }\end{array}$}} & -- & $4.8 \times 10^{-5}$ & $4.8 \times 10^{-3}$ & $3.1 \times 10^{-4}$ & $2.2 \times 10^{-3}$ & $2.7 \times 10^{-3}$ \\
\hline & & -- & 4,719 & 74 & 1.1 & 1,201 & 5,995 \\
\hline \multicolumn{8}{|c|}{$\begin{array}{l}\text { Radioactive release information provided by the report } 1998 \text { INEEL National Emissions Standard } \\
\text { for Hazardous Air Pollutants - Radionuclides, DOE/ID-10342(98), June } 1999 .\end{array}$} \\
\hline \multicolumn{8}{|c|}{$\begin{array}{l}\text { The table includes all radionuclides with total releases greater than } 1 \times 10^{-3} \mathrm{Ci}\left(1 \times 10^{-4} \text { for isotopes }\right. \\
\text { of iodine). Some radionuclides of special concern }\left({ }^{125} \mathrm{Sb},{ }^{90} \mathrm{Sr},{ }^{137} \mathrm{Cs} \text {, and } \mathrm{Pu}\right) \text { are also included. } \\
\text { Values are not corrected for decay after release. }\end{array}$} \\
\hline \multicolumn{8}{|c|}{ c " $+D$ " indicates parent-daughter equilibrium assumed. } \\
\hline \multicolumn{8}{|c|}{ d Rounded totals include small amounts from facilities not listed. } \\
\hline
\end{tabular}

\subsection{NONRADIOACTIVE EFFLUENTS}

\section{Airborne Effluents}

Sitewide Air Emission Inventory. Non-radioactive airborne effluents are monitored at relevant INEEL facilities. Pollutants of particular interest include two oxides of nitrogen, nitrogen oxide (NO) and nitrogen dioxide $\left(\mathrm{NO}_{2}\right)$, which are collectively referred to as $\mathrm{NO}_{x}$. Other substances monitored include sulfur oxides, (primarily in the form of sulfur dioxide $\mathrm{SO}_{2}$ ), carbon monoxide, volatile organic compounds, and $\mathrm{PM}_{10}$, particulates greater than 10 micrometers in diameter.

The M\&O contractor publishes the Air Emission Inventory for the INEEL annually ([Reference 7-3], a compilation of emissions from sources at all facilities. 
Table 7-2. Radionuclide Composition of Liquid Effluents Released Onsite (1998) a

\begin{tabular}{|c|c|c|c|c|}
\hline \multirow[b]{2}{*}{ Radionuclide } & \multirow[b]{2}{*}{ Half-Life } & \multicolumn{3}{|c|}{ Liquid Effluent (Ci) } \\
\hline & & INTEC & TRA & Total \\
\hline${ }^{3} \mathrm{H}$ & $12.3 \mathrm{yr}$ & -- & 75.3 & 75.3 \\
\hline${ }^{51} \mathrm{Cr}$ & $27.8 d$ & -. & 2.3 & 2.3 \\
\hline${ }^{60} \mathrm{Co}$ & $5.27 \mathrm{yr}$ & -- & 0.24 & 0.24 \\
\hline${ }^{181} \mathrm{Hf}$ & $42.4 d$ & -- & $5.9 \times 10^{-2}$ & $5.9 \times 10^{-2}$ \\
\hline${ }^{95} \mathrm{Zr}$ & $35.0 d$ & - & $3.5 \times 10^{-2}$ & $3.5 \times 10^{-2}$ \\
\hline${ }^{24} \mathrm{Na}$ & $15.0 \mathrm{~h}$ & -- & $2.7 \times 10^{-2}$ & $2.7 \times 10^{.2}$ \\
\hline${ }^{95} \mathrm{Nb}$ & $64.0 \mathrm{~d}$ & -- & $1.7 \times 10^{-2}$ & $1.7 \times 10^{-2}$ \\
\hline${ }^{90} \mathrm{Sr}$ & $28.6 \mathrm{yr}$ & $1.1 \times 10^{-2}$ & $2.5 \times 10^{-3}$ & $1.4 \times 10^{-3}$ \\
\hline${ }^{103} R u$ & $39.3 d$ & -- & $1.2 \times 10^{-2}$ & $1.2 \times 10^{-2}$ \\
\hline All Others & -- & -- & 0.49 & 0.49 \\
\hline Totals ${ }^{\circ}$ & -- & $1.1 \times 10^{-2}$ & 78.5 & 78.5 \\
\hline
\end{tabular}

Argonne National Laboratory-West (ANL-W). Emissions from the Experimental Breeder Reactor II Auxiliary Boilers do not require continuous monitoring because they are below the state of Idaho's 250 million BTU/hour emission limit. Monitoring occurs monthly with a portable stack emission monitor as an efficiency check and to ensure $\mathrm{NO}_{\mathrm{x}}$ and $\mathrm{SO}_{2}$ emissions are below state-imposed standards. During 1998 , the $\mathrm{NO}_{\mathrm{x}}$ emissions ranged from 11 to $240 \mathrm{mg} / \mathrm{m}^{3}$ ( 6 to 127 parts per million) and $\mathrm{SO}_{2}$ emissions ranged from 0 to $88 \mathrm{mg} / \mathrm{m}^{3}$ ( 0 to 33 parts per million).

\section{Liquid Effluents}

General Information. In 1986, a Non-radiological Liquid Effluent Monitoring Program was instituted to provide environmental monitoring for non-radioactive parameters and pollutants in liquid wastes generated by INEEL facilities.

Non-radioactive liquid effluents are disposed primarily to the following areas on the INEEL: an industrial waste ditch and evaporative sewage lagoon at NRF; lined sewage lagoons at the SMC; seepage ponds at the TSF, TRA, INTEC, and WRRTF; an industrial waste pond at ANL-W; and sewage treatment facilities at various locations. Injection wells and the Big Lost
River are not used as repositories for any liquid wastes, except for storm water runoff.

Argonne National Laboratory-West. During 1998, the Industrial Waste Pond at ANL-W was monitored for iron, sodium, mercury, chloride, fluoride, sulfate, phosphate, temperature, dissolved oxygen, specific conductance, turbidity, and $\mathrm{pH}$. The Secondary Sanitary Lagoon was monitored for biological oxygen demand, total suspended solids, dissolved oxygen, specific conductance, turbidity, temperature, iron, sodium, chloride, fluoride, sulfate, and $\mathrm{pH}$. All parameters for both ponds were well below applicable standards. Additional analyses of sanitary wastewater were performed before, during, and after waste water application. Land application was necessary to lower the level in the pond to prevent the water from topping the berm surrounding it.

\section{Idaho Nuclear Technology and Engineering} Center (INTEC). Liquid effluent from INTEC, discharged to the percolation ponds since 1995 under a Waste Water Land Application Permit, consists primarily of cooling water from facility operations. Monitoring results are presented in Table 7-3. During 1998, measured concentrations for each parameter were below levels that would define the effluent as a hazardous waste stream. 
Table 7-3. INTEC Service Waste Inorganic Monitoring Data (1998)

\begin{tabular}{|c|c|c|c|c|c|c|c|c|c|c|c|c|c|}
\hline \multirow[b]{2}{*}{ Parameter ${ }^{a}$} & \multirow[b]{2}{*}{ Jan } & \multirow[b]{2}{*}{ Feb } & \multirow[b]{2}{*}{ Mar } & \multirow[b]{2}{*}{ Apr } & \multirow[b]{2}{*}{ May } & \multirow[b]{2}{*}{ Jun } & \multirow[b]{2}{*}{ Jul } & \multirow[b]{2}{*}{ Aug } & \multirow[b]{2}{*}{ Sep } & \multirow[b]{2}{*}{ Oct } & \multirow[b]{2}{*}{ Nov } & \multicolumn{2}{|c|}{ Toxicity } \\
\hline & & & & & & & & & & & & Dec & $\underline{\text { Limif }}$ \\
\hline Aluminum & $\overline{<\left.d\right|^{b}}$ & $\overline{<d l}$ & $\overline{c d l}$ & $\overline{<d l}$ & $\overline{<d l}$ & $\overline{<d l}$ & $\overline{<d l}$ & $\overline{<d l}$ & $\overline{<d l}$ & $\overline{<d l}$ & $\overline{<d l}$ & $\overline{<d l}$ & $N / A$ \\
\hline Arsenic & $<d l$ & $<d l$ & $<d l$ & $<d l$ & $<d l$ & $<d l$ & 0.003 & $<d l$ & $<d l$ & $<d l$ & $<d l$ & $<d \mid$ & 5 \\
\hline Barium & 0.08 & 0.07 & 0.08 & 0.09 & 0.05 & 0.09 & 0.09 & 0.08 & 0.09 & 0.05 & 0.08 & 0.07 & $N / A$ \\
\hline Cadmium & $<d l$ & $<d l$ & $<d l$ & $<d l$ & $<d l$ & $<d l$ & $<d l$ & $<d l$ & $<d l$ & $<d l$ & $<d l$ & $<d l$ & 1 \\
\hline Chromium & 0.004 & 0.005 & $<d l$ & $<d l$ & $<d l$ & 0.004 & $<d l$ & $<d l$ & $<d l$ & $<d l$ & $<$ dl & 0.005 & 5 \\
\hline Copper & 0.006 & 0.007 & 0.012 & 0.006 & $<d l$ & $<d l$ & $<d l$ & $<d l$ & $<d l$ & $<d l$ & $<d l$ & 0.006 & $N / A$ \\
\hline Lead & $<d l$ & $<d l$ & $<$ dl & $<d l$ & $<d l$ & $<d \mid$ & $<$ dl & $<d$ & $<d l$ & $<d l$ & $<$ dl & $<d l$ & 5 \\
\hline Mercury & $<d l$ & $<d l$ & $<d l$ & $<d l$ & $<d l$ & $<d l$ & 0.0002 & $<d l$ & $<d l$ & $<d \mid$ & $<$ dl & $<d \mid$ & 0.2 \\
\hline Selenium & $<d l$ & $<d l$ & $<d l$ & $<d l$ & $<d l$ & $<d l$ & 0.004 & $<d l$ & $<d l$ & $<d l$ & $<d l$ & $<d \mid$ & 1 \\
\hline Silver & $<d l$ & $<d l$ & $<d l$ & $<d l$ & $<d l$ & $<d l$ & $<d l$ & $<d l$ & $<d l$ & $<d \mid$ & $<d l$ & $<d \mid$ & 5 \\
\hline Sodium & 150 & 139 & 108 & 109 & 80 & 116 & 123 & 120 & 124 & 91 & 107 & 128 & $N / A$ \\
\hline Chloride & 238 & 213 & 164 & 178 & 96 & 195 & 218 & 182 & 242 & 100 & 176 & 202 & $N / A$ \\
\hline Fluoride & 0.24 & 0.24 & 0.27 & 0.22 & 0.23 & 0.26 & 0.25 & 0.25 & 0.31 & 0.31 & $<d l$ & 0.35 & N/A \\
\hline Iron & 0.04 & $<d l$ & $<d l$ & $<d l$ & 0.005 & $<d l$ & $<$ dl & $<d l$ & $<d l$ & $<d l$ & $<d l$ & $<d l$ & N/A \\
\hline Manganese & 0.002 & 0.0013 & 0.002 & 0.0013 & 0.00080 & 0.0008 & 0.0008 & $<d l$ & $<d l$ & $0.0011 \mathrm{C}$ & 0.0009 & 0.0010 & $N / A$ \\
\hline Phosphate & $<d l$ & $<d l$ & $<d l$ & $<d l$ & 0.06 & $<d l$ & $<d l$ & $<d l$ & $<d l$ & $<d l$ & $<d l$ & $<d l$ & N/A \\
\hline Sulfate & 27 & 27 & 42 & 91 & 37 & 39 & 37 & 53 & 32 & 40 & 38 & 27 & $N / A$ \\
\hline TDS ${ }^{\circ}$ & 610 & 582 & 480 & 592 & 372 & 551 & 555 & 556 & 640 & 385 & 531 & 553 & N/A \\
\hline $\mathrm{pH}$ & 8.5 & 8.1 & 8.3 & 8.2 & 6.6 & 8.1 & 8.2 & 8.1 & $-^{d}$ & 8.1 & -- & 8.2 & $2-12.5$ \\
\hline Conductivity & 697 & 1050 & 921 & 1030 & 679 & 1000 & 1040 & 984 & 1127 & 683 & 950 & 1025 & $N / A$ \\
\hline Nitrate & 0.99 & 1.1 & 1.1 & 0.97 & 0.98 & 2.6 & 0.93 & 0.94 & 0.90 & 0.96 & 0.89 & 0.92 & $N / A$ \\
\hline Nitrite & $<d l$ & $<d l$ & $<d l$ & $<d l$ & $<d l$ & $<d l$ & $<d l$ & $<d l$ & 0.08 & $<d l$ & $<d l$ & $<d l$ & $N / A$ \\
\hline$T K N^{e}$ & 0.15 & $<d l$ & 0.13 & 0.11 & $<d l$ & $<$ dl & $<d l$ & 0.14 & $<d l$ & 0.17 & 0.14 & $<d l$ & $N / A$ \\
\hline
\end{tabular}

* Concentration reported in $\mathrm{mg} / \mathrm{L}$ except conductivity ( $\mu S$ ) and $\mathrm{pH}$ (no units).

b <dl indicates concentration was below detection limit.

- TDS=Total dissolved solids.

A A dash (-) indicates data were judged unusable during validation.

- TKN=Total Kjeldahl Nitrogen.

Test Reactor Area (TRA). Non-radioactive liquid effluents are discharged from TRA into three types of ponds: the Cold Waste Pond, the the Chemical Waste Pond, and two sewage lagoons. The Cold Waste Pond receives primarily secondary cooling water from the Advanced Test Reactor. Table 7-4 summarizes the nonradiological monitoring data for effluents released into the Cold Waste Pond from TRA during 1998 [Reference 7-4]. The Chemical Waste Pond receives neutralized water from chemical treatment processes at the TRA demineralizer facility.

Naval Reactors Facility (NRF). Liquid effluent monitoring confirmed all discharges in 1998 were controlled in accordance with applicable federal and state laws. Specifics regarding this monitoring are published in the
NRF Environmental Monitoring Report for Calendar Year 1998. 
Table 7-4. TRA Liquid Effluent Inorganic Moniłoring Data (1998)

\begin{tabular}{|c|c|c|c|c|c|}
\hline \multirow[b]{2}{*}{ Parameter $^{\alpha}$} & \multicolumn{5}{|c|}{ Concentration } \\
\hline & January & March & August & December & $\frac{\text { Toxicity }}{\text { Limit }^{b}}$ \\
\hline Conductivity & 344 & 186 & 1179 & 1021 & -.. \\
\hline $\mathrm{pH}$ & 8.4 & 7.9 & 7.9 & 7.0 & 2 to 12.5 \\
\hline Total Dissolved Solids & 480 & 240 & 830 & 750 & -.. \\
\hline Chloride lon & 19 & 16 & 31 & 32 & --- \\
\hline Fluoride lon & 0.25 & $<\mathrm{dl}^{c}$ & $<d l$ & $<d l$ & $\ldots$ \\
\hline Total Nitrogen & 1.5 & 1.0 & 9.6 & 2.5 & $\ldots$ \\
\hline Sulfate & 147 & 23 & 390 & 360 & -.. \\
\hline Silver & 0.005 & $<d l$ & $<d l$ & $<d l$ & 5 \\
\hline Aluminum & $N A^{d}$ & $<d l$ & $<d l$ & $<d l$ & $\cdots$ \\
\hline Arsenic & 0.006 & $<d l$ & 0.010 & $<d l$ & 5 \\
\hline Barium & 0.07 & $<d l$ & 0.12 & 0.10 & 100 \\
\hline Beryllium & $<d l$ & $<d l$ & $<d l$ & $<d l$ & -.- \\
\hline Calcium & 89 & 51 & 140 & 130 & -.. \\
\hline Cadmium & $<d l$ & $<d l$ & $<d l$ & $<d l$ & 1 \\
\hline Cobalt & $<d l$ & $<d l$ & $<d l$ & $<d l$ & --- \\
\hline Chromium & 0.008 & $<d l$ & $<d l$ & $<d l$ & 5 \\
\hline Copper & 0.009 & $<d l$ & 0.010 & $<d l$ & $\ldots$ \\
\hline Iron & 0.02 & $<d l$ & $<d l$ & $<d l$ & --- \\
\hline Mercury & $<d l$ & $<d l$ & $<d l$ & $<d l$ & 0.2 \\
\hline Potassium & 5.0 & 2.1 & 11 & 10 & --- \\
\hline Magnesium & 31 & 19 & 51 & 45 & --- \\
\hline Manganese & 0.0011 & $<d l$ & $<d l$ & $<d l$ & -.. \\
\hline Sodium & 15 & 9 & 29 & 26 & -- \\
\hline Nickel & 0.0014 & $<d l$ & $<d l$ & $<d l$ & -- \\
\hline Lead & $<d l$ & $<d l$ & $<d l$ & $<d l$ & 5 \\
\hline Antimony & $<d l$ & $<d l$ & $<d l$ & $<d l$ & $-\ldots$ \\
\hline Selenium & 0.002 & $<d l$ & 0.007 & $<d l$ & 1 \\
\hline Vanadium & $N A$ & $<d \mid$ & 0.011 & 0.011 & $\cdots$ \\
\hline Thallium & $<d l$ & $<d l$ & $<d l$ & $<d l$ & --- \\
\hline Zinc & 0.009 & $<d l$ & $<d l$ & $<d l$ & $\ldots$ \\
\hline \multicolumn{6}{|c|}{ Concentrations in $m g / L$ except conductivity $(\mu S)$ and pH (no units). } \\
\hline \multicolumn{6}{|c|}{$\begin{array}{l}\text { - EPA maximum concentration of contaminants for the toxicity characteristic is from } 40 \text { CFR } 261.24 \text {. A dash (---) in } \\
\text { this column means no limit has been established. }\end{array}$} \\
\hline \multicolumn{6}{|c|}{$=<d l$ indicates concentration below the detection limit. } \\
\hline \multicolumn{6}{|c|}{ d NA means no analysis performed for this sampling event. } \\
\hline
\end{tabular}




\section{Chapter 8 \\ Dose to the Public}

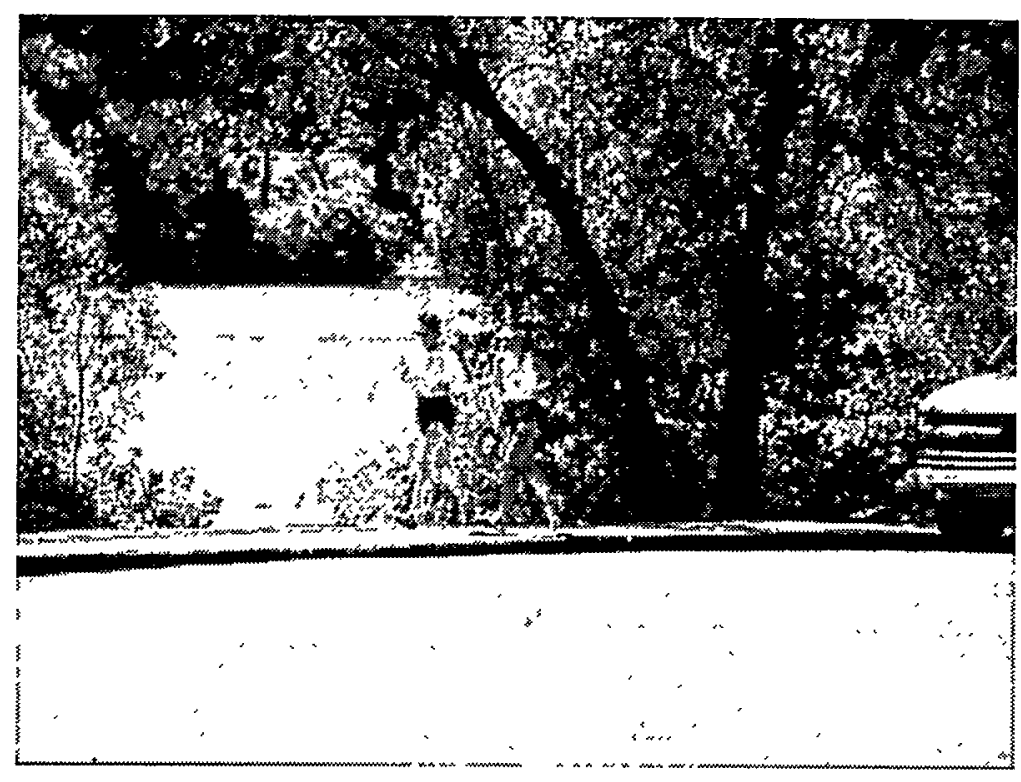





\section{DOSE TO THE PUBLIC}

\subsection{GENERAL INFORMATION}

Typically the radiological impact of INEEL operations on the public surrounding the INEEL has been too small to be measured by routine monitoring programs. Because of this, radiological impacts resulting from INEEL operations have been estimated using the reported amounts of radionuclides released during the year from INEEL facilities and appropriate air dispersion models to estimate the concentrations of radionuclides at selected locations surrounding the INEEL. During 1998, this was accomplished for the radionuclides summarized in Table 7-1.

The following estimates were calculated:

- the effective dose equivalent to the maximally-exposed individual residing offsite using the CAP-88 model;

- the effective dose equivalent to the maximally-exposed individual residing offsite using dispersion calculations from the MDIFF (mesoscale diffusion) model [Reference 8-1]; and

- the collective effective dose equivalent (population dose) within an 80-km (50-mi) radius of the operations center of the Site (the Test Reactor Area [TRA] and the Idaho Nuclear Technology and Engineering Center [INTEC]). The estimated population dose was based on the effective dose equivalent calculated with the MDIFF air dispersion model for the maximally-exposed individual.

In this chapter, the term dose will refer to effective dose equivalent unless another term is specifically stated. Dose was calculated by summing the committed dose equivalents to organs, each multiplied by a weighting factor proportional to each organ's sensitivity to radiation. Effective dose equivalent includes doses received from both external and internal sources and represents the same risk as if an individual's body were uniformly irradiated. U.S.
Department of Energy (DOE) dose conversion factors and a 50-year integration period were used for internally deposited radionuclides [Reference 8-2] and for radionuclides deposited on ground surfaces [Reference 8-3] in calculations with both air dispersion models. Because the hypothetical dose to the maximally-exposed individual residing near the INEEL is so low, no allowance is made in the MDIFF model for shielding by housing materials, which is estimated to reduce the dose by about 30 percent. Neither was less-than-yearround occupancy time in the community. The CAP-88 model, used by all sites regardless of the magnitude of the hypothetical dose, includes a factor to allow for shielding by housing materials and occupancy time.

Of the potential exposure pathways by which radioactive materials from INEEL operations could be transported offsite, atmospheric transport is likely to be the principal potential pathway. This is the likely exposure pathway since radionuclides from the INEEL have not been found in drinking water wells offsite. Because of this, the maximally-exposed individual dose is determined through the use of models using the airborne emissions pathway.

\subsection{MAXIMUM INDIVIDUAL DOSE - AIRBORNE EMISSIONS PATHWAY}

\section{Summary of Models}

During 1998, U.S. Environmental Protection Agency (EPA) regulations limiting quantities of airborne radionuclides released from any nuclear facility were in effect. The standard required the dose received by any member of the public to be less than $10 \mathrm{mrem} / \mathrm{yr}$, as determined using the CAP-88 computer model.

The MDIFF (formerly known as MESODIF) air dispersion model has been in use for over 20 years to calculate doses to members of the public residing near the INEEL. The MDIFF dif- 
fusion curves, developed from tests in desert environments (i.e. INEEL and the Hanford Site in eastern Washington) may be more appropriate for the INEEL than CAP-88. In previous years, doses calculated with the MDIFF air dispersion model have been somewhat higher than doses calculated using CAP-88. Differences between the two models were discussed in detail in the 1986 annual report [Reference 8-4]. The offsite concentrations calculated using both models were compared to actual monitoring results at offsite locations in 1986 , 1987, and 1988. Concentrations calculated for several locations using the MDIFF model showed good agreement with concentrations from actual measurements, with the model generally predicting concentrations higher than those measured [References 8-5, 8-6, and 87].

There are differences in the atmospheric dispersion portions of the MDIFF and CAP-88 air dispersion codes. CAP- 88 makes its calculations based on the joint frequency of wind conditions from a single wind station located near the source. MDIFF calculates the individual trajectories using winds from about 30 towers in the upper Snake River Plain. For this reason the two models may not agree on the location of the maximum dose.

\section{CAP-88 Model Results}

For the 1998 calculations at the INEEL, 63 potential maximum locations were evaluated. The CAP- 88 model predicted the highest dose to be at Frenchman's Cabin, located at the southern boundary of the INEEL. Although this location is only inhabited during portions of the year, it meets the EPA's definition of a residence. At Frenchman's Cabin, a hypothetical dose of $0.007 \mathrm{mrem}$ was calculated. The facilities making the largest contributions to this dose were the Test Reactor Area at 36 percent, diffuse sources of radioactivity at the Radioactive Waste Management Complex with 33 percent, and the Idaho Nuclear Technology and Engineering Center accounting for about 25 percent. The dose of $0.007 \mathrm{mrem}$ is 0.07 percent of the EPA radiation protection standard.

\section{MDIFF Model Results}

Using data gathered continuously at meteorological stations on and around the INEEL and the MDIFF model, the National Oceanic and Atmospheric Administration Air Resources Laboratory (NOAA-ARL) prepares a mesoscale map (Figure 8-1) showing the calculated 1998 concentrations normalized to a unit release rate for TRA and INTEC. To obtain the average air concentration $\left(\mathrm{Ci} / \mathrm{m}^{3}\right)$ for a radionuclide released from TRA and INTEC along any dispersion coefficient isopleth (line of equal air concentration) in Figure 8-1, the value of the dispersion coefficient is multiplied by the number of curies of the radionuclide released during the year and divided by the square of the number of hours in a year $\left(7.67 \times 10^{7}\right)$.

The MDIFF model predicts that the highest concentrations of radionuclides in the air at an inhabited area during 1998 would have occurred south of Mud Lake, Idaho. The maximum hypothetical dose was calculated for an adult resident of that location from inhalation of air, submersion in air, ingestion of radioactivity on leafy vegetables, ingestion of milk, and exposure due to deposition of radioactive particles on ground surfaces. The calculation was based on data presented in Table 7-1 and in Figure 8-1.

Using the calculated dispersion coefficient of $33.8 \times 10^{-9}$, the largest dispersion coefficient value from TRA/INTEC at a location inhabited by a full-time resident, and allowing for radioactive decay during the $53-\mathrm{km}$ (33-mi) transit of the radionuclides from TRA/NTEC to Mud Lake, the potential effective dose equivalent from all radionuclides released was calculated to be $0.008 \mathrm{mrem}\left(8 \times 10^{-5} \mathrm{mSv}\right)$ (Table $8-1$ ). This dose is 0.008 percent of the DOE radiation protection standard for a prolonged period of exposure to a member of the public from all pathways and 0.08 percent of the EPA standard for the airborne pathway only. 


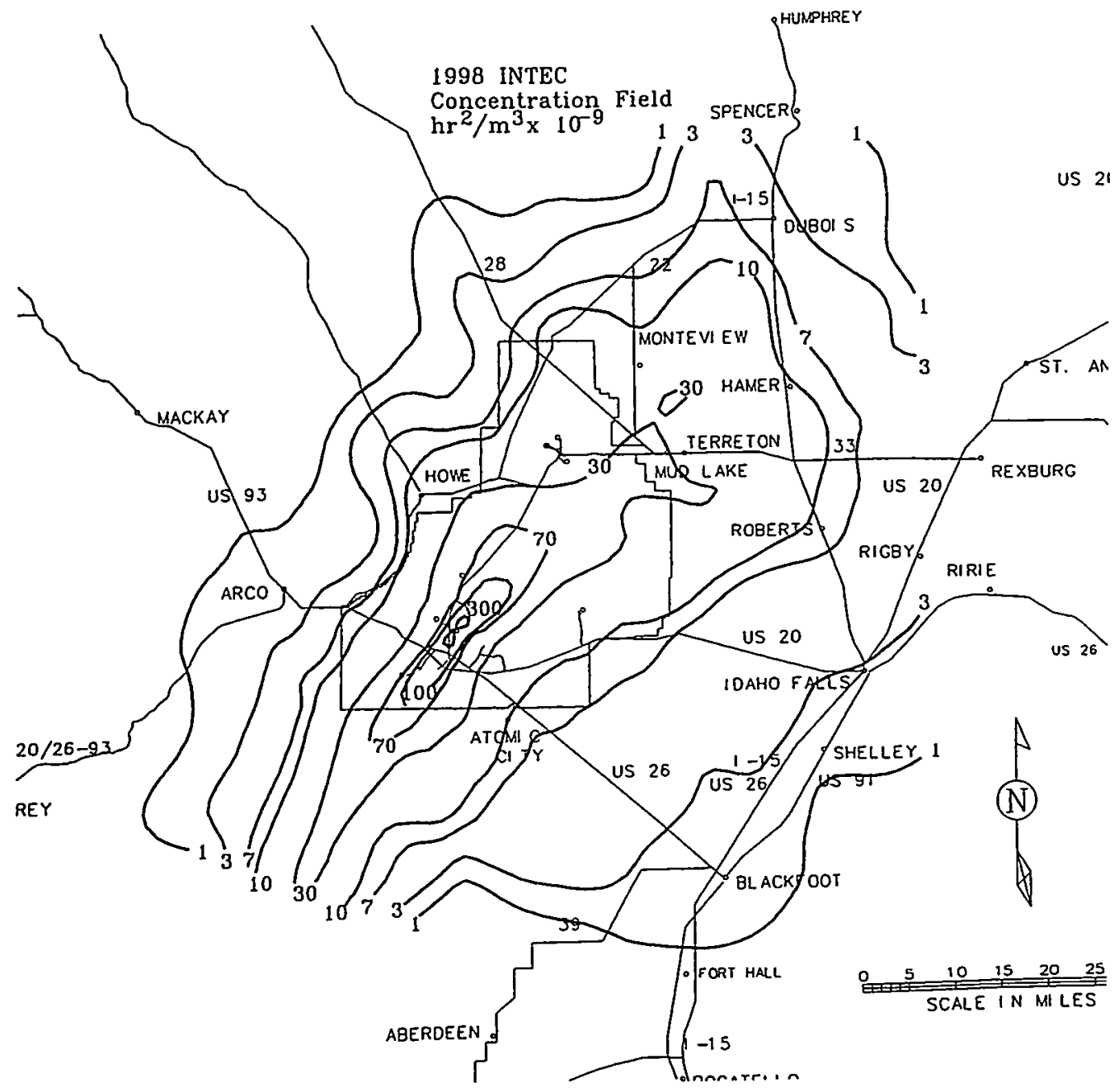

Figure 8-1. Average Mesoscale Dispersion Isopleths of Air Concentrations at Ground Level, Normalized to Unit Release Rate for TRA/INTEC

Of the dose received, the ingestion pathway accounted for 71 percent of the total, with the immersion pathway accounting for 22 percent. For $1998,{ }^{129}$ l contributed approximately 76 percent of the total dose, and ${ }^{41} \mathrm{Ar}$ contributed 22 percent (Figure 8-2).
The calculated maximum dose resulting from INEEL operations is a small fraction of the average dose received by individuals in southeastern Idaho from cosmic and terrestrial sources of naturally-occurring radiation found in the environment. The total annual dose from 
Table 8-1. Maximum Individual Effective Dose Equivalent (1998)

\begin{tabular}{|c|c|c|c|}
\hline \multirow[b]{2}{*}{ Radionuclide $^{\circ}$} & \multirow{2}{*}{$\begin{array}{c}\text { Maximum Offsite }{ }^{c} \\
\text { Concentration ( } \mu \mathrm{Ci} / \mathrm{mL})\end{array}$} & \multicolumn{2}{|c|}{ Maximum Effective Dose Equivalent } \\
\hline & & mrem & $\underline{\mathrm{mSv}}$ \\
\hline$\overline{129 \mid}$ & $7.7 \times 10^{-18}$ & $6.3 \times 10^{-3}$ & $6 . \overline{3 \times 10^{-5}}$ \\
\hline${ }^{41} \mathrm{Ar}$ & $2.7 \times 10^{-13}$ & $1.8 \times 10^{-3}$ & $1.8 \times 10^{-5}$ \\
\hline${ }^{90} S r+D^{b}$ & $1.4 \times 10^{-19}$ & $5.0 \times 10^{-5}$ & $5.0 \times 10^{-7}$ \\
\hline${ }^{137} \mathrm{Cs}+\mathrm{D}$ & $5.7 \times 10^{-19}$ & $2.8 \times 10^{-5}$ & $2.8 \times 10^{-7}$ \\
\hline${ }^{3} \mathrm{H}$ & $4.6 \times 10^{-14}$ & $2.4 \times 10^{-5}$ & $2.4 \times 10^{-7}$ \\
\hline${ }^{8} \mathrm{Kr}$ & $2.1 \times 10^{-12}$ & $2.3 \times 10^{-5}$ & $2.3 \times 10^{-7}$ \\
\hline${ }^{135} \mathrm{Xe}$ & $7.2 \times 10^{-15}$ & $8.9 \times 10^{-6}$ & $8.9 \times 10^{-8}$ \\
\hline${ }^{238} \mathrm{pu}$ & $2.2 \times 10^{-2 i}$ & $8.6 \times 10^{-6}$ & $8.6 \times 10^{-8}$ \\
\hline${ }^{14} \mathrm{C}$ (organic) & $3.5 \times 10^{-16}$ & $6.2 \times 10^{-6}$ & $6.2 \times 10^{-8}$ \\
\hline 131 | & $2.9 \times 10^{-19}$ & $5.5 \times 10^{-6}$ & $5.5 \times 10^{-8}$ \\
\hline${ }^{60} \mathrm{Co}$ & $2.9 \times 10^{-20}$ & $2.9 \times 10^{-6}$ & $2.9 \times 10^{-8}$ \\
\hline${ }^{239} \mathrm{Pu}$ & $2.3 \times 10^{-22}$ & $1.0 \times 10^{-6}$ & $1.0 \times 10^{6}$ \\
\hline $\begin{array}{l}\text { - Table includes only } \\
\text { b When indicated }(+\mathrm{C} \\
{ }^{\circ} \text { Estimate of radioa }\end{array}$ & $\begin{array}{l}\text { uclides which contribute a dose of } \\
\text { contribution of progeny decay pro } \\
\text { lecay uses the distance to the } \mathrm{Mu}\end{array}$ & $\begin{array}{l}O \times 10^{-6} \text { mrem or mo } \\
\text { icts was also include } \\
\text { Lake area and the } 1\end{array}$ & $\begin{array}{l}\text { alculations. } \\
\text { ad speed. }\end{array}$ \\
\hline
\end{tabular}

all natural sources is estimated at approximately 360 mrem (Table 4-11).

\subsection{MAXIMUM INDIVIDUAL DOSE: GAME INGESTION PATHWAY}

Waterfowl. The potential dose an individual may receive from the occasional ingestion of meat from game animals continues to be investigated at the INEEL. Such studies include the potential dose to individuals who may eat waterfowl that reside briefly at waste ponds used for the disposal of low-level radioactive wastes and dose to individuals who may eat game birds and game animals which may migrate across the INEEL.

Following the construction of two hypalon-lined evaporation ponds at TRA and the closure of the percolation ponds formerly used for disposal of wastes at this facility, the Environmental Science and Research Foundation initiated a study in 1994 to obtain current data on potential doses from game animals using the ponds.

During 1998, waterfowl were collected from radioactive waste disposal ponds at TRA and INTEC and a sewage pond at Argonne
National Laboratory-West (ANL-W). Control samples were also collected from Fort Hall. Radionuclide concentrations in the edible portion of the waterfowl reported in Table 4-8 were used to estimate the potential dose to an individual consuming waterfowl from each facility. Estimated doses are based on the assumption that waterfowl are killed and eaten immediately after leaving the ponds. A lower dose would be more realistic due to the biological elimination of the radioactivity. For example, a significant contributor to the dose,

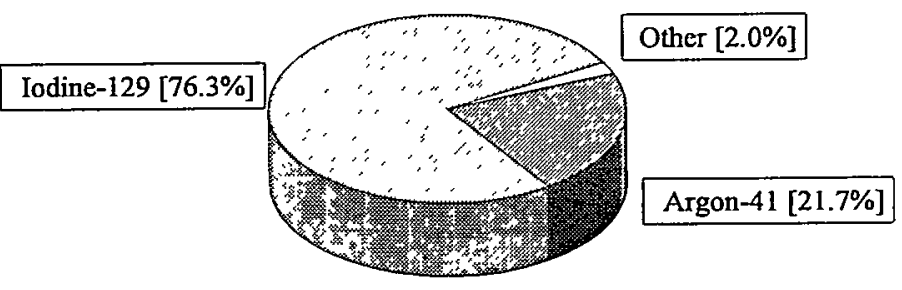

Figure 8-2. Radionuclides Contributing to Maximum Individual Dose (1998) 
Table 8-2. Maximum Potential Committed (50 yr) Effective Dose Equivalents from Ingestion of Muscle Tissue of Waterfowl

Using INEEL Waste Disposal Ponds In 1998 (mrem)

\begin{tabular}{lcccc}
\hline Radionuclide & $\begin{array}{c}\text { TRA } \\
\text { Evaporation } \\
\text { Ponds }\end{array}$ & $\begin{array}{c}\text { INTEC } \\
\text { Percolation } \\
\text { Pond }\end{array}$ & $\begin{array}{c}\text { Argonne National } \\
\text { Laboratory-West } \\
\text { Pond }\end{array}$ & $\begin{array}{c}\text { Control } \\
\text { (Fort Hall) }\end{array}$ \\
${ }^{{ }^{56} \mathrm{Mn}}$ & $2.9 \times 10^{-6}$ & 0 & 0 & 0 \\
${ }^{58} \mathrm{Co}$ & 0 & 0 & $7.9 \times 10^{-5}$ & 0 \\
${ }^{60} \mathrm{Co}$ & $1.1 \times 10^{-3}$ & 0 & 0 & 0 \\
${ }^{65} \mathrm{Zn}$ & $1.9 \times 10^{-3}$ & $4.7 \times 10^{-5}$ & 0 & 0 \\
${ }^{90} \mathrm{Sr}$ & 0 & 0 & $1.6 \times 10^{-3}$ & 0 \\
${ }^{134} \mathrm{Cs}$ & 0 & $5.1 \times 10^{-5}$ & $8.0 \times 10^{-4}$ & $8.1 \times 10^{-5}$ \\
${ }^{137} \mathrm{Cs}$ & $5.3 \times 10^{-3}$ & $1.2 \times 10^{-2}$ & $8.0 \times 10^{-4}$ & $9.5 \times 10^{-5}$ \\
${ }^{141} \mathrm{Ce}$ & 0 & $1.0 \times 10^{-5}$ & 0 & $7.1 \times 10^{-5}$ \\
${ }^{238} \mathrm{Pu}$ & 0 & $2.0 \times 10^{-3}$ & 0 & 0 \\
Total & $8.4 \times 10^{-3}$ & $1.4 \times 10^{-2}$ & $3.3 \times 10^{-3}$ & $2.5 \times 10^{-4}$ \\
\hline
\end{tabular}

Assumes the consumption of $225 \mathrm{~g}(8 \mathrm{oz})$ of muscle containing maximum observed concentrations of each radionuclide.

${ }^{137} \mathrm{Cs}$, has an effective half-life in mallard ducks of 11.2 days [Reference 8-8]. This means that half of the ${ }^{137} \mathrm{Cs}$ present in the muscle tissue of the duck would be eliminated in 11.2 days. At the end of the next 11.2 days, half of the remaining radioactivity (or one-fourth of the original activity) would be remaining.

During 1998, a total of 12 ducks were collected: four from ANL-W, two from TRA, one from INTEC, and five control samples from Ft. Hall. The maximum potential dose from consuming $225 \mathrm{~g}(8 \mathrm{oz})$ of sampled duck meat was 0.014 mrem from the INTEC duck, 0.008 mrem from a duck at TRA, and 0.003 mrem from a duck at ANL-W (Table 8-2). This compares with 0.0002 mrem for consuming $225 \mathrm{~g}$ of meat from a duck taken at the control location. The potential doses from 1998 waterfowl samples are substantially reduced from the $10 \mathrm{mrem}$ average whole-body dose equivalent from gamma-emitting radionuclides estimated during a 1974 to 1978 study at the former TRA percolation pond [Reference 8-9], and from the 4.0 mrem estimated for the most contaminated duck taken from the percolation pond in 1984 to 1986 [Reference 8-10].

Mourning Doves. During 1998, a total of nine mourning doves were collected, five from TRA and four from INTEC. Control doves were also collected locally. Human-made radionuclide concentrations in the edible portion of the doves reported in Table 4-11 were used to estimate the potential dose resulting from the ingestion of $30 \mathrm{~g}(1 \mathrm{oz})$ of the edible portion of the mourning doves (Table 8-3). The potential dose was $4.2 \times 10^{-6}$ mrem for doves collected at TRA and 0.0004 mrem for doves collected at INTEC (Table 8-3). No manmade radionuclides were found in control samples, so there is no estimated dose from non-natural radionuclides in these samples. The highest estimated potential whole-body dose equivalent to a person eating the entire muscle mass of a mourning dove from the former TRA percolation pond was 0.3 mrem in 1974-1977 [Reference 8-11].

Big Game Animals. A conservative estimate of the potential whole-body dose that could be 
Table 8-3. Maximum Potential Committed (50 yr) Effective Dose Equivalents from Ingestion of Muscle Tissue of Mourning Doves Using INEEL Waste Ponds in 1998 (mrem)

\begin{tabular}{lccc}
\hline $\begin{array}{c}\text { Radio- } \\
\text { nuclide }\end{array}$ & $\begin{array}{c}\text { Control } \\
\text { Samples }\end{array}$ & $\begin{array}{c}\text { TRA } \\
\text { Evaporation } \\
\text { Ponds }\end{array}$ & $\begin{array}{c}\text { INTEC } \\
\text { Percolation } \\
\text { Pond }\end{array}$ \\
${ }^{54} \mathrm{Mn}$ & 0 & $4.2 \times 10^{-6}$ & 0 \\
${ }^{60} \mathrm{Co}$ & 0 & 0 & $2.1 \times 10^{-5}$ \\
${ }^{137} \mathrm{Cs}$ & 0 & 0 & $7.9 \times 10^{-5}$ \\
${ }^{141} \mathrm{Ce}$ & 0 & 0 & $3.0 \times 10^{-4}$ \\
Total & 0 & $4.2 \times 10^{-6}$ & $4.0 \times 10^{-4}$ \\
\hline
\end{tabular}

Assumes the consumption of $30 \mathrm{~g}(1 \mathrm{oz})$ of muscle tissue containing maximum observed concentrations of each radionuclide.

received from an individual eating the entire muscle and liver mass of an antelope with the highest levels of radioactivity found in these animals was estimated at 0.2 mrem in 1975 [Reference 8-12]. Game animals collected at the INEEL during the past few years have shown much lower concentrations than in 1975. Based on the highest concentration of radionuclides found in a game animal during the past several years, the potential dose is now approximately 0.03 mrem.

Yellow-bellied Marmots. During 1998 a total of nine yellow-bellied marmots were collected, six from the RWMC and three from a control location 27 miles $(43 \mathrm{~km})$ southeast of the INEEL. The maximum potential dose was calculated from consuming $225 \mathrm{~g}(8 \mathrm{oz})$ of marmot meat. For 1998 , this potential dose was 0.014 mrem from RWMC marmots, with ${ }^{141} \mathrm{Ce}$ being the largest contributor. For control marmots a potential dose of 0.004 mrem was calculated, primarily from ${ }^{90} \mathrm{Sr}$.

\subsection{0-KILOMETER POPULATION DOSE}

An estimate was made of the collective effective dose equivalent, or population dose, from inhalation, submersion, ingestion, and deposition that could have been received by all members of the public within $80 \mathrm{~km}(50 \mathrm{mi})$ of the TRA/INTEC facilities (Table 8-4). This population dose was calculated by a computer program that multiplies the population number in each square mile by the dispersion coefficient at that point $\left(\mathrm{h}^{2} / \mathrm{m}^{3}\right)$ and the normalized dose received at the location of the maximally-exposed individual $\left(\mathrm{rem} / \mathrm{yr} / \mathrm{h}^{2} / \mathrm{m}^{3}\right)$. This gives an approximation of the dose received by the entire population in a given census division.

The average dose received per person is obtained by dividing the collective effective dose equivalent by the population in that particular census division. This calculation overestimates dose because the model conservatively does not account for radioactive decay of the isotopes during transport over distances greater than the 53 $\mathrm{km}$ (33 mi) from the TRA/INTEC facilities to the residence of the maximally-exposed individual located near Mud Lake. Idaho Falls, for example, is about $66 \mathrm{~km} \mathrm{(41} \mathrm{mi)} \mathrm{from}$ TRAIINTEC. Neither residence time nor shielding by housing was considered when calculating the MDIFF dose on which the collective dose equivalent is based. The calculation also tends to overestimate the population doses because they are extrapolated from the dose computed for the location of the potential maximallyexposed individual. This individual is potentially exposed through ingestion of contaminated leafy vegetables from his garden and ingestion of milk from cows grazing solely upon contaminated pasture grass.

The 1998 MDIFF population dose within each census division was obtained by summing the results from appropriate areas contained within those divisions. The total 80-km (50-mi) population dose was the sum of population doses for the various census divisions. The estimated potential population dose was 0.075 person-rem (0.00075 person-Sv) to a population of about 121,500 . When compared with an approximate population dose of 43,700 person-rem ( 437 person-Sv) from natural background radiation, this represents an increase of only about 0.0002 percent. The dose of 0.075 
Table 8-4. Dose to Population within 80

Kilometers (50 miles) of INEEL Center (1998)

\begin{tabular}{|c|c|c|c|}
\hline \multirow[b]{2}{*}{ Census Division } & \multirow[b]{2}{*}{ Population } & \multicolumn{2}{|c|}{ Population Dose } \\
\hline & & Person-rem & Person-Sv \\
\hline$\overline{\text { Aberdeen }}$ & 2,760 & $2.42 \times 10^{-4}$ & $\overline{2.42 \times 10^{-6}}$ \\
\hline Alridge (part) & 160 & $7.49 \times 10^{-b}$ & $7.49 \times 10^{-7}$ \\
\hline American Falls (part) & 200 & $7.56 \times 10^{-7}$ & $7.56 \times 10^{-9}$ \\
\hline Arco & 2,600 & $1.36 \times 10^{-3}$ & $1.36 \times 10^{-b}$ \\
\hline Atomic City (city) & 25 & $6.57 \times 10^{-5}$ & $6.57 \times 10^{-7}$ \\
\hline Atomic City (division) & 2,300 & $1.74 \times 10^{4}$ & $1.74 \times 10^{-6}$ \\
\hline Blackfoot & 12,450 & $3.34 \times 10^{-3}$ & $3.34 \times 10^{-5}$ \\
\hline Carey (part) & 120 & $8.37 \times 10^{-6}$ & $8.37 \times 10^{-8}$ \\
\hline Challis (part) & 10 & $2.39 \times 10^{-7}$ & $2.39 \times 10^{-9}$ \\
\hline Firth & 3,050 & $1.38 \times 10^{-3}$ & $1.38 \times 10^{-5}$ \\
\hline Fort Hall (part) & 3,920 & $3.13 \times 10^{-4}$ & $3.13 \times 10^{-6}$ \\
\hline Hamer & 2,400 & $1.23 \times 10^{-2}$ & $1.23 \times 10^{-4}$ \\
\hline Howe & 325 & $1.16 \times 10^{-3}$ & $1.16 \times 10^{-5}$ \\
\hline Idaho Falls & 63,500 & $3.64 \times 10^{-2}$ & $3.64 \times 10^{-4}$ \\
\hline Idaho Falls, west & 1,750 & $2.97 \times 10^{-4}$ & $2.97 \times 10^{-6}$ \\
\hline Leadore (part) & 15 & $1.96 \times 10^{-5}$ & $1.96 \times 10^{-7}$ \\
\hline Lewisville-Menan (part) & 2,700 & $2.11 \times 10^{-3}$ & $2.11 \times 10^{-5}$ \\
\hline Mackay & 1,200 & $5.79 \times 10^{-6}$ & $5.79 \times 10^{-8}$ \\
\hline Moreland & 8,150 & $3.38 \times 10^{-3}$ & $3.38 \times 10^{-b}$ \\
\hline Rigby & 1,000 & $7.80 \times 10^{-4}$ & $7.80 \times 10^{-6}$ \\
\hline Roberts & 1,430 & $3.20 \times 10^{-3}$ & $3.20 \times 10^{-5}$ \\
\hline Shelley & 6,400 & $2.94 \times 10^{-3}$ & $2.94 \times 10^{-5}$ \\
\hline Ucon & 4,900 & $3.83 \times 10^{-3}$ & $3.83 \times 10^{-5}$ \\
\hline West Clark & 90 & $5.03 \times 10^{-4}$ & $5.03 \times 10^{6}$ \\
\hline Totals & 121,465 & $7.45 \times 10^{-2}$ & $7.45 \times 10^{-4}$ \\
\hline
\end{tabular}

person-rem can also be compared to the following estimated population doses for the same size population: 3,600 person-rem for medical diagnostic procedures, about 480 person-rem from exposure to highway and road construction materials, and six to 12 personrem for television viewing. The largest collective doses are found in the Idaho Falls and Hamer census divisions. Idaho Falls is relatively high because of its greater population; Hamer is relatively high because it includes areas such as Mud Lake which are in the predominant downwind direction from the INEEL.

\subsection{SUMMARY}

Table 8-5 summarizes the calculated annual effective dose equivalents from 1998 INEEL operations using both CAP-88 and MDIFF air dispersion models. A comparison is shown between these doses and the EPA airborne pathway standard, and to the estimated dose from natural background. The contribution of game animal consumption to the population dose has not been calculated because only a percentage of the population huntsgame, few of the animals killed have spent time on the INEEL, and most of the 
TABLE 8-5. Summary of Annual Effective Dose

\section{Equivalents Due To INEEL Operations (1998)}

\begin{tabular}{|c|c|c|c|}
\hline & \multicolumn{2}{|c|}{ Maximum Dose to an Individual } & \multirow{2}{*}{$\begin{array}{c}\text { Population Dose } \\
\text { MDIFF }\end{array}$} \\
\hline & MDIFF & CAP-88 & \\
\hline Dose & $\begin{array}{l}0.008 \mathrm{mrem} \\
\left(8 \times 10^{-5} \mathrm{msv}\right)\end{array}$ & $\begin{array}{c}0.007 \mathrm{mrem} \\
\left(7 \times 10^{-5} \mathrm{mSv}\right)\end{array}$ & $\begin{array}{c}0.08 \text { person-rem } \\
\left(8 \times 10^{-8} \text { person-Sv }\right)\end{array}$ \\
\hline Location & Mud Lake & Frenchman's Cabin & $\begin{array}{c}\text { Area within an } 80-\mathrm{km} \\
\text { circle }\end{array}$ \\
\hline $\begin{array}{l}\text { Applicable Radiation } \\
\text { Protection Standard }\end{array}$ & $\begin{array}{l}10 \text { mrem } \\
(0.1 \mathrm{msv})\end{array}$ & $\begin{array}{l}10 \text { mrem } \\
(0.1 \mathrm{msv})\end{array}$ & $\cdots$ \\
\hline Percentage of Standard & $0.08 \%$ & $0.07 \%$ & …. \\
\hline Natural Background & $\begin{array}{l}360 \mathrm{mrem} \\
(3.6 \mathrm{mSv})\end{array}$ & $\begin{array}{l}360 \mathrm{mrem} \\
(3.6 \mathrm{msv})\end{array}$ & $\begin{array}{l}\text { 43,700 person-rem } \\
\text { (437 person- } 5 v)\end{array}$ \\
\hline $\begin{array}{c}\text { Percentage of } \\
\text { Background }\end{array}$ & $0.002 \%$ & $0.002 \%$ & $0.0002 \%$ \\
\hline
\end{tabular}

animals that do migrate from the INEEL would have reduced concentrations of radionuclides in their tissues by the time they were harvested. The total population dose contribution from these pathways would, realistically, be less than the sum of population doses from inhalation of air, submersion in air, and deposition on soil. 


\section{Chapter 9 \\ Quality Assurance}

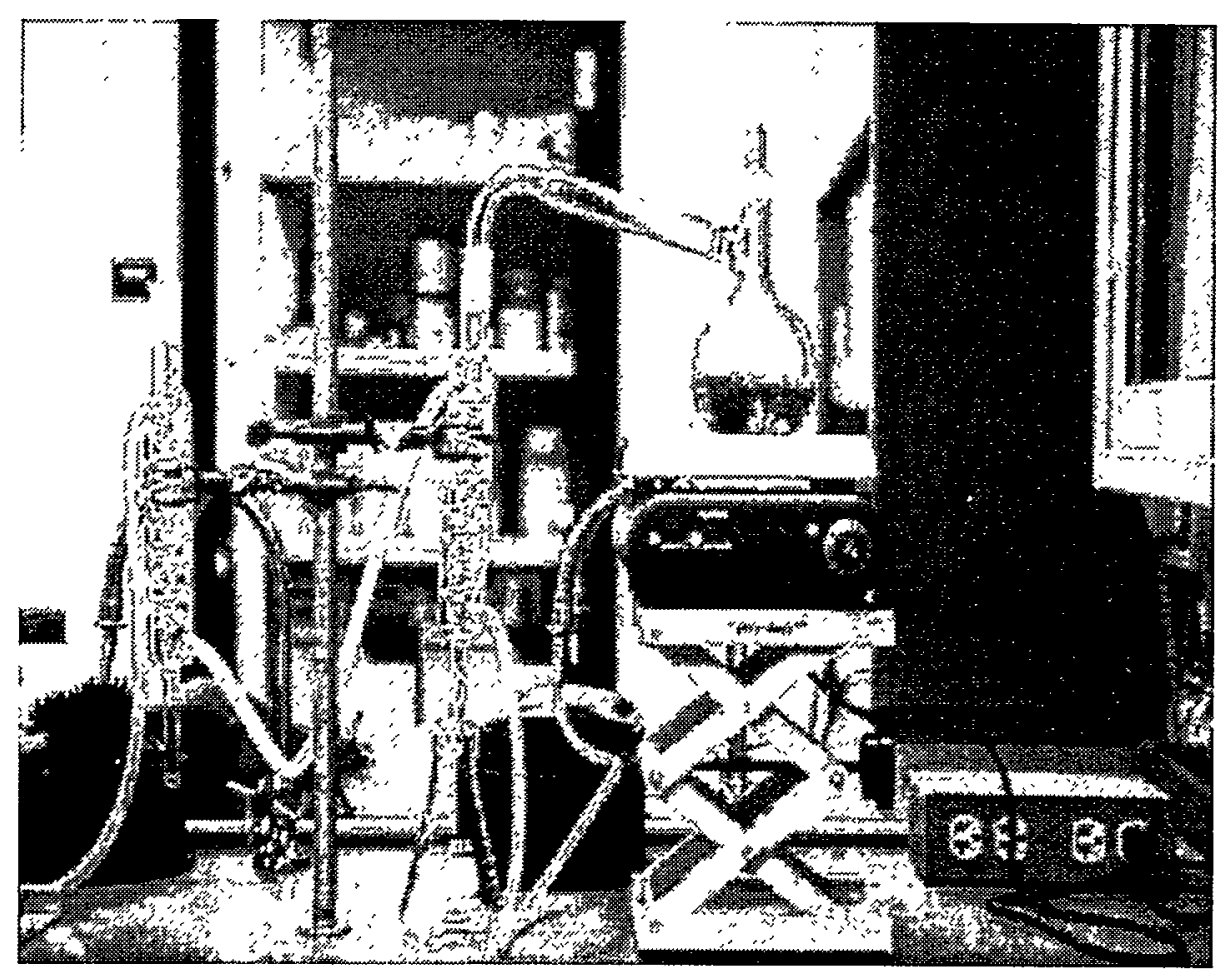


$-\ldots$ 


\section{QUALITY ASSURANCE}

\subsection{QUALITY ASSURANCE PROGRAMS}

Quality control and assurance programs were maintained by contractors conducting environmental monitoring, and by laboratories performing environmental analyses, to ensure accurate and reliable results and to maximize data completeness. Elements of typical quality control programs include the following:

- Adherence to peer-reviewed written procedures for sample collection and analytical methods.

- Documentation of program changes.

- Periodic calibration of instruments with standards traceable to the National Institute of Standards and Technology.

- Chain of custody procedures.

- Equipment performance checks.

- Routine yield determinations of radiochemical procedures.

- Replicate samples to determine precision.

- Analysis of blind duplicate and replicate samples.

- Analysis of quality control standards in appropriate matrices to test accuracy.

- Analysis of reagent blanks to verify that no radiochemical contamination occurs during analysis.

- Analysis of blind spike samples (samples containing a known amount of a contaminant) to verify the accuracy of a measurement.

- Internal and external surveillance to verify quality elements.

- Data verification and validation programs.

\subsection{LABORATORY INTERCOMPARISON PROGRAMS}

\section{General Information}

Radiological data reported in this document were obtained from several commercial, university, government, and government contractor laboratories, including the Idaho State University Environmental Assessment Laboratory (EAL), General Engineering Laboratory, the INEEL M\&O contractor's Radiological Measurements Laboratory, Paragon Analytics, Inc., the DOE Radiological and Environmental Sciences Laboratory (RESL), and Quanterra, Inc. These laboratories participate in a variety of programs to ensure the quality of their analytical data.

\section{Quality Assessment Program (QAP)}

The QAP is administered by DOE's Environmental Measurements Laboratory (EML) in New York. EML prepares quality control samples containing various alpha-, beta-, and gammaemitting nuclides in water, soil, air filter, vegetation, and tissue media and distributes them to numerous DOE contractor laboratories throughout the country. The program is an interlaboratory comparison in that results from the participants are compared with the experimentally determined results of EML. EML issues QAP Reports twice per year in which the identities of participating laboratories, their results, and comparison to EML results are presented. Results from the QAP are presented in Tables 9-1 to 9-5 for laboratories used during 1998.

\section{National Institute of Standards and Tech- nology (NIST)}

RESL participates in a traceability program administered through NIST. NIST prepares several alpha-, beta-, and gamma-emitting standards, generally in liquid media, for analysis by RESL. 


\section{EPA Intercomparison Studies Program}

The EPA's Environmental Monitoring Systems Laboratory in Las Vegas, Nevada coordinates an intercomparison program for radionuclides in water. The laboratories used by contractors performing environmental monitoring at the INEEL participate in this program.

\section{Dosimetry}

To verify the quality of the environmental dosimetry program conducted by LMITCO, the Operational Dosimetry Unit has participated in 11 International Environmental Dosimeter Intercomparison Studies. The Operational Dosimetry Unit's results were within \pm 30 percent of the test exposure values on all intercomparisons. Quality control of the environmental dosimetry program is maintained through internal check measurements every month.

\section{Blind Spikes}

The Foundation purchases samples spiked with various radioactive nuclides from Analytics, Inc. and submits these spikes, disguised as samples, to the laboratories performing the Foundation's environmental analyses. The analytical results are expected to compare to the known value to within \pm 20 percent or three standard deviations.

\section{Other Programs}

INEEL contractors participate in additional performance evaluation programs, including those administered by the International Atomic Energy Agency and the American Society for Testing and Materials. Where possible, contractors use laboratories that are certified by the State of Idaho or certified by another state whose certification is recognized by the State of Idaho.

\subsection{DATA PRECISION AND VERIFICATION}

\section{Duplicate Sampling}

As a measure of the quality of data collected, the Foundation, the INEEL M\&O contractor, the USGS, and other contractors performing monitoring used a variety of quality control samples of different media. Quality control samples include duplicate samples (separate samples taken at the same time), split samples (two portions of a sample that are analyzed separately), and spike samples (samples to which a known amount of a contaminant is added).

Both the Foundation and the INEEL M\&O contractor maintained duplicate air samplers at two locations during 1998 (Table 9-6). The Foundation operated duplicate samplers at Reno Ranch and Arco and the M\&O contractor samplers were at the Central Facilities Area (CFA) and Test Area North (TAN). Filters from these samplers were collected and analyzed in the same manner as filters from regular air samplers. 
Table 9-1. Environmental Measurements Laboratory (EML) Quality Assessment Program Results for Environmental Assessment Laboratory (EAL) (1998)

\begin{tabular}{|c|c|c|c|c|c|c|c|}
\hline \multirow[b]{2}{*}{ Medium } & \multirow[b]{2}{*}{ Units } & \multirow[b]{2}{*}{$\underline{\text { Radionuclide }}$} & \multicolumn{2}{|c|}{ EAL } & \multicolumn{2}{|c|}{ EML } & \multirow{2}{*}{$\begin{array}{c}\text { EAL/EML } \\
\text { Ratio }\end{array}$} \\
\hline & & & $\frac{\text { Value }}{\text { June D }}$ & Error & Value & Error & \\
\hline \multirow[t]{7}{*}{ Air } & Bq/filter & ${ }^{54} \mathrm{Mn}$ & 5.7 & 0.2 & 5.4 & 0.5 & 1.05 \\
\hline & & ${ }^{57} \mathrm{Co}$ & 11.0 & 0.2 & 11.1 & 0.8 & 0.99 \\
\hline & & ${ }^{60} \mathrm{Co}$ & 9.6 & 0.2 & 9.1 & 0.7 & 1.06 \\
\hline & & ${ }^{125} \mathrm{Sb}$ & 11.3 & 0.2 & 12.2 & 1.2 & 0.93 \\
\hline & & ${ }^{134} \mathrm{Cs}_{s}$ & 19.8 & 0.2 & 20 & 1 & 1.00 \\
\hline & & ${ }^{137} \mathrm{Cs}_{5}$ & 12.3 & 0.3 & 11.9 & 1.0 & 1.04 \\
\hline & & ${ }^{144} \mathrm{Ce}$ & 7.9 & 0.6 & 8.2 & 0.8 & 0.96 \\
\hline \multirow[t]{2}{*}{ Soil } & $\mathrm{Bq} / \mathrm{kg}$ & ${ }^{40} K$ & 506 & 31 & 314 & 10 & 1.62 \\
\hline & & ${ }^{137} \mathrm{Cs}_{5}$ & 496 & 10 & 330 & 9 & 1.51 \\
\hline \multirow[t]{3}{*}{ Vegetation } & $\mathrm{Bq} / \mathrm{kg}$ & ${ }^{40} \mathrm{~K}$ & 976 & 49 & 708 & 25 & 1.38 \\
\hline & & ${ }^{60} \mathrm{Co}$ & 14.4 & 0.9 & 10.6 & 0.2 & 1.36 \\
\hline & & ${ }^{137} \mathrm{C}_{5}$ & 247 & 5 & 182 & 7 & 1.36 \\
\hline \multirow[t]{3}{*}{ Water } & $\mathrm{Bq} / \mathrm{L}$ & ${ }^{54} \mathrm{Mn}$ & 63 & 1 & 57 & 2 & 1.10 \\
\hline & & ${ }^{60} \mathrm{Co}$ & 14.7 & 0.3 & 13.6 & 1.2 & 1.08 \\
\hline & & ${ }^{137} \mathrm{Cs}_{5}$ & 52 & 1 & 46 & 2 & 1.13 \\
\hline \multicolumn{8}{|c|}{ December Distribution } \\
\hline \multirow[t]{6}{*}{ Air } & Bq/filter & Gross alpha & 1.99 & 0.03 & 1.65 & 0.16 & 1.21 \\
\hline & & Gross beta & 2.22 & 0.02 & 2.16 & 0.07 & 1.03 \\
\hline & & ${ }^{54} \mathrm{Mn}$ & 4.9 & 0.1 & 4.9 & 0.4 & 1.00 \\
\hline & & ${ }^{60} \mathrm{Co}$ & 8.9 & 0.1 & 9.2 & 0.6 & 0.97 \\
\hline & & ${ }^{125} 5 b$ & 9.2 & 0.1 & 8.9 & 0.6 & 1.04 \\
\hline & & ${ }^{137} \mathrm{Cs}$ & 21.3 & 0.3 & 23 & 1 & 0.95 \\
\hline \multirow[t]{9}{*}{ Soil } & $\mathrm{Bq} / \mathrm{kg}$ & ${ }^{40} \mathrm{~K}$ & 610 & 90 & 314 & 13 & 1.94 \\
\hline & & ${ }^{137} \mathrm{Cs}_{5}$ & 995 & 18 & 954 & 38 & 1.04 \\
\hline & & ${ }^{208} \mathrm{TI}$ & 23 & 1 & 18 & 1 & 1.26 \\
\hline & & ${ }^{212} \mathrm{Bi}$ & 64 & 4 & 58 & 6 & 1.10 \\
\hline & & ${ }^{212} \mathrm{~Pb}$ & 64 & 4 & 53 & 4 & 1.21 \\
\hline & & ${ }^{214} \mathrm{Bi}$ & 49 & 7 & 29 & 0.5 & 1.71 \\
\hline & & ${ }^{214} \mathrm{~Pb}$ & 49 & 7 & 29 & 1 & 1.69 \\
\hline & & ${ }^{226} \mathrm{Ra}$ & 63 & 8 & 29 & 1 & 2.16 \\
\hline & & ${ }^{228} \mathrm{AC}$ & 79 & 7 & 53 & 3 & 1.50 \\
\hline \multirow[t]{3}{*}{ Vegetation } & $\mathrm{Bq} / \mathrm{kg}$ & ${ }^{40} K$ & 580 & 100 & 460 & 20 & 1.26 \\
\hline & & ${ }^{60} \mathrm{Co}$ & 19 & 3 & 20 & 1 & 0.94 \\
\hline & & ${ }^{137} \mathrm{Cs}$ & 438 & 10 & 390 & 20 & 1.12 \\
\hline \multirow[t]{5}{*}{ Water } & $B \cdot q / L$ & Gross alpha & 1035 & 29 & 1080 & 60 & 0.96 \\
\hline & & Gross beta & 1060 & 26 & 1420 & 60 & 1.75 \\
\hline & & ${ }^{54} \mathrm{Mn}$ & 36 & 0.5 & 32 & 1 & 1.11 \\
\hline & & ${ }^{60} \mathrm{Co}$ & 52.2 & 0.6 & 49 & 1 & 1.06 \\
\hline & & ${ }^{137} \mathrm{CS}_{5}$ & 52.3 & 0.8 & 50 & 2 & 1.05 \\
\hline
\end{tabular}

The EML value is the mean of replicate determinations for each radionuclide. The EML error is the standard error of the mean. 
Table 9-2. Environmental Measurements Laboratory (EML) Quality Assessment Program Results for General Engineering Labs (GEL) (1998)

\begin{tabular}{|c|c|c|c|c|c|c|c|}
\hline \multirow[b]{2}{*}{ Medium } & \multirow[b]{2}{*}{ Units } & \multirow[b]{2}{*}{ Radionuclide } & \multicolumn{2}{|c|}{ GEL } & \multicolumn{2}{|c|}{ EML } & \multirow{2}{*}{$\begin{array}{c}\text { GEL/EML } \\
\text { Ratio }\end{array}$} \\
\hline & & & Value & Error & Value & Error & \\
\hline & & & \multicolumn{2}{|c|}{ December Distribution } & & & \\
\hline \multirow[t]{13}{*}{ Air } & Bq/filter & Gross alpha & 1.632 & 0.007 & 1.65 & 0.16 & 0.99 \\
\hline & & Gross beta & 1.780 & 0.004 & 2.14 & 0.07 & 0.82 \\
\hline & & ${ }^{54} \mathrm{Mn}$ & 5.3 & 1.0 & 4.9 & 0.4 & 1.08 \\
\hline & & ${ }^{\infty} \mathrm{Co}$ & 9.2 & 1.6 & 9.2 & 0.6 & 1.00 \\
\hline & & ${ }^{90} \mathrm{Sr}$ & 1.18 & 0.10 & 1.12 & 0.05 & 1.06 \\
\hline & & ${ }^{137} \mathrm{Cs}$ & 23 & 3 & 23 & 1 & 1.00 \\
\hline & & $125 \mathrm{Sb}$ & 2.7 & 1.1 & 8.9 & 0.6 & 0.31 \\
\hline & & ${ }^{238} \mathrm{Pu}$ & 0.51 & 0.12 & 0.46 & 0.01 & 1.11 \\
\hline & & ${ }^{239} \mathrm{Pu}$ & 0.46 & 0.11 & 0.42 & 0,01 & 1.10 \\
\hline & & ${ }^{241} \mathrm{Am}$ & 0.55 & 0.14 & 0.51 & 0.01 & 1.08 \\
\hline & & ${ }^{234} \mathrm{U}$ & 0.24 & 0.07 & 0.26 & 0.01 & 0.93 \\
\hline & & ${ }^{238} \mathrm{U}$ & 0.25 & 0.07 & 0.26 & 0.01 & 0.95 \\
\hline & $\mu g / f i l t e r$ & UUG & 16.9 & 0.7 & 21.0 & 0.1 & 0.81 \\
\hline \multirow[t]{14}{*}{ Soil } & $\mathrm{Bq} / \mathrm{kg}$ & ${ }^{40} K$ & 350 & 64 & 314 & 13 & 1.12 \\
\hline & & ${ }^{90} \mathrm{Sr}$ & 33 & 4 & 39.63 & 0.003 & 0.83 \\
\hline & & ${ }^{137} \mathrm{Cs}_{5}$ & 981 & 140 & 954 & 38 & 1.03 \\
\hline & & ${ }^{212} \mathrm{Bi}$ & 32 & 15 & 58 & 6 & 0.55 \\
\hline & & $212 \mathrm{pb}$ & 56 & 9 & 53 & 4 & 1.07 \\
\hline & & ${ }^{214} \mathrm{~Pb}$ & 33 & 9 & 29 & 1 & 1.12 \\
\hline & & ${ }^{226} \mathrm{Ra}$ & 30 & 11 & 29 & 1 & 1.03 \\
\hline & & ${ }^{228} \mathrm{AC}$ & 54 & 15 & 53 & 3 & 1.02 \\
\hline & & ${ }^{228} \mathrm{Th}$ & 54 & 15 & 53 & 4 & 1.02 \\
\hline & & ${ }^{234} \mathrm{Th}$ & 109 & 84 & 114 & 6 & 0.96 \\
\hline & & ${ }^{239} \mathrm{Pu}$ & 12.2 & 2.6 & 13.1 & 0.6 & 0.93 \\
\hline & & ${ }^{241} \mathrm{Am}$ & 7.0 & 1.5 & 7.5 & 0.4 & 0.93 \\
\hline & & ${ }^{234} \mathrm{U}$ & 103 & 21 & 113 & 6 & 0.91 \\
\hline & & ${ }^{238} \mathrm{U}$ & 117 & 24 & 120 & 9 & 0.98 \\
\hline \multirow[t]{7}{*}{ Vegetation } & $\mathrm{Bq} / \mathrm{kg}$ & ${ }^{40} \mathrm{~K}$ & 468 & 81 & 460 & 20 & 1.02 \\
\hline & & ${ }^{90} \mathrm{Sr}$ & 588 & 8 & 606 & 40 & 0.97 \\
\hline & & ${ }^{60} \mathrm{Co}$ & 19 & 4 & 20 & 1 & 0.97 \\
\hline & & ${ }^{137} \mathrm{Cs}$ & 377 & 55 & 390 & 20 & 0.97 \\
\hline & & ${ }^{239} \mathrm{Pu}$ & 5.0 & 1.1 & 3.7 & 0.3 & 1.35 \\
\hline & & ${ }^{241} \mathrm{Am}$ & 2.69 & 0.83 & 2.33 & 0.06 & 1.15 \\
\hline & & ${ }^{244} \mathrm{Cm}$ & 2.04 & 0.67 & 1.76 & 0.07 & 1.16 \\
\hline \multirow[t]{15}{*}{ Water } & $\mathrm{Bq} / \mathrm{L}$ & Gross alpha & 1125 & 47 & 1080 & 60 & 1.04 \\
\hline & & Gross beta & 1228 & 39 & 1420 & 60 & 0.87 \\
\hline & & ${ }^{3} \mathrm{H}$ & 92 & 47 & 76 & 3 & 1.21 \\
\hline & & ${ }^{54} \mathrm{Mn}$ & 36 & 6 & 32 & 1 & 1.12 \\
\hline & & ${ }^{55} \mathrm{Fe}$ & 117 & 21 & 139 & 2 & 0.84 \\
\hline & & ${ }^{60} \mathrm{Co}$ & 54 & 8 & 49 & 1 & 1.08 \\
\hline & & ${ }^{63} \mathrm{Ni}$ & 56 & 7 & 96 & 1 & 0.58 \\
\hline & & ${ }^{90} \mathrm{Sr}$ & 0.20 & 0.04 & 2.1 & 0.2 & 0.10 \\
\hline & & ${ }^{137} \mathrm{CS}_{5}$ & 53 & 7 & 20 & 2 & 1.05 \\
\hline & & ${ }^{238} \mathrm{Pu}$ & 1.14 & 0.25 & 1.1 & 0.01 & 1.03 \\
\hline & & ${ }^{239} \mathrm{Pu}$ & 1.46 & 0.31 & 1.41 & 0.04 & 1.04 \\
\hline & & ${ }^{241} \mathrm{Am}$ & 1.23 & 0.24 & 1.25 & 0.08 & 0.98 \\
\hline & & ${ }^{234} U$ & 0.54 & 0.17 & 0.51 & 0.03 & 1.06 \\
\hline & & ${ }^{238} \mathrm{U}$ & 0.52 & 0.17 & 0.52 & 0.05 & 1.00 \\
\hline & $\mu \mathrm{g} / \mathrm{mL}$ & UUG & 0.0405 & 0.0007 & 0.040 & 0.003 & 1.01 \\
\hline
\end{tabular}


Table 9-3. Environmental Measurements Laboratory (EML) Quality Assessment Program Results for LMITCO (1998)

\begin{tabular}{|c|c|c|c|c|c|c|c|}
\hline \multirow{3}{*}{ Medium } & \multirow{3}{*}{$\underline{\text { Units }}$} & \multirow{3}{*}{ Radionuclide } & \multicolumn{2}{|c|}{ LMITCO } & \multicolumn{2}{|c|}{ EML } & \multirow{3}{*}{$\begin{array}{c}\text { LMITCO/ } \\
\text { EML } \\
\text { Ratio }\end{array}$} \\
\hline & & & Value & Error & Value & Error & \\
\hline & & & \multicolumn{2}{|c|}{ June Distribution } & & & \\
\hline \multirow[t]{13}{*}{ Air } & \multirow[t]{13}{*}{$\mathrm{Bq} /$ filter } & ${ }^{54} \mathrm{Mn}$ & 5.6 & 0.3 & 5.4 & 0.5 & 1.02 \\
\hline & & ${ }^{57} \mathrm{Co}$ & 11.3 & 0.6 & 11.1 & 0.8 & 1.02 \\
\hline & & ${ }^{60} \mathrm{Co}$ & 9.0 & 0.5 & 9.1 & 0.7 & 0.99 \\
\hline & & $90 \mathrm{Sr}$ & 1.66 & 0.05 & 1.76 & 0.04 & 0.94 \\
\hline & & ${ }^{125} \mathrm{Sb}$ & 13.8 & 0.7 & 12.2 & 1.2 & 1.14 \\
\hline & & ${ }^{134} \mathrm{Cs}_{5}$ & 20.1 & 1.0 & 20 & 1 & 1.02 \\
\hline & & ${ }^{137} \mathrm{Cs}$ & 11.8 & 0.6 & 11.9 & 1.0 & 1.00 \\
\hline & & ${ }^{144} \mathrm{Ce}$ & 7.7 & 0.5 & 8.2 & 0.8 & 0.93 \\
\hline & & ${ }^{238} \mathrm{Pu}$ & 0.068 & 0.006 & 0.07 & 0.003 & 0.98 \\
\hline & & ${ }^{239} \mathrm{Pu}$ & 0.062 & 0.006 & 0.062 & 0.002 & 0.99 \\
\hline & & ${ }^{241} \mathrm{Am}$ & 0.071 & 0.006 & 0.069 & 0.003 & 1.03 \\
\hline & & ${ }^{234} \mathrm{U}$ & 0.033 & 0.005 & 0.31 & 0.003 & 1.07 \\
\hline & & ${ }^{238} \mathrm{U}$ & 0.033 & 0.005 & 0.031 & 0.001 & 1.08 \\
\hline \multirow[t]{7}{*}{ Soil } & \multirow[t]{7}{*}{$\mathrm{Bq} / \mathrm{kg}$} & ${ }^{40} \mathrm{~K}$ & 339 & 51 & 314 & 10 & 1.08 \\
\hline & & ${ }^{90} \mathrm{Sr}$ & 14.4 & 1.4 & 13.1 & 0.3 & 1.10 \\
\hline & & ${ }^{137} \mathrm{Cs}$ & 391 & 21 & 330 & 9 & 1.19 \\
\hline & & ${ }^{239} \mathrm{Pu}$ & 5.2 & 0.5 & 5.3 & 0.3 & 0.98 \\
\hline & & ${ }^{241} \mathrm{Am}$ & 2.7 & 0.4 & 2.7 & 0.2 & 0.99 \\
\hline & & ${ }^{234} \mathrm{U}$ & 33 & 4 & 31.1 & 0.8 & 1.06 \\
\hline & & ${ }^{238} \mathrm{U}$ & 33 & 4 & 32 & 3 & 1.02 \\
\hline \multirow[t]{8}{*}{ Vegetation } & \multirow[t]{8}{*}{$\mathrm{Bq} / \mathrm{kg}$} & ${ }^{40} \mathrm{~K}$ & 723 & 46 & 708 & 25 & 1.02 \\
\hline & & ${ }^{60} \mathrm{Co}$ & 11.1 & 2.3 & 10.6 & 0.2 & 1.05 \\
\hline & & ${ }^{90} \mathrm{Sr}$ & 362 & 11 & 359 & 6 & 1.01 \\
\hline & & ${ }^{137} \mathrm{Cs}$ & 174 & 14 & 182 & 7 & 0.96 \\
\hline & & ${ }^{238} \mathrm{Pu}$ & 0.13 & 0.03 & 0.12 & 0.04 & 1.12 \\
\hline & & ${ }^{239} \mathrm{Pu}$ & 1.9 & 0.2 & 1.8 & 0.2 & 1.07 \\
\hline & & ${ }^{241} \mathrm{Am}$ & 1.32 & 0.15 & 1.11 & 0.05 & 1.19 \\
\hline & & ${ }^{244} \mathrm{Cm}$ & 2.21 & 0.21 & 2.17 & 0.07 & 1.02 \\
\hline \multirow[t]{12}{*}{ Water } & \multirow[t]{11}{*}{$\mathrm{Bq} / \mathrm{L}$} & Gross alpha & 1723 & 93 & 1421 & 100 & 1.21 \\
\hline & & ${ }^{54} \mathrm{Mn}$ & 60 & 4 & 57 & 2 & 1.06 \\
\hline & & ${ }^{55} \mathrm{Fe}$ & 225 & 100 & 203 & 3 & 1.11 \\
\hline & & ${ }^{60} \mathrm{Co}$ & 15 & 1 & 13.6 & 1.2 & 1.08 \\
\hline & & ${ }^{90} \mathrm{Sr}$ & 4.7 & 0.2 & 4.4 & 0.2 & 1.09 \\
\hline & & ${ }^{137} \mathrm{Cs}_{5}$ & 48 & 3 & 46 & 2 & 1.05 \\
\hline & & ${ }^{238} \mathrm{Pu}$ & 2.38 & 0.19 & 2.53 & 0.06 & 0.94 \\
\hline & & ${ }^{239} \mathrm{Pu}$ & 1.58 & 0.13 & 1.65 & 0.06 & 0.96 \\
\hline & & ${ }^{241} \mathrm{Am}$ & 1.26 & 0.09 & 1.23 & 0.05 & 1.03 \\
\hline & & ${ }^{234} \mathrm{U}$ & 0.41 & 0.06 & 0.40 & 0.03 & 1.03 \\
\hline & & ${ }^{238} \mathrm{U}$ & 0.42 & 0.06 & 0.40 & 0.04 & 1.05 \\
\hline & & & \multicolumn{2}{|c|}{ December Distribution } & & & \\
\hline \multirow[t]{10}{*}{ Air } & \multirow[t]{10}{*}{$\mathrm{Bq} /$ filter } & ${ }^{54} \mathrm{Mn}$ & 5.0 & 0.1 & 4.9 & 0.4 & 1.02 \\
\hline & & ${ }^{50} \mathrm{Co}$ & 8.8 & 0.1 & 9.2 & 0.6 & 0.96 \\
\hline & & ${ }^{90} \mathrm{Sr}$ & 1.23 & 0.05 & 1.1 & 0.05 & 1.10 \\
\hline & & ${ }^{125} \mathrm{Sb}$ & 8.8 & 0.1 & 8.9 & 0.6 & 0.99 \\
\hline & & ${ }^{137} \mathrm{Cs}$ & 21.8 & 0.2 & 23 & 1 & 0.97 \\
\hline & & ${ }^{238} \mathrm{Pu}$ & 0.50 & 0.04 & 0.46 & 0.01 & 1.09 \\
\hline & & ${ }^{239} \mathrm{Pu}$ & 0.46 & 0.03 & 0.42 & 0.01 & 1.10 \\
\hline & & ${ }^{241} \mathrm{Am}$ & 0.57 & 0.04 & 0.51 & 0.01 & 1.11 \\
\hline & & ${ }^{23 A} \mathrm{U}$ & 0.27 & 0.03 & 0.26 & 0.01 & 1.04 \\
\hline & & ${ }^{238} \mathrm{U}$ & 0.28 & 0.04 & 0.26 & 0.01 & 1.09 \\
\hline
\end{tabular}


Table 9-3 (Continued). Environmental Measurements Laboratory (EML) Quality Assessment Program Results for LMITCO (1998)

\begin{tabular}{|c|c|c|c|c|c|c|c|}
\hline \multirow[b]{2}{*}{ Medium } & \multirow[b]{2}{*}{ Units } & \multirow[b]{2}{*}{ Radionuclide } & \multicolumn{2}{|c|}{ LMITCO } & \multicolumn{2}{|c|}{ EML } & \multirow{2}{*}{$\begin{array}{c}\text { LMITCO/ } \\
\text { EML } \\
\text { Ratio }\end{array}$} \\
\hline & & & Value & Error & Value & Error & \\
\hline \multirow[t]{8}{*}{ Soil } & $\overline{B q} / \mathrm{kg}$ & ${ }^{40} K$ & $\overline{350}$ & $\overline{60}$ & $\overline{314}$ & $\overline{13}$ & 1.12 \\
\hline & & $90 \mathrm{Sr}$ & 49 & 2 & 39.6 & 0.01 & 1.23 \\
\hline & & ${ }^{137} \mathrm{Cs}$ & 1110 & 20 & 954 & 38 & 1.16 \\
\hline & & ${ }^{238} \mathrm{pu}$ & 0.45 & 0.08 & 0.53 & 0.27 & 0.85 \\
\hline & & ${ }^{239} \mathrm{Pu}$ & 13.7 & 1.1 & 13.1 & 0.6 & 1.05 \\
\hline & & ${ }^{241} \mathrm{Am}$ & 7.4 & 0.8 & 7.5 & 0.4 & 0.99 \\
\hline & & ${ }^{234} U$ & 106 & 11 & 113 & 6 & 0.94 \\
\hline & & $238 \mathrm{U}$ & 111 & 13 & 120 & 9 & 0.93 \\
\hline \multirow{8}{*}{ Vegetation } & $\mathrm{Bg} / \mathrm{kg}$ & ${ }^{40} \mathrm{~K}$ & 483 & 68 & 460 & 20 & 1.05 \\
\hline & & ${ }^{6} \mathrm{Co}$ & 19 & 2 & 20 & 1 & 0.95 \\
\hline & & ${ }^{90} \mathrm{Sr}$ & 718 & 21 & 606 & 40 & 1.19 \\
\hline & & ${ }^{137} \mathrm{Cs}$ & 397 & 9 & 390 & 20 & 1.02 \\
\hline & & ${ }^{238} \mathrm{Pu}$ & 0.30 & 0.04 & 0.31 & 0.07 & 0.97 \\
\hline & & ${ }^{239} \mathrm{Pu}$ & 4.3 & 0.4 & 3.7 & 0.3 & 1.17 \\
\hline & & ${ }^{241} \mathrm{Am}$ & 2.51 & 0.23 & 2.33 & 0.06 & 1.08 \\
\hline & & ${ }^{244} \mathrm{Cm}$ & 1.89 & 0.18 & 1.76 & 0.07 & 1.07 \\
\hline \multirow[t]{14}{*}{ Water } & $B q / L$ & Gross alpha & 1160 & 70 & 1080 & 60 & 1.07 \\
\hline & & Gross beta & 1630 & 50 & 1420 & 60 & 1.15 \\
\hline & & ${ }^{3} \mathrm{H}$ & 75 & 6 & 76 & 3 & 098 \\
\hline & & ${ }^{54} \mathrm{Mn}$ & 35 & 1 & 32 & 1 & 1.07 \\
\hline & & ${ }^{55} \mathrm{Fe}$ & 114 & 48 & 139 & 2 & 0.82 \\
\hline & & ${ }^{60} \mathrm{Co}$ & 51 & 1 & 49 & 1 & 1.02 \\
\hline & & ${ }^{63} \mathrm{Ni}$ & 78 & 7 & 95.7 & 0.9 & 0.82 \\
\hline & & ${ }^{90} \mathrm{Sr}$ & 2.2 & 0.2 & 2.1 & 0.2 & 1.04 \\
\hline & & ${ }^{137} \mathrm{CS}_{5}$ & 51 & 1 & 50 & 2 & 1.03 \\
\hline & & ${ }^{238} \mathrm{Pu}$ & 1.18 & 0.10 & 1.10 & 0.01 & 1.07 \\
\hline & & ${ }^{239} \mathrm{Pu}$ & 1.54 & 0.13 & 1.41 & 0.04 & 1.09 \\
\hline & & ${ }^{241} \mathrm{Am}$ & 1.24 & 0.10 & 1.25 & 0.08 & 0.99 \\
\hline & & ${ }^{234} U$ & 0.51 & 0.07 & 0.51 & 0.03 & 1.00 \\
\hline & & $238 \mathrm{U}$ & 0.49 & 0.08 & 0.52 & 0.05 & 0.94 \\
\hline
\end{tabular}

The EML value is the mean of replicate determinations for each radionuclide. The EML error is the standard error of the mean. 
Table 9-4. Environmental Measurements Laboratory (EML) Quality Assessment Program Results for Paragon Analytics, Inc. (1998)

\begin{tabular}{|c|c|c|c|c|c|c|c|}
\hline \multirow{3}{*}{ Medium } & \multirow[b]{2}{*}{$\underline{\text { Units }}$} & \multirow[b]{2}{*}{ Radionuclide } & \multicolumn{2}{|c|}{ Paragon } & \multicolumn{2}{|c|}{ EML } & \multirow{2}{*}{$\begin{array}{c}\text { Paragon/ } \\
\text { EML } \\
\text { Ratio }\end{array}$} \\
\hline & & & Value & Error & Value & Error & \\
\hline & & & \multicolumn{2}{|c|}{ June Distribution } & & & \\
\hline \multirow[t]{15}{*}{ Air } & \multirow[t]{14}{*}{$\mathrm{Bq} /$ filter } & ${ }^{54} \mathrm{Mn}$ & 5.6 & 0.4 & 5.4 & 0.5 & 1.04 \\
\hline & & ${ }^{57} \mathrm{Co}$ & 10.4 & 0.7 & 11.1 & 0.8 & 0.94 \\
\hline & & ${ }^{60} \mathrm{Co}$ & 9.0 & 0.6 & 9.1 & 0.7 & 0.99 \\
\hline & & ${ }^{90} \mathrm{Sr}$ & 1.5 & 0.3 & 1.76 & 0.04 & 0.85 \\
\hline & & ${ }^{125} \mathrm{Sb}$ & 13.3 & 0.9 & 12.2 & 1.2 & 1.09 \\
\hline & & ${ }^{134} \mathrm{C}_{5}$ & 19 & 1 & 20 & 1 & 0.96 \\
\hline & & ${ }^{137} \mathrm{Cs}$ & 12.0 & 0.8 & 11.9 & 1.0 & 1.01 \\
\hline & & ${ }^{144} \mathrm{Ce}$ & 7.6 & 0.7 & 8.2 & 0.8 & 0.92 \\
\hline & & ${ }^{238} \mathrm{Pu}$ & 0.06 & 0.01 & 0.07 & 0.003 & 0.86 \\
\hline & & ${ }^{239} \mathrm{Pu}$ & 0.063 & 0.011 & 0.062 & 0.002 & 1.01 \\
\hline & & ${ }^{241} \mathrm{Am}$ & 0.056 & 0.010 & 0.069 & 0.003 & 0.81 \\
\hline & & ${ }^{234} \mathrm{U}$ & 0.045 & 0.008 & 0.31 & 0.003 & 1.45 \\
\hline & & ${ }^{238} \mathrm{U}$ & 0.035 & 0.007 & 0.031 & 0.001 & 1.16 \\
\hline & & $U B Q$ & 0.08 & 0.01 & 0.063 & 0.004 & 1.31 \\
\hline & $\mu g / f i l t e r$ & $U \cup G$ & 3.0 & 0.4 & 2.5 & 0.1 & 1.21 \\
\hline \multirow[t]{9}{*}{ Soil } & \multirow[t]{8}{*}{$\mathrm{Bq} / \mathrm{kg}$} & ${ }^{40} \mathrm{~K}$ & 352 & 36 & 314 & 10 & 1.12 \\
\hline & & ${ }^{90} \mathrm{Sr}$ & 11.1 & 2.4 & 13.1 & 0.3 & 0.85 \\
\hline & & ${ }^{137} \mathrm{Cs}_{5}$ & 385 & 25 & 330 & 9 & 1.17 \\
\hline & & ${ }^{239} \mathrm{Pu}$ & 5.4 & 0.9 & 5.3 & 0.3 & 1.02 \\
\hline & & ${ }^{241} \mathrm{Am}$ & 2.6 & 0.4 & 2.7 & 0.2 & 0.98 \\
\hline & & ${ }^{234} U$ & 28.4 & 3.6 & 31.1 & 0.8 & 0.91 \\
\hline & & $238 \mathrm{U}$ & 28 & 4 & 32 & 3 & 0.88 \\
\hline & & $U B Q$ & 59 & 5 & 65 & 3 & 0.92 \\
\hline & $\mu g / g$ & UUG & 1.8 & 0.3 & 2.6 & 0.2 & 0.68 \\
\hline \multirow[t]{7}{*}{ Vegetation } & \multirow[t]{7}{*}{$\mathrm{Bq} / \mathrm{kg}$} & ${ }^{40} \mathrm{~K}$ & 814 & 64 & 708 & 25 & 1.15 \\
\hline & & ${ }^{60} \mathrm{Co}$ & 10.8 & 1.3 & 10.6 & 0.2 & 1.02 \\
\hline & & ${ }^{90} \mathrm{Sr}$ & 306 & 58 & 359 & 6 & 0.85 \\
\hline & & ${ }^{137} \mathrm{C}_{5}$ & 211 & 14 & 182 & 7 & 1.16 \\
\hline & & ${ }^{239} \mathrm{Pu}$ & 1.5 & 0.3 & 1.8 & 0.2 & 0.87 \\
\hline & & ${ }^{241} \mathrm{Am}$ & 1.15 & 0.16 & 1.11 & 0.05 & 1.04 \\
\hline & & ${ }^{244} \mathrm{~cm}$ & 1.99 & 0.3 & 2.17 & 0.07 & 0.92 \\
\hline \multirow[t]{13}{*}{ Water } & \multirow[t]{11}{*}{$\mathrm{Bq} / \mathrm{L}$} & ${ }^{3} \mathrm{H}$ & 209 & 35 & 218 & 7 & 0.96 \\
\hline & & ${ }^{54} \mathrm{Mn}$ & 62 & 4 & 57 & 2 & 1.09 \\
\hline & & ${ }^{60} \mathrm{Co}$ & 14.8 & 1.1 & 13.6 & 1.2 & 1.03 \\
\hline & & ${ }^{90} \mathrm{Sr}$ & 3.9 & 0.7 & 4.4 & 0.2 & 0.89 \\
\hline & & ${ }^{137} \mathrm{Cs}$ & 51 & 3 & 46 & 2 & 1.11 \\
\hline & & ${ }^{238} \mathrm{Pu}$ & 2.19 & 0.26 & 2.53 & 0.06 & 0.86 \\
\hline & & ${ }^{239} \mathrm{Pu}$ & 1.53 & 0.19 & 1.65 & 0.06 & 0.93 \\
\hline & & ${ }^{241} \mathrm{Am}$ & 1.15 & 0.15 & 1.23 & 0.05 & 0.94 \\
\hline & & ${ }^{234} \mathrm{U}$ & 0.43 & 0.06 & 0.40 & 0.03 & 1.08 \\
\hline & & ${ }^{238} \mathrm{U}$ & 0.43 & 0.06 & 0.40 & 0.04 & 1.08 \\
\hline & & $U B Q$ & 0.88 & 0.08 & 0.80 & 0.07 & 1.10 \\
\hline & \multirow[t]{2}{*}{$\mu g / m L$} & UUG & 0.037 & 0.005 & 0.032 & 0.003 & 1.16 \\
\hline & & & \multicolumn{2}{|c|}{ December Distribution } & & & \\
\hline \multirow[t]{7}{*}{ Air } & $\mathrm{Bq} /$ filter & ${ }^{54} \mathrm{Mn}$ & 5.0 & 1.3 & 4.9 & 0.4 & 1.02 \\
\hline & & ${ }^{60} \mathrm{Co}$ & 8.5 & 1.7 & 9.2 & 0.6 & 0.93 \\
\hline & & ${ }^{90} \mathrm{Sr}$ & 1.0 & 0.2 & 1.1 & 0.05 & 0.89 \\
\hline & & ${ }^{125} \mathrm{Sb}$ & 9.6 & 2.2 & 8.9 & 0.6 & 1.08 \\
\hline & & ${ }^{137} \mathrm{Cs}_{5}$ & 22 & 4 & 23 & 1 & 0.99 \\
\hline & & ${ }^{238} \mathrm{Pu}$ & 0.31 & 0.04 & 0.46 & 0.01 & 0.67 \\
\hline & & ${ }^{239} \mathrm{Pu}$ & 0.30 & 0.04 & 0.42 & 0.01 & 0.72 \\
\hline
\end{tabular}


Table 9-4 (Confinued). Environmental Measurements Laboratory (EML) Quality Assessment Program Results for Paragon Analytics, Inc. (1998)

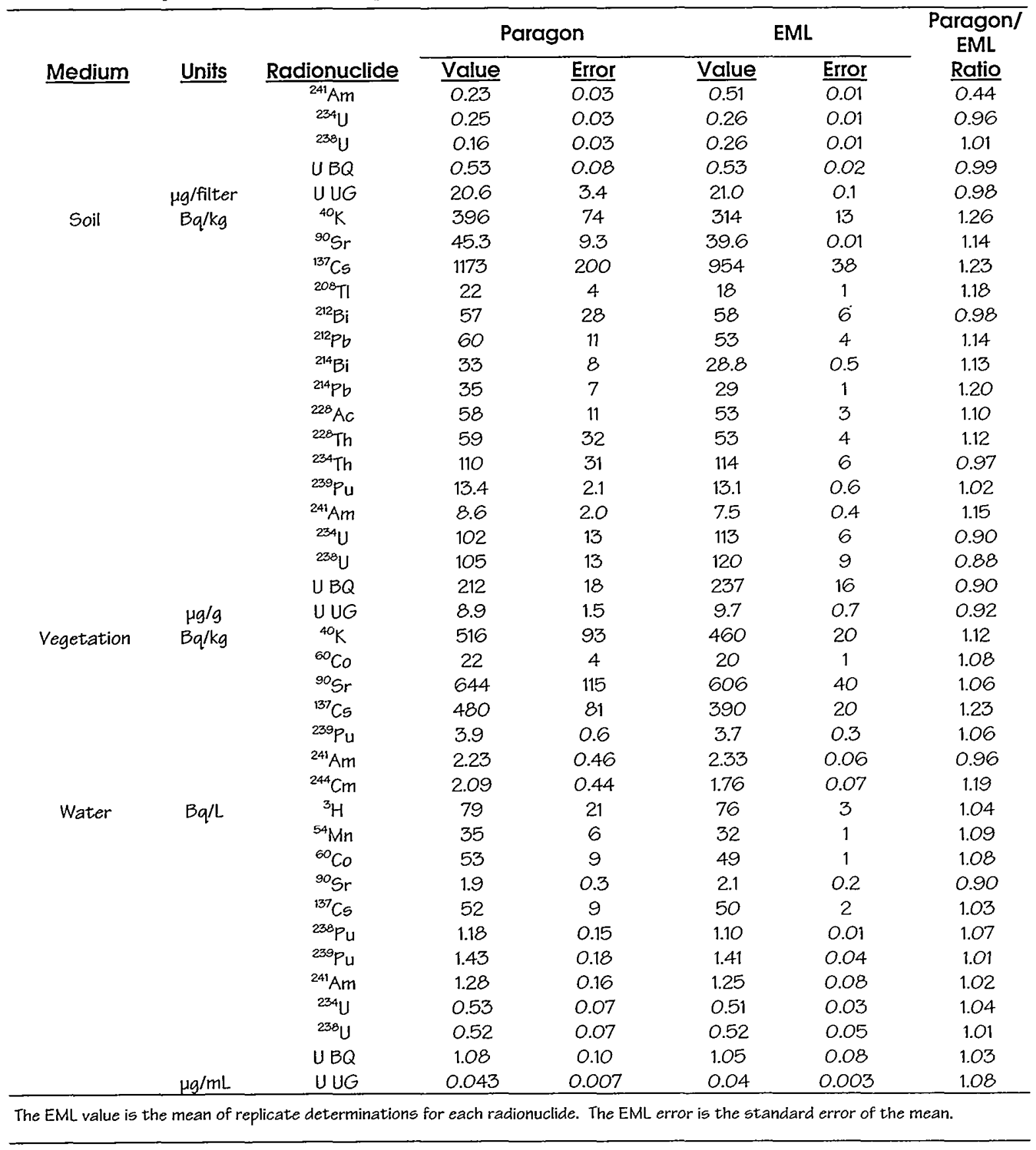


Table 9-5. Environmental Measurements Laboratory (EML) Quality Assessment Program Results For Quanterra, Inc. (1998)

\begin{tabular}{|c|c|c|c|c|c|c|c|}
\hline \multirow[b]{2}{*}{ Medium } & \multirow[b]{2}{*}{$\underline{\text { Units }}$} & \multirow[b]{2}{*}{$\underline{\text { Radionuclide }}$} & \multicolumn{2}{|c|}{ Quanterra } & \multicolumn{2}{|c|}{ EML } & \multirow{2}{*}{$\begin{array}{c}\text { Quanterra } \\
\text { /EML } \\
\text { Ratio }\end{array}$} \\
\hline & & & Value & Error & Value & Error & \\
\hline \multicolumn{8}{|c|}{ June Distribution } \\
\hline \multirow[t]{14}{*}{ Air } & $\mathrm{Bq} /$ filter & Gross alpha & 1.56 & 0.05 & 1.4 & 0.1 & 1.11 \\
\hline & & Gross beta & 2.32 & 0.04 & 2.0 & 0.3 & 1.18 \\
\hline & & ${ }^{54} \mathrm{Mn}$ & 5.8 & 0.2 & 5.4 & 0.5 & 1.06 \\
\hline & & ${ }^{57} \mathrm{Co}$ & 10.3 & 0.5 & 11.1 & 0.8 & 0.93 \\
\hline & & ${ }^{60} \mathrm{Co}$ & 8.5 & 0.2 & 9.1 & 0.7 & 0.94 \\
\hline & & ${ }^{90} \mathrm{Sr}$ & 1.75 & 0.15 & 1.76 & 0.04 & 0.99 \\
\hline & & ${ }^{125} \mathrm{Sb}$ & 13 & 1 & 12.2 & 1.2 & 1.05 \\
\hline & & ${ }^{134} \mathrm{Cs}$ & 17.5 & 0.6 & 20 & 1 & 0.89 \\
\hline & & ${ }^{137} \mathrm{Cs}$ & 11.0 & 0.1 & 11.9 & 1.0 & 0.93 \\
\hline & & ${ }^{144} \mathrm{Ce}$ & 7.5 & 0.4 & 8.2 & 0.8 & 0.91 \\
\hline & & ${ }^{238} \mathrm{Pu}$ & 0.07 & 0.01 & 0.07 & 0.003 & 1.00 \\
\hline & & ${ }^{239} \mathrm{Pu}$ & 0.064 & 0.01 & 0.062 & 0.002 & 1.03 \\
\hline & & ${ }^{241} \mathrm{Am}$ & 0.074 & 0.006 & 0.069 & 0.003 & 1.08 \\
\hline & $\mu g / f i l t e r$ & UUG & 2.69 & 0.01 & 2.5 & 0.1 & 1.09 \\
\hline \multirow[t]{8}{*}{ Soil } & $\mathrm{Bq} / \mathrm{kg}$ & ${ }^{40} \mathrm{~K}$ & 350 & 20 & 314 & 10 & 1.12 \\
\hline & & ${ }^{90} \mathrm{Sr}$ & 13.6 & 0.9 & 13.1 & 0.3 & 1.04 \\
\hline & & ${ }^{137} \mathrm{Cs}$ & 372 & 6 & 330 & 9 & 1.13 \\
\hline & & ${ }^{239} \mathrm{Pu}$ & 5.4 & 0.5 & 5.3 & 0.3 & 1.01 \\
\hline & & ${ }^{241} \mathrm{Am}$ & 2.7 & 0.3 & 2.7 & 0.2 & 1.00 \\
\hline & & ${ }^{234} U$ & 29.1 & 3.3 & 31.1 & 0.8 & 0.94 \\
\hline & & ${ }^{238} \mathrm{U}$ & 30.5 & 0.5 & 32 & 3 & 0.96 \\
\hline & $\mu g / g$ & UUG & 2.28 & 0.04 & 2.6 & 0.2 & 0.88 \\
\hline \multirow[t]{7}{*}{ Vegetation } & $\mathrm{Bq} / \mathrm{kg}$ & ${ }^{40} \mathrm{~K}$ & 811 & 5 & 708 & 25 & 1.15 \\
\hline & & ${ }^{60} \mathrm{Co}$ & 13.5 & 0.5 & 10.6 & 0.2 & 1.28 \\
\hline & & ${ }^{90} \mathrm{Sr}$ & 380 & 17 & 359 & 6 & 1.06 \\
\hline & & ${ }^{137} \mathrm{Cs}_{5}$ & 202 & 4 & 182 & 7 & 1.11 \\
\hline & & ${ }^{239} \mathrm{Pu}$ & 1.67 & 0.24 & 1.8 & 0.2 & 0.94 \\
\hline & & ${ }^{241} \mathrm{Am}$ & 1.29 & 0.25 & 1.11 & 0.05 & 1.17 \\
\hline & & ${ }^{244} \mathrm{Cm}$ & 1.59 & 0.16 & 2.17 & 0.07 & 0.73 \\
\hline \multirow[t]{14}{*}{ Water } & $\mathrm{Bq} / \mathrm{L}$ & Gross alpha & 1262 & 32 & 1421 & 100 & 0.89 \\
\hline & & Gross beta & 2007 & 245 & 2200 & 100 & 0.91 \\
\hline & & ${ }^{3} \mathrm{H}$ & 238 & 2 & 218 & 7 & 1.09 \\
\hline & & ${ }^{54} \mathrm{Mn}$ & 65 & 4 & 57 & 2 & 1.15 \\
\hline & & ${ }^{60} \mathrm{Co}$ & 16 & 3 & 13.6 & 1.2 & 1.18 \\
\hline & & ${ }^{90} \mathrm{Sr}$ & 5.0 & 0.2 & 4.4 & 0.2 & 1.15 \\
\hline & & ${ }^{137} \mathrm{Cs}$ & 52.1 & 0.7 & 46 & 2 & 1.13 \\
\hline & & ${ }^{238} \mathrm{Pu}$ & 2.42 & 0.17 & 2.53 & 0.06 & 0.96 \\
\hline & & ${ }^{239} \mathrm{Pu}$ & 1.66 & 0.17 & 1.65 & 0.06 & 1.01 \\
\hline & & ${ }^{241} \mathrm{Am}$ & 1.12 & 0.06 & 1.23 & 0.05 & 0.91 \\
\hline & & ${ }^{234} \mathrm{U}$ & 0.45 & 0.04 & 0.40 & 0.03 & 1.14 \\
\hline & & ${ }^{238} \mathrm{U}$ & 0.43 & 0.01 & 0.40 & 0.04 & 1.09 \\
\hline & $\mu \mathrm{g} / \mathrm{mL}$ & UUG & 0.0333 & 0.0002 & 0.032 & 0.003 & 1.04 \\
\hline & & & \multicolumn{2}{|c|}{ December Distribution } & & & \\
\hline \multirow[t]{8}{*}{ Air } & Bq/filter & Gross alpha & 1.96 & 0.03 & 1.65 & 0.16 & 1.19 \\
\hline & & Gross beta & 2.2 & 0.07 & 2.16 & 0.07 & 1.02 \\
\hline & & ${ }^{54} \mathrm{Mn}$ & 5.22 & 0.17 & 4.9 & 0.4 & 1.06 \\
\hline & & ${ }^{60} \mathrm{Co}$ & 8.82 & 0.33 & 9.2 & 0.6 & 0.96 \\
\hline & & ${ }^{90} \mathrm{Sr}$ & 1.09 & 0.12 & 1.1 & 0.05 & 0.97 \\
\hline & & ${ }^{125} \mathrm{Sb}$ & 9.1 & 0.5 & 8.9 & 0.6 & 1.02 \\
\hline & & ${ }^{137} \mathrm{Cs}$ & 21.8 & 0.3 & 23 & 1 & 0.97 \\
\hline & & ${ }^{238} \mathrm{Pu}$ & 0.5 & 0.03 & 0.46 & 0.01 & 1.09 \\
\hline
\end{tabular}


Table 9-5 (Continued). Environmental Measurements Laboratory (EML) Quality Assessment Program Results For Quanterra, Inc. (1998)

\begin{tabular}{|c|c|c|c|c|c|c|c|}
\hline \multirow[b]{2}{*}{ Medium } & \multirow[b]{2}{*}{ Units } & \multirow[b]{2}{*}{ Radionuclide } & \multicolumn{2}{|c|}{ Quanterra } & \multicolumn{2}{|c|}{ EML } & \multirow{2}{*}{$\begin{array}{c}\text { Quanterra } \\
\text { /EML } \\
\text { Ratio }\end{array}$} \\
\hline & & & Value & Error & Value & Error & \\
\hline \multirow{26}{*}{ Soil } & & ${ }^{239} \mathrm{Pu}$ & 0.48 & 0.02 & 0.42 & 0.01 & $\frac{1.14}{14}$ \\
\hline & & ${ }^{241} \mathrm{Am}$ & 0.46 & 0.07 & 0.51 & 0.01 & 0.90 \\
\hline & & ${ }^{234} U$ & 0.24 & 0.01 & 0.26 & 0.01 & 0.92 \\
\hline & & ${ }^{238} \mathrm{U}$ & 0.23 & 0.01 & 0.26 & 0.01 & 0.89 \\
\hline & & $U B Q$ & 0.49 & 0.02 & 0.53 & 0.02 & 0.93 \\
\hline & $\mu g / f i l t e r$ & UUG & 20.4 & 0.5 & 21.0 & 0.1 & 0.97 \\
\hline & $\mathrm{Bq} / \mathrm{kg}$ & ${ }^{4 O} \mathrm{~K}$ & 373 & 22 & 314 & 13 & 1.19 \\
\hline & & ${ }^{90} \mathrm{Sr}$ & 43 & 2.4 & 39.6 & 0.01 & 1.09 \\
\hline & & ${ }^{137} \mathrm{Cs}_{5}$ & 1129 & 46.0 & 954 & 38 & 1.18 \\
\hline & & ${ }^{208} \mathrm{TI}$ & 20.3 & 2.2 & 18 & 1 & 1.11 \\
\hline & & ${ }^{210} \mathrm{~Pb}$ & 41 & 3.0 & 32 & 3.3 & 1.28 \\
\hline & & ${ }^{212} \mathrm{Bi}$ & 61 & 3.0 & 58 & 6 & 1.05 \\
\hline & & ${ }^{212} \mathrm{~Pb}$ & 61 & 1.5 & 53 & 4 & 1.16 \\
\hline & & ${ }^{214} \mathrm{Bi}$ & 32 & 3.0 & 28.8 & 0.5 & 1.11 \\
\hline & & ${ }^{214} \mathrm{~Pb}$ & 35 & 1.5 & 29 & 1 & 1.20 \\
\hline & & ${ }^{226} \mathrm{Ra}$ & 32 & 3.0 & 29 & 1.0 & 1.10 \\
\hline & & ${ }^{228} \mathrm{AC}$ & 62 & 1.8 & 53 & 3 & 1.18 \\
\hline & & ${ }^{228} \mathrm{Th}$ & 57 & 7 & 53 & 4 & 1.08 \\
\hline & & ${ }^{234} \mathrm{Th}$ & 236 & 13 & 114 & 6 & 2.07 \\
\hline & & ${ }^{238} \mathrm{Pu}$ & 0.77 & 0.08 & 0.53 & 0.27 & 1.45 \\
\hline & & ${ }^{239} \mathrm{Pu}$ & 14.5 & 1.2 & 13.1 & 0.6 & 1.11 \\
\hline & & ${ }^{241} \mathrm{Am}$ & 4.88 & 0.76 & 7.5 & 0.4 & 0.65 \\
\hline & & ${ }^{234} U$ & 92 & 4 & 113 & 6 & 0.81 \\
\hline & & ${ }^{238} \mathrm{U}$ & 98 & 7 & 120 & 9 & 0.82 \\
\hline & & $U B Q$ & 193 & 13 & 237 & 16 & 0.81 \\
\hline & $\mu g / g$ & UUG & 10.2 & 0.5 & 9.7 & 0.7 & 1.05 \\
\hline \multirow[t]{6}{*}{ Vegetation } & $\mathrm{Bq} / \mathrm{kg}$ & $40 K$ & 567 & 8 & 460 & 20 & 1.23 \\
\hline & & ${ }^{60} \mathrm{Co}$ & 24.7 & 2.4 & 20 & 1 & 1.24 \\
\hline & & ${ }^{137} \mathrm{Cs}$ & 486 & 20 & 390 & 20 & 1.25 \\
\hline & & ${ }^{239} \mathrm{Pu}$ & 3.93 & 0.17 & 3.7 & 0.3 & 1.06 \\
\hline & & ${ }^{241} \mathrm{Am}$ & 2.2 & 0.24 & 2.33 & 0.06 & 0.94 \\
\hline & & ${ }^{244} \mathrm{Cm}$ & 1.94 & 0.11 & 1.76 & 0.07 & 1.10 \\
\hline \multirow[t]{14}{*}{ Water } & $\mathrm{Bq} / \mathrm{L}$ & Gross alpha & 933 & 4 & 1080 & 60 & 0.86 \\
\hline & & Gross beta & 1182 & 2 & 1420 & 60 & 0.83 \\
\hline & & ${ }^{3} \mathrm{H}$ & 79 & 5 & 76 & 3 & 1.04 \\
\hline & & ${ }^{54} \mathrm{Mn}$ & 35.8 & 1.5 & 32 & 1 & 1.11 \\
\hline & & ${ }^{60} \mathrm{Co}$ & 53.4 & 3.0 & 49 & 1 & 1.08 \\
\hline & & ${ }^{90} \mathrm{Sr}$ & 2.24 & 0.3 & 2.1 & 0.2 & 1.06 \\
\hline & & ${ }^{137} \mathrm{Cs}_{5}$ & 51.8 & 2.5 & 50 & 2 & 1.04 \\
\hline & & ${ }^{238} \mathrm{Pu}$ & 1.27 & 0.03 & 1.10 & 0.01 & 1.16 \\
\hline & & ${ }^{239} \mathrm{pu}$ & 1.58 & 0.12 & 1.41 & 0.04 & 1.12 \\
\hline & & ${ }^{241} \mathrm{Am}$ & 1.41 & 0.08 & 1.25 & 0.08 & 1.13 \\
\hline & & ${ }^{234} U$ & 0.5 & 0.01 & 0.51 & 0.03 & 0.98 \\
\hline & & ${ }^{238} U$ & 0.53 & 0.08 & 0.52 & 0.05 & 1.02 \\
\hline & & $\cup B Q$ & 1.05 & 0.1 & 1.05 & 0.08 & 1.00 \\
\hline & $\mu g / m L$ & UUG & 0.0399 & 0.0004 & 0.04 & 0.003 & 1.00 \\
\hline
\end{tabular}

The EML value is the mean of replicate determinations for each radionuclide. The EML error is the standard error of the mean. 
Table 9-6. Comparison of Duplicate Air Monitoring Results (1998)

\section{Environmental Science and Research Foundation Data}

\begin{tabular}{|c|c|c|c|c|c|c|c|c|}
\hline \multirow[b]{3}{*}{ Month } & \multicolumn{4}{|c|}{ Gross Alpha $\left(10^{-15} \mu \mathrm{Ci} / \mathrm{mL}\right)$} & \multicolumn{4}{|c|}{ Gross Beta $\left(10^{-15} \mu \mathrm{Ci} / \mathrm{mL}\right)$} \\
\hline & \multicolumn{2}{|c|}{ Reno Ranch } & \multicolumn{2}{|c|}{ Arco } & \multicolumn{2}{|c|}{ Reno Ranch } & \multicolumn{2}{|c|}{ Arco } \\
\hline & Sampler & Duplicate & Sampler & Duplicate & Sampler & Duplicate & Sampler & Duplicate \\
\hline$\overline{\text { January }}$ & $\overline{0.9 \pm 0.5}$ & $\overline{0.7 \pm 0.2}$ & $0.7 \pm 0.3$ & $0.7 \pm 0.4$ & $19 \pm 7$ & $17 \pm 5$ & $16 \pm 5$ & $18 \pm 9$ \\
\hline February & $0.7 \pm 0.4$ & $0.6 \pm 0.4$ & $1.0 \pm 0.6$ & $0.8 \pm 0.5$ & $17 \pm 6$ & $17 \pm 5$ & $18 \pm 5$ & $18 \pm 5$ \\
\hline March & $1.4 \pm 0.3$ & $0.7 \pm 0.5$ & $1.2 \pm 0.4$ & $1.1 \pm 0.6$ & $24 \pm 5$ & $22 \pm 8$ & $19 \pm 6$ & $19 \pm 6$ \\
\hline April & $1.4 \pm 0.3$ & $1.1 \pm 0.3$ & $1.6 \pm 0.7$ & $1.1 \pm 0.5$ & $19 \pm 3$ & $19 \pm 3$ & $18 \pm 4$ & $18 \pm 3$ \\
\hline May & $1.4 \pm 1.0$ & $0.7 \pm 0.5$ & $1.3 \pm 0.7$ & $1.2 \pm 0.6$ & $20 \pm 8$ & $20 \pm 8$ & $19 \pm 7$ & $17 \pm 7$ \\
\hline June & $0.7 \pm 0.4$ & $1.0 \pm 0.4$ & $0.9 \pm 0.3$ & $0.8 \pm 0.7$ & $15 \pm 2$ & $15 \pm 2$ & $15 \pm 1$ & $13 \pm 3$ \\
\hline July & $1.4 \pm 0.2$ & $1.9 \pm 0.4$ & $1.1 \pm 0.3$ & $1.9 \pm 1.0$ & $31 \pm 4$ & $31 \pm 2$ & $28 \pm 8$ & $27 \pm 4$ \\
\hline August & $1.7 \pm 0.5$ & $1.9 \pm 0.9$ & $1.7 \pm 0.4$ & $1.6 \pm 0.5$ & $31 \pm 4$ & $29 \pm 5$ & $29 \pm 5$ & $27 \pm 5$ \\
\hline September & $1.5 \pm 0.6$ & $1.3 \pm 0.4$ & $1.3 \pm 0.8$ & $1.2 \pm 0.4$ & $27 \pm 7$ & $27 \pm 8$ & $26 \pm 5$ & $24 \pm 4$ \\
\hline October & $1.8 \pm 0.5$ & $1.5 \pm 0.5$ & $2.4 \pm 0.8$ & $1.5 \pm 0.5$ & $28 \pm 13$ & $16 \pm 10$ & $27 \pm 13$ & $24 \pm 12$ \\
\hline November & $1.1 \pm 0.4$ & $1.2 \pm 0.5$ & $1.7 \pm 0.8$ & $2.0 \pm 2.2$ & $22 \pm 7$ & $23 \pm 9$ & $24 \pm 8$ & $18 \pm 4$ \\
\hline December & $0.6 \pm 0.4$ & $0.6 \pm 0.3$ & $1.2 \pm 0.8$ & $1.2 \pm 0.8$ & $25 \pm 11$ & $25 \pm 11$ & $26 \pm 12$ & $25 \pm 9$ \\
\hline Annual & $1.2 \pm 0.3$ & $1.1 \pm 0.3$ & $1.3 \pm 0.3$ & $1.3 \pm 0.3$ & $23 \pm 3$ & $22 \pm 3$ & $22 \pm 3$ & $21 \pm 3$ \\
\hline
\end{tabular}

\section{INEEL M\&O Contractor Data}

\begin{tabular}{|c|c|c|c|c|c|c|c|c|}
\hline \multirow[b]{3}{*}{ Month } & \multicolumn{4}{|c|}{ Gross Alpha $\left(10^{-15} \mu \mathrm{Ci} / \mathrm{mL}\right)$} & \multicolumn{4}{|c|}{ Gross Beta $\left(10^{-15} \mu \mathrm{Ci} / \mathrm{ml}\right)$} \\
\hline & \multicolumn{2}{|c|}{ CFA } & \multicolumn{2}{|c|}{ TAN } & \multicolumn{2}{|c|}{ CFA } & \multicolumn{2}{|c|}{ IAN } \\
\hline & Sampler & Duplicałe & Sampler & Duplicate & Sampler & Duplicate & Sampler & Duplicate \\
\hline January & $0.4 \pm 0.7$ & $0.5 \pm 1.0$ & $0.5 \pm 0.7$ & $0.5 \pm 0.6$ & $16 \pm 9$ & $22 \pm 14$ & $19 \pm 12$ & $20 \pm 10$ \\
\hline February & $-0.0 \pm 0.9$ & $0.3 \pm 0.7$ & $0.4 \pm 1.0$ & $0.1 \pm 0.9$ & $15 \pm 7$ & $19 \pm 14$ & $20 \pm 12$ & $19 \pm 13$ \\
\hline March & $-0.2 \pm 0.5$ & $0.1 \pm 0.9$ & $1.1 \pm 0.4$ & $0.7 \pm 0.8$ & $10 \pm 6$ & $13 \pm 7$ & $15 \pm 4$ & $17 \pm 4$ \\
\hline April & $0.8 \pm 0.3$ & $0.3 \pm 0.3$ & $1.1 \pm 0.5$ & $0.5 \pm 0.6$ & $16 \pm 5$ & $15 \pm 2$ & $16 \pm 2$ & $16 \pm 1$ \\
\hline May & $1.0 \pm 0.8$ & $0.7 \pm 1.0$ & $1.6 \pm 0.3$ & $1.3 \pm 0.4$ & $18 \pm 6$ & $21 \pm 8$ & $20 \pm 5$ & $19 \pm 4$ \\
\hline June & $0.8 \pm 0.8$ & $1.0 \pm 0.8$ & $0.8 \pm 0.3$ & $0.5 \pm 0.7$ & $16 \pm 4$ & $22 \pm 2$ & $19 \pm 1$ & $18 \pm 3$ \\
\hline July & $0.5 \pm 0.8$ & $1.1 \pm 1.0$ & $1.0 \pm 0.5$ & $0.4 \pm 0.5$ & $22 \pm 6$ & $15 \pm 4$ & $23 \pm 5$ & $21 \pm 4$ \\
\hline August & $0.9 \pm 0.3$ & $0.7 \pm 0.5$ & $1.5 \pm 0.7$ & $1.0 \pm 0.4$ & $22 \pm 6$ & $23 \pm 1$ & $24 \pm 2$ & $23 \pm 6$ \\
\hline September & $0.5 \pm 0.9$ & $1.1 \pm 1.3$ & $1.0 \pm 1.0$ & $1.3 \pm 0.3$ & $17 \pm 5$ & $22 \pm 5$ & $18 \pm 5$ & $20 \pm 5$ \\
\hline October & $0.9 \pm 1.3$ & $2.1 \pm 1.1$ & $1.2 \pm 0.4$ & $1.3 \pm 0.8$ & $24 \pm 10$ & $25 \pm 12$ & $23 \pm 9$ & $26 \pm 9$ \\
\hline November & $0.7 \pm 0.7$ & $0.9 \pm 0.9$ & $1.5 \pm 0.8$ & $1.2 \pm 0.5$ & $28 \pm 11$ & $27 \pm 11$ & $22 \pm 6$ & $26 \pm 11$ \\
\hline December & $1.1 \pm 0.6$ & $0.7 \pm 0.8$ & $-0.1 \pm 0.2$ & $0.4 \pm 0.3$ & $26 \pm 3$ & $24 \pm 5$ & $27 \pm 5$ & $28 \pm 5$ \\
\hline Annual & $0.6 \pm 0.3$ & $0.8 \pm 0.3$ & $1.0 \pm 0.3$ & $0.8 \pm 0.3$ & $19 \pm 3$ & $21 \pm 3$ & $21 \pm 2$ & $21 \pm 2$ \\
\hline
\end{tabular}


Table 9-7. Comparison of Foundation (F), INEEL M\&O Contractor (M\&O) and State of Idaho (S) Air Monitoring Results - Gross Alpha (1998)

\begin{tabular}{|c|c|c|c|c|c|c|c|c|c|}
\hline \multirow{3}{*}{$\begin{array}{l}\text { Week } \\
\text { Ending }\end{array}$} & \multicolumn{9}{|c|}{ Gross Alpha $\left(10^{-15} \mu \mathrm{Ci} / \mathrm{mL}\right)$} \\
\hline & \multicolumn{3}{|c|}{ Craters of the Moon } & \multicolumn{3}{|c|}{ EFS } & \multicolumn{3}{|c|}{ Van Buren } \\
\hline & $\underline{\mathbf{F}}$ & $\mathrm{M \& O}$ & $\underline{\mathbf{S}}$ & $\underline{F}$ & $\overline{\mathrm{M} \& O}$ & $\underline{\mathbf{S}}$ & $\underline{F}$ & $\underline{M \& O}$ & $\underline{\mathbf{S}}$ \\
\hline $1 / 9$ & $0.5 \pm 0.6$ & $0.1 \pm 0.4$ & $7.5 \pm 1.5$ & $0.8 \pm 0.6$ & $0 . \overline{3 \pm 0.4}$ & $10.9 \pm 1.8$ & $0.1 \pm 0.5$ & $0.2 \pm 0.5$ & $7.8 \pm 1.5$ \\
\hline $1 / 16$ & $0.6 \pm 0.4$ & $0.0 \pm 0.7$ & $2.4 \pm 1.0$ & $0.2 \pm 0.3$ & $0.3 \pm 0.9$ & $4.1 \pm 1.2$ & $0.7 \pm 0.5$ & $-0.7 \pm 1.0$ & $3.3 \pm 1.4$ \\
\hline $1 / 23$ & $0.3 \pm 0.3$ & $-0.6 \pm 0.8$ & $2.1 \pm 1.0$ & $0.9 \pm 0.5$ & $-0.6 \pm 1.0$ & $3.8 \pm 1.2$ & $0.4 \pm 0.4$ & $-0.6 \pm 1.0$ & $2.7 \pm 1.1$ \\
\hline $1 / 30$ & $0.9 \pm 0.5$ & $-0.4 \pm 0.7$ & $4.8 \pm 1.3$ & $0.4 \pm 0.5$ & $1.6 \pm 1.0$ & $9.6 \pm 1.7$ & $0.9 \pm 0.6$ & $0.2 \pm 0.5$ & $8.4 \pm 1.6$ \\
\hline 216 & $1.2 \pm 0.5$ & $1.0 \pm 0.7$ & $7.1 \pm 1.6$ & $0.6 \pm 0.4$ & $-0.2 \pm 0.7$ & $8.4 \pm 1.7$ & $0.9 \pm 0.5$ & $0.7 \pm 0.9$ & $7.0 \pm 1.6$ \\
\hline $2 / 13$ & $0.3 \pm 0.4$ & $0.3 \pm 0.6$ & $3.2 \pm 1.1$ & $0.1 \pm 0.4$ & $-0.4 \pm 0.7$ & $2.6 \pm 1.0$ & $0.7 \pm 0.8$ & $-0.3 \pm 0.8$ & $4.3 \pm 1.2$ \\
\hline $2 / 20$ & $0.1 \pm 0.6$ & $-0.7 \pm 0.5$ & $0.8 \pm 0.7$ & $0.7 \pm 0.5$ & $-0.3 \pm 0.7$ & $0.9 \pm 0.7$ & $0.8 \pm 0.5$ & $-0.9 \pm 0.7$ & $0.9 \pm 0.7$ \\
\hline $2 / 27$ & $0.4 \pm 0.5$ & $1.1 \pm 0.7$ & $2.5 \pm 1.0$ & $0.3 \pm 0.4$ & $1.6 \pm 0.8$ & $4.1 \pm 1.2$ & $0.8 \pm 0.5$ & $1.4 \pm 1.0$ & $3.6 \pm 1.2$ \\
\hline $3 / 6$ & $0.0 \pm 0.5$ & $-0.4 \pm 0.7$ & $1.4 \pm 0.9$ & $0.1 \pm 0.5$ & $0.2 \pm 0.8$ & $1.3 \pm 0.9$ & $0.7 \pm 0.7$ & $1.0 \pm 1.0$ & $1.6 \pm 0.9$ \\
\hline $3 / 13$ & $0.5 \pm 0.5$ & $-0.6 \pm 0.6$ & $1.7 \pm 0.9$ & $0.5 \pm 0.5$ & $0.9 \pm 0.9$ & $1.4 \pm 0.9$ & $0.9 \pm 0.6$ & $-0.3 \pm 0.0$ & $2.8 \pm 11$ \\
\hline $3 / 20$ & $1.1 \pm 0.5$ & $-0.4 \pm 0.7$ & $1.2 \pm 0.9$ & $0.9 \pm 0.5$ & $0.3 \pm 0.9$ & $1.6 \pm 0.9$ & $1.2 \pm 0.6$ & $0.0 \pm 1.0$ & $1.2 \pm 0.9$ \\
\hline $3 / 27$ & $0.4 \pm 0.5$ & $0.0 \pm 0.6$ & $0.3 \pm 0.8$ & $1.2 \pm 0.7$ & $1.9 \pm 0.9$ & $0.4 \pm 0.8$ & $0.8 \pm 0.7$ & $0.9 \pm 1.0$ & $0.1 \pm 0.8$ \\
\hline $4 / 3$ & $0.5 \pm 0.5$ & $-1.4 \pm 0.6$ & $2.1 \pm 1.1$ & $0.6 \pm 0.5$ & $-0.8 \pm 0.8$ & $2.9 \pm 1.2$ & $0.0 \pm 0.5$ & $0.0 \pm 0.9$ & $1.4 \pm 1.0$ \\
\hline $4 / 10$ & $0.3 \pm 1.1$ & $-0.2 \pm 0.6$ & $0.8 \pm 0.3$ & $0.1 \pm 1.1$ & $1.1 \pm 0.8$ & $0.9 \pm 0.3$ & $0.8 \pm 1.4$ & $1.2 \pm 1.0$ & $0.8 \pm 0.3$ \\
\hline $4 / 17$ & $0.9 \pm 0.5$ & $0.8 \pm 0.7$ & $1.1 \pm 0.4$ & $0.8 \pm 0.4$ & $1.3 \pm 0.9$ & $1.1 \pm 0.4$ & $1.6 \pm 0.6$ & $0.6 \pm 0.9$ & $1.4 \pm 0.4$ \\
\hline $4 / 24$ & $1.3 \pm 0.6$ & $-0.4 \pm 0.7$ & $2.1 \pm 0.5$ & $1.2 \pm 0.5$ & $1.9 \pm 1.0$ & $2.9 \pm 0.5$ & $1.7 \pm 0.7$ & $1.0 \pm 1.3$ & $2.6 \pm 0.5$ \\
\hline $5 / 1$ & $1.4 \pm 0.7$ & $0.8 \pm 0.8$ & $2.5 \pm 0.5$ & $1.6 \pm 0.7$ & $4.4 \pm 1.3$ & $2.6 \pm 0.5$ & $1.5 \pm 0.7$ & $-0.4 \pm 0.9$ & $2.6 \pm 0.5$ \\
\hline $5 / 8$ & $1.6 \pm 0.7$ & $1.1 \pm 0.7$ & $3.3 \pm 0.5$ & $2.4 \pm 0.8$ & $3.9 \pm 1.2$ & $3.4 \pm 0.5$ & $2.3 \pm 0.8$ & $1.9 \pm 1.2$ & $3.4 \pm 0.5$ \\
\hline $5 / 15$ & $1.0 \pm 0.5$ & $-0.4 \pm 0.7$ & $0.7 \pm 0.3$ & $0.7 \pm 0.5$ & $0.6 \pm 1.0$ & $1.2 \pm 0.4$ & $1.4 \pm 0.6$ & $1.1 \pm 1.0$ & $1.1 \pm 0.4$ \\
\hline $5 / 22$ & $0.7 \pm 0.4$ & $0.1 \pm 0.7$ & $0.4 \pm 0.3$ & $0.7 \pm 0.4$ & $-0.3 \pm 0.9$ & $0.7 \pm 0.3$ & $1.2 \pm 0.6$ & $0.6 \pm 1.2$ & $0.6 \pm 0.3$ \\
\hline $5 / 29$ & $1.1 \pm 0.5$ & $0.0 \pm 0.7$ & $1.0 \pm 0.3$ & $0.8 \pm 0.4$ & $0.0 \pm 0.9$ & $0.8 \pm 0.3$ & $1.7 \pm 0.6$ & $-0.9 \pm 0.9$ & $0.8 \pm 0.3$ \\
\hline $6 / 5$ & $0.9 \pm 0.8$ & $0.5 \pm 0.7$ & $0.6 \pm 0.3$ & $0.7 \pm 0.5$ & $0.0 \neq 0.8$ & $0.6 \pm 0.3$ & $0.9 \pm 0.6$ & $2.2 \pm 1.2$ & $0.7 \pm 03$ \\
\hline $6 / 12$ & $0.2 \pm 1.0$ & $-1.1 \pm 0.6$ & $0.8 \pm 0.3$ & $0.6 \pm 1.0$ & $0.2 \pm 0.8$ & $0.9 \pm 0.3$ & $-0.3 \pm 1.3$ & $-0.9 \pm 1.0$ & $0.7 \pm 0.3$ \\
\hline $6 / 19$ & $1.0 \pm 0.5$ & $-0.3 \pm 0.6$ & $0.3 \pm 0.2$ & $0.3 \pm 0.3$ & $1.5 \pm 0.9$ & NS & $0.6 \pm 0.4$ & $0.8 \pm 1.1$ & $0.4 \pm 0.3$ \\
\hline $6 / 26$ & $0.6 \pm 0.4$ & $0.2 \pm 0.7$ & $0.8 \pm 0.3$ & $0.5 \pm 0.4$ & $0.2 \pm 0.9$ & $0.7 \pm 0.3$ & $0.7 \pm 0.5$ & $-0.8 \pm 0.9$ & $0.6 \pm 0.3$ \\
\hline $7 / 3$ & $1.0 \pm 0.9$ & $-0.2 \pm 0.6$ & $0.5 \pm 0.3$ & $0.8 \pm 0.8$ & $0.8 \pm 0.7$ & $0.6 \pm 0.3$ & $0.8 \pm 1.0$ & $0.0 \pm 0.9$ & $1.0 \pm 0.3$ \\
\hline $7 / 10$ & $0.9 \pm 0.6$ & $-0.6 \pm 0.6$ & $1.3 \pm 0.3$ & $1.6 \pm 0.6$ & $0.4 \pm 0.9$ & $1.7 \pm 0.4$ & $0.6 \pm 0.4$ & $1.9 \pm 1.1$ & $1.2 \pm 0.3$ \\
\hline $7 / 17$ & $1.6 \pm 0.6$ & $1.2 \pm 0.7$ & $1.1 \pm 0.3$ & $1.5 \pm 0.6$ & $2.0 \pm 0.8$ & $1.7 \pm 0.4$ & $1.5 \pm 0.6$ & $0.8 \pm 0.9$ & $1.4 \pm 0.4$ \\
\hline $7 / 24$ & $0.8 \pm 0.5$ & $0.2 \pm 0.7$ & $0.8 \pm 0.3$ & $1.4 \pm 0.8$ & $0.4 \pm 0.9$ & $1.2 \pm 0.3$ & $1.7 \pm 0.7$ & $0.5 \pm 1.0$ & $1.2 \pm 0.3$ \\
\hline $7 / 31$ & $0.8 \pm 0.5$ & $0.8 \pm 0.6$ & $2.1 \pm 0.4$ & $1.5 \pm 0.6$ & $0.8 \pm 0.8$ & $3.1 \pm 0.5$ & $1.1 \pm 0.6$ & $0.9 \pm 1.0$ & $2.2 \pm 0.4$ \\
\hline 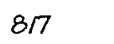 & $0.0 \pm 0.6$ & $1.4 \pm 0.7$ & $1.0 \pm 0.3$ & $2.0 \pm 0.6$ & $2.3 \pm 0.9$ & $2.1 \pm 0.4$ & $1.6 \pm 0.6$ & $2.8 \pm 1.1$ & $2.0 \pm 04$ \\
\hline $8 / 14$ & $0.8 \pm 0.5$ & $1.3 \pm 0.7$ & $0.9 \pm 0.4$ & $1.8 \pm 0.6$ & $0.5 \pm 0.8$ & $0.9 \pm 0.4$ & $1.8 \pm 0.7$ & $1.6 \pm 1.0$ & $0.9 \pm 04$ \\
\hline $8 / 21$ & $1.1 \pm 0.8$ & $0.4 \pm 0.7$ & $0.7 \pm 0.3$ & $1.6 \pm 0.6$ & $0.8 \pm 1.0$ & $1.2 \pm 0.4$ & NS & $3.4 \pm 1.2$ & $0.9 \pm 0.4$ \\
\hline $8 / 28$ & $0.3 \pm 0.9$ & $0.6 \pm 0.7$ & $0.9 \pm 0.3$ & $1.9 \pm 0.7$ & $3.0 \pm 1.0$ & $1.1 \pm 0.3$ & $1.7 \pm 0.7$ & $0.4 \pm 1.0$ & $1.0 \pm 0.3$ \\
\hline $9 / 4$ & NS & $2.1 \pm 0.9$ & $2.6 \pm 0.8$ & $1.9 \pm 0.8$ & $1.2 \pm 1.2$ & $2.9 \pm 0.5$ & $2.6 \pm 0.9$ & $1.4 \pm 1.3$ & $2.4 \pm 0.5$ \\
\hline $9 / 11$ & $1.1 \pm 1.5$ & $0.6 \pm 0.8$ & $0.9 \pm 0.4$ & $2.5 \pm 0.8$ & $2.5 \pm 1.1$ & $1.4 \pm 0.4$ & $2.4 \pm 0.9$ & $1.7 \pm 1.2$ & $1.0 \pm 04$ \\
\hline $9 / 18$ & $-0.4 \pm 1.1$ & $1.1 \pm 0.7$ & $1.1 \pm 0.4$ & $0.6 \pm 0.5$ & $1.3 \pm 0.9$ & $1.7 \pm 0.4$ & $0.1 \pm 0.9$ & $1.0 \pm 1.0$ & $1.5 \pm 0.4$ \\
\hline $9 / 25$ & $0.4 \pm 0.4$ & $-0.1 \pm 0.6$ & $1.0 \pm 0.3$ & $1.4 \pm 0.6$ & $1.2 \pm 0.9$ & $0.5 \pm 0.3$ & $1.1 \pm 0.5$ & $2.1 \pm 1.1$ & NS \\
\hline $10 / 2$ & $0.6 \pm 0.8$ & $0.3 \pm 0.7$ & $1.0 \pm 0.4$ & $0.6 \pm 0.6$ & $2.8 \pm 1.0$ & $0.9 \pm 0.3$ & $1.7 \pm 0.6$ & $0.7 \pm 0.9$ & $1.0 \pm 0.4$ \\
\hline $10 / 9$ & $1.1 \pm 0.5$ & $1.3 \pm 0.8$ & $0.0 \pm 0.4$ & $1.3 \pm 0.5$ & $1.6 \pm 1.0$ & $0.0 \pm 0.4$ & $0.7 \pm 0.3$ & $O . O \pm 1 . O$ & $0.7 \pm 05$ \\
\hline $10 / 16$ & $1.4 \pm 0.5$ & $0.8 \pm 0.8$ & $0.9 \pm 0.3$ & $2.5 \pm 0.7$ & $1.0 \pm 1.0$ & $1.3 \pm 0.4$ & $2.4 \pm 0.6$ & $1.7 \pm 1.1$ & $1.1 \pm 0.3$ \\
\hline $10 / 23$ & $0.7 \pm 0.4$ & $0.9 \pm 0.8$ & $0.8 \pm 0.3$ & $1.3 \pm 0.5$ & $1.6 \pm 0.9$ & $0.9 \pm 0.3$ & $1.2 \pm 0.5$ & $1.3 \pm 1.3$ & $0.8 \pm 0.3$ \\
\hline $10 / 30$ & $1.7 \pm 0.6$ & $0.4 \pm 1.2$ & $0.2 \pm 0.3$ & $1.9 \pm 0.7$ & $1.4 \pm 1.1$ & $1.6 \pm 0.4$ & $2.3 \pm 0.6$ & $0.5 \pm 1.3$ & $0.9 \pm 0.3$ \\
\hline $11 / 6$ & $1.0 \pm 0.4$ & $-0.8 \pm 1.1$ & $1.3 \pm 0.4$ & $2.2 \pm 0.7$ & $0.7 \pm 1.1$ & $1.9 \pm 0.4$ & $1.9 \pm 0.6$ & $2.7 \pm 1.5$ & $1.4 \pm 0.4$ \\
\hline $11 / 13$ & $1.2 \pm 0.8$ & $0.3 \pm 1.3$ & $0.6 \pm 0.2$ & $2.0 \pm 1.0$ & $-1.0 \pm 1.0$ & $0.7 \pm 0.2$ & $0.9 \pm 0.8$ & $1.7 \pm 1.3$ & $07 \pm 0.3$ \\
\hline $11 / 20$ & $0.5 \pm 0.4$ & $0.9 \pm 1.1$ & $0.9 \pm 0.3$ & $1.0 \pm 0.5$ & $1.6 \pm 1.2$ & $1.4 \pm 0.4$ & $1.2 \pm 0.5$ & $1.6 \pm 1.4$ & $1.0 \pm 0.3$ \\
\hline $11 / 27$ & $0.2 \pm 0.3$ & $-1.4 \pm 1.2$ & $0.4 \pm 0.2$ & $0.6 \pm 0.5$ & $0.0 \pm 1.3$ & $0.7 \pm 0.3$ & $0.6 \pm 0.8$ & $1.1 \pm 1.5$ & $02 \pm 0.2$ \\
\hline $12 / 4$ & $0.5 \pm 0.3$ & $0.4 \pm 1.0$ & $0.7 \pm 0.3$ & $1.0 \pm 0.4$ & $1.3 \pm 1.0$ & $0.7 \pm 0.3$ & $0.3 \pm 0.3$ & $0.7 \pm 1.1$ & $0.9 \pm 0.3$ \\
\hline $12 / 11$ & $0.1 \pm 0.3$ & $-0.3 \pm 1.3$ & $0.0 \pm 0.2$ & $0.1 \pm 0.3$ & $-0.7 \pm 1.2$ & $0.1 \pm 0.2$ & $-0.1 \pm 0.3$ & $-0.7 \pm 1.4$ & $0.1 \pm 02$ \\
\hline $12 / 18$ & $0.5 \pm 0.4$ & $0.4 \pm 1.2$ & $1.0 \pm 0.3$ & $0.7 \pm 0.4$ & $0.4 \pm 1.1$ & $1.0 \pm 0.3$ & $0.9 \pm 0.8$ & $-0.6 \pm 1.2$ & $0.7 \pm 0.3$ \\
\hline $12 / 25$ & $0.4 \pm 0.4$ & $-1.8 \pm 1.5$ & $1.0 \pm 0.3$ & $1.3 \pm 0.6$ & $-0.8 \pm 1.3$ & $1.0 \pm 0.3$ & $1.2 \pm 0.5$ & $0.0 \pm 1.6$ & $1.1 \pm 0.3$ \\
\hline $12 / 3 i$ & $1.2 \pm 0.5$ & NS & $0.8 \pm 0.3$ & $1.0 \pm 0.5$ & NS & $1.3 \pm 0.4$ & $-0.4 \pm 0.2$ & NS & $0.7 \pm 0.3$ \\
\hline
\end{tabular}


Table 9-8. Comparison of Foundation (F), INEEL M\&O Contractor (M\&O) and State of Idaho (S)

Air Monitoring Results-Gross Beta (1998)

\begin{tabular}{|c|c|c|c|c|c|c|c|c|c|}
\hline \multirow{3}{*}{$\begin{array}{l}\text { Week } \\
\text { Ending }\end{array}$} & \multicolumn{9}{|c|}{ Gross Beta $\left(10^{.15} \mu \mathrm{Ci} / \mathrm{mL}\right)$} \\
\hline & \multicolumn{3}{|c|}{ Craters of the Moon } & \multicolumn{3}{|c|}{ EFS } & \multicolumn{3}{|c|}{ Van Buren } \\
\hline & $\underline{F}$ & M\&O & $\underline{\mathbf{s}}$ & $\underline{\mathbf{F}}$ & $\overline{M \& O}$ & $\underline{\mathbf{s}}$ & $\underline{F}$ & $\mathrm{M} \& \mathrm{O}$ & $\underline{\mathbf{s}}$ \\
\hline$\sqrt[1 / 9]{9}$ & $15 \pm 2$ & $\overline{14 \pm 1}$ & $2 \overrightarrow{4 \pm} 4$ & $23^{-} \pm 2$ & $\overline{28 \pm 1}$ & $38 \pm 5$ & $22 \pm 2$ & $\overline{21 \pm 1}$ & $30 \pm 5$ \\
\hline $1 / 16$ & $9 \pm 1$ & $8 \pm 1$ & $12 \pm 4$ & $15 \pm 2$ & $14 \pm 2$ & $15 * 4$ & $15 \pm 2$ & $11 \pm 2$ & $19 \pm 5$ \\
\hline $1 / 23$ & $8 \pm 2$ & $7 \pm 1$ & $9 \pm 4$ & $9 \pm 2$ & $6 \pm 2$ & $16 \pm 4$ & $9 \pm 2$ & $7 \pm 2$ & $10 \pm 4$ \\
\hline $1 / 30$ & $13 \pm 2$ & $16 \pm 2$ & $20 \pm 4$ & $25 \pm 2$ & $19 \pm 2$ & $35 \pm 5$ & $23 \pm 2$ & $8 \pm 2$ & $27 \pm 5$ \\
\hline $2 / 6$ & $20 \pm 5$ & $18 \pm 2$ & $34 \pm 5$ & $23 \pm 2$ & $23 \pm 2$ & $36 \pm 5$ & $25 \pm 2$ & $20 \pm 2$ & $31 \pm 5$ \\
\hline $2 / 13$ & $10 \pm 2$ & $9 \pm 1$ & $13 \pm 4$ & $13 \pm 2$ & $10 \pm 2$ & $13 \pm 4$ & $12 \pm 2$ & $7 \pm 2$ & $14 \pm 4$ \\
\hline $2 / 20$ & $11 \pm 2$ & $10 \pm 1$ & $17 \pm 4$ & $14 \pm 2$ & $12 \pm 2$ & $18 \pm 4$ & $15 \pm 2$ & $9 \pm 2$ & $22 \pm 4$ \\
\hline $2 / 27$ & $10 \pm 2$ & $9 \pm 1$ & $20 \pm 4$ & $17 \pm 2$ & $13 \pm 2$ & $16 \pm 4$ & $17 \pm 2$ & $14 \pm 2$ & $16 \pm 4$ \\
\hline $3 / 6$ & $15 \pm 2$ & $10 \pm 1$ & $22 \pm 4$ & $16 \pm 2$ & $15 \pm 2$ & $24 \pm 4$ & $25 \pm 2$ & $11 \pm 2$ & $21 \pm 4$ \\
\hline $3 / 13$ & $18 \pm 2$ & $17 \pm 2$ & $38 \pm 5$ & $25 \pm 2$ & $16 \pm 2$ & $44 \pm 5$ & $25 \pm 2$ & $20 \pm 2$ & $43 \pm 5$ \\
\hline $3 / 20$ & $23 \pm 2$ & $21 \pm 2$ & $32 \pm 5$ & $31 \pm 2$ & $31 \pm 2$ & $36 \pm 5$ & $32 \pm 3$ & $29 \pm 2$ & $37 \pm 5$ \\
\hline $3 / 27$ & $17 \pm 2$ & $15 \pm 1$ & $24 \pm 4$ & $21 \pm 2$ & $22 \pm 2$ & $28 \pm 4$ & $22 \pm 2$ & $18 \pm 2$ & $24 \pm 4$ \\
\hline $4 / 3$ & $10 \pm 2$ & $10 \pm 1$ & $21 \pm 4$ & $13 \pm 2$ & $15 \pm 2$ & $25 \pm 5$ & $14 \pm 2$ & $11 \pm 2$ & $23 \pm 4$ \\
\hline $4 / 10$ & $13 \pm 2$ & $11 \pm 1$ & $18 \pm 1$ & $14 \pm 2$ & $16 \pm 2$ & $18 \pm 1$ & $18 \pm 3$ & $13 \pm 2$ & $19 \pm 1$ \\
\hline $4 / 17$ & $14 \pm 2$ & $10 \pm 1$ & $14 \pm 1$ & $14 \pm 2$ & $14 \pm 2$ & $17 \pm 1$ & $16 \pm 2$ & $9 \pm 2$ & $18 \pm 1$ \\
\hline $4 / 24$ & $23 \pm 2$ & $17 \pm 2$ & $31 \pm 2$ & $18 \pm 2$ & $26 \pm 2$ & $31 \pm 2$ & $24 \pm 2$ & $27 \pm 3$ & $31 \pm 2$ \\
\hline $5 / 1$ & $20 \pm 2$ & $14 \pm 2$ & $25 \pm 1$ & $23 \pm 2$ & $21 \pm 2$ & $26 \pm 1$ & $20 \pm 2$ & $15 \pm 2$ & $24 \pm 1$ \\
\hline $5 / 8$ & $29 \pm 2$ & $23 \pm 2$ & $38 \pm 2$ & $31 \pm 2$ & $34 \pm 3$ & $35 \pm 2$ & $33 \pm 3$ & $28 \pm 3$ & $37 \pm 2$ \\
\hline $5 / 15$ & $19 \pm 2$ & $17 \pm 2$ & $20 \pm 1$ & $18 \pm 2$ & $19 \pm 2$ & $20 \pm 1$ & $22 \pm 2$ & $12 \pm 2$ & $19 \pm 1$ \\
\hline $5 / 22$ & $9 \pm 1$ & $10 \pm 1$ & $18 \pm 1$ & $14 \pm 2$ & $12 \pm 2$ & $17 \pm 1$ & $15 \pm 2$ & $15 \pm 2$ & $18 \pm 1$ \\
\hline $5 / 29$ & $13 \pm 2$ & $11 \pm 2$ & $17 \pm 1$ & $16 \pm 2$ & $13 \pm 2$ & $16 \pm 1$ & $16 \pm 2$ & $14 \pm 2$ & $14 \pm 1$ \\
\hline $6 / 5$ & $14 \pm 2$ & $11 \pm 2$ & $16 \pm 1$ & $17 \pm 2$ & $12 \pm 2$ & $14 \pm 1$ & $14 \pm 2$ & $13 \pm 2$ & $16 \pm 1$ \\
\hline $6 / 12$ & $12 \pm 2$ & $10 \pm 2$ & $20 \pm 1$ & $14 \pm 2$ & $15 \pm 2$ & $19 \pm 1$ & $15 \pm 2$ & $13 \pm 2$ & $20 \pm 1$ \\
\hline $6 / 19$ & $16 \pm 2$ & $13 \pm 2$ & $17 \pm 1$ & $16 \pm 2$ & $20 \pm 2$ & NS & $19 \pm 2$ & $14 \pm 2$ & $17 \pm 1$ \\
\hline $6 / 26$ & $15 \pm 1$ & $11 \pm 2$ & $21 \pm 1$ & $14 \pm 1$ & $17 \pm 2$ & $23 \pm 1$ & $17 \pm 2$ & $16 \pm 2$ & $19 \pm 1$ \\
\hline $7 / 3$ & $14 \pm 2$ & $13 \pm 2$ & $21 \pm 1$ & $13 \pm 2$ & $18 \pm 2$ & $M \& O 25 \pm 1$ & $17 \pm 2$ & $13 \pm 2$ & $22 \pm 1$ \\
\hline $7 / 10$ & $27 \pm 2$ & $25 \pm 2$ & $40 \pm 2$ & $32 \pm 2$ & $31 \pm 2$ & $51 \pm 2$ & $17 \pm 2$ & $26 \pm 2$ & $42 \pm 2$ \\
\hline $7 / 17$ & $27 \pm 2$ & $21 \pm 2$ & $38 \pm 2$ & $31 \pm 2$ & $32 \pm 2$ & $41 \pm 2$ & $32 \pm 2$ & $30 \pm 2$ & $39 \pm 2$ \\
\hline $7 / 24$ & $24 \pm 2$ & $22 \pm 2$ & $42 \pm 2$ & $32 \pm 3$ & $37 \pm 2$ & $53 \pm 2$ & $34 \pm 2$ & $31 \pm 2$ & $47 \pm 2$ \\
\hline $7 / 31$ & $25 \pm 2$ & $21 \pm 2$ & $40 \pm 2$ & $28 \pm 2$ & $35 \pm 2$ & $M \& 046 \pm 2$ & $36 \pm 2$ & $28 \pm 2$ & $35 \pm 2$ \\
\hline$B / 7$ & $28 \pm 2$ & $20 \pm 2$ & $34 \pm 2$ & $26 \pm 2$ & $27 \pm 2$ & $39 \pm 2$ & $26 \pm 2$ & $28 \pm 2$ & $32 \pm 2$ \\
\hline $8 / 14$ & $12 \pm 2$ & $22 \pm 2$ & $42 \pm 2$ & $29 \pm 2$ & $31 \pm 2$ & $43 \pm 2$ & $39 \pm 3$ & $29 \pm 3$ & $39 \pm 2$ \\
\hline $8 / 21$ & $26 \pm 3$ & $23 \pm 2$ & $37 \pm 2$ & $30 \pm 2$ & $30 \pm 2$ & $45 \pm 2$ & NS & $24 \pm 2$ & $39 \pm 2$ \\
\hline $8 / 2 B$ & $24 \pm 3$ & $21 \pm 2$ & $38 \pm 2$ & $28 \pm 2$ & $25 \pm 2$ & $43 \pm 2$ & $29 \pm 2$ & $26 \pm 3$ & $40 \pm 2$ \\
\hline $9 / 4$ & NS & $27 \pm 2$ & $58 \pm 2$ & $42 \pm 3$ & $41 \pm 3$ & $73 \pm 2$ & $40 \pm 3$ & $42 \pm 3$ & $61 \pm 2$ \\
\hline $9 / 11$ & $41 \pm 5$ & $27 \pm 2$ & $43 \pm 2$ & $41 \pm 3$ & $38 \pm 3$ & $51 \pm 2$ & $45 \pm 3$ & $34 \pm 3$ & $48 \pm 2$ \\
\hline $9 / 18$ & $20 \pm 4$ & $20 \pm 2$ & $40 \pm 2$ & $24 \pm 2$ & $25 \pm 2$ & $41 \pm 2$ & $23 \pm 3$ & $25 \pm 2$ & $40 \pm 2$ \\
\hline $9 / 25$ & $21 \pm 2$ & $17 \pm 2$ & $29 \pm 2$ & $24 \pm 2$ & $20 \pm 2$ & $32 \pm 2$ & $20 \pm 2$ & $21 \pm 2$ & NS \\
\hline $10 / 2$ & $21 \pm 2$ & $22 \pm 2$ & $39 \pm 2$ & $28 \pm 2$ & $32 \pm 2$ & $43 \pm 2$ & $26 \pm 2$ & $30 \pm 2$ & $39 \pm 2$ \\
\hline 1019 & $20 \pm 2$ & $16 \pm 2$ & $26 \pm 2$ & $20 \pm 2$ & $20 \pm 2$ & $27 \pm 2$ & $13 \pm 1$ & $22 \pm 2$ & $27 \pm 2$ \\
\hline $10 / 16$ & $22 \pm 2$ & $18 \pm 2$ & $35 \pm 2$ & $32 \pm 2$ & $29 \pm 2$ & $44 \pm 2$ & $31 \pm 2$ & $23 \pm 2$ & $39 \pm 2$ \\
\hline $10 / 23$ & $17 \pm 2$ & $13 \pm 2$ & $28 \pm 2$ & $20 \pm 2$ & $18 \pm 2$ & $30 \pm 2$ & $19 \pm 2$ & $19 \pm 3$ & $28 \pm 2$ \\
\hline 10130 & $40 \pm 5$ & $37 \pm 3$ & $52 \pm 2$ & $48 \pm 3$ & $42 \pm 3$ & $68 \pm 2$ & $45 \pm 2$ & $45 \pm 3$ & $55 \pm 2$ \\
\hline 1116 & $26 \pm 2$ & $29 \pm 3$ & $47 \pm 2$ & $34 \pm 2$ & $32 \pm 3$ & $59 \pm 2$ & $30 \pm 2$ & $35 \pm 3$ & $47 \pm 2$ \\
\hline $11 / 13$ & $14 \pm 2$ & $16 \pm 2$ & $22 \pm 1$ & $21 \pm 2$ & $24 \pm 2$ & $41 \pm 2$ & $20 \pm 2$ & $19 \pm 2$ & $31 \pm 2$ \\
\hline $11 / 20$ & $24 \pm 2$ & $25 \pm 2$ & $32 \pm 2$ & $45 \pm 2$ & $40 \pm 3$ & $64 \pm 2$ & $38 \pm 2$ & $33 \pm 3$ & $50 \pm 2$ \\
\hline $11 / 26$ & $12 \pm 1$ & $11 \pm 2$ & $13 \pm 1$ & $16 \pm 2$ & $16 \pm 3$ & $15 \pm 1$ & $17 \pm 2$ & $11 \pm 3$ & $13 \pm 1$ \\
\hline $12 / 4$ & $15 \pm 1$ & $17 \pm 2$ & $21 \pm 1$ & $21 \pm 2$ & $20 \pm 2$ & $32 \pm 1$ & $21 \pm 2$ & $22 \pm 2$ & $26 \pm 1$ \\
\hline $12 / 11$ & $8 \pm 1$ & $8 \pm 2$ & $12 \pm 1$ & $14 \pm 1$ & $10 \pm 2$ & $24 \pm 1$ & $12 \pm 1$ & $9 \pm 2$ & $19 \pm 1$ \\
\hline $12 / 18$ & $25 \pm 2$ & $19 \pm 2$ & $40 \pm 2$ & $31 \pm 2$ & $23 \pm 2$ & $63 \pm 2$ & $29 \pm 2$ & $15 \pm 2$ & $36 \pm 2$ \\
\hline $12 / 24$ & $33 \pm 2$ & $30 \pm 3$ & $56 \pm 2$ & $25 \pm 2$ & $30 \pm 3$ & $63 \pm 2$ & $35 \pm 2$ & $25 \pm 3$ & $48 \pm 2$ \\
\hline $12 / 31$ & $27 \pm 2$ & NS & $39 \pm 2$ & $40 \pm 2$ & NS & $67 \pm 2$ & $34 \pm 3$ & NS & $44 \pm 2$ \\
\hline
\end{tabular}


Table 9-9. Comparison of Foundation and State of Idaho Water Monitoring Results (1998)

\begin{tabular}{|c|c|c|c|c|c|c|c|}
\hline \multirow{4}{*}{$\begin{array}{l}\text { Location } \\
\text { Minidoka } \\
\text { (Drinking } \\
\text { Water) }\end{array}$} & \multirow[b]{2}{*}{ Date } & \multicolumn{2}{|c|}{$\begin{array}{c}\text { Gross Alpha } \\
\left(10^{-9} \mu \mathrm{Ci} / \mathrm{mL}\right)\end{array}$} & \multicolumn{2}{|c|}{$\begin{array}{c}\text { Gross Beta } \\
\left(10^{-9} \mu \mathrm{Ci} / \mathrm{mL}\right)\end{array}$} & \multicolumn{2}{|c|}{$\begin{array}{c}\text { Trifium } \\
\left(10^{-9} \mu \mathrm{Ci} / \mathrm{mL}\right) \\
\end{array}$} \\
\hline & & Foundation & State & Foundation & State & Foundation & State \\
\hline & $05 / 98$ & $O \pm 1$ & $2 \pm 1$ & $5 \pm 2$ & $2 \pm 1$ & $-65 \pm 99$ & $40 \pm 100$ \\
\hline & $11 / 98$ & $0 \pm 1$ & $1 \pm 1$ & $4 \pm 2$ & $2 \pm 1$ & $-50 \pm 95$ & $60 \pm 90$ \\
\hline $\begin{array}{l}\text { Shoshone } \\
\text { (Drinking }\end{array}$ & $05 / 98$ & $0 \pm 1$ & $3 \pm 1$ & $3 \pm 2$ & $2 \pm 1$ & $21 \pm 101$ & $70 \pm 150$ \\
\hline Water) & $11 / 98$ & $O \pm 1$ & $0 \pm 2$ & $4 \pm 2$ & $2 \pm 1$ & $13 \pm 96$ & $50 \pm 90$ \\
\hline $\begin{array}{l}\text { Bill Jones } \\
\text { Hatchery }\end{array}$ & $05 / 98$ & $0 \pm 1$ & $7 \pm 2$ & $3 \pm 2$ & $2 \pm 1$ & $-13 \pm 100$ & $40 \pm 90$ \\
\hline $\begin{array}{l}\text { (Surface } \\
\text { Water) }\end{array}$ & $11 / 98$ & $O \pm 1$ & $2 \pm 1$ & $5 \pm 2$ & $1 \pm 1$ & $-38 \pm 96$ & $135 \pm 95$ \\
\hline $\begin{array}{l}\text { Clear Springs } \\
\text { (Surface }\end{array}$ & $05 / 98$ & $O \pm 1$ & $1 \pm 2$ & $4 \pm 2$ & $2 \pm 1$ & $25 \pm 101$ & $50 \pm 90$ \\
\hline Water) & $11 / 98$ & $O \pm 1$ & $2 \pm 1$ & $6 \pm 2$ & $2 \pm 1$ & $-103 \pm 95$ & $210 \pm 100$ \\
\hline $\begin{array}{l}\text { Alpheus Spring } \\
\text { (Surface }\end{array}$ & $05 / 98$ & $O \pm 1$ & $11 \pm 2$ & $7 \pm 2$ & $5 \pm 1$ & $2 \pm 100$ & $50 \pm 90$ \\
\hline Water) & $11 / 98$ & $1 \pm 1$ & $3 \pm 2$ & $9 \pm 2$ & $4 \pm 1$ & $40 \pm 96$ & $130 \pm 90$ \\
\hline
\end{tabular}




\section{APPENDIX A ENVIRONMENTAL STANDARDS AND REGULATIONS}

The following environmental standards and regulations are applicable, in whole or in part, on the INEEL or at the INEEL boundary.

U.S. Environmental Protection Agency, "National Primary and Secondary Ambient Air Quality Standards," 40 CFR 50, 1998.

U.S. Environmental Protection Agency, "National Emission Standards for Hazardous Air Pollutants," 40 CFR 61, 1998.

U.S. Environmental Protection Agency, "National Pollutant Discharge Elimination System," 40 CFR 122, 1998.

U.S. Environmental Protection Agency, "National Interim Primary Drinking Water Regulations," 40 CFR 141, 1998.

U.S. Environmental Protection Agency, "Hazardous Waste Management System: General," 40 CFR 260, 1998.

U.S. Environmental Protection Agency, "Identifying and Listing of Hazardous Wastes," 40 CFR 261, 1998.

U.S. Environmental Protection Agency, "Standards Applicable to Generators of Hazardous Waste," 40 CFR 262, 1998.

U.S. Environmental Protection Agency, "Standards Applicable to Transporters of Hazardous Waste," 40 CFR 263, 1998.

U.S. Environmental Protection Agency, "Standards for Owners and Operators of Hazardous Waste Treatment, Storage and Disposal Facilities," 40 CFR 264, 1998.

U.S. Environmental Protection Agency, "Interim Status Standards for Owners and Operators of Hazardous Waste Treatment, Storage and Disposal Facilities," 40 CFR 265, 1998.
U.S. Environmental Protection Agency, "Interim Standards for Owners and Operators of New Hazardous Waste Land Disposal Facilities," 40 CFR 267, 1998.

Department of Health and Welfare, State of Idaho, "Rules and Regulations for the Control of Air Pollution in Idaho," 1972, as amended through May 1990.

Department of Health and Welfare, State of Idaho, "Idaho Regulations for Public Drinking Water Systems," 16.01.8000-16.01.8999, October 1993.

The Derived Concentration Guides (DCGs) are based on the DOE standard [Reference A-1] and have been calculated using DOE models and parameters for internal [Reference A-2] and external [Reference A-3] exposure. These are shown in Table A-1. The most restrictive guide is listed when there is a difference between the soluble and insoluble chemical forms. The DCGs consider only the inhalation of air, the ingestion of water, and submersion in air. The principal standards and guides for release of radionuclides at the INEEL are those of DOE Order 5400.5, entitied "Radiation Protection of the Public and the Environment." The DOE standard is shown in Table A-2 along with the EPA standard for protection of the public, airborne pathway only.

Ambient air quality standards are shown in Table A-3. Water quality standards are dependent on the type of drinking water system sampled. Table A-4 is a partial list of maximum contaminant levels set by the EPA for public community drinking water systems in 40 CFR 141. 
Table A-1. Derived Concentration Guides for Radiation Protection

\begin{tabular}{|c|c|c|c|c|c|}
\hline \multicolumn{3}{|c|}{$\begin{array}{l}\text { Derived Concentration Guide }{ }^{\circ} \\
(\mu \mathrm{Ci} / \mathrm{mL})\end{array}$} & \multicolumn{3}{|c|}{$\begin{array}{l}\text { Derived Concentration Guide }{ }^{a} \\
(\mu \mathrm{Ci} / \mathrm{mL})\end{array}$} \\
\hline Radionuclide & In Air & In Water & Radionuclide & In Air & In Water \\
\hline$\overline{\text { Gross Alpha }}{ }^{b}$ & $2 \times 10^{-14}$ & $3 \times 10^{-8}$ & ${ }^{129} 1$ & $7 \times 10^{-11}$ & $\overline{5 \times 10^{7}}$ \\
\hline Gross Beta & $3 \times 10^{-12}$ & $1 \times 10^{-7}$ & ${ }^{131}$ & $4 \times 10^{-10}$ & $3 \times 10^{6}$ \\
\hline${ }^{3} \mathrm{H}$ & $1 \times 10^{-7}$ & $2 \times 10^{-3}$ & 132. & $4 \times 10^{-8}$ & $2 \times 10^{-4}$ \\
\hline${ }^{14} \mathrm{C}$ & $5 \times 10^{-7}$ & $7 \times 10^{-5}$ & 1331 & $2 \times 10^{-9}$ & $1 \times 10^{-5}$ \\
\hline${ }^{24} \mathrm{Na}{ }^{d}$ & $4 \times 10^{-9}$ & $1 \times 10^{-4}$ & 135 & $1 \times 10^{-8}$ & $7 \times 10^{-5}$ \\
\hline${ }^{41} \mathrm{Ar}$ & $1 \times 10^{-8}$ & - & ${ }^{131 m} \times e$ & $2 \times 10^{-6}$ & - \\
\hline${ }^{51} \mathrm{Cr}$ & $5 \times 10^{-8}$ & $1 \times 10^{-3}$ & ${ }^{133} \mathrm{Xe}$ & $5 \times 10^{-7}$ & - \\
\hline${ }^{54} \mathrm{Mn}$ & $2 \times 10^{-9}$ & $5 \times 10^{-5}$ & ${ }^{133 m} \mathrm{Xe}$ & $6 \times 10^{-7}$ & - \\
\hline${ }^{58} \mathrm{Co}$ & $2 \times 10^{9}$ & $4 \times 10^{-5}$ & ${ }^{135} \times e$ & $8 \times 10^{-8}$ & - \\
\hline${ }^{60} \mathrm{Co}$ & $8 \times 10^{-11}$ & $5 \times 10^{-6}$ & ${ }^{13 \mathrm{bm}} \mathrm{Xe}$ & $5 \times 10^{-8}$ & - \\
\hline${ }^{6} \mathrm{Zn}$ & $6 \times 10^{-10}$ & $9 \times 10^{-6}$ & ${ }^{138} X_{e}$ & $2 \times 10^{-8}$ & - \\
\hline${ }^{8} \mathrm{Kr}$ & $3 \times 10^{-6}$ & - & ${ }^{134} \mathrm{C}_{5}$ & $2 \times 10^{10}$ & $2 \times 10^{-6}$ \\
\hline${ }^{85 m} \mathrm{Kr}$ & $1 \times 10^{-7}$ & - & ${ }^{137} \mathrm{Cs}$ & $4 \times 10^{-10}$ & $3 \times 10^{-6}$ \\
\hline${ }^{87} \mathrm{Kr}$ & $2 \times 10^{-8}$ & - & ${ }^{138} \mathrm{Cs}$ & $1 \times 10^{-7}$ & $9 \times 10^{-4}$ \\
\hline${ }^{88} \mathrm{Kr}$ & $9 \times 10^{-9}$ & - & ${ }^{139} \mathrm{Ba}$ & $7 \times 10^{8}$ & $3 \times 10^{-4}$ \\
\hline $88 \mathrm{Rb}$ & $3 \times 10^{-8}$ & $8 \times 10^{-4}$ & ${ }^{140} \mathrm{Ba}$ & $3 \times 10^{-9}$ & $2 \times 10^{-5}$ \\
\hline${ }^{89} \mathrm{Rb}$ & $3 \times 10^{-7}$ & $2 \times 10^{-3}$ & ${ }^{141} \mathrm{Ce}$ & $1 \times 10^{-9}$ & $5 \times 10^{-5}$ \\
\hline${ }^{89} \mathrm{Sr}$ & $3 \times 10^{-10}$ & $2 \times 10^{-5}$ & ${ }^{144} \mathrm{Ce}$ & $3 \times 10^{-11}$ & $7 \times 10^{-6}$ \\
\hline${ }^{90} \mathrm{Sr}$ & $9 \times 10^{-12}$ & $1 \times 10^{-6}$ & ${ }^{238} \mathrm{Pu}$ & $3 \times 10^{-14}$ & $4 \times 10^{-8}$ \\
\hline $9 \operatorname{lm} Y$ & $4 \times 10^{-7}$ & $4 \times 10^{-3}$ & ${ }^{239} \mathrm{Pu}$ & $2 \times 10^{-14}$ & $3 \times 10^{-8}$ \\
\hline${ }^{9} \mathrm{Zr}$ & $6 \times 10^{-10}$ & $4 \times 10^{-5}$ & ${ }^{240} \mathrm{Pu}$ & $2 \times 10^{-14}$ & $3 \times 10^{-8}$ \\
\hline${ }^{99 m} T C$ & $4 \times 10^{-7}$ & $2 \times 10^{-3}$ & ${ }^{241} \mathrm{Am}$ & $2 \times 10^{-14}$ & $3 \times 10^{-8}$ \\
\hline${ }^{103} \mathrm{Ru}$ & $2 \times 10^{-9}$ & $5 \times 10^{-5}$ & & & \\
\hline${ }^{106} \mathrm{Ru}$ & $3 \times 10^{-11}$ & $6 \times 10^{6}$ & & & \\
\hline${ }^{125} \mathrm{Sb}$ & $1 \times 10^{-9}$ & $5 \times 10^{-5}$ & & & \\
\hline \multicolumn{6}{|c|}{$\begin{array}{l}\text { Derived concentration guides (DCGS) are from DOE Order } 5400.5 \text { and are based on an effective dose equivalent of } 100 \\
\text { mrem/yr. } \\
\text { Based on }{ }^{241} \mathrm{Am} \text {, }{ }^{239} \mathrm{Pu} \text {, and }{ }^{240} \mathrm{Pu} \text {. } \\
\text { Based on the most restrictive beta emitter }\left({ }^{228} \mathrm{Ra}\right) \text {. } \\
\text { B Submersion in a cloud of gas is more restrictive than the inhalation pathway. }\end{array}$} \\
\hline
\end{tabular}




\section{Table A-2. Radiation Standards for Protection of the Public in the Vicinity of DOE Facilities}

\begin{tabular}{|c|c|c|}
\hline & \multicolumn{2}{|c|}{ Effective Dose Equivalent } \\
\hline & mrem/yr & $\underline{m S v / y r}$ \\
\hline $\begin{array}{l}\text { DOE Standard for routine DOE activities } \\
\text { (all pathways) }\end{array}$ & 100 & 1 \\
\hline $\begin{array}{l}\text { EPA Standard for site operations } \\
\text { (airborne pathway only) }\end{array}$ & 10 & 0.1 \\
\hline $\begin{array}{l}\text { The effective dose equivalent for any member of the public from all } \\
\text { release of naturally-occurring radionuclides shall not exceed this val } \\
\text { operations and does not include accidental or unplanned releases. }\end{array}$ & $\begin{array}{l}\text { operations } \\
\text { ne operations }\end{array}$ & $\begin{array}{l}\text { activities } \\
\text { planned }\end{array}$ \\
\hline
\end{tabular}

Table A-3. EPA Ambient Air Quality Standards

\begin{tabular}{|c|c|c|c|}
\hline Pollutant & Type of Standard & Sampling Period & EPA $\left(\mu \mathrm{g} / \mathrm{m}^{3}\right)^{b}$ \\
\hline \multirow[t]{3}{*}{$\mathrm{SO}_{2}$} & $s$ & 3-hour average & 1300 \\
\hline & $P$ & 24-hour average & 365 \\
\hline & $P$ & Annual average & 80 \\
\hline \multirow[t]{2}{*}{$\mathrm{NO}_{2}$} & S\&P & Annual average & 100 \\
\hline & $s$ & 24-hour average & 150 \\
\hline Total Particulates ${ }^{c}$ & S\&P & Annual average & 50 \\
\hline \multicolumn{4}{|c|}{$\begin{array}{l}\text { "National primary (P) ambient air quality standards define levels of air quality to protect the public health. Secondary (S } \\
\text { ambient air quality standards define levels of air quality to protect the public welfare from any known or anticipated } \\
\text { adverse effects of a pollutant. } \\
\text { "The State of ldaho has adopted these same ambient air quality standards. } \\
\text { "The primary and secondary standard to the annual average applies only to "particulates with an aerodynamic diameter } \\
\text { less than or equal to a nominal } 10 \text { micrometers." }\end{array}$} \\
\hline
\end{tabular}


Table A-4. EPA Maximum Contaminant Levels for Nontransient Noncommunity Drinking Water Systems

\begin{tabular}{ll}
\hline Gross alpha & $1.5 \times 10^{-8} \mu \mathrm{Cl} / \mathrm{mL}$ \\
Gross beta & $5.0 \times 10^{-8} \mu \mathrm{Ci} / \mathrm{mL}$ \\
Human-made radionuclides & Concentrations resulting in 4 mrem total \\
& body or organ dose equivalent \\
Nitrate (as $\mathrm{N}$ ) & $10 \mathrm{mg} / \mathrm{L}$ \\
Fluoride & $4 \mathrm{mg} / \mathrm{L}$ \\
Trihalomethanes (Chloroform) & $0.1 \mathrm{mg} / \mathrm{L}$ \\
Carbon Tetrachloride & $0.005 \mathrm{mg} / \mathrm{L}$ \\
Tetrachloroethylene & $0.005 \mathrm{mg} / \mathrm{L}$ \\
Toluene & $1.0 \mathrm{mg} / \mathrm{L}$ \\
1,1,1-trichloroethane & $0.2 \mathrm{mg} / \mathrm{L}$ \\
Trichloroethylene & $0.005 \mathrm{mg} / \mathrm{L}$ \\
Arsenic & $0.05 \mathrm{mg} / \mathrm{L}$ \\
Barium & $2 \mathrm{mg} / \mathrm{L}$ \\
Cadmium & $0.005 \mathrm{mg} / \mathrm{L}$ \\
Chromium & $0.1 \mathrm{mg} / \mathrm{L}$ \\
Lead & $0.05 \mathrm{mg} / \mathrm{L}$ \\
Mercury & $0.002 \mathrm{mg} / \mathrm{L}$ \\
Selenium & $0.05 \mathrm{mg} / \mathrm{L}$ \\
Silver & $0.05 \mathrm{mg} / \mathrm{L}$ \\
\hline
\end{tabular}




\section{APPENDIX B STATISTICAL METHODS USED FOR THE ENVIRONMENTAL SURVEILLANCE PROGRAM}

Relatively simple statistical procedures are used to analyze the data from the INEEL environmental surveillance program. Environmental surveillance program personnel initially review field collection information and analytical results to determine whether there are identifiable errors that would invalidate or limit the use of the results. Examples of these might be power outages at air sampler locations, torn membrane filters, or evidence of laboratory cross-contamination. Data that pass this initial screening are then evaluated for statistical significance with respect to laboratory analytical uncertainties, sample locations, reported releases from INEEL operations, meteorological data, and worldwide events that might conceivably have an effect on the INEEL environment.

For radiological data, individual analytical results are presented in this report with plus or minus ( \pm ) two analytical standard deviations (2s), where all analytical uncertainties have been estimated, and " $s$ " is an estimate of the population standard deviation " $\sigma$." Many of the results were less than or equal to 2 s (and, in fact, some were negative), which means that they were below the minimum detectable concentration. For example, in gamma spectrometric analyses, a given radionuclide is not considered detected unless the net count in the peak is greater than three times its estimated analytical uncertainty (3s). If the result lies in the range of two to three times its estimated analytical uncertainty ( $2 \mathrm{~s}$ to $3 \mathrm{~s}$ ), and assuming that the result belongs to a Gaussian distribution, detection of the material by the analysis may be questionable because of statistical variations within the group of samples. If the result exceeds 3s, there is confidence that the material was detected (or, that the radionuclide was present in the sample).

A deliberate search for specific nuclides can be made and results reported, but such results might include negative values or small positive values where the result is less than or equal to $2 \mathrm{~s}$. Analyses with results in the questionable range ( $2 s$ to $3 s$ ) are published in this report with the understanding that there is some doubt as to whether the material was actually present.

There are many factors that can influence the result to some degree, and these factors are considered and included in the methods used to determine the estimated uncertainty of the measurement. Uncertainties in measurements near the minimum detectable concentration are primarily caused by counting statistics. For low concentrations near the minimum detectable concentration, the uncertainty in the measurement is nearly equal to the measurement itself, and the lower limit of the range of the measurement approaches "zero." Such a result might not be very reliable because the uncertainty is only an estimate and the actual probability distribution of the results is not usually known. In reality, the material being measured may not actually be present in the sample. Therefore, when analytical results show a measurement very near the minimum detectable concentration, statistical tools, meteorological data, and Site release information are all considered when interpreting and evaluating the results.

Arithmetic means were calculated using actual assay results, regardless of their being above or below the minimum detectable concentration. The uncertainty of the mean, or the 95\% confidence interval, was determined by multiplying the standard deviation of the mean (also called the standard error of the mean) or $\mathrm{s} /(\mathrm{n})^{1 / 2}$ by the $\mathrm{t}_{(0.05)}$ statistic. Means for which the $95 \%$ confidence interval does not include zero were assumed to indicate detectable amounts of activity. In situations where the analytical results of a group of samples are near the minimum detectable concentration, the 95\% confidence interval for the mean may not include zero and thus appears to be statistically 
significant even though, on the basis of the $2 \mathrm{~s}$ to 3s criterion, it is doubtful that any individual sample contained detectable radioactivity.

Geometric means were calculated by summing the natural logarithms (In) of the positive analytical results, dividing by the number of samples ( $n$ ), and then transforming the quotient. If the result was either a negative number or a zero, the In of the smallest positive, nonzero measurement in the group was used. The 95\% confidence interval was determined by multiplying the standard deviation of the geometric mean by the $t_{(0.05)}$ statistic and then transforming the result. The actual interval is determined by dividing the transformed mean by the transformed $95 \%$ confidence interval term for the lower limit, then multiplying the mean by the confidence interval term for the upper limit.

Unpaired t-tests were used to determine whether the annual means for the INEEL or boundary stations were greater than the annual means for the distant stations. All statistical tests used a level of significance of 5\% $(\alpha=0.05)$. 


\section{REFERENCES}

P-1 National Council on Radiation Protection and Measurements, lonizing Radiation Exposure of the Population of the United States, NCRP Report No. 93, September 1, 1987.

P-2 U.S. Department of Energy Order 5400.1, General Environmental Protection Program, November 9, 1988.

1-1 Department of Energy National Environmental Research Parks, DOE/ER-0615P, July 1994.

1-2 Clawson, K.L., Start, G.E., and Ricks, N.R. U.S. Department of Commerce, NOAA, ERL, ARL, FRD, Climatography of the Idaho National Engineering Laboratory, 2nd Edition, DOE/ID-12118, $2^{\text {nd }}$ edition, December 1989.

1-3 Anderson, J.E., Ruppel, K.T., Glennon, J.M., Holte, K.E., and Rope, R.C. Plant Communities, Ethnoecology, and Flora of the Idaho National Engineering Laboratory, ESRF-005, June 1996.

1-4 Arthur, W.J., Connelly, J.W., Halford, D.K., and Reynolds, T.D. Vertebrates of the Idaho National Engineering Laboratory, DOE/ID-12099, July 1984.

1-5 Idaho National Engineering Laboratory Comprehensive Facility \& Land Use Plan, DOE/ID-10514,December 1997.

1-6 INEEL Overview, http://www.inel.gov/about/overview/overview.html

1-7 Idaho National Environmental Research Park, INEL BP499-R1091-1M-T, no date.

1-8 Lindholm, G.F. Summary of the Snake River Plain Regional Aquifer - System Analysis in Idaho and Eastern Oregon, U.S. Geological Survey Professional Paper 1408-A, 1996.

1-9 The Site, the Plain, the Aquifer, and the Magic Valley (Part One of Four), Foundation Focus, Volume 3, Issue 3, Environmental Science and Research Foundation, October 1996.

1-10 U.S. Department of Energy Idaho Operations Office 1998 Annual Report, No Date.

1-11 Idaho State Department of Transportation. Idaho 1996 Official Highway Map

2-1 VanHorn, R.L., Hampton, N.L., and Morris, R.C. Guidance Manual for Conducting Screening Level Ecological Risk Assessments at the INEL, INEL-95/0190, June 1995. 


\section{REFERENCES (Cont.)}

2-2 DOE, Natural Resource Trusteeship and Ecological Evaluation for Environmental Restoration at Department of Energy Facilities, DOE/EH-0192, June 1991.

2-3 U.S. Environmental Protection Agency, 40 CRF 261.4, Treatability Studies, 1996.

2-4 Blew, R.D. and Weigmann, D. Environmental Science and Research Foundation Annual Technical Report to DOE-ID, Calendar Year 1998, ESRF-033.

3-1 Agreement to Resolve Disputes, Docket No. 1088-06-29-120, March 18, 1997.

3-2 Remedial Design/Remedial Action Scope of Work and Remedial Design Work Plan: Operable Unit 7-10 (Pit 9 Project Interim Action), October 1997, Revision 2, Document No. INEL-94/0110.

3-3 Over 2,000 Unexploded Ordnance Removed From the Idaho National Engineering and Environmental Laboratory (INEEL), 97-561-1-28

3-4 Defense Nuclear Facilities Safety Board. Recommendation 94-1: Improved Schedule for Remediation in Defense Nuclear Facilities Complex, May 26, 1994.

3-5 U.S. Environmental Protection Agency, Compilation of Air Pollutant Emission Factors, AP-42, Part A, August 1982; pp. 1.3-2.

3-6 "Final National Pollutant Discharge Elimination System Storm Water Multi-Sector General Permit for Industrial Activities; Notice, Federal Register, Vol. 60, No. 189, p. 50826, Sept. 29, 1995.

State of Idaho INEEL Oversight Program Environmental Surveillance Report 1997.

4-1 U.S. Environmental Protection Agency, Environmental Radiation Data Reports 7982, July 1994 - June 1995.

4-2 Yoder, R.C., et al. Confirmation of Conversion Factors Relating Exposure and DoseEquivalent Index Presented in ANSI N13.11, NUREG/CR-1057, PNL-3219: Pacific Northwest Laboratory, Richland, WA, 1979.

4-3 National Council on Radiation Protection and Measurements, Exposure of the Population in the United States and Canada from Natural Background Radiation, NCRP Report No. 94, December 30, 1987.

5-1 U.S. Environmental Protection Agency, National Primary and Secondary Ambient Air Quality Standards for Particulate Matter, 40 CFR 50.6, 1996. 


\section{REFERENCES (Cont.)}

U.S. Environmental Protection Agency, National Primary Ambient Air Quality Standards for Nitrogen Oxides, 40 CFR 50.4 and National Secondary Ambient Air Quality Standards for Sulfur Oxides, 40 CFR 50.5, 1996.

Annual Report, Aerosol Collection and Compositional Analysis for IMPROVE, July 1993 - June 1994, Air Quality Group, Crocker Nuclear Laboratory.

Bartholomay, R.C., Tucker, B.J., Ackerman, D.J., and Liszewski, M.J. Hydrologic Conditions and Distribution of Selected Radiochemical and Chemical Constituents in Water, Snake River Plain Aquifer, Idaho National Engineering Laboratory, Idaho, 1992 through 1995, U.S. Geological Survey, Water-Resources Investigation Report 97-4086, DOE/ID-22137, April 1997.

Bartholomay, R.C. Distribution of Selected Radiochemical and Chemical Constituents in Perched Ground Water, Idaho National Engineering Laboratory, Idaho, 1992-95, U.S. Geological Suney, Water-Resources Investigation Report 984026, DOE/ID-22145, February 1998. the Idaho National Engineering Laboratory, Idaho, 1992-95, U.S. Geological Survey, Open-File Report 98-51, DOE/ID-22146, June 1998.

6-4 Berenbrock, C. and Kjelstrom, L.C. Preliminary Water-Surface Elevations and Boundary of the 100-Year Peak Flow in the Big Lost River at the Idaho National Engineering and Environmental Laboratory, Idaho, U.S. Geological Survey, WaterResources Investigation Report 98-4065, DOE/ID-22148, 1998. Environmental Laboratory on the Water Quality of the Snake River Plain Aquifer in the Magic Valley Study, U.S. Geological Fact Sheet FS-052-98, 1998. Distribution Coefficients of Basalt Core Samples from the Idaho National Engineering and Environmental Laboratory, Idaho, U.S. Geological Survey, Water Resources Investigation Report 98-4256, DOE/ID-22153, December 1998. Distribution Coefficients of Surficial and Sedimentary Interbed Samples from the Idaho National Engineering and Environmental Laboratory, Idaho, U.S. Geological Survey, Water-Resources Investigation Report 98-4073, DOE/ID-22149, April 1998.

6-8 Bartholomay, R.C., Williams, L.M., and Campbell, L.J. Radiochemical and Chemical Constituents in Water from Selected Wells and Springs from the Southern Boundary 


\section{REFERENCES (Cont.)}

of the Idaho National Engineering and Environmental Laboratory to the Hagerman Area, Idaho, 1997, U.S. Geological Survey, Open-File Report Report 98-646, DOE/ID-22152, December 1998.

6-9 Orr, B.R., and Cecil, L.D. Hydrologic Conditions and Distribution of Selected Radiochemical and Chemical Constituents in Water, Snake River Plain Aquifer, Idaho National Engineering Laboratory, Idaho, 1986 through 1988, U.S. Geological Survey, Water-Resources Investigation Report 91-4047, DOE/ID-22096, 1991.

7-1 1998 INEEL National Emissions Standard for Hazardous Air Pollutants Radionuclides, DOE/ID-10342(98), June 1999.

7-2 Whicker, F.W. and Schultz, V. Radioecology: Nuclear Energy and the Environment, Volume 1, CRC Press, 1982.

7-3 Air Emissions Inventory for the Idaho National Engineering and Environmental Laboratory-1998 Emissions Report, DOE/ID-10594, September 1999.

7-4 U.S. Environmental Protection Agency, Toxicity Characteristic, 40 CFR 261.24, 1996.

8-1 Start, G.E., and Wendell, L.L. Regional Effluent Dispersion Calculations Considering Spatial and Temporal Meteorological Variations, NOAA Technical Memorandum ERL ARL-44, May 1974.

8-2 U.S. Department of Energy, Internal Dose Conversion Factors for Calculation of Dose to the Public, DOE/EH-0071, July 1988.

8-3 U.S. Department of Energy, External Dose Conversion Factors for Calculation of Dose to the Public, DOE/EH-0070, July 1988.

8-4 Hoff, D.L., Chew, E.W., and Rope, S.K. 1986 Environmental Monitoring Program Report for the Idaho National Engineering Laboratory Site, DOE/ID-12082(86), May 1987.

8-5 Hoff, D.L, Chew, E.W., and Rope, S.K. 1986 Environmental Monitoring Program for the Idaho National Engineering Laboratory Site, DOE/ID-12082(86), May 1987.

8-6 Chew, E.W., and Mitchell, R.G. 1987 Environmental Monitoring Program Report for the Idaho National Engineering Laboratory Site, DOE/ID-12082(87), May 1988.

8-7 Hoff, D.L., Mitchell, R.G., and Moore, Richard, 1988 Environmental Monitoring Program Report for the Idaho National Engineering Laboratory Site, DOE/ID12082(88), June 1989. 


\section{REFERENCES (Cont.)}

8-8 Halford, D.K., Markham, O.D., and White, G.C. Biological Elimination of Radioisotopes by Mallards Contaminated at a Liquid Radioactive Waste Disposal Area, Health Physics, 45, pp. 745-756.

8-9 Halford, D.K., Millard, J.B., and Markham, O.D. Radionuclide Concentrations in Waterfowl Using a Liquid Radioactive Disposal Area and the Potential Radiation Dose to Man, Health Physics, 40, February 1981, pp. 173-181.

8-10 Morris, R.C. The Implications of Lined Radioactive Waste Ponds for Waterfowl Contamination, Environmental Health Physics: Proceedings of the Twenty-sixth Midyear Topical Meeting of the Health Physics Society, R.L. Kathren et al. eds. pp. 147-155.

8-11 Markham, O.D. and Halford, D.K. Radionuclides in Mourning Doves Near a Nuclear Facility Complex in Southeastern Idaho, The Wilson Bulletin, 94, 2, June 1982, pp. 185-195.

8-12 Markham, O.D. and Halford, D.K. Effects of Decreased Effluents from Nuclear Fuel Reprocessing on Cs-137 Concentrations in Wildlife, Northwest Science, 59, 3, August 1985.

A-1 U.S. Department of Energy Order 5400.5, Radiation Protection of the Public and the Environment, January 7, 1993.

A-2 U.S. Department of Energy, Internal Dose Conversion Factors for Calculation of Dose to the Public, DOE/EH-0071, July 1988.

A-3 U.S. Department of Energy, External Dose Conversion Factors for Calculation of Dose to the Public, DOE/EH-0070, July 1988. 